\title{
50 Years of
}

Construction

Camps and

Single

Purpose

Towns in the

South

Fleur A J Kinsella

\section{A thesis}

submitted to the Victoria

University of Wellington

in fulfilment of the

requirements for the degree of

Master of Architecture

Victoria University of Wellington 


\section{ABSTRACT}

This thesis aims to ascertain lessons which can be learnt from the provision of accommodation at a progression of hydro projects in the south of New Zealand.

Seven case studies have been distilled from a wide range (and number) of existing documents and literature and collated in a manner unavailable in current literature in order to allow the researcher to compare and contrast them with a historical-interpretive methodology.

The analyses culminate in conclusions regarding site conditions, accommodation and layout designs and sense of community and the effect that these have had on past hydro project accommodations. This is done in order to provide a platform for further research into the development of guidelines for future large construction camps and single purpose towns within New Zealand, now that the designer and provider of the camps and towns which form the case studies in this thesis (the MoWD) has been abolished. 


\section{ACKNOWLEDGMENTS}

This thesis has been written over a particularly long period of time. I would like to thank my supervisor, Morten Gjerde, for his patience with seemingly endless suspensions of enrolment and the medical professionals who had the patience to allow me time to work on my thesis between their interventions.

My family and friends have also been incredibly supportive, for which I owe them a great deal of gratitude.

The staff at Wanaka Public Library, the National Archives in Dunedin and the Architecture and Design Library at Victoria University have all been of great assistance.

I would also like to thank Meridian Energy for the material which they readily supplied me with, despite the significant amount of time and effort which it must have taken them. 


\section{TABLE OF CONTENTS}

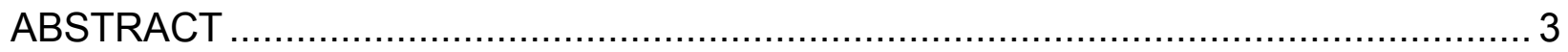

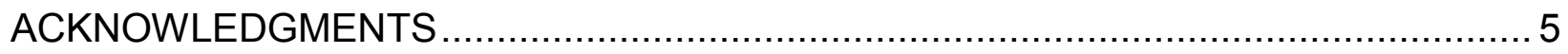

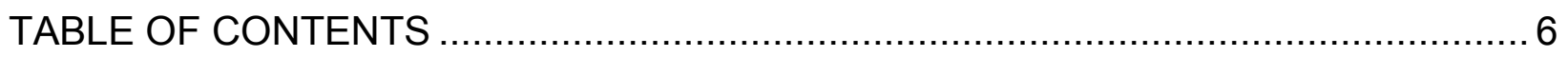

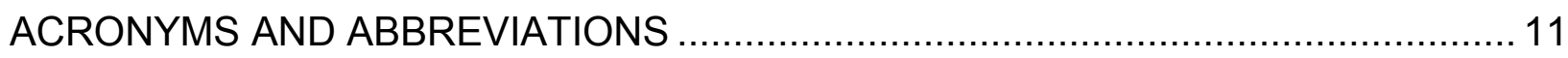

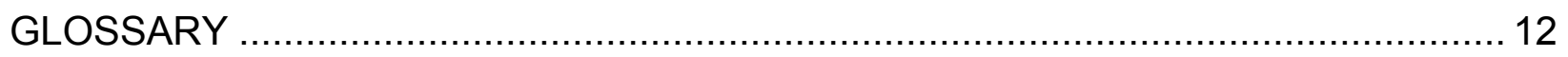

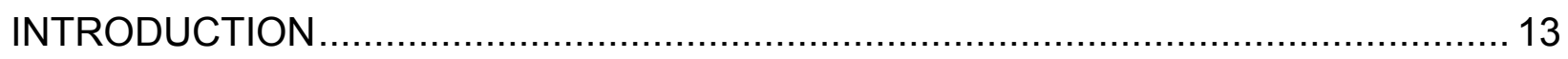

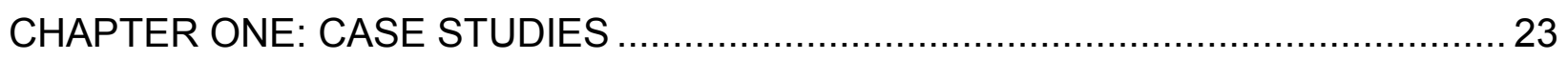

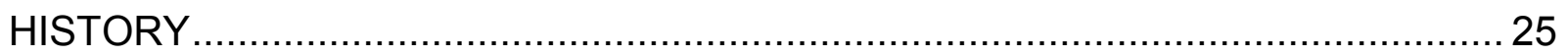

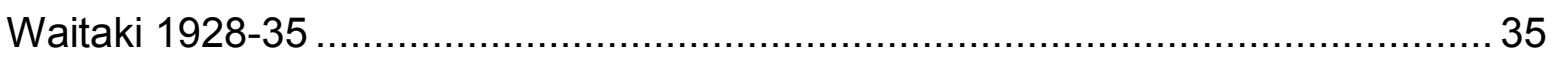

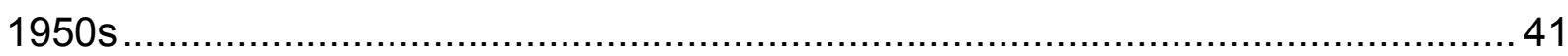

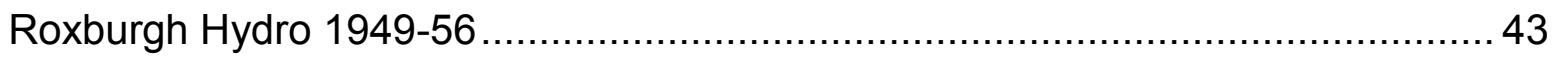

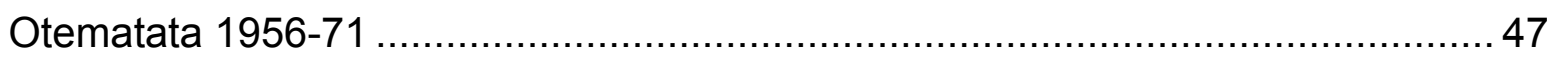

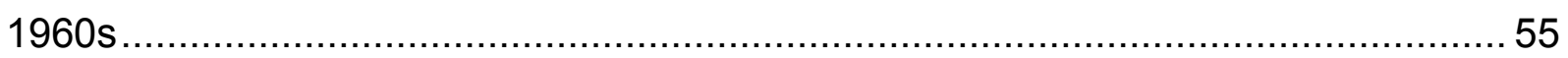

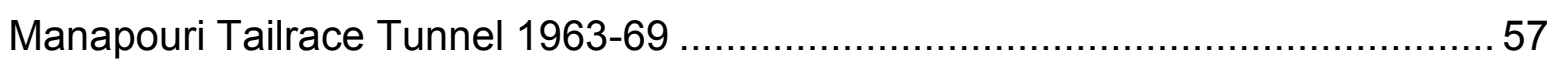

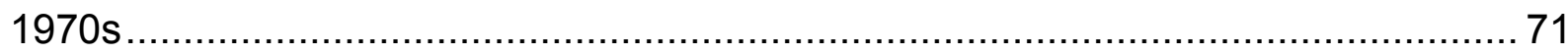

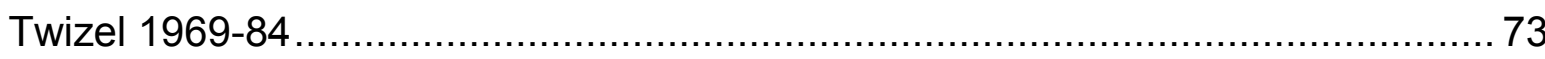

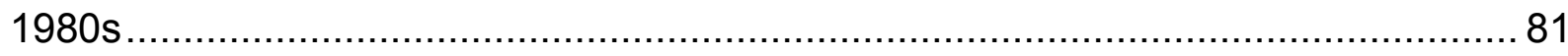

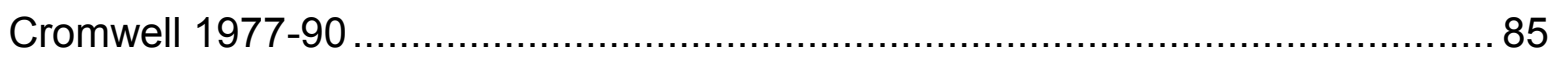

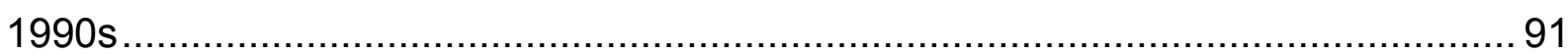

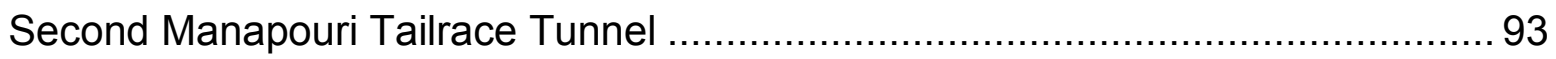

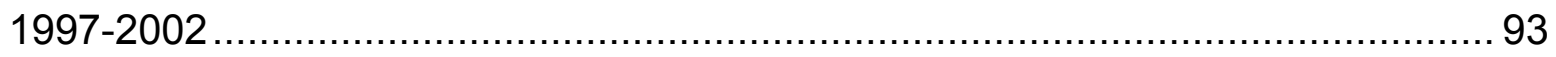

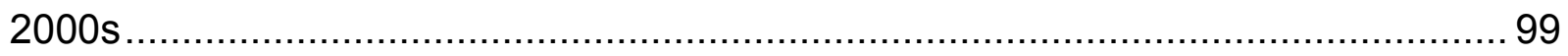

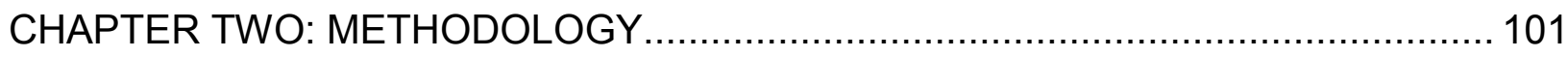

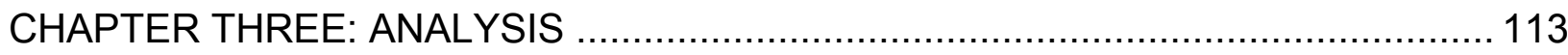

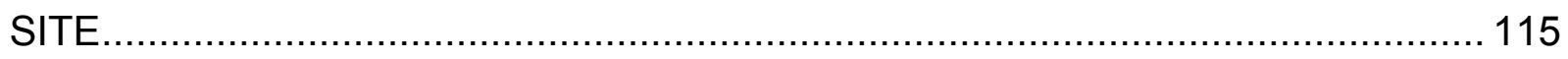

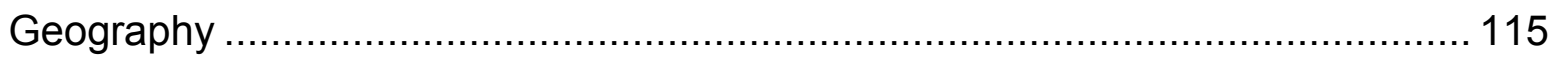

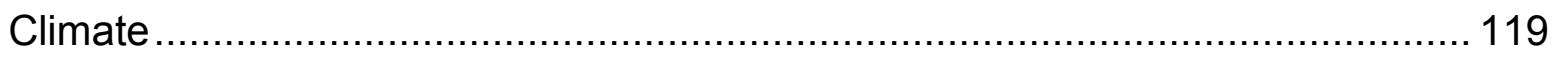

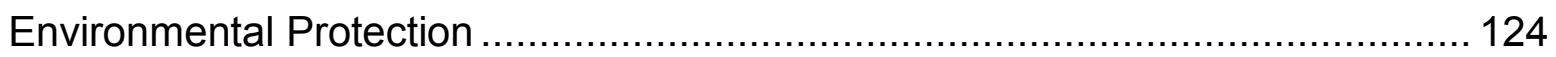

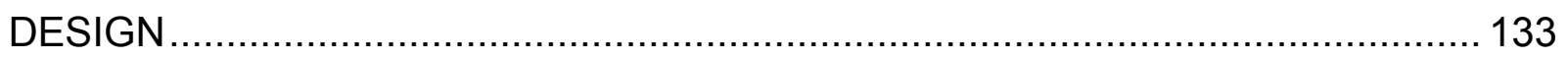

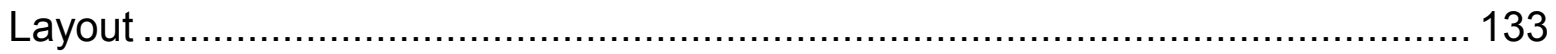

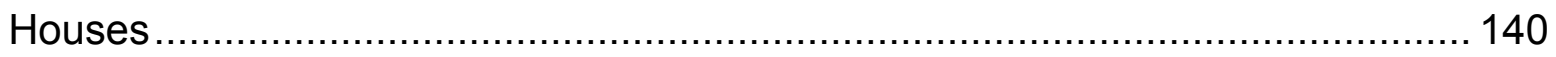

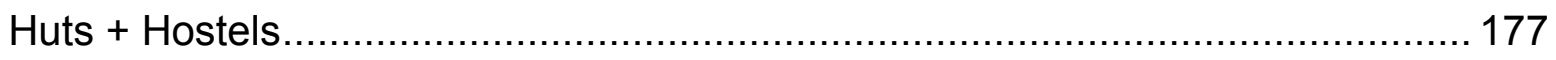

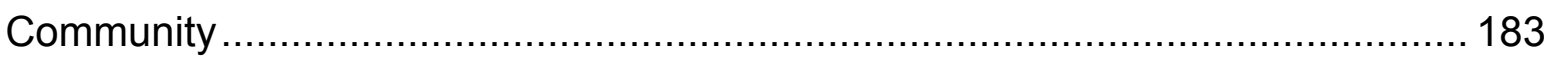




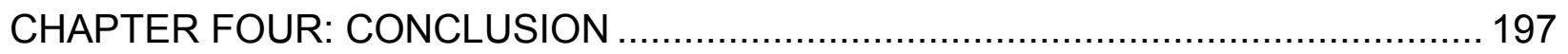

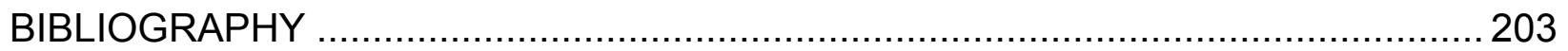

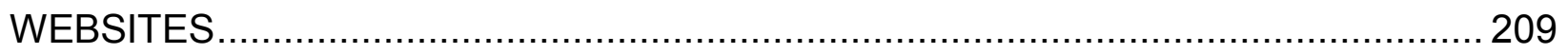

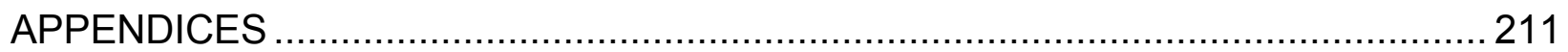

A: 1921 Public Works and Construction Workers Agreement............................. 213

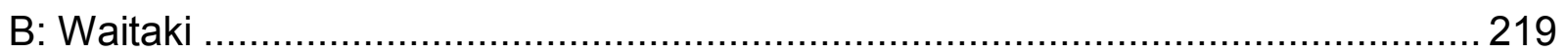

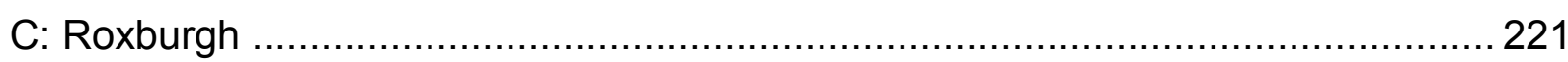

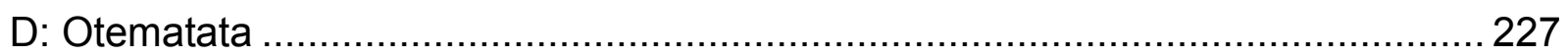

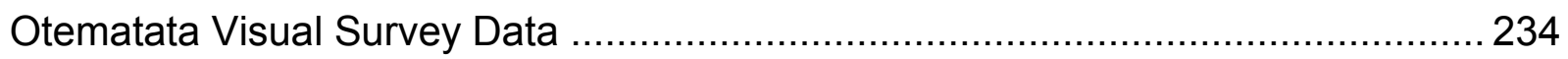

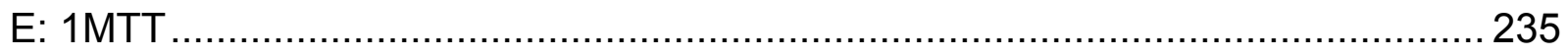

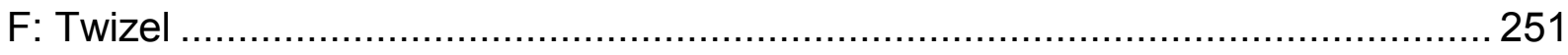

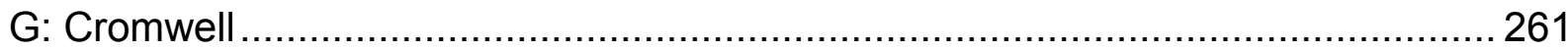

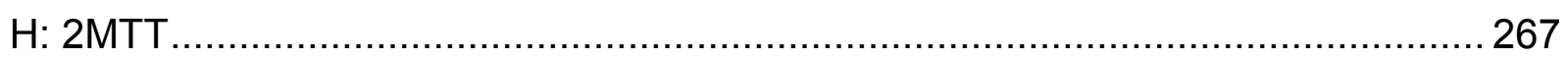

I: Western Australia Construction Camp Regulations ......................................... 279

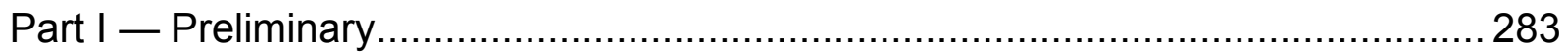

Part II - General regulations for construction camps ...................................... 283

Part III — Caravans used in construction camps ................................................ 292

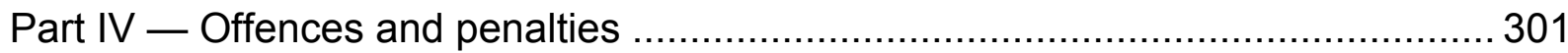

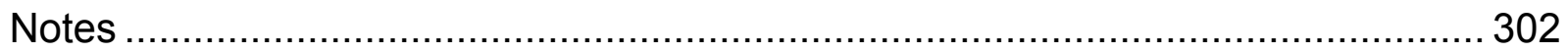




\section{TABLE OF ILLUSTRATIONS}

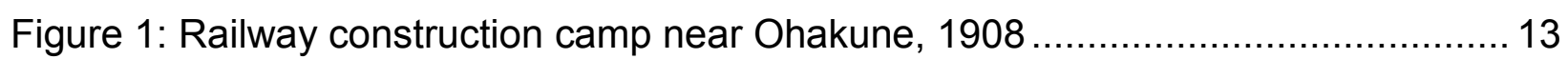

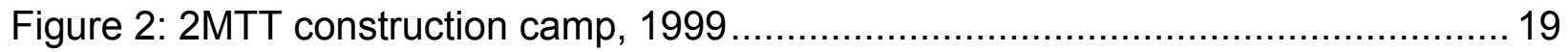

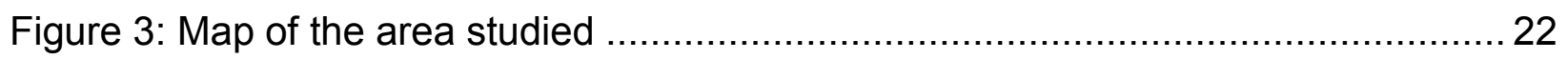

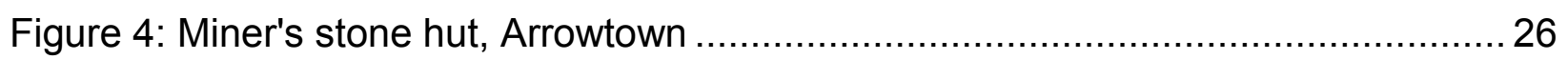

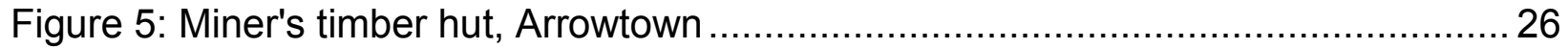

Figure 6: Transportation of a house in Cromwell, 1920s ......................................... 30

Figure 7: Waitaki Hydro electric station and construction camp, August 1934 .............. 35

Figure 8: Singlemens' huts, Waitaki hydro village, December 1928 ........................... 39

Figure 10: Roxburgh Hydro Village town plan ....................................................... 46

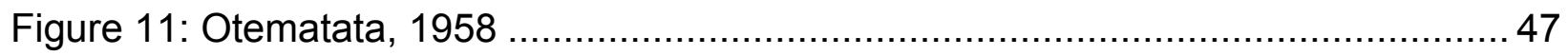

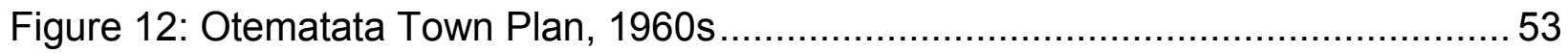

Figure 13: Map of Tailrace Tunnel accommodation locations ................................... 57

Figure 14: The first hut being delivered to West Arm, 1963 .................................... 58

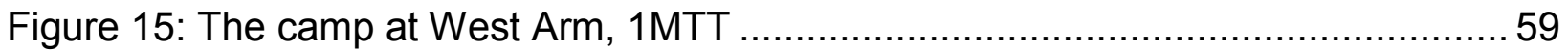

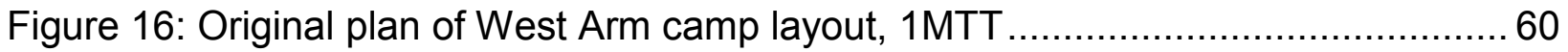

Figure 17: TSMV Wanganella in permanent berth, Deep Cove, 1965......................... 61

Figure 18: Plan of Wanganella at permanent berth, Deep Cove ................................. 63

Figure 19: Steinlager in special cans supplied only to the 1MTT project......................65

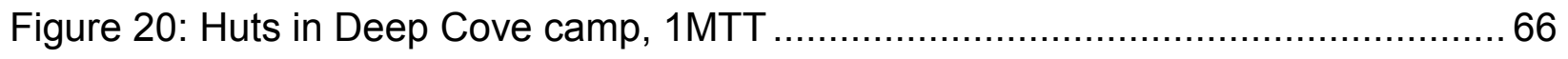

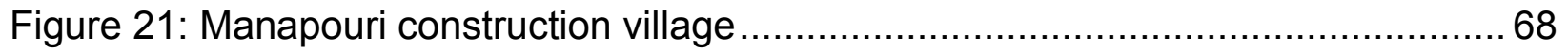

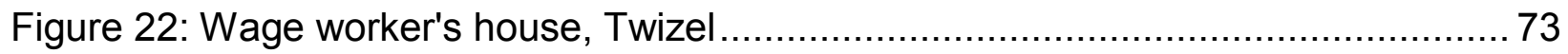

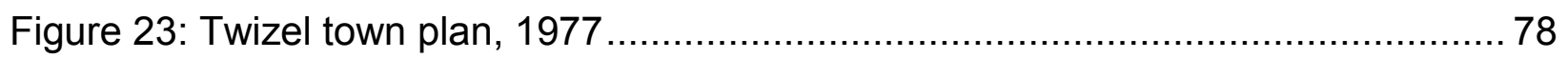

Figure 24: Houses in place at Twizel............................................................... 79

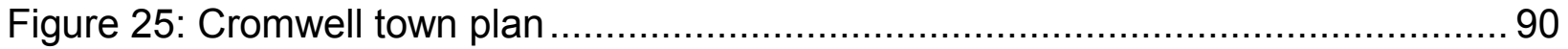

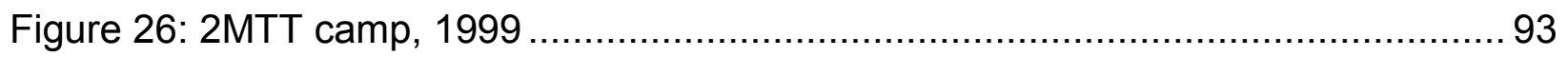

Figure 27: West Arm FDI staff hostel sections being barged out, 2002 .......................96

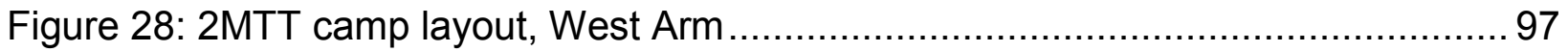

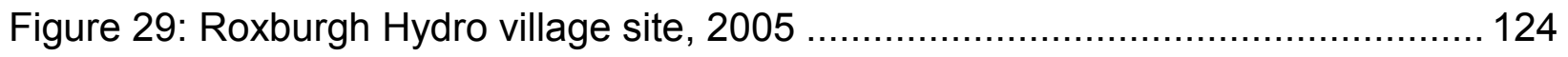

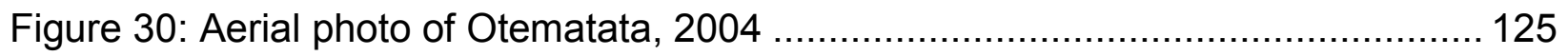


Figure 31: Deep Cove prior to the beginning of construction ................................ 126

Figure 32: West Arm prior to the beginning of 1MTT construction ............................ 129

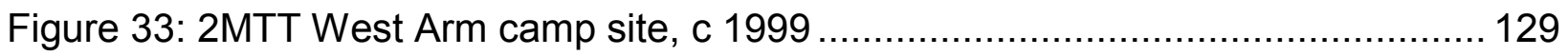

Figure 34: West Arm site under regeneration, 2002 ............................................ 130

Figure 35: West Arm site regenerating, 2004 ..................................................... 130

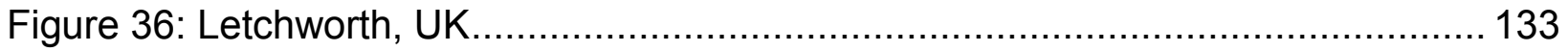

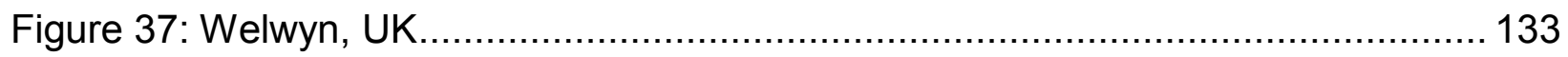

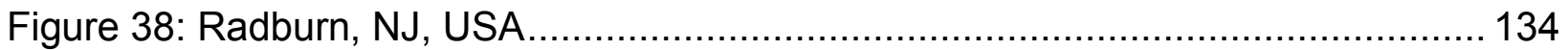

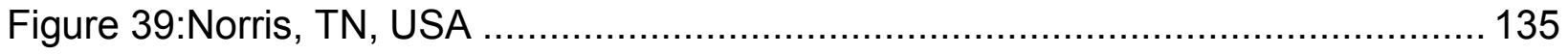

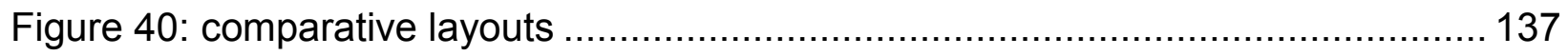

Figure 41: Typical two bedroom state house plan, 1949 ..................................... 143

Figure 42: Typical three bedroom state house plan (without hall), 1949 .................... 143

Figure 43: A singlemens' hut placed next to a house for additional accommodation,

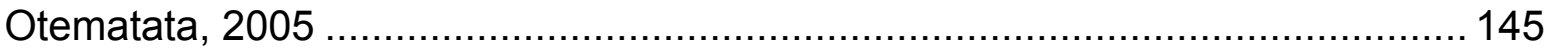

Figure 44: Percentage of original hydro dwellings at Otematata with visible spatial

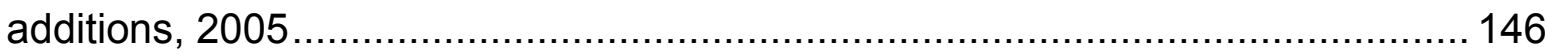

Figure 45: Executive four bedroom house plan, Twizel...................................... 147

Figure 46: Five bedroom staff house plan, Twizel ............................................. 147

Figure 47: Three bedroom staff house plan, Twizel ............................................ 148

Figure 48: Five bedroom wage workers' house plan, Twizel................................. 148

Figure 49: Four bedroom wage workers' house plan, Twizel ................................ 149

Figure 50: Three bedroom wage workers' house plan- type A, Twizel ..................... 149

Figure 51: Three bedroom wage workers' house plan- type B, Twizel ..................... 150

Figure 52: Transportations and transformations of some commonly used buildings ... 156

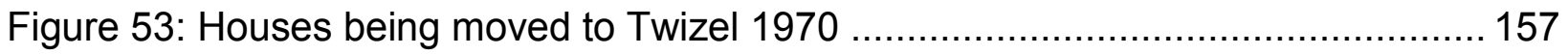

Figure 54: First house being lifted into place at Twizel, April 29, 1969.................... 157

Figure 55: Practical additions as externally visible at Otematata, 2005 ..................... 159

Figure 56: Workers house at Otematata during conversion to Twizel house, 1969 .... 164

Figure 57: Materials changes made to hydro project houses at Otematata as externally

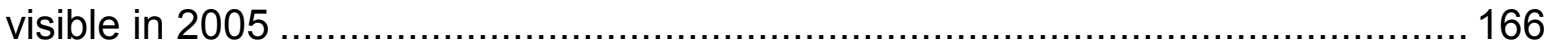

Figure 58: Individualisation alterations and additions at Otematata, 2005 ................. 172 
Figure 59: Hut from West Arm (1MTT) at Manapouri Holiday Park ........................... 178

Figure 60: Hut from Deep Cove (1MTT) at Manapouri Holiday Park.......................... 178

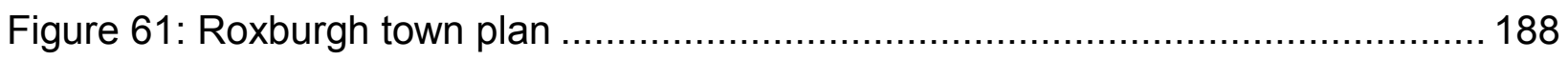

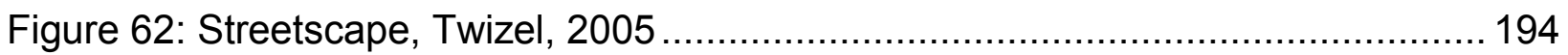

Table 1: Geographical assessment of accommodation sites 116

Table 2: Climatic assessment of accommodation sites 121

Table 3: Environmental protection assessment of accommodation sites 131

Table 4: Layout assessment of accommodation sites 138

Table 5: Chart of hydro house types and sizes compared to state housing standards

152

Table 6: Design changes assessment of houses 153

Table 7: Materials assessment of houses 167

Table 8: Individualisation assessment of houses 175

Table 9: Comparison of singlemens huts 179

Table 10: Comparison of hostels 180

Table 11: Community assessment of hydrotowns 195 


\section{ACRONYMS AND ABBREVIATIONS}

1MTT: First Manapouri Tailrace Tunnel

2MTT: Second Manapouri Tailrace Tunnel

BIW: Built-in wardrobe

DoC: Department of Conservation (NZ)

ECNZ: Electricity Corporation of New Zealand

FDI: Fletcher Dillingham Ilbau

FTL: FTL Happold

HWC: hot water cylinder

MoW: Ministry of Works (NZ)

MoWD: Ministry of Works and Development (NZ)

NZ: New Zealand

NZBC: New Zealand Building Code

NZED: New Zealand Electricity Department

PBRU: Portable Building Research Unit

PWD: Public Works Department (NZ)

RMA: Resource Management Act (1991)

THP: Temporary Housing Programme (UK)

TVA: Tennessee Valley Authority (USA)

UCM: Utah Construction and Mining

UWB: Utah Construction and Mining, Williamson Construction and Burnett Motors consortium

WWI: World War One

WWII: World War Two 


\section{GLOSSARY}

Construction camp: any camp used for a duration of more than 6 months in one location, for the accommodation of a work force of more than 25 persons working on a single infrastructure project

Garden city: an urban planning model which results in planned, self-contained towns and cities which are surrounded (and often incorporated within) green belts.

Hydro town: a town occupied by a workforce (and their accompanying families) employed on a single hydro electric project and the services necessary to support them Permanent: for the purposes of this thesis "permanent" is taken to mean an intended usage of over 15 years for a single purpose in a single location

Public works: infrastructure projects carried out by the government for public use Singlemens' accommodation: accommodation provided for workers with no accompanying family

Single purpose town: for the purposes of this thesis, "single purpose town" is used to mean the same as a hydro town, except that employment may be on any single infrastructure project

Temporary: for the purposes of this thesis "temporary" has been taken to mean 15 years or less use for a single purpose in a single location

Transportable: able to be moved in single or a small number of units from one location to another in a simple manner 


\section{INTRODUCTION}

"One can scarcely blame the residents for having wanted to leave the settlement at every opportunity, for the extremes of the climate and the rather dreary environs did not encourage any firm attachment to the place"1 - a resident describes the living conditions at Roxburgh Hydro

"It really was nice, the lounge and each of the four bedrooms papered and painted; the kitchen, laundry and bathroom area decorated in warm tones. We applauded the prospect of a brand new home so superior to our little house in Otematata" - a resident describes the living conditions at Twizel

The history of the European colonisation of New Zealand (NZ) shows construction camps in existence from the very early days. Vast areas of undeveloped terrain between settlements, the gold rush and a desire for farmable plots led to road and rail construction across the country. Construction camps were in evidence throughout NZ and photos and published accounts of conditions in these camps are available in biographies and autobiographies of the time.

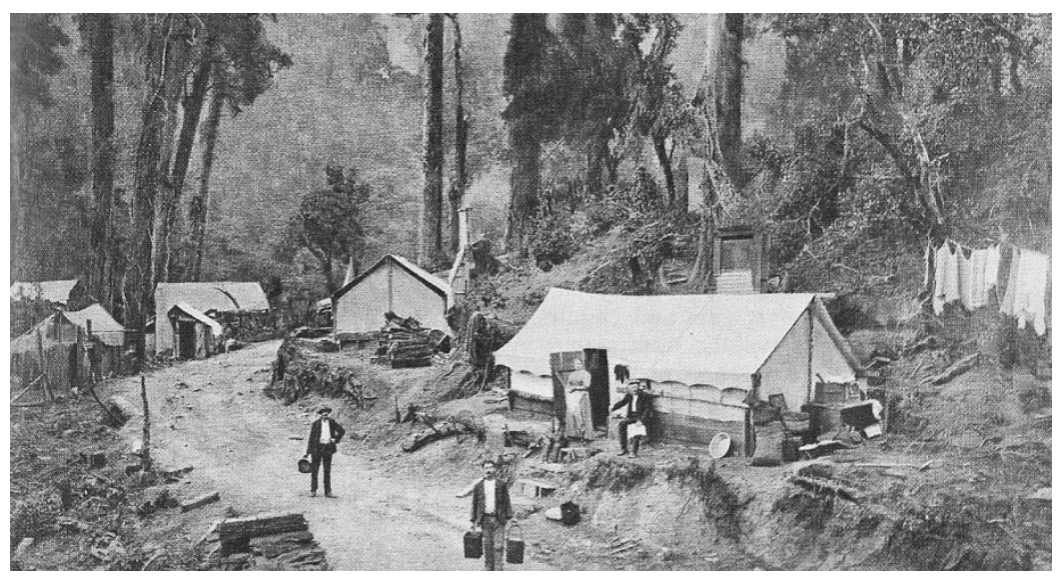

Figure 1: Railway construction camp near Ohakune, 1908

While these camps were relatively small in scale, they set a precedent for what was to follow.

\footnotetext{
${ }^{1}$ Campbell, p 55

${ }^{2}$ Sheridan, p 116
} 
By the $20^{\text {th }}$ century there were many hydro projects of varying scales being carried out throughout NZ, but it was not until the end of WWII that both the technology and the manpower were available to tackle the large hydro projects which form the mainstay of NZ's current electricity production. The remote nature of the sites necessitated the supply of temporary construction camps and the length of the projects and national housing shortage promoted the introduction of family housing in some, while the national importance of other sites prompted a concern for environmental protection in the remainder.

The inclusion of family housing required a new way of looking at construction camp design and planning and the camps evolved into temporary single purpose towns. As each new town was constructed, design changes were made to all types of accommodation and throughout the lifespan of each town the family dwellings (and the sections that they were located on) were individualised by their occupants.

While the mass-produced accommodation was comfortable when first built, it was the evolution of the typology through several townships, combined with occupant modifications, which transformed the family accommodations into homes. This resulted in towns which were retained after the project was completed and became permanent townships, eventually culminating in the construction of family accommodation at Cromwell as permanent housing to be sold off after completion of the project.

There was also a strain of camp design evolution occurring during this period centred around site protection which produced singlemens' camps which were removed and regeneration encouraged so that no remnants were visible once the project and the regeneration term were completed.

This evolutionary dichotomy has provided excellent solutions for the contemporary concerns of environmental protection and family accommodations. However, reading through the history of the hydro camps suggests that the evolution has been self-regulating for the last 90 years.

Rosslyn Noonan has written a brief history of the camps (By Design: A Brief History of the Public Works Department Ministry of Works 1870-1970) and notes that "by 1920 conditions and pay for public works employees put them amongst the worst 
off in the country" ${ }^{3}$ and that this was severely affecting staff retention and the quality of applicants. A combination of ministerial and union initiatives led to the 1921 Public Works and Construction Workers Agreement ${ }^{4}$ and "this was the beginning of the department's recognition that it was in its own interests to compensate its workmen as far as possible for the deprivations of working in isolated and unsettled areas"5. Noonan goes on to describe how improving working and living conditions helped towards building a permanent workforce for the Ministry of Works and Development (MoWD - the NZ Ministry responsible for public works) but was ultimately outweighed by the worsening economy ${ }^{6}$, which encouraged supervisors to seek written agreements with workers accepting conditions which violated the 1921 Agreement.

By the 1940s conditions in the camps were improving again and the temporary MoWD camp at Mangakino showed the beginnings of "more careful planning and design of construction towns instead of allowing the haphazard development of huts that had prevailed in the past" planning of Roxburgh Hydro was begun, using lessons learnt at Mangakino (amongst other camps). From here Noonan gives a lot less information in regards to the design guidelines and intentions of the towns. Campbell, in his history of Roxburgh Hydro, Hydrotown: The Social History of an Industrial Boom Settlement, describes the accommodations in place and some of the history of the town planning ${ }^{8}$, but does not address the design process. This lack of information about the design intentions and any guidelines which the MoWD was following are missing from all of the documentation visited in this research, including the MoWD's own files in the National Archives.

W. Frank Ponder briefly mentions his responsibility "for setting up both the 'temporary construction village' and the permanent hydro village" at Roxburgh ${ }^{9}$ early in his architectural career, suggesting that while the most senior architects in the

\footnotetext{
${ }^{3}$ Noonan, p101

${ }^{4}$ See Appendix A

${ }^{5}$ Noonan, $p 107$

${ }^{6}$ ibid, p 117-8

${ }^{7}$ Ibid, p190

${ }^{8}$ Campbell, p5

${ }^{9}$ Ponder, p24
} 
MoWD were designing permanent architecture for the powerhouses at the dams ${ }^{10}$, they left the majority of design and documentation of the accommodations to the more junior staff. Ponder also mentions his having to visit the site to discuss living conditions with workers who were threatening to strike ${ }^{11}$.

Combining these factors with Marion Sheridan's description of union efforts to secure upgraded accommodations at Otematata ${ }^{12}$ and then again at Twizel ${ }^{13}$ and Andrew Leach's observation that "the Hydroelectric Design Office enjoyed relative freedom all the way through to the design of Manapouri (1968-73), when rigid legislative environmental controls [sic] introduced; before this, engineers and architects were under looser guidelines", ${ }^{14}$ it does seem that the MoWD was following design guidelines for the accommodations that were both flexible and selfregulatory (with some input from residents and unions) and, most likely because the MoWD was a government department, they were immune from the permanent housing standards.

When the design for the housing became permanent at Cromwell, the State Housing Department stepped in and took over the design responsibility, applying both the NZ Building Standards and its own standards.

The only large scale hydro camp since the abolition of the MoWD has been the Second Manapouri Tailrace Tunnel (2MTT) which was designed and developed by private enterprise and was required to meet the standards set by the NZ Building Code (NZBC - a performance-based code which forms the first schedule to the Building Regulations 1992) and additional environmental protection guidelines as well as the Resource Management Act 1991 (RMA).

If Meridian Energy proceeds with constructing a new hydro scheme on the Waitaki River, accommodation for several hundred workers will be required (at

\footnotetext{
${ }^{10}$ For a full description of the architectural input into the dam powerhouses see Leach, Power Architecture

${ }^{11}$ Ponder, pp23-4

${ }^{12}$ Sheridan, $\mathrm{p} 10$

13 Ibid, pp91-3

${ }^{1414}$ Leach, Power Architecture, p130
} 
August 2010 the press is reporting that $3-400$ workers will be employed for the construction $)^{15}$ and there are no legislative guidelines to assist in the design.

While the NZBC is suitable for permanent dwellings, temporary accommodation (especially transportable hostels) should have separate regulations to meet the needs of an entirely different function (see Appendix I for the Western Australian Construction Camp Regulations, which addresses issues such as space between beds, air space in sleeping quarters, dining room tables, caravans, etc).

The scope of a masters thesis is too narrow to establish new guidelines, so this research examines worker accommodations at large infrastructure projects in NZ during the $20^{\text {th }}$ century to find the lessons that we can learn which may be used to inform future worker accommodations in order to prepare the way for future research, answering the question:

What can we learn from worker housing developed around large infrastructure projects in New Zealand in the 20th century that may be used to inform development of worker accommodation in the new paradigm (that is, without the Ministry of Works and Development)?

The south of the South Island has been chosen as the subject of this research because the sparsely populated nature of the land has encouraged the implementation of multiple large resource-based construction projects (mainly hydroelectric dams), all of which have required the provision of workers' accommodation (which may not have been necessary in areas where workers could commute from large towns or cities). These camps have flowed consistently from project to project in the south, the years $1991-96$ are the only ones in the second half of the $20^{\text {th }}$ century in which accommodation in large scale hydro construction camps was not provided somewhere in the region, providing a continuous timeline for study. These camps had an occupying management and workforce which was culturally diverse and shared a history of construction camp habitation.

Three events caused a major deviation in the design evolution of the case studies:

\footnotetext{
${ }^{15}$ Several numbers have been reported in The Press and The Otago Daily Times in the first week of August 2010 as reports are published of Meridian Energy receiving water use consent for the North bank Tunnel proposal
} 
- the New Zealand Electricity Department (NZED - the NZ government department responsible for electricity) was corporatised in $1987^{16}$

- the MoWD was abolished in 1988 (and the government subsequently announced its intention to let out future construction work to the private sector $)^{17}$

- the Resource Management Act (RMA) was introduced in 1991

Combined, these events led to a rapid transition from government subsidised and run single purpose towns and construction camps which had evolved through many years of consecutive hydro projects, to an unknown future in the hands of private enterprise with few guidelines.

In 2001 Meridian Energy publicly announced plans for a new hydro-electric scheme in the Waitaki Valley, commonly referred to as Project Aqua.

There was much publicity in the local media ${ }^{18}$ about the employment creation, environmental impacts and local community concerns. However there was little discussion or planning in evidence in regards to the workforce accommodations for Project Aqua, despite the huge impact that the workforce accommodations at Waitaki and Otematata had made on the district previously. Meridian did indicate that they were planning on housing most of the workforce at Campbell Park, with some boarding in Kurow.

The abolition of the MoWD in 1988 had created the need for new types of construction camps due to privatisation of the large infrastructure construction projects, as was seen at 2MTT. Privatisation of infrastructure construction projects took government control away from single purpose towns and thus took away subsidisation of facilities. This combined with the introduction of the RMA to create more likelihood of singlemens camps being provided than of single purpose towns being created (ie: accommodation provided for workers only, with no provisions made for accompanying families).

\footnotetext{
${ }^{16}$ Taylor et al, "A Case Study of Twizel", p13

${ }^{17}$ Ibid, p8

${ }^{18}$ Local media includes Otago Daily Times, Southland Times, The Press, The Oamaru Mail, The Timaru Herald
} 


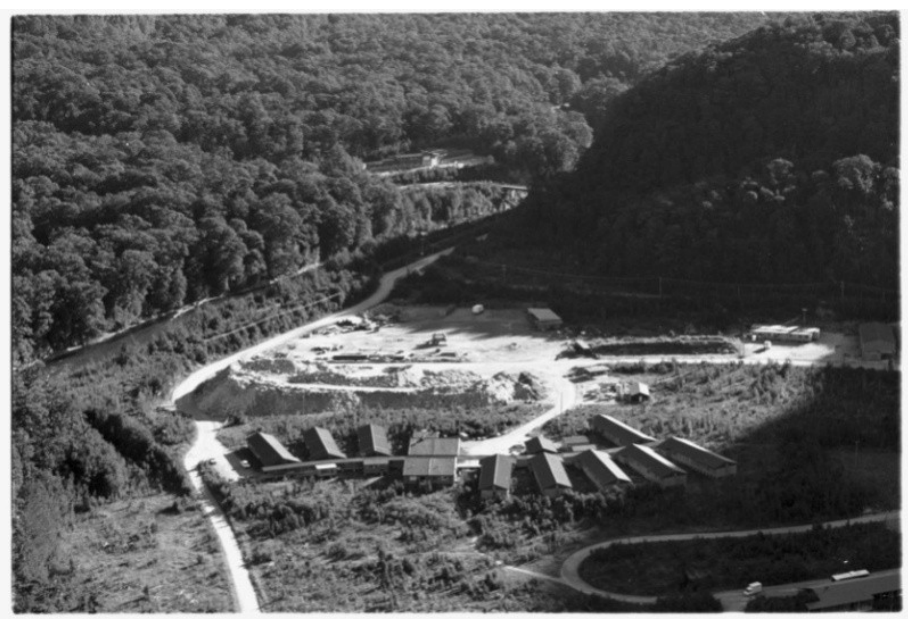

Figure 2: 2MTT construction camp, 1999

The omission of construction workers' accommodation provisions in the initial Resource Consent applications ${ }^{19}$ raises questions as to how the housing for construction workers would differ from previous projects.

There are three sections to this research. The first looks at the history of the construction camps and single purpose towns in the region. During the research it became apparent that there has been very little written about these towns and camps and some of them have been completely removed. Therefore, it was necessary to write a historical record of what existed in order to be able to assess it. Some contrast is provided with contemporaneous international examples in order to show the progression of design in the wider context.

The historical narrative describes the accommodation. In order to do this, the facts have been gathered from published and unpublished, primary and secondary sources and every attempt has been made to verify the information from multiple sources (although this has not always been possible). These case studies have been further supported by the photographic evidence in the appendices.

The second section elucidates the research methodology used to write this paper. The methodology relies heavily on text-based investigations. Although little was written about the design of the construction camps and single purpose towns while they were in existence, many publications included small references to them

\footnotetext{
${ }^{19}$ The majority of Resource Consent applications for Project Aqua were submitted together on 14 May 2003
} 
and, by combining these with the papers in the National Archives and the three publications which included some deeper discussion of the sociological conditions within the towns, enough information has been gathered to make a critical assessment of the accommodation types and their evolution through a combination of multiple case study and historical-interpretive methodologies ${ }^{20}$. This section explains how qualitative artifactual evidence led to the use of these methodologies and the ways in which they have been implemented to inform the framework of this research.

The third section is a critical assessment of evolutionary changes to the sites and to the accommodation types provided. The assessment begins with analysis of the site selections, camp layouts and environmental protection and reparation measures undertaken. The concerns for the impact of site selection have evolved from transportation concerns to occupant comfort to environmental protection through the history of the camps. Analysis of the sites has been made on the basis of the success of the camps in meeting these concerns. The weighting of various concerns at each camp location has varied and records do not show which considerations were of most importance to the camp planners, so each camp's success has been assessed on the same criteria in order to illustrate the changing concerns.

There has been little record of the design stages of the camps (and even less which can be verified by triangulation of sources) and, therefore, no direct record of the desired impact of the accommodation designs at the design stage. Some records have been deposited in the National Archives, but these are often incomplete narratives. Analysis is made based on the records available and on direct observation where the buildings are still standing. By comparing the built examples, a measure of the success of the designs has been determined.

Living in the region and frequently visiting the remaining towns (and relocated singlemens accommodation) has been of some use in understanding the continuation of the evolution of the buildings.

In assessing the impact of designs, consideration is also given to the national concerns of the day and the wider context (for example, some international

\footnotetext{
${ }^{20}$ Using Groat and Wang as a reference
} 
examples) is taken into account as an element of the design suitability. It is acknowledged that construction camp design is not self-contained or selftransforming, but is a sector of housing as a whole and thus these camps address concerns which are not wholly those of the hydro project. 


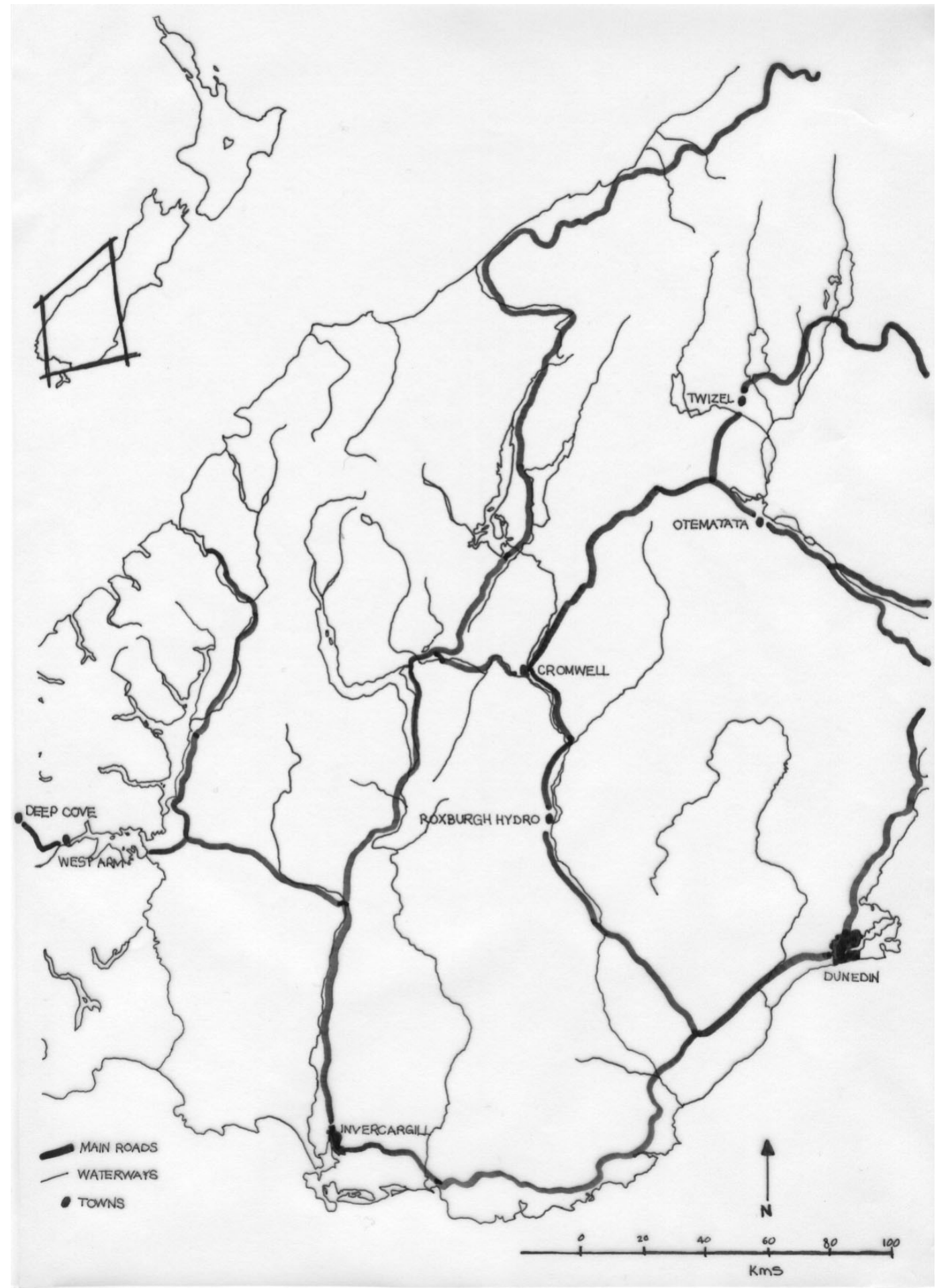

Figure 3: Map of the area studied 


\section{CHAPTER ONE: CASE STUDIES}




\section{HISTORY}

"A house will no longer be this solidly-built thing which sets out to defy time and decay, and which is an expensive luxury by which wealth can be shown; it will be a tool as the motor car is becoming a tool" 21

Le Corbusier, 1923

The Maori have lived in the south of NZ for centuries, yet much of the area covered in this research was not settled, instead providing travelling routes between the east and west coasts and hunting grounds in the warmer months.

The first large wave of non-Maori settlers into the region studied in this research (some European whalers and sealers had previously lived in coastal regions, but were not resident in any great numbers and rarely did they venture very far inland) were the European gold miners of the 1860s, followed soon afterwards by the Chinese gold miners. These men lived in very primitive conditions, often building their own huts predominantly out of stones (see fig 4), though in some places the miners were able to find timber that had not been put to use in the gold dredges or mines. Often whatever timber could be found was reserved for roof framing, but occasionally there was enough to line the walls, although this was commonly used for storage huts without internal fireplaces. The Chinese miners would use rock overhangs, where possible, to provide walls and sometimes a partial roof, for their huts (see fig 5), but this practice was not common amongst the European miners.

The support services for the gold miners included traders, bankers, hoteliers and publicans and soon created the service townships of Roxburgh, Clyde, Cromwell, Arrowtown, Alexandra and Queenstown, as well as hotels scattered throughout the countryside. Most of the early hotels and shops were constructed of stone and mud, usually with corrugated metal roofs. Supplies and materials for the shops etc, were brought in on horseback along narrow pathways which were often high up on the sides of gorges. This made corrugated metal and other building supplies particularly hard to come by and expensive.

Once the gold rush started to die down, many European miners chose to settle in the area, often planting orchards or small scale farming, while the vast majority of

${ }^{21}$ Le Corbusier, p219 
the Chinese miners left the area to either return home to their families or to find work elsewhere. The Chinese had paid a large bond to enter the country and most were unwilling to lose this bond by settling in NZ, particularly as the Europeans were often prejudiced against the Chinese. Also, very few were able to afford the astronomical "bond" payment required to bring a Chinese woman into New Zealand and thus were unable to have their loved ones join them and to start a family.

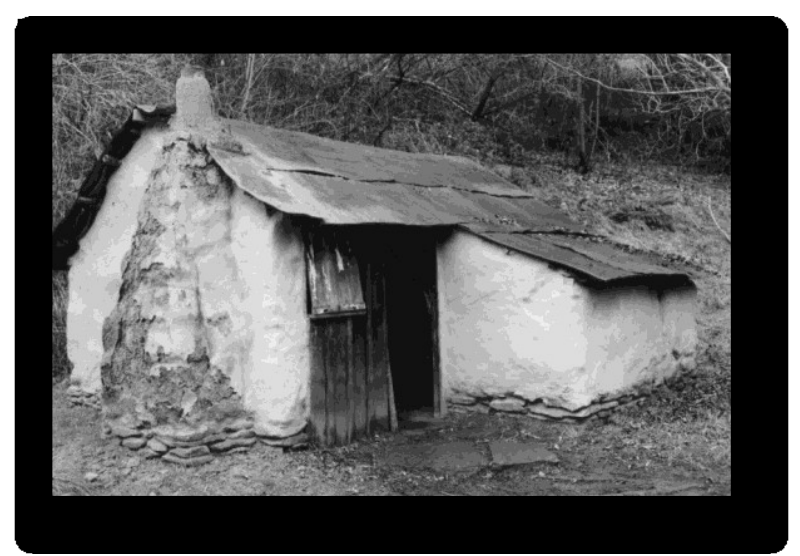

Figure 4: Miner's stone hut, Arrowtown

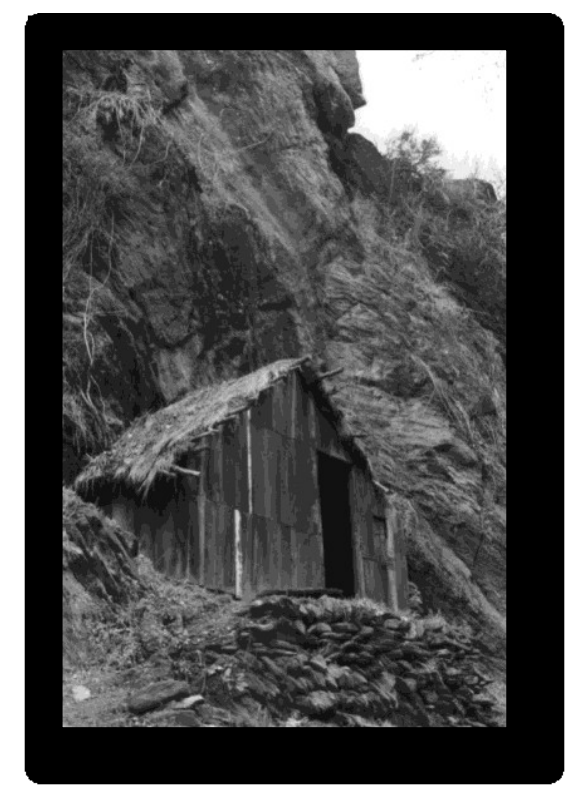

Figure 5: Miner's timber hut, Arrowtown

Around the same time as the mining boom the large run holders of the region began to stake their claims and high country farming commenced. This required more workers in the form of stockmen and the run holders became the largest employers in the area after the gold rush. The stockmen usually lived alone or in 
very small groups of two or three, often moving between the stone and timber huts scattered throughout the stations. Ruins and remnants of the travellers' hotels and stockmens' and miners' huts can be seen throughout the region today.

Although NZ had been one of the largest markets for transportable buildings in the mid $19^{\text {th }}$ Century (for example, immigrants to Australia and NZ purchased large numbers of Manning's portable cottages ${ }^{22}$ ), the requirement for further transportation from harbours to Central Otago made these buildings less common in the area studied, where in situ construction was the vastly more popular option.

Prior to the Immigration and Public Works Act of 1870, each province of NZ was responsible for financing and carrying out their own infrastructure projects. This rapidly led to uneven standards of roading, differing railway gauges and other similar discrepancies between provinces.

The Immigration and Public Works Act made public works a national concern and went even further, forbidding provinces from raising capital for public works (effective until the 1876 Abolition of the Provinces Act).

However, labour shortages stymied the effectiveness of the new Public Works Department (PWD) to the extent that it was almost abolished. This problem was partially solved by introducing unemployment relief programmes in 1878. These continued until WWII and entailed reduced wages and irregular work for the otherwise unemployed. This did not solve the problem of a lack of skilled workers however and immigration was widely seen as the solution to this problem.

Co-operative workers were used to fill many of the unskilled labour positions on the early PWD projects, but acceptance of this was declining by the turn of the century as conditions in the construction camps created increasing discontent. In 1891, as part of a move to improve conditions, rules were set out by the PWD regarding accommodation for co-operative workers on construction projects - each worker required to live away from home was issued one $6 \mathrm{ft} \times 8 \mathrm{ft}(1.8 \mathrm{~m} \times 2.4 \mathrm{~m})$ tent, which was increased to two tents if their family wished to live with them.

Although suggestions were made within the PWD in 1898 to replace tents with huts, this was not progressed and conditions were still unimproved in 1908 when the

${ }^{22}$ Bergdoll and Christensen, p40 
PWD found it necessary to remind the engineers in charge of construction projects of the rules relating to the issuing of tents to the workers (still unchanged since 1891).

At this time, living conditions in NZ cities for low-income families had deteriorated and the existence of inner city slums prompted the government to consider minimum standards of living. A national state housing programme was tentatively begun in 1905 with the Workers Dwelling Bill which introduced state-owned housing on the outskirts of cities. However, rent was higher than anticipated (due to poorly estimated construction costs) and this combined with lack of transport in some areas and the cost of transport in other areas to make the new housing unappealing to the urban poor. The government attempted to counter this with the 1906 Government Advances to Workers Act and the 1910 Workers Dwellings Act.

However, while conditions were slowly improving in the cities, living conditions in PWD camps were not. In 1911 an inquiry into living conditions in the PWD construction camps was called for by the PWD itself, as a result of widespread labour disputes and union reports (for example, living conditions were reported as one of the main causes of labour disputes on the Otira tunnel project in 1912).

The PWD had been given increased functions in 1903, when the Water Power Act gave it responsibility for hydro-electric development and this increased the PWD workload significantly as demand for power outstripped supply right from the start. In order to meet this demand a report was commissioned in 1918 and this set out a system of interconnected power stations throughout NZ (which forms the basis of the network today). The PWD did not want further labour disputes disrupting projects, especially in the face of such an increase in projects.

The combination of World War One (WWI) and the flu epidemic had resulted in a shortage of workers for a few years, but the end of WWI saw the return of many men to the country and there was a sudden abundance of unskilled workers available for the large scale PWD civil construction projects. Much of this workforce was spread along roads and railway lines, making it impossible to effectively share communal facilities and, therefore, exacerbating the existing PWD accommodation shortage with poor conditions. The standard of living on these projects became so bad that it 
again affected staff retention rates and in 1920 negotiations began between the unions and the PWD to address the standard of living (as well as other issues). This culminated in the 1921 Public Works and Construction Workers Agreement ${ }^{23}$. This included the following requirements:

"HUT ACCOMMODATION

Single men to be provided with $10 \mathrm{ft} x 8 \mathrm{ft}$ hut, suitable bunk and fireplace; married men without family to have hut with room $24 \mathrm{ft} x 10 \mathrm{ft}$, plus a room $10 \mathrm{ft} x 9 \mathrm{ft}$ for use as kitchen. Married men with a family up to four children to have two rooms $24 \mathrm{ft} x$ 10ft; for every additional two children, one 10ft $x$ 8ft hut to be added. Bathing facilities, wash-house and cooking range, also fireplace in living room to be provided. Mattress to be provided, the Union to be responsible for prevention of abuse of mattresses.".....

"TENTS MAY BE USED TEMPORARILY

The use of tents will be restricted as much as possible on railway construction works, and where used shall be framed, and floored, and supplied with a limited amount of timber sidewalls, and provided with fireplace and chimney attached."

The Agreement echoed the concerns of the Minister of Public Works, Joseph Gordon Coates, who expressed his belief that the standard of living was crucial to attracting and retaining good staff ${ }^{24}$.

The Agreement raised living conditions where it was implemented, but it was not always enforced and many aspects of it relied heavily on its interpretation by the engineer responsible for each project.

While the early 1920s saw the PWD working towards training and retaining a stable skilled and unskilled workforce, the late 1920s saw rising unemployment and another push to provide work for the unemployed, which led to neglect of staff retention methods and the reduction of permanent positions in favour of temporary and contract employment.

${ }^{23}$ See Appendix A
${ }^{24}$ Noonan, p107 


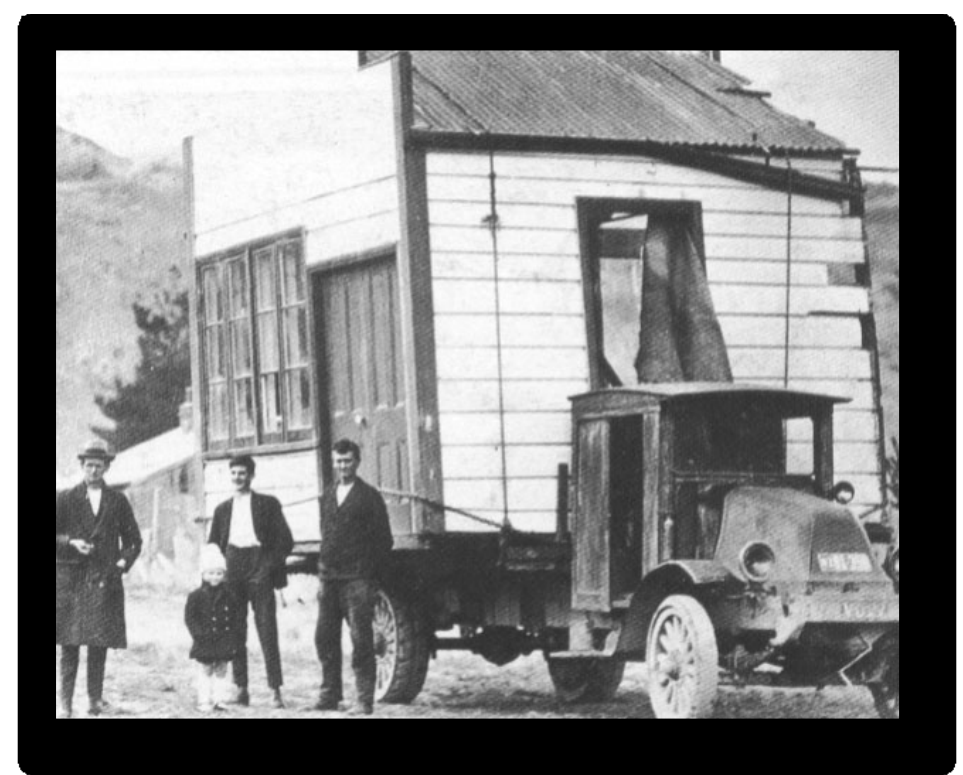

Figure 6: Transportation of a house in Cromwell, 1920s

Construction contractors during this period often lacked sufficient experience on large scale civil projects and this led to economic difficulties and further exacerbated staff retention problems. (For example, the head contracts on the Arapuni Dam failed to foresee common excavation and geological problems which in turn meant huge cost over-runs and further angered staff already living in poor conditions with unconfirmed rumours that the overseers had made employees sign a waiver to the rights under the 1921 Agreement as a cost-saving measure.)

The problems at Aranui combined with the 1929 Wall Street crash (and the subsequent Great Depression) led to a $75 \%$ PWD budget cut, announced 7 March 1932. Waitaki was the only power generation project to survive and continue construction.

In 1931 the Unemployment Board had begun organising unemployment relief camps for single men. These were organised by the PWD and subsidised by the Unemployment Board and were extended to married men in 1932. However, the living conditions were terrible and the PWD was powerless to improve them under the new budget.

When the Waitaki dam was built (1928-35), the workers had a strict social stratification, separation between the married and singlemens' quarters, no gardens and outside toilets. The houses were cold, with a coal range as the only "appliance" 
in the house and there was no insulation. The accommodation was infested with rats and mice, but the men did not grumble as they were grateful for the huts and houses, which included a small stove, as in previous hydro towns they had been provided with tents against the bitterly cold winters ${ }^{25}$.

The PWD budget began to increase again in the mid-1930s, but it was too late to affect the unemployment relief camps which were abolished along with all PWD relief work in 1936. New negotiations with the NZ Workers Union led to all jobs becoming standard, with increased wages and an agreement on working conditions for those working on construction projects. These agreements included a revised standard of housing (although not vastly different to that provided in the 1921 Agreement), provision for recreation halls, libraries, cookhouses and canteens, as well as cheap fuel provision where it was not otherwise available.

Also in 1936, the Department of Housing Construction was created for the construction of state houses, with an understanding that the PWD would prepare all sites for state housing. However, the Department of Housing was soon fully incorporated into the PWD.

In 1939 both men and machinery were again diverted to the war effort, leaving another shortage of workers and materials. However, the deployment of US forces to the Pacific required large camps to be built near Paekakariki in the North Island and this gave the PWD a chance to show off its abilities. Buildings for the camps were prefabricated in the South Island, then shipped to Paekakariki and assembled. One camp was designed and constructed (including site prep and services) for 20,000 men in six weeks.

In 1943 the MoWD was established to consider all government construction projects and to decide on finance priorities, particularly whether the PWD should build each project or if it should be put to tender or built under a negotiated contract with a private construction firm. These considerations covered state housing as well as large scale civil projects and led to a reorganisation of the PWD - the Housing Construction Department was fully absorbed into the PWD, while the hydro-electric

${ }^{25}$ Natusch, p11 
branch was separated. The PWD was divided into four divisions - engineering, architectural, housing and administrative.

The 1940s finally saw the start of organised planning and design of construction towns in NZ, as opposed to the previously unregulated growth of camps as tents and huts were added wherever as needed and wherever was easiest to put them. This function fell to the Housing Division of the PWD and examples from overseas were investigated to provide suggestions for the way forward.

Towards the end of WWII the Allies had recognized that there was a massive housing shortage for the returning soldiers. In Britain the response to this was the 1944 Ministry of Works Emergency Factory-made House Programme, which led to the 1944 Housing (Temporary Accommodation) Act. A quarter of houses in Britain were damaged, soldiers were returning from the War and it was anticipated that the birth rate would greatly increase as soldiers started families, all leading to an anticipated requirement for up to 4 million new homes in the decade after the War.

While the need for permanent housing was acknowledged, it was also brought to the government's attention that there was a massive shortage of skilled labour which could be at least partly met by the increased manufacturing sector if prefabrication was utilised.

The Temporary Housing Programme (THP) was seen as a short term solution to the housing problem. The British government set a range of criteria that all prefabs had to meet $^{26}$ :

- All prefabs designed in Britain had to last for 15 years

- They had to make the best use of the materials that were in abundant supply

- They had to make minimal use of timber

- They had to avoid the use of bricks

- The government-approved 'heart unit' of back-to-back kitchen and bathroom plumbing had to be used

- As many parts as practically possible were to be factory-made

- They had to be easily transportable by road (ie: a maximum width of 7.5 feet $(2.3 \mathrm{~m}))$

${ }^{26}$ Stevenson, p59 
- All prefabs had to be able to be easily and quickly constructed on site with minimal use of traditional skills

In order to meet these criteria, various by-laws within Britain that restricted innovation in construction techniques and materials had to be revised.

Nearly 160,000 temporary houses were constructed under the THP, of 13 different government-approved varieties. Many of these were not designed to be transported any further than their first site, but some designers were forward-thinking enough to realize that their designs would easily exceed the required lifespan and designed transportable systems so that the housing could be utilised after replacement by permanent house types.

While the resettlement of vast numbers of people originally led to a sense of isolation and loss of community, the need to share rationing recipes, the shared experiences of returned soldiers, the vast number of children on the estates (very few families with less than two children were allocated a prefab) and the lack of private transport, among other things, rapidly led to a great sense of community which many who lived in the estates felt has not been exceeded in any housing experiment in Britain since. There was also a very low crime rate in these estates, despite the fact that often all the front door keys in an estate were identical, perhaps encouraged by the provision of appliances and amenities that were identical in all prefabs and seen as luxurious by much of Britain ${ }^{27}$.

However, the prefabs were not a great success for the government, as all types were more expensive than anticipated ${ }^{28}$, demonstrating that the preconceived notion of savings from factory production of housing was not a reality. This led to many less prefab estates than were required. The only real bonus for the government was the continued employment of the population in industries which had swollen during the war years.

By 1975 , over $90 \%$ of the THP prefabs had been demolished, not because of structural failure, but because the Councils could build two houses on each prefab lot owing to the size of the gardens allocated to each prefab.

${ }^{27}$ Ibid, p173
${ }^{28}$ ibid, p223 
Meanwhile, a craze for trailer homes had swept through America, starting in $1937^{29}$. While they had initially been adopted as recreational vehicles, in a similar format to caravans, the Depression of the 1930s soon saw families moving into them as fulltime accommodation.

Another solution for housing the large number of returning soldiers who wished to start families was that of the Tennessee Valley Authority in North America.

Commonly referred to as TVAs, photographs of these buildings being delivered on the backs of trucks in modular form and three or four modules being bolted together on site to create an entire house were reproduced throughout the English and American media. The TVAs utilised the heart unit module with all services supplied through a single module and other modules simply being volumetric shells. The images of these widely promoted the concept of factory prefabrication which continued for the next two decades and photos of the designs were widely disseminated through the PWD.

${ }^{29}$ Wallis, p4 


\section{Waitaki 1928-35}

"The site was isolated, windswept and extremely cold in winter. Waitaki Hydro was a public works camp unique to its time, partly because of the size of the project and the climate, both of which necessitated it being more of a town, but also because it largely kept to the pattern of improved living conditions that had emerged in the 1920s - most public works camps reverted back to tents during the Depression ${ }^{30 "}$

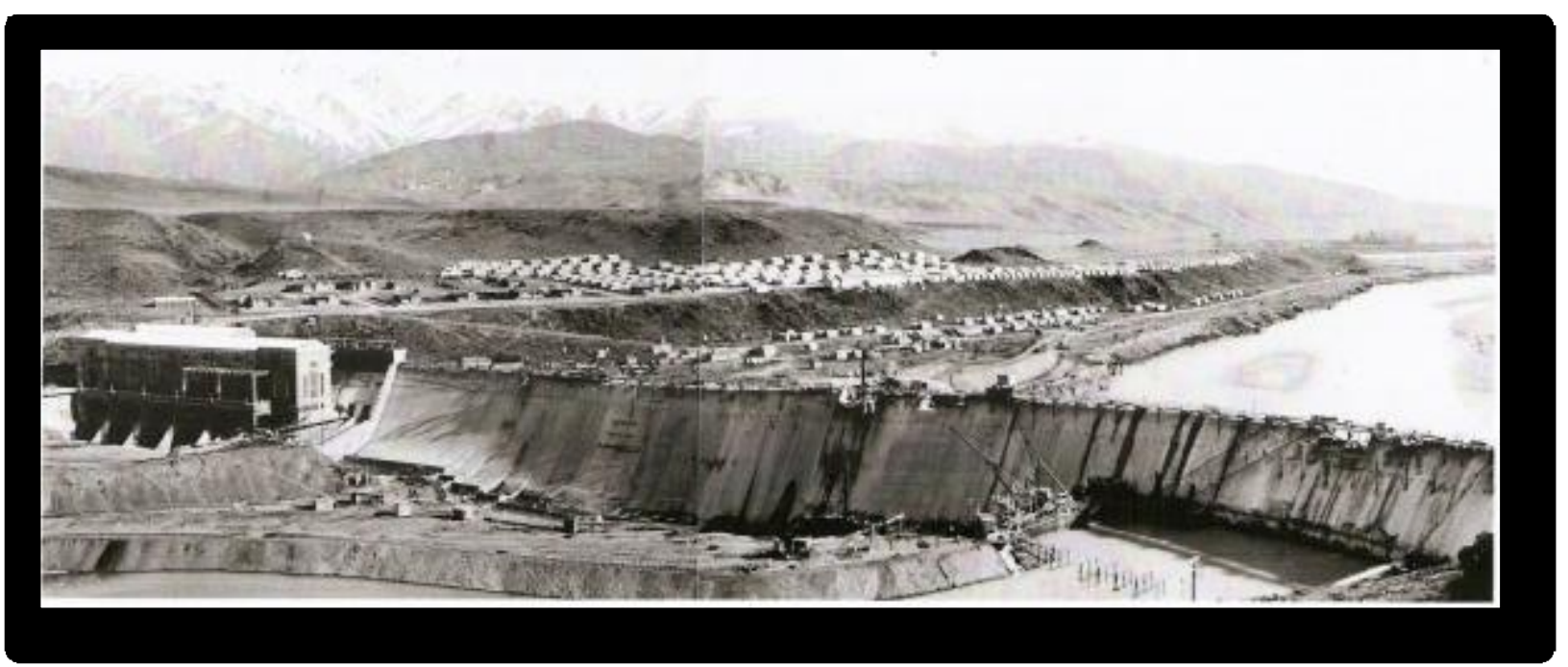

Figure 7: Waitaki Hydro electric station and construction camp, August 1934

The Waitaki hydro camp was initiated in 1928 as a "make work" construction programme run by the Public Works Department to provide employment in New Zealand during the Depression.

While this camp is commonly seen as the birthplace of social security and welfare in New Zealand ${ }^{31}$, the workers were often far from financially secure, with the workforce halved and wages and salaries reduced in 1932 as the beginning of the Depression brought electricity use to an all time low (and thus reduced the need for the dam). The year 1933 brought a growth in electricity use and a subsequent growth in the workforce and an eventual increase in wages and salaries.

\footnotetext{
${ }^{30}$ Martin, J, p108

${ }^{31}$ Natusch, p46
} 
Initially a temporary camp was built to house 1000 workers and their families ${ }^{32}$. Although previous PWD camps had consisted of canvas tents, it was decided that the climate at Waitaki, combined with the expected duration of the project, required the installation of timber huts and houses with malthoid roofs, as specified in the 1921 Public Works and Construction Workers Agreement (Appendix A). The timber huts and houses were more substantial than the tents but still lacked insulation. By closely packing the houses and huts some of the cold and wind was mitigated despite the building materials.

The camp was built on two river terraces and eventually encompassed four distinctly separate living areas: the camp on the upper river terrace was the main camp and had full facilities (as described below). The camp on the lower terrace was known as 'Siberia' because it was exposed to the winds (and the accommodation was less substantial) and was inhabited mainly by relief workers during the 1933 workforce growth. A third camp was located downstream from the construction site and was known as 'Geddesville'., this was also on the lower terrace. The fourth camp was located close to the Awakino bridge and was known as the 'Willows'. However, the 'Willows' was not an official camp and was more of a shantytown of men who did some casual work and topped up their income with odd jobs ${ }^{33}$.

Accommodation was built for a total population of over $2000-350$ houses (consisting of a combined living room and kitchen, two bedrooms and a bathroom and washhouse) and 700 huts $^{34}$.

Junior married staff were allocated two bedroom wooden houses measuring 6.5 $\times 5.25 \mathrm{~m}$ and single men were accommodated in timber huts measuring $3 \times 2.3 \mathrm{~m}$ and furnished with a small stove, bed and palliase, table and stool. Married quarters for workers initially consisted of two huts placed end to end, unfurnished except for the stove. If a family was too large for the huts, another hut was added on with a covered access way ${ }^{35}$. These collections of huts were eventually replaced with timber houses.

\footnotetext{
${ }^{32}$ Ibid, p10

${ }^{33}$ Martin, J, p108

${ }^{34}$ Natusch, p11

35 ibid
} 
The senior staff were allocated permanent concrete block houses with a water supply and sewerage system, located in a separate area to the camp, that would house the station staff once construction was complete. These houses still exist across the road from the Waitaki Dam and are currently undergoing renovation to provide tourist accommodation.

The housing was provided free of charge for wage workers, but staff were required to pay small rent amounts for their superior accommodation.

In all types of housing the toilets were outside and a night soil service was provided and ablution blocks were situated in the singlemens' area. Water was provided to the ablution blocks, a tap in front of each house and to the four messes (three for the singlemen wage workers and one in the housing area for the staff) from a reservoir built above the camp ${ }^{36}$.

The existing railway line linking Kurow to the coast was extended to the site and all building materials for the camp were brought in by rail ${ }^{37}$.

Although timber was chosen as the predominant building material for the housing due to its transportability (both in its raw form and also after it was transformed into a structure), as well as its durability, timber was in very short supply in North Otago. Despite a direct rail link to the coast, the shortage was so severe that additional fence posts required on site were made of concrete (these posts, incidentally, included the first use of prestressed reinforcing in NZ in the form of prestressed No. 8 fencing wire used to strengthen the concrete, twenty years prior to the common usage of prestressing in the NZ construction industry ${ }^{38}$ ).

Although Kurow was the local service town, it was smaller than Waitaki Hydro and was not within walking distance. Lack of transport made the camp more reliant within itself to fulfil social needs than later camps and a sense of community was particularly strong when wages were cut in 1932 and many workers began living hand-to-mouth ${ }^{39}$.

\footnotetext{
${ }^{36}$ Ibid, pp11-12

${ }^{37}$ Ibid, p10

${ }^{38}$ Ibid, p11

${ }^{39}$ Natusch, p39
} 
There was a strong social separation in evidence at the Waitaki camp ${ }^{40}$. It is interesting to note that this social separation was more prevalent amongst the women than the men (who got to know each other on the job). This separation was clearly illustrated by the provision of tennis courts in the permanent village for the staff and separate tennis courts at the north of the camp for the workers (as with separation of the messes). However, both shared the other sports facilities in the camp, of which little use was made, and the children usually ignored the separations. (There was also a social distinction between the married and single workers.)

“Memories of some children seem to associate 'Boomtown' on the low terrace upstream of the dam with friends who were less well cared for ${ }^{\text {,41 }}$ but there is no evidence to substantiate claims that newcomers may have been allocated housing according to social stratifications within the employment levels.

Staff (ie: management, paid a salary and provided with superior accommodation) were either permanent PWD or temporary PWD (professionals who fulfilled intermediary positions but lacked the job security and superannuation of the permanent staff) and 'Regulation 130' men (wage-workers hired under Regulation 130 on an hourly basis, yet many found the work steady enough to follow the PWD from project to project). The 'Regulation 130' men at Waitaki came from two distinct backgrounds - the PWD regulars and the new unemployed from the towns and cities (who were expected to do the same jobs as the regulars but were not physically conditioned to the work). Many nationalities were represented amongst the 'Regulation 130' workers ${ }^{42}$.

The YMCA was the centre of social life, with dances, concerts, church services, adult education and Sunday school all held here. This is also where movies were shown, with staff sitting separately to wage workers. Despite all of this social activity, the camp, like all other PWD camps at the time, was "dry" ${ }^{43}$ and, whilst the occasional small amount of alcohol was overlooked, this was generally adhered to.

\footnotetext{
40 ibid

${ }^{41}$ ibid, p14 'Boomtown' appears to be another name for 'Siberia'

42 Ibid, pp12-13

${ }^{43}$ Ibid, p39
} 
The dam was completed and came online in $1935^{44}$. All housing and huts (except for the permanent village) were removed and little evidence of them is visible today other than the plantings.

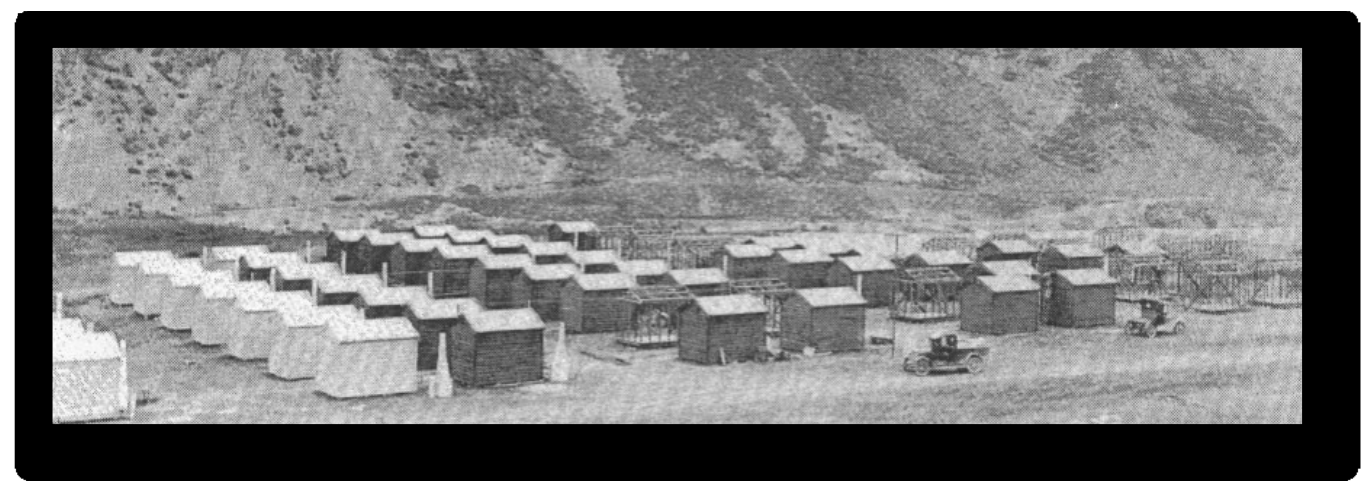

Figure 8: Singlemens' huts, Waitaki hydro village, December 1928

${ }^{44}$ Martin, J, p113 


\section{0s}

The hydro project villages are commonly referred to as "camps", a remnant of earlier projects when the accommodation was literally in camps - prior to Waitaki the huts were tents (with boards on all sides in some camps, where climatic conditions were most harsh) and a canvas roof. Bathroom and toilet facilities were outside and tenants provided washhouses at their own expense and labour. When the hydro township at Roxburgh was built a sewerage system was introduced, a toilet was placed inside each house and the houses were vastly upgraded in both size and amenities due a combination of the climate and the expected duration of the project.

By the time that Otematata was started, the roofs of the houses were clad in corrugated metal (as opposed to the malthoid previously provided) and sewerage, electricity and running water were seen as standard provisions. Electric ovens replaced coal ranges, thus making the houses fully transportable. The houses transported from Roxburgh were upgraded to meet the new standard and the village roads were tar-sealed (another first).

These changes were due in large to the introduction of families to camp life. Whereas prior to WWII the women and children usually stayed in their home towns, after WWII they began to accompany their husbands and fathers to the hydro towns as accommodation became more expensive and harder to find in the towns and cities as a result of the large number of soldiers returning to NZ in the late 1940s to a housing market heavily affected by the Great Depression followed rapidly by the shortages of WWII. Projects also became larger and longer in duration as technology allowed and the camps evolved into single purpose towns.

These factors put pressure on the Ministry of Works to provide more substantial housing and services (such as schools and commercial centres) in the hydro villages in order to draw more men into their employ. Once there, the women began to insist on the upgrade of conditions as each new project began.

There was, however, a strong social stratification in the camps of the 1950s and married wage workers did not move to a larger house (reserved for staff) as their families grew, instead a hut was placed alongside the house as needed. 
The work done on the Waitaki project in the 1950s also saw the introduction of large scale landscaping work being integrated into hydro projects in NZ. A large nursery was sited at Otematata and run by a skilled nurseryman employed by the Ministry of Works. Seedlings and trees grown at the nursery were planted throughout the well planned landscaping along the banks of the hydro lakes.

In 2001, Otematata announced a long term project plan to recreate a smaller version of a dam town as a heritage tourist attraction in the town ${ }^{45}$.This plan included repurchasing some of the singlemens' huts, to recreate life as it was in the hydroconstruction village in the late 1950s.

\footnotetext{
45"Power to the People", p1 in Employment Matters, Volume 12, Number 8, August 2001 (www.employmentmatters.net.nz)
} 


\section{Roxburgh Hydro 1949-56}

"A large model village complete with electricity, sewerage and water mains was built at Commissioners Flat, just below the gorge. Roxburgh Hydro, described as the biggest and most modern settlement in Central Otago, was built extremely rapidly, especially considering the difficulties of the post-war years ${ }^{\text {,A6 }}$

Roxburgh's origins lie in the gold rush of the mid 1800 s and by the 1870 s Roxburgh had grown to be one of the main Central Otago service centres. As in similar towns around the area, mining was gradually replaced by horticulture (led by Joseph Tamblyn in 1866) and, eventually, intensive farming.

In 1949 a site on the Tamblyns' orchard, 8 km upstream from Roxburgh, was chosen for the Roxburgh hydro dam. This site was not only chosen because of its suitability for a higher head and better tailrace conditions than the other options, but also because there was suitable flat land at the site for a construction village and the site was close to the existing Roxburgh service centre ${ }^{47}$.

The MoWD built a construction camp of transportable houses at Roxburgh which was the first hydro town in NZ with a sewerage system, as well as water and electricity to all houses. This village consisted of 700 single mens' huts and over 700 houses and cost $£ 1,000,000^{48}$.

By 1951 though, work was falling far behind schedule and the Labour government agreed to let contracts to the British construction firm of Holland and Hannen and Cubitts and the Swiss electrical firm S. A. Conrad Zschokke ${ }^{49}$. This consortium brought 82 English and Swiss staff and 322 workmen with them. This aided the project mightily as the main reason for its lack of performance to date had been the shortage of labour in NZ. The introduction of this many new workers meant a great increase in the size of the village. (In contrast, the introduction of A. F.

Downers into the consortium in 1954 led to higher productivity and yet a decrease in workers. $)^{50}$

\footnotetext{
${ }^{46}$ Martin, J, p 270

${ }^{47}$ Ibid, p 269

${ }^{48}$ Campbell, p5

${ }^{49}$ Martin, J, p 271

${ }^{50}$ Martin, J, p 272
} 
By 1954 there were over 1100 men employed on the project, of which 446 were New Zealanders, 340 were English, 58 were from the Republic of Ireland, 20 were from Northern Ireland, 28 were from Scotland, 18 were from Switzerland and the vast majority of the rest were from other European countries ${ }^{51}$. These numbers varied throughout the project cycle but the inclusion of immigrants who were "directed" to the project for two years on arrival in NZ (particularly from the UK, Eire and Holland who arrived under the Assisted Immigration Scheme) was a constant source of cultural diversity.

The population of Roxburgh hydro village reached 3,120 at its peak in the mid1950s. By this time there were 4 single mens' camps, cookhouses, YMCAs, over 700 houses for married men and staff, a social hall, post office, ten shops, cinema, library, community centre, TAB, several churches, a doctor and a dentist and a primary school with a roll that reached 550 .

The tents which were predominantly used previously in hydro towns to house single men were replaced here with huts (as at Waitaki) measuring $3.0 \times 2.4 \mathrm{~m}$ (10x8ft). Each hut had a stove, bed, table and stool, with a bare interior lining left for decoration by the occupant.

In contrast, there was variation in the designs of the houses, reflecting the occupation of the inhabitants. The houses for married wage workers were $48 \mathrm{sq} \mathrm{m}$ (520 sq ft). These were clad with weatherboards and had malthoid roofs with no spouting. Inside were two bedrooms, a living room with a small adjoining kitchen (with coal range), a laundry with two tubs and a bath and separate toilet. As there were only two bedrooms in each house, as the family grew it was necessary to apply for a singlemens' hut to be placed alongside the house to accommodate further children. The interior of these houses was left as bare pineboard for the occupants to decorate themselves. 2/- per week (roughly a third of the average hourly wage) was charged for the hire of the water heater in these houses (this was not standard MoWD house equipment) but no rent was charged for the houses ${ }^{52}$.

\footnotetext{
${ }^{51}$ Campbell, p 17

52 ibid, p6. However, Marion Sheridan seems not to agree with this, suggesting that workers were charged 10 shillings per week for these houses (Sheridan, p8). I have chosen to rely on Campbell's
} 
Some MoWD staff and professional people not employed in construction were provided with three bedroom, $76 \mathrm{sq} \mathrm{m}$ (820 sq ft) versions of these houses on Bendigo Crescent and the most senior of the staff were provided with $93 \mathrm{sq} \mathrm{m}$ (1000 sq ft) houses on Teviot Street and Sandy Point Road, both of which were more attractive in outer appearance than the workers' housing ${ }^{53}$. Rent was charged on these houses according to salary and the cookhouses (which provided mainly for the single men) charged 35/- per week for three meals a day.

The sections on which houses were placed were mostly $30.5 \mathrm{~m} \times 18.3 \mathrm{~m}$ (100ft $\mathrm{x}$ $60 \mathrm{ft}$ ) and predominantly flat. The huts were placed on both hill and flat.

Neither the houses nor the huts were fully transportable as, once in place, brick chimneys were added for the wood stoves and these needed to be carefully removed before transportation of the buildings.

On 21-22 June and 28-29 June 1956 a clearance sale was held on site. Amongst the 2,875 lots were some of the houses and huts. The rest were dismantled (where necessary) and transported to Otematata, despite being "not built to last for much more than ten or fifteen years ${ }^{54 "}$

direct reports from site rather than the fact that Sheridan was writing her account many years after leaving Roxburgh

${ }^{53}$ Campbell, p5

${ }^{54}$ Campbell, p6 


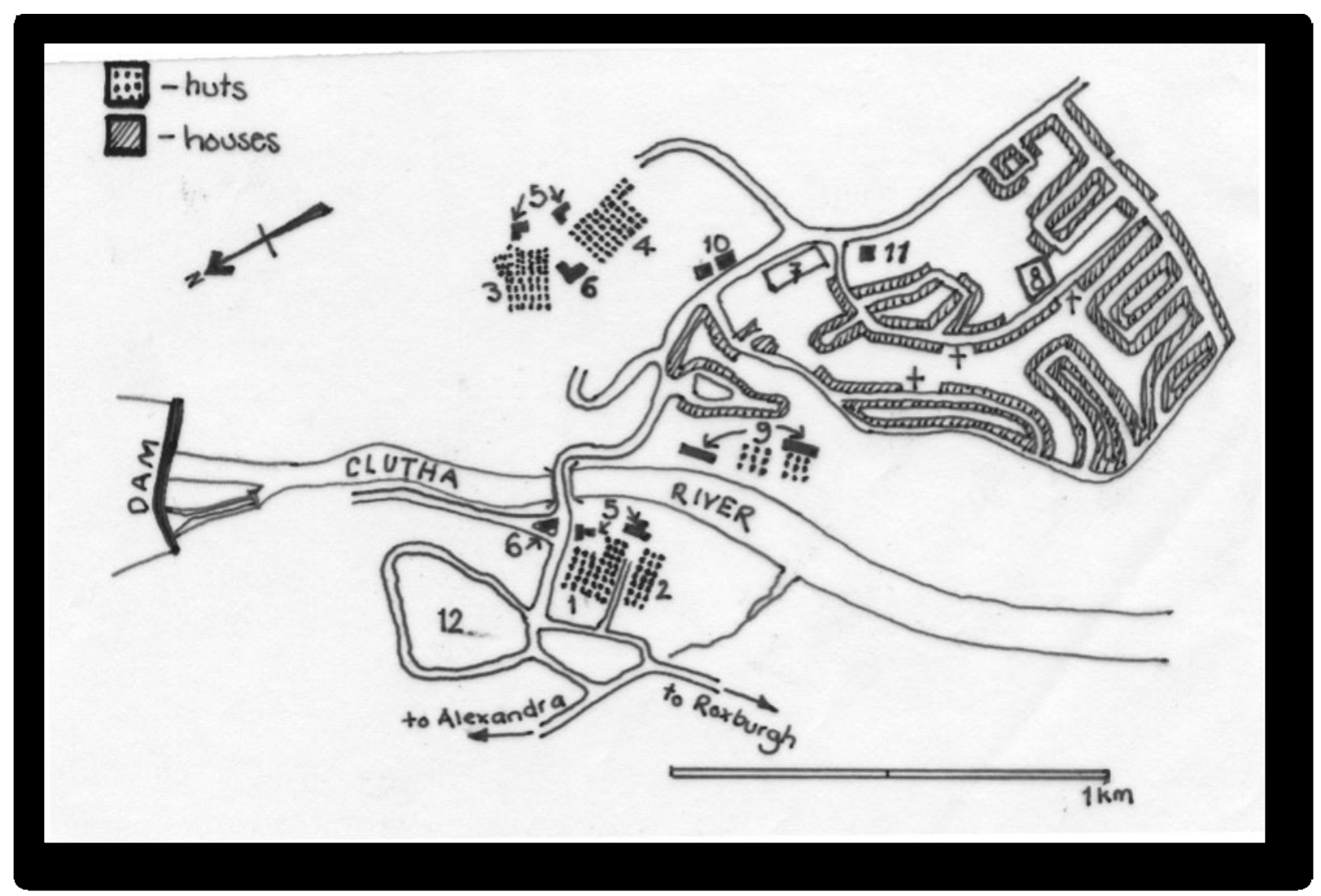

Figure 9: Roxburgh Hydro Village town plan

1 - Singlemens' Camp No. 1

2 - Singlemens' Camp No. 2

3 - Singlemens' Camp No. 3

4 - Singlemens' Camp No. 4

5 - Cookhouses

6-YMCAs

7 - Shops, Cinema, etc 8 - School

9 - Consortium Hostels

10 - Ambulance and Fire Brigade 11 - Police

12 - Permanent houses

Shaded areas - family housing

Dotted areas - singlemens' huts 


\section{Otematata 1956-71}

"Coming from Roxburgh into the new terrain was like "walking from the doldrums into paradise ${ }^{\prime \prime \prime 55}$

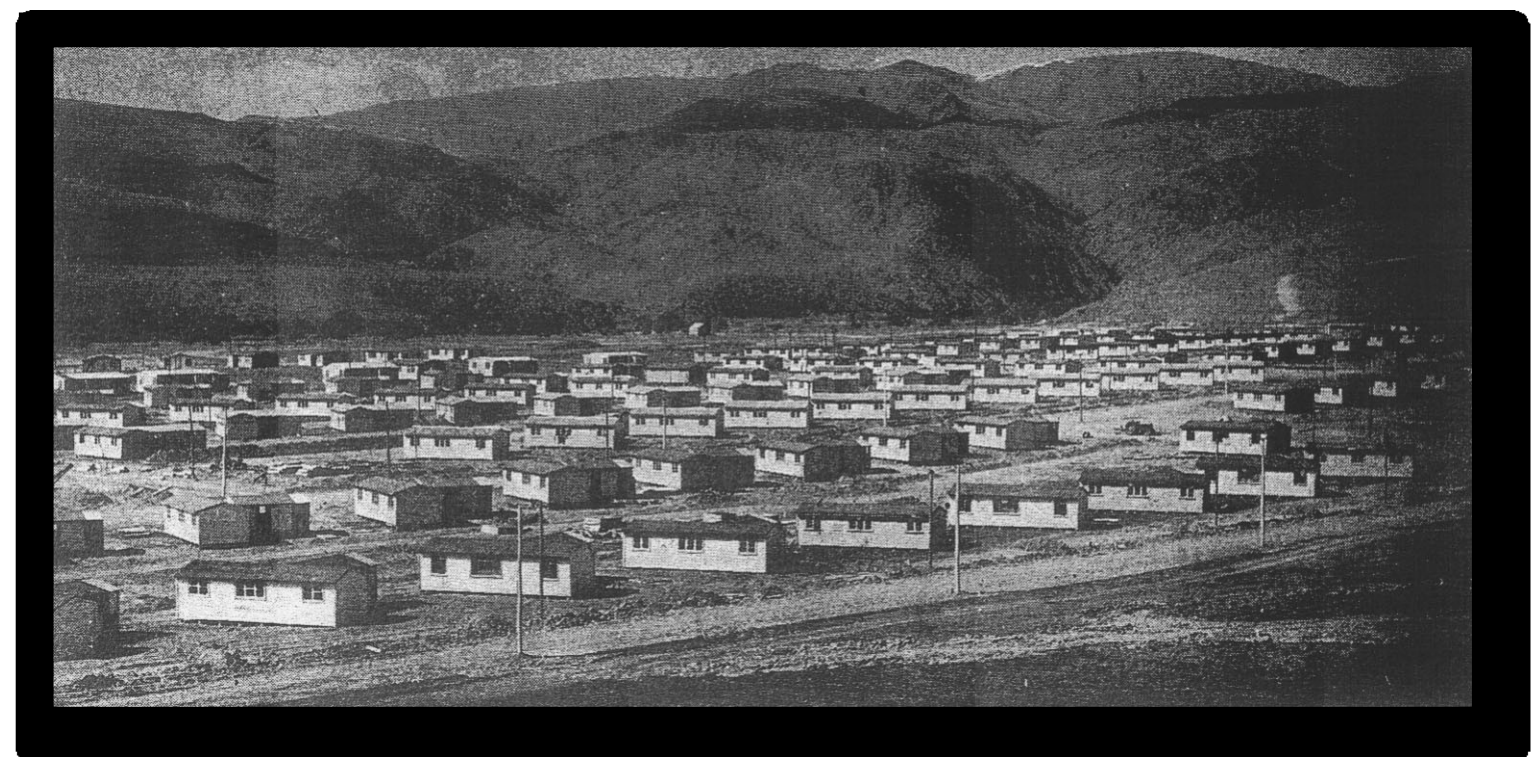

Figure 10: Otematata, 1958

While Otematata did not begin construction until the end of the 1950s, prospered through the 1960s and was finally sold off in the early 1970s, it has been included in the 1950s section as this is when the planning and design for the township and housing took place.

The survey for the Benmore dam began in February 1956. Wives and families began to follow those surveying the project in early 1957 . They were settled at Snake Gully in houses that had Coleman lamps (as there was no electricity) and a coal range. There was no wash house or toilet facilities. In the first winter the water supply and the ground froze (making digging of toilets very difficult) ${ }^{56}$.

A contractors' camp was set up at Sugar Loaf Creek soon after this and, in 1957, the MoWD announced that another hydro village was to be constructed at Otematata, beginning immediately, for workers on the Benmore (1957-65) and

\footnotetext{
${ }^{55}$ Sheridan $\mathrm{p} 10$

${ }^{56}$ Ibid, p 93
} 
Aviemore (1962-68) dams. At this stage there were only 10 MoWD staff and 30 workers on site with very little machinery ${ }^{57}$.

Following the announcement a fleet of nine trucks was assembled to begin transporting the available housing and huts from Roxburgh and re-siting them on preserviced sections. This involved hauling the accommodation 125 miles $(200 \mathrm{~km})$, part of which was over the Lindis Pass.

The houses began to arrive in August 1958 and as buildings arrived on site at Otematata they were unloaded by mobile cranes and placed on concrete piles, though not tied down to these. At the same time the streets were set out and tarsealed.

The houses transported from Roxburgh were upgraded (in all, 437 were transported from Roxburgh in two years, along with 400 huts) and many more were built to match in the carpenters' shop in the industrial area of Otematata. The malthoid roofs were covered with corrugated iron sheeting, electric ovens were installed to replace the old coal ranges and there was a separate bathroom and toilet inside each house. The interiors were decorated prior to occupation, yet occupants were once again left to landscape their own sections and provide their own washing lines. These houses were known as "regulation 130" houses and were T-shaped (see fig 10).

These houses had no insulation and, if not heated, the contents of the house froze. All heating had to be electric however, as the transportable nature of the buildings meant that there were to be no chimneys or flues. The houses froze in winter and were very hot in mid-summer. The temporary nature of this housing was especially evident when placed next to the brick veneer homes of the Electricity Department (NZED) staff.

As soon as the majority of housing for immediate need was in place, the school was transported from Roxburgh village to Otematata, as was the YMCA canteen (which was to be the first NZ Workers Union-run canteen in New Zealand).

In December 1957 the Licensing Control Commission authorized the grant of a publican's licence to the township and, later, a five star hotel was to open across the

${ }^{57}$ ibid 
highway, making Otematata the first hydro camp to not be declared "dry" (ie:.no alcohol allowed on site).

The services at Otematata were pretty similar to those that had been at Roxburgh - social hall, doctor, a dozen shops, a bank, a post office, a TAB and the hotel were all operating by early 1959 , and the shopping centre was acting as a common meeting place for the mothers ${ }^{58}$.

Once housing from Roxburgh began to fall into short supply, buildings began being transported from Hawea, another Ministry of Works hydro project, close to Wanaka. The hostel from Hawea was also relocated to Otematata and provided consistency in housing for 16 MoWD staff members (single staff lived in hostels, while single wage workers lived in huts).

Once again the singlemens' huts were separated from the housing area, this time by a highway, and were supplied with canteens and cookhouses and shared bathroom facilities (see fig 11).

In September 1959 tenders closed for construction of a single womens' hostel, the first of its kind.

By the end of 1965, the population of Otematata was at its peak of around 5,000 (900 wage workers, 270 MOWD staff and 130 NZ Electricity Department staff) housed in 650 houses and two singlemens' camps of a combined 550 huts. There were three different sizes of house (520, 820 and $1000 \mathrm{sq} f \mathrm{ft}$ ), allocated according to the occupant's position on the project.

As an indication of the unusual composition of the population of this town, of the population of 5,000, 540 were enrolled at Otematata District High School and 430 were enrolled at Benmore Primary School.

As at Roxburgh, these houses had only two bedrooms, so it was again necessary to apply for a hut to be placed alongside the house as the family grew. As can be seen by the school enrolment numbers, many families were in need of more than two bedrooms and this sometimes led to as many as three huts being placed

${ }^{58}$ Sheridan, p 12 
on a section alongside a "regulation 130" house. Some men built passageways to join the huts to the house ${ }^{59}$.

In 1967, work on the dams was nearing its completion and the idea of retaining part of Otematata was raised by the occupants. This eventually led to the handover of 96 acres, including 250 houses and a permanent population of 180 Electricity Department staff, to the Waitaki County Council ${ }^{60}$.

The Waitaki County Council paid the Lands and Survey Department to purchase the half of Otematata that was to remain and it took over all community services, including water supply, sewerage, plant and reticulation on October $1^{\text {st }}, 1971$, when Otematata officially became a county town. Most of the balance of the housing had been earmarked for transportation to Twizel and all remaining "regulation 130" houses and sections were sold to the public as holiday houses, at an average of $\$ 850$ each $^{61}$.

While the negotiations to begin the project at Twizel dragged on, many men were left unemployed with Benmore and Aviemore complete and no project to go to. Many moved to Manapouri to start on 1MTT, but there was little housing for families in the region, so many of the married wage workers chose to stay in the region, awaiting the move to Twizel ${ }^{62}$.

Since 1971 Otematata has continued to survive with a permanent population of $243^{63}$ and many more houses are retained as holiday homes. There are also quite a number of newer homes built on sections that "regulation 130" houses had been removed from.

While the layout of Otematata still advertises its beginnings by its uniformity of orientation and planning, it is very interesting to note the lengths that the owners have gone to over the last 40 years to make these homes more individual. Porches, conservatories, decks, additions of all manner and form as well as new claddings, colours and joinery have been introduced to varying degrees of success. As one drives down the streets of Otematata today, there is a strongly pervading sense of

\footnotetext{
${ }^{59}$ Sheridan, p 10

${ }^{60}$ Ibid, p 20

61 ibid

62 Ibid, pp 98-99

63 in the 2001 Census, down 117 since the 1996 Census
} 
rejection of one of the main briefs of the creation of this housing - that it be the same for all workers (excluding management).

All that remains of the once bustling shopping area on the south side of the highway is a camp store and one general store. The hotel is still operating on the north side of the highway, catering mostly to holiday makers visiting the Waitaki River and Lake Benmore. 


\section{THE DAM DWELLERS}

By Marion Sheridan

This is a tale of achievement and wonder, Pride amongst men and hopes torn asunder. People and power that governments borrow, The scorn of today, the dreams of tomorrow.

This is our village of people and faces, All leaving now for far away places. Leaving behind them the echo of grief, Urging authorities to turn a new leaf.

The Welfare dispersed, amusements diminished. Dismayed were the children, their films were now finished.

Then the dentist packed kit, took flight in the night, And the doctors went west to take up their plight.

Then came the news that confirmed all our fears, Destroying the bond that had strengthened through years.

By man's toil and sweat these structures did grow, Yet with burdens so heavy these men had to go.

The Chronicle news then made its decision, To make May the $2^{\text {nd }}$ its final edition.

Shops soon stood idle, the customers few, Farewell to the old life and herald the new.

Houses stand empty, the windows are bare, Gardens once flowered devoid now of care. The echoes of laughter washed up on the shore, For here lies the ghost of the "hard working core".

Partings are many, friendships thus mourn, Turning backs on the town where their children were born.

Our pleas were unanswered and efforts in vain, Where now lies our future? What price was their gain?

Yes, this is our story and now it's too late, Decisions unwelcome have thus sealed our fate. And yet through this sadness we'll always remember,

Our homes and our town in its last dying ember. ${ }^{64}$

${ }^{64}$ Sheridan, p19 


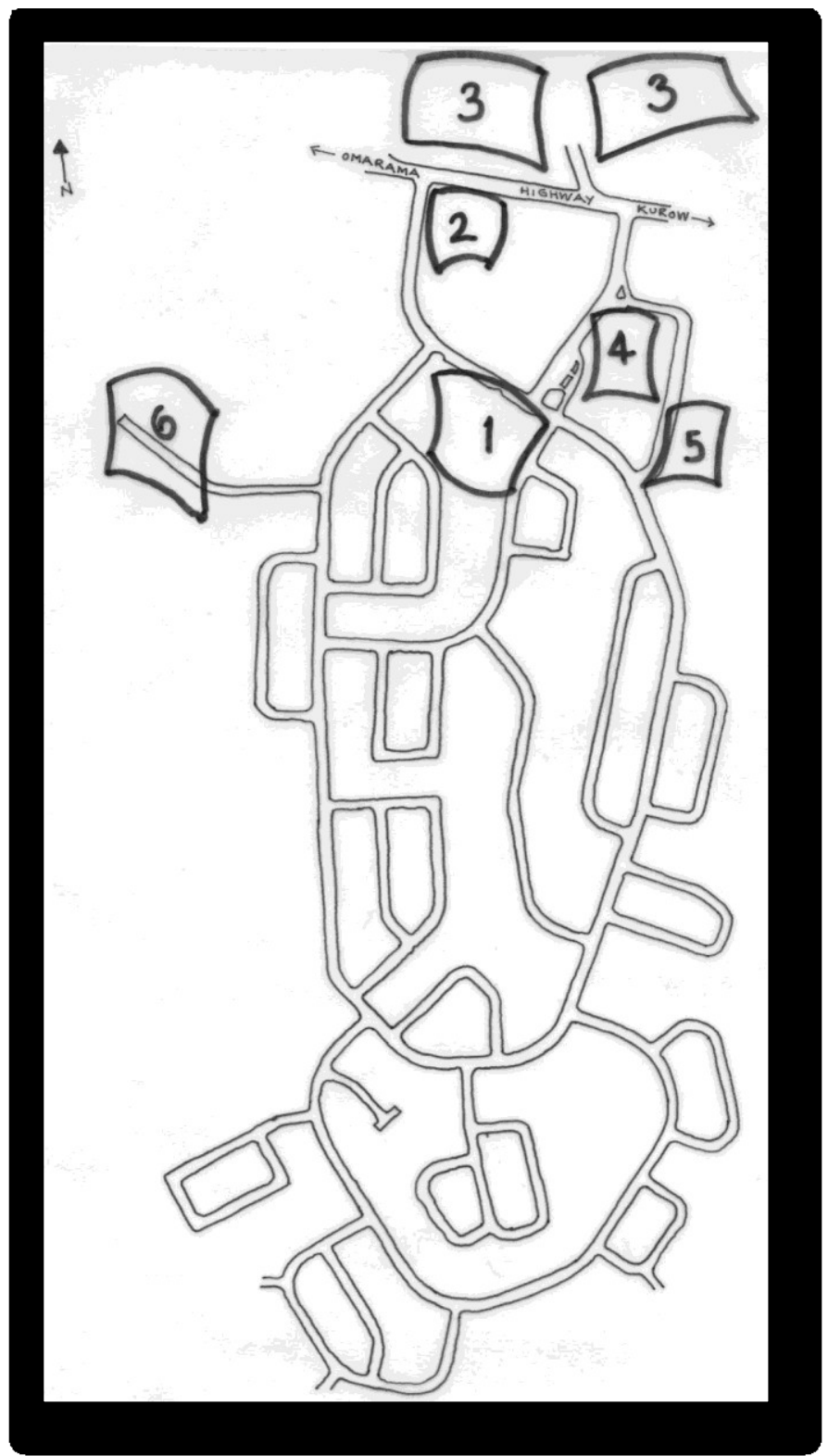

Figure 11: Otematata Town Plan, 1960s

1. Shopping centre

2. MOWD Offices

3. Singlemens' huts

4. Hostels

5. Top tier management*

6. Second tier management*

*Note: some management occupied other areas throughout township, housing location did not usually have the same social stratification as it had had at previous camps 


\section{0s}

The 1960s in America brought a fashion for mobile homes. They were seen as an affordable step up towards owning a permanent home. They were not seen as a permanent housing solution in their own right though. While it was fashionable to own and live in one as a young married couple, it was not seen as desirable to stay in one through to middle age.

The main reason for this trend was that they offered an opportunity for a young married couple to move out of their parents' homes, as this had been previously difficult with both a housing shortage and low wages and it was often not until a couple began to have children that they were expected to leave home.

All forms of transportable housing were also popularised later in the decade by the hippie movement. Houseboats, housetrucks, tepees and other multi-cultural vernacular transportable housing types became popular with this movement along with contemporary forms. However, once again this transportable housing popularity came with strings attached - this time it was seen as desirable for its transformability, transportability, low cost and its lack of conventionality rather than as a permanent housing solution (ie: it was a reaction against society).

Meanwhile, Archigram had been widely broadcasting its views on transportable buildings (and cities, such as Peter Cook's Plug-In-City, published in 1964) as the future of architecture. Then, in 1967, the architectural world was forced to take further notice of transportable environments with the US pavilion at the Montreal Expo by Buckminster Fuller and also Frei Otto's involvement in the main pavilion. Both were partially in response to the 1962 earthquake in Friaul, Italy, and the immediate massive housing need that it created in that region.

In NZ a new take on the traditional hydro construction village was required at the Deep Cove site for 1MTT. Prior to construction of the road over the Wilmot Pass, the accommodation had to be brought into Deep Cove by boat via the Tasman Sea and Doubtful Sound. It took the more liberal thinking Americans to solve the problem with the introduction of the TSMV Wanganella in Doubtful Sound. 
The remoteness of the sites of 1MTT also excluded the ability of wives and families to live with the men. This had an unexpected effect in vastly reducing the social stratification previously dominating the hydro camps.

Although huts were utilised alongside the Waganella and at West Arm, and conventional housing was placed at Manapouri later in the project, the Wanganella seemed to signal a break in the way that the hydro camps were designed. Although too late for Twizel, the camps which followed were vastly different to those that preceeded it. 


\section{Manapouri Tailrace Tunnel 1963-69}

"I've never been on a job like this one. In fact, I doubt if anyone ever has. It would be fairly easy, if it weren't for the rain, mud and vegetation."165

Curly Mauzy, Superintendent at West Arm

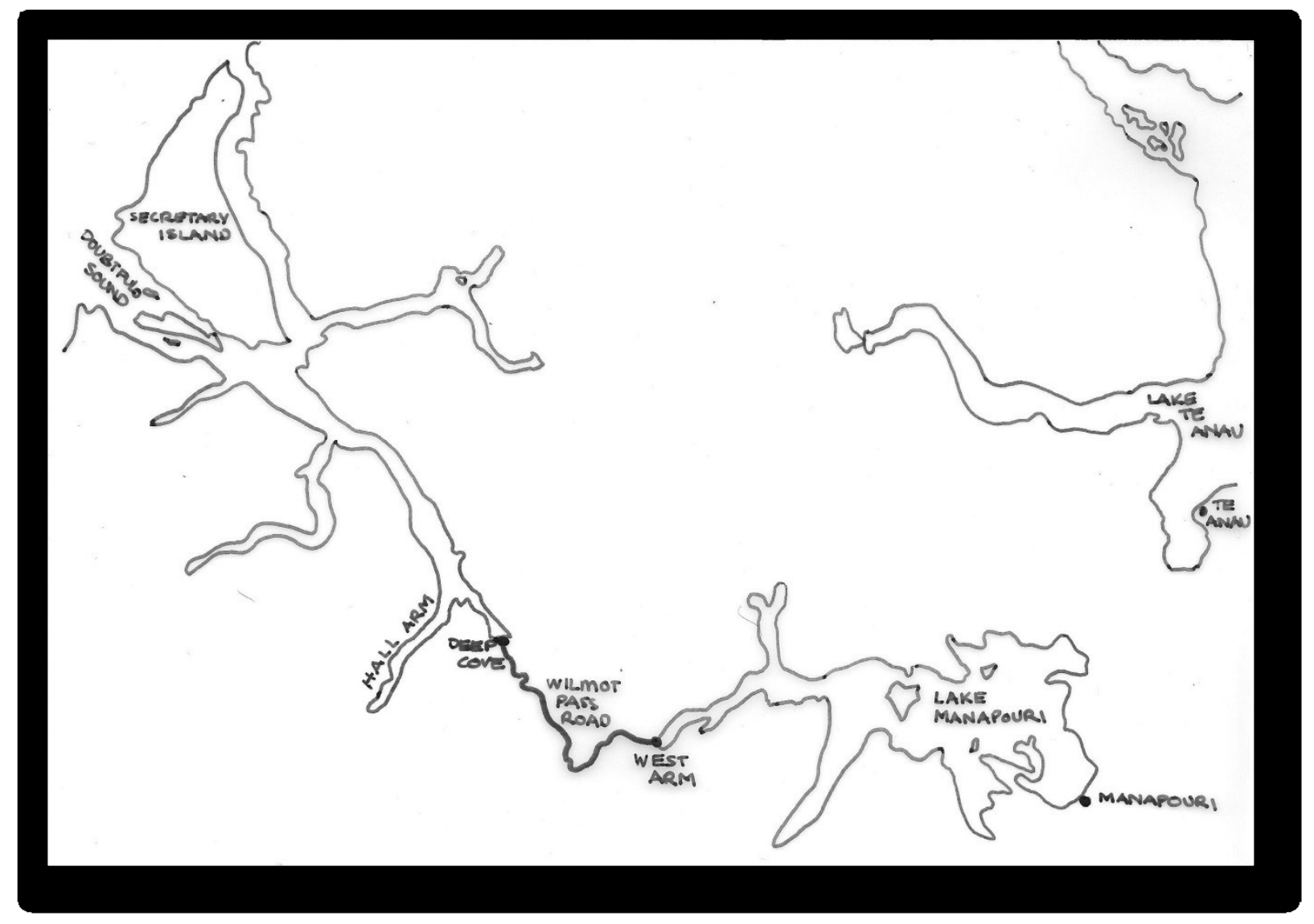

Figure 12: Map of Tailrace Tunnel accommodation locations

${ }^{65}$ Howard, Power From Fiordland, p43 


\section{West Arm}

West Arm was the first camp constructed for the $1 \mathrm{MTT}$ project. The contractors had to clear the thick native bush at the lakefront for the camp and, as at Deep Cove, the bulldozers often sank into the bogs and made progress at a very slow rate $^{66}$.

West Arm is, however, not as isolated as Deep Cove and the prefabricated buildings were comparatively easy to barge across the lake and put in place once the site was cleared (see fig 13). Fiordland Travel (now known as Real Journeys) operated barges to transport the camp, which eventually housed several hundred people.

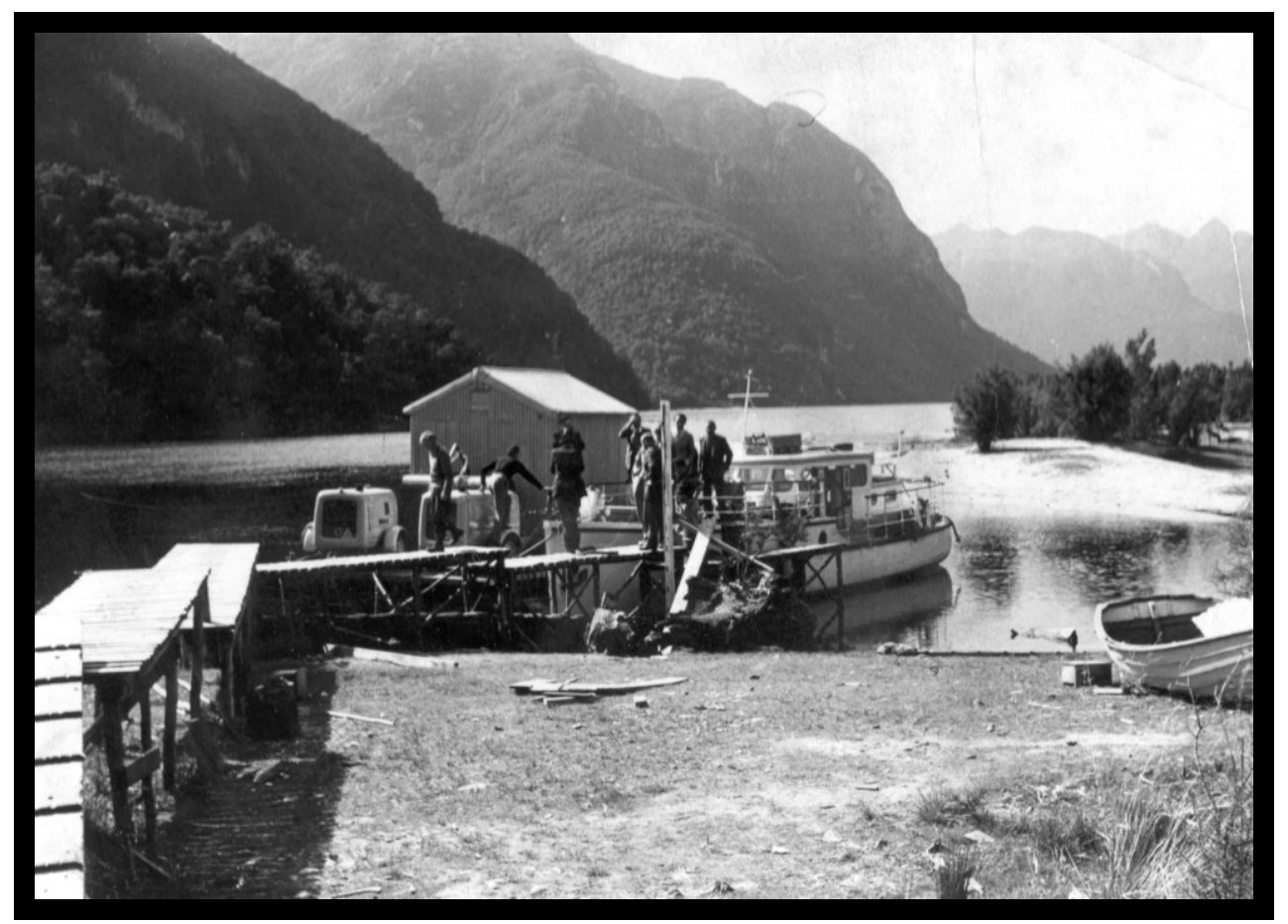

Figure 13: The first hut being delivered to West Arm, 1963

The huts were stand alone $3.6 \times 2.4 \mathrm{~m}$, with infra-red heating, an electric light, a power point, a chest of drawers, a writing table and chair and a bed, in the tradition of previous examples.

\footnotetext{
${ }^{66}$ Howard, Power From Fiordland, p 44
} 
A hostel was also brought in from Lake Gunn, near Invercargill. Part of it had been burnt down and the rest was initially transferred to West Arm as singlemens' accommodation (it is now located at Te Anau Holiday Park and used for backpacker accommodation). The rooms are larger than those provided in the lodges/hostels at West Arm in the 1990s, but lack the insect screens and ventilation. A small amount of smoke damage is still evident.

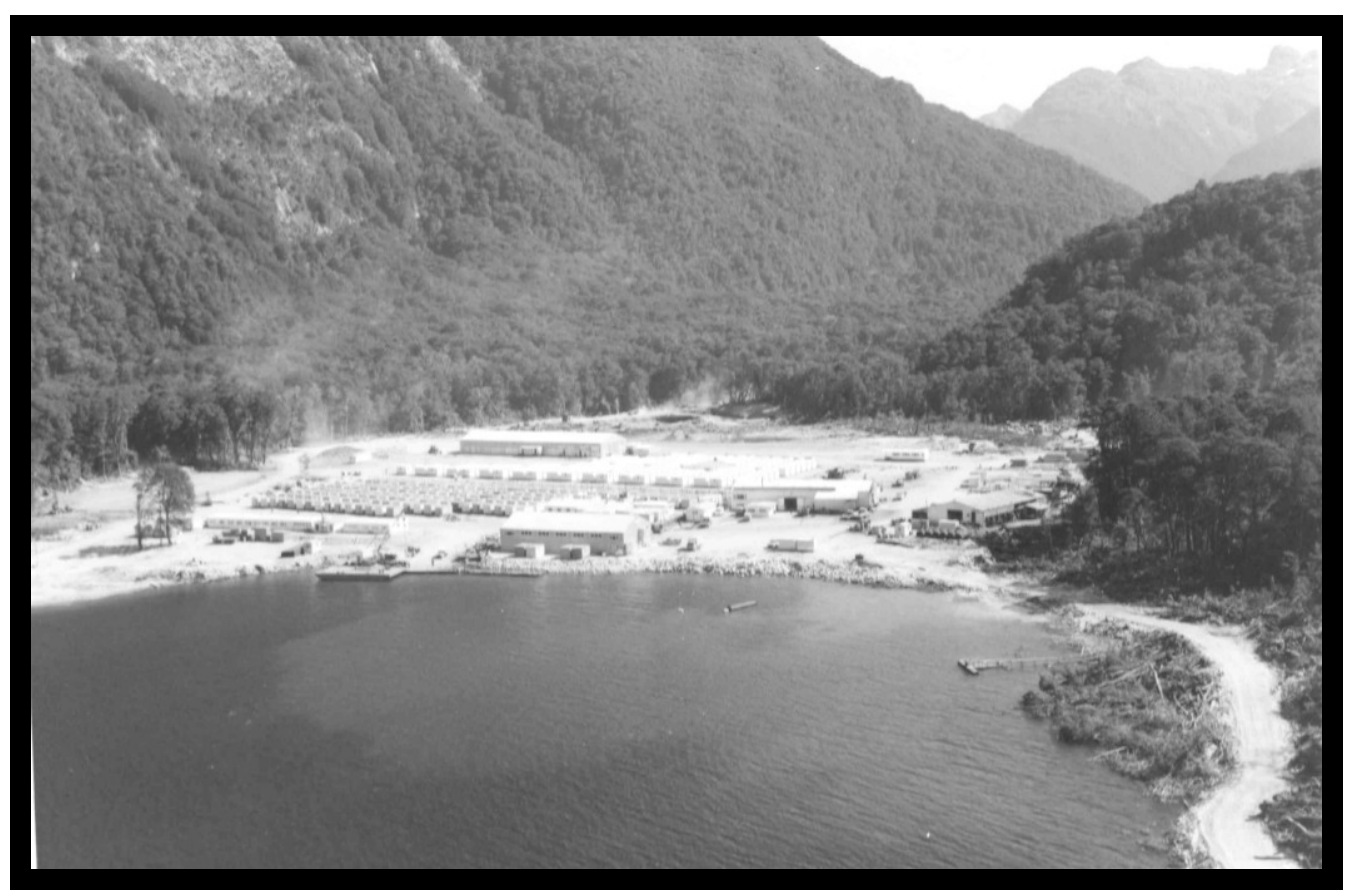

Figure 14: The camp at West Arm, 1MTT

Some of the huts which housed the workers at West Arm were later purchased by Manapouri Holiday Park and have been renovated and individualised to provide tourist accommodation. Also in place at Manapouri Holiday Park is an ablution block from the camp. 


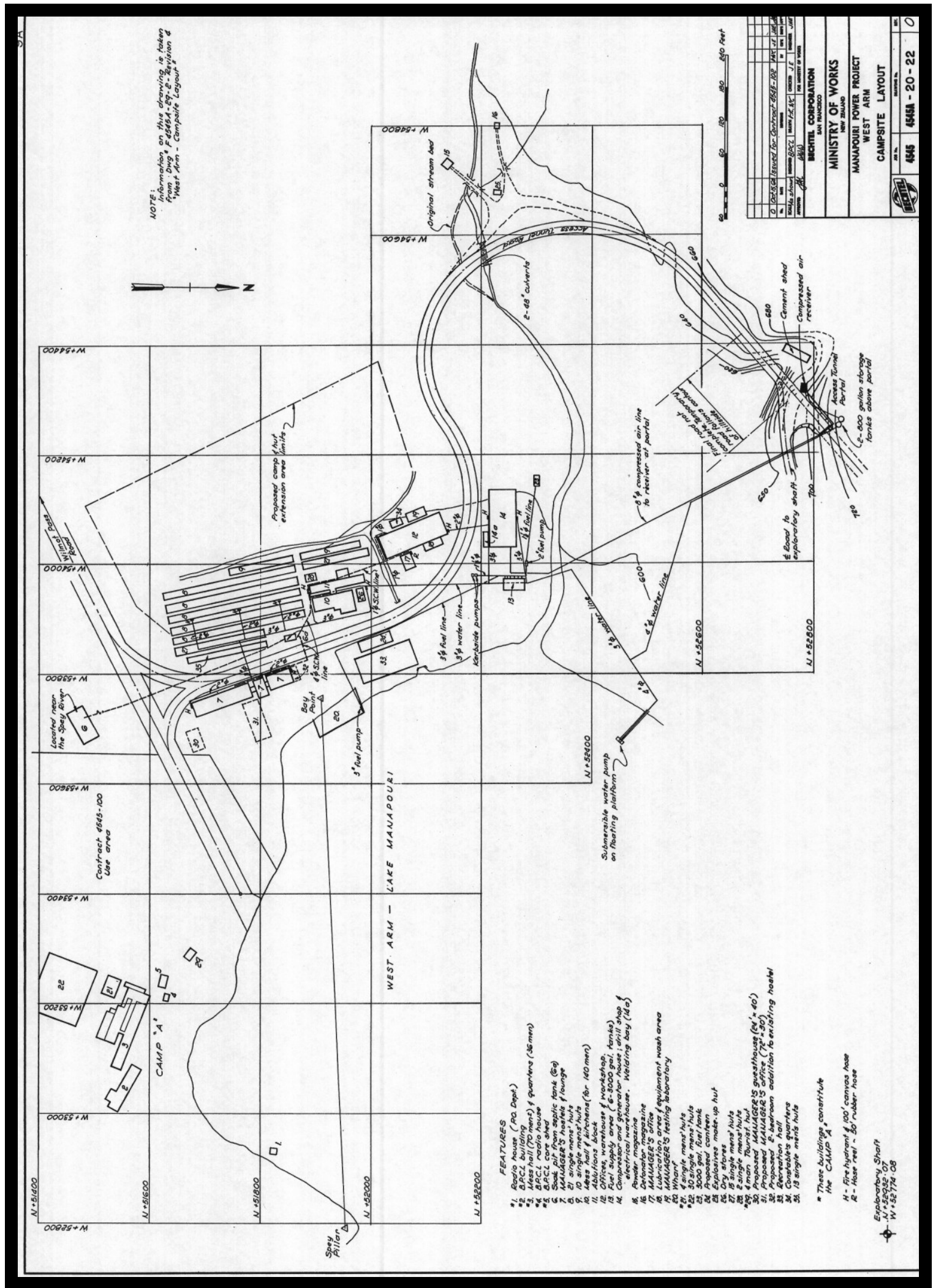

Figure 15: Original plan of West Arm camp layout, 1MTT 


\section{TSMV Wanganella}

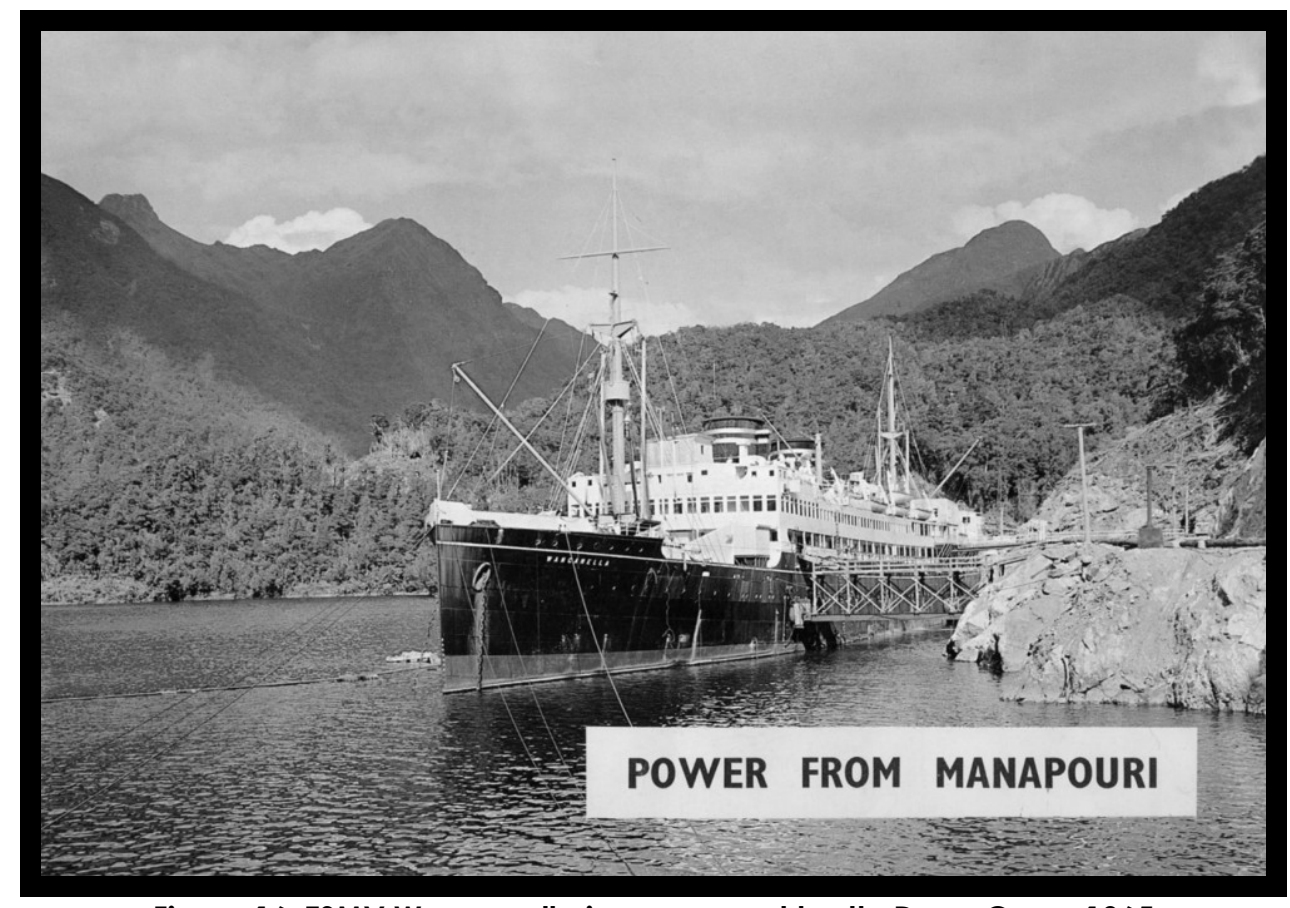

Figure 16: TSMV Wanganella in permanent berth, Deep Cove, 1965

The Wanganella was the most popular ship on the trans-Tasman run in the 1930s, she was beautifully appointed and also fast. Then, in 1941, the Wanganella was taken over by the Australian government and converted to a hospital ship. After WWII she was refurbished and began trans-Tasman passenger runs again but she was no longer the fastest on the run and she was also no longer the most glamorous.

In 1962 she was transformed into a floating hotel and located at Fremantle, Western Australia during the Perth Empire Games of November 1962. Once the Games were over, she was laid up and placed on the market ${ }^{67}$.

The Utah Construction and Mining Company and the Bechtel Corporation, working in joint venture on the Manapouri project, purchased the Wanganella in July 1963 to be used as an alternative to building a construction camp at Deep Cove. She was also to be used as a floating dock for loading and unloading of materials and stores (with the use of her derricks), as there was no wharf at Deep Cove yet.

${ }^{67}$ Bennett, p 14 
The Wanganella arrived in Deep Cove on $1^{\text {st }}$ September, 1963. Unfortunately she arrived before all of the anchoring ring bolts had been sunk into the rock faces to tie her to. As a result, some of her mooring ropes had to be fastened to trees ${ }^{68}$.

Conversion of the ship into a camp began with the Wanganella's silver cutlery, and any other item declared unnecessary for camp life, being removed ${ }^{69}$. She was then fumigated (no doubt much to the horror of the environmentalists who considered that this job should have been done prior to the Wanganella being tied up as she doubtlessly introduced numerous vermin into the Fiordland National Park), twin berth cabins were converted into single berth cabins, a concrete floor was laid over the grease in the galley and numerous other modifications were made ${ }^{70}$. A six bed hospital was built onboard the ship and staffed with a doctor and two nurses (the only women allowed on board the Wanganella overnight - special self-contained quarters were built for the nurses at the aft of the ship). Once the modifications were complete she was capable of accommodating 474 men and feeding $620^{71}$.

A gang of cleaners was employed to continuously clean the ship and to load and unload stores and cargo from ships berthing alongside. All rubbish was supposed to be disposed of at sea, which required a boat trip of approximately $30 \mathrm{kms}$ down the Sound, for which a converted lifeboat was used. Unfortunately, often the lifeboat was towed around the corner into Hall Arm instead and the rubbish was dumped there rather than face the long journey in bad weather ${ }^{72}$.

Isolation, very few entertainments, an average rainfall of around 6 metres per year and huge numbers of sandflies combined to make life difficult for the men in Deep Cove. To relieve some of the boredom and stress, No1 hold was converted into a theatre. Boxing tournaments were also introduced and often shows travelling in the area were persuaded to include a performance on board the ship.

In the first 17 months the only contact between the ship and shore was a launch ${ }^{73}$. There was no jetty at the shore end, which meant that every trip to shore or

\footnotetext{
${ }^{68}$ Meridian, "Technology and Teamwork", p 9

${ }^{69}$ Bennett, p 18

${ }^{70}$ Ibid, p 18

${ }^{71}$ Stolz, p 27

72 Bennett, p 21

${ }^{73}$ Ibid, p 22
} 
ship required getting wet at the shore end. A drying room was provided so that the men could leave wet clothes somewhere other than in their cabins, but the situation was still far from ideal.

In February 1965 the ship was finally winched into her permanent berth, a year and a half after she had arrived at Deep Cove. Access to the ship was made much easier with two pivoting gangways which also allowed trucks to be driven onto the ship to load stores and equipment. At the same time a change house was built on the shore and joined to the ship via a covered walkway, which allowed the men to come aboard in dry clothes (see fig 17$)^{74}$.

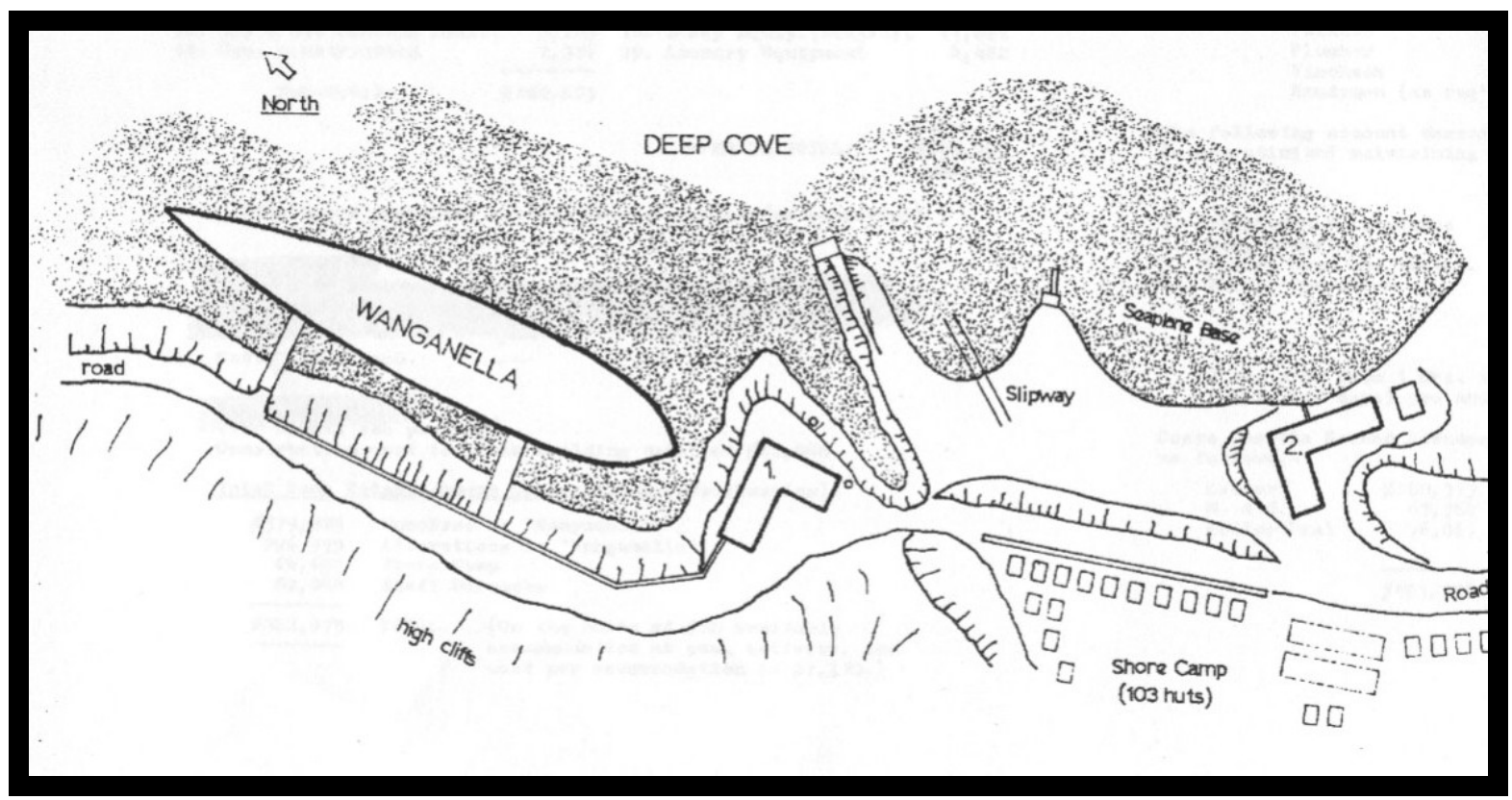

Figure 17: Plan of Wanganella at permanent berth, Deep Cove

1.Change House

2.Staff hostel

To everyone's relief, the permanent berth meant not only direct shore to ship transfer of passengers, but power was now supplied by the construction powerhouse ashore (as opposed to shipboard generators) and fresh water came aboard directly from a mountain stream, both allowing for a guaranteed continuity of supply that was not in place previously ${ }^{75}$.

\footnotetext{
${ }_{75}^{74}$ Bennett, p 24

${ }^{75}$ Howard, The Heart of Fiordland, p 193
} 
The occupants now had a dining room (though meal quality did suffer a little when bad weather delayed supplies), a library, "wet" and "dry" canteens, a post office, a huge gym for indoor sports, a hospital and a theatre on board. The sleeping cabins were also warm and dry ${ }^{76}$.

Although there were up to 27 nationalities living on board at any one time ${ }^{77}$, the vast majority of the occupants were more than happy with their accommodations. One worker said "the Wanganella is the finest Works camp that's ever been created anywhere in New Zealand. It's all under one roof - everything. It's home to me and I'm always glad to be back" ${ }^{\prime \prime 8}$.

Another step forward in the evolution of MoWD camps was undeniably the dining room which required everyone to eat together - staff and wage workers. This, combined with the lack of women on board (traditionally the greatest exponents of the class system in the camps), broke down a lot of barriers and greatly reduced any social distinctions and tensions.

No alcohol spirits were allowed on board (though they were often smuggled back after leave), which meant that there was a huge amount of beer drunk in the boat deck bar (and the tin cans were dumped over the side, in the knowledge that they would break down fast in the sea water ${ }^{79}$ ). In honour of the amount of beer drunk in both the Deep Cove and the West Arm camps, Steinlager provided special cans for the two camps (see fig. 18). This provision of separate faceplates for the beer was also a further reminder of the separation of the workforces. The Utah Construction and Mining (UCM) workforce (building the underground powerhouse and the shafts for the water intakes and power cables) were housed at Manapouri and in the huts at West Arm. The UCM, Williamson Construction and Burnett Motors consortium (UWB) workforce (building the tailrace tunnel, Wilmot Pass road and Deep Cove wharf) were housed in the Deep Cove shore camp and on the Wanganella ${ }^{80}$.

\footnotetext{
${ }_{77}^{76}$ Howard, Power From Fiordland, p 42

${ }_{78}^{77}$ Bennett, p 27

${ }^{78}$ Howard, Power From Fiordland, p 41

${ }^{79}$ Bennett, pp 28-29

${ }^{80}$ Hutchins, p 93
} 


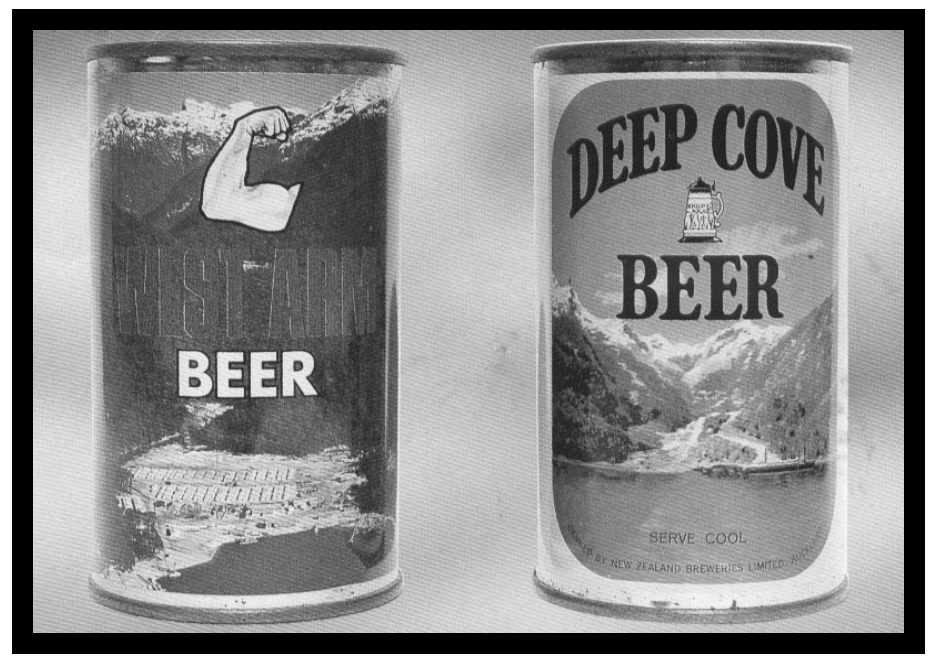

Figure 18: Steinlager in special cans supplied only to the $1 \mathrm{MTT}$ project

(Photo courtesy of Manapouri Holiday Park)

The last comfort to be introduced to the ship was a telephone service. While previously the only contact from ship to elsewhere was by radio to Invercargill or by plane. With the introduction of a line over the Wilmot Pass, it was now possible to call West Arm, have the call radioed across to Te Anau and then transferred back into the telephone line to its destination. Unfortunately this line was vulnerable to interference as it was above ground and it was frequently disrupted by deer and possums ${ }^{81}$.

In 1969 the project was completed and the Wanganella was declared redundant. She was towed away April $14^{\text {th }}, 1970$, and taken to Taiwan for demolition ${ }^{82}$.

\footnotetext{
${ }^{81}$ Howard, Heart of Fiordland, pp 197-8

${ }^{82}$ Bennett, pp 31-33
} 


\section{Deep Cove}

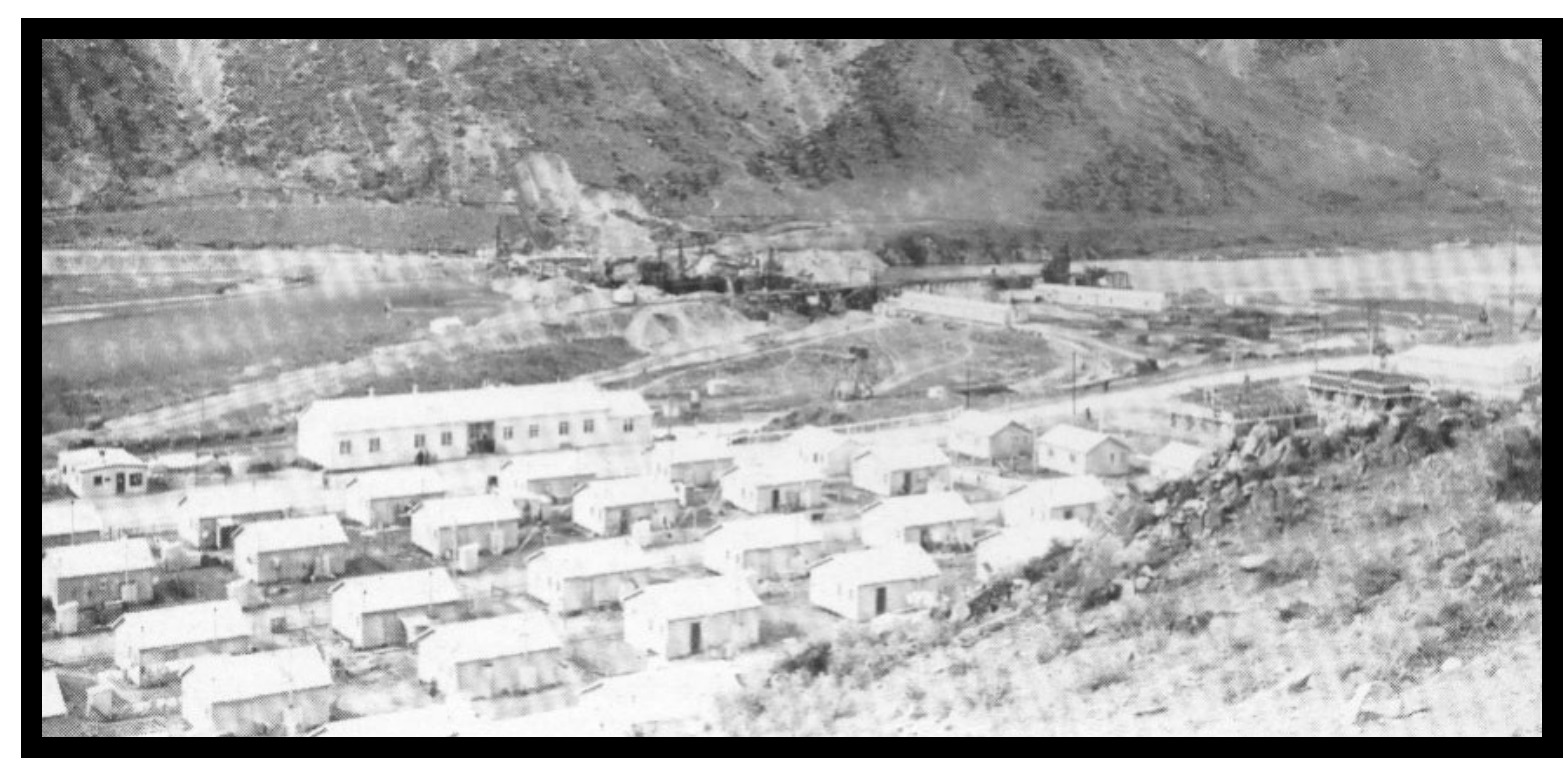

Figure 19: Huts in Deep Cove camp, 1MTT

When accommodation aboard the Wanganella ran out, a staff hostel was built on shore (completed in September 1967) and huts were provided for workers. The staff hostel was a two storey, timber framed building with corrugated iron siding and roofing and had 64 rooms.

103 huts for workers were prefabricated off site, shipped in and placed on a cleared site in Deep Cove, along with two ablution blocks. The huts were $2.4 \times 3.6 \mathrm{~m}$ and each hut had a chest of drawers, a writing table, infra-red heating, an electric light and a power point (the same as those at West Arm). Two ablution blocks were also placed on the site. The huts were timber framed, with ship lapped siding and corrugated iron roofing (see fig 19) (33. $^{83}$.

In October 1965 the $20 \mathrm{~km}$ Wilmot Pass Road was completed, connecting West Arm and Deep Cove (the construction of the road was a major undertaking in itself, involving excavation through swamps and solid rock of over 1,000,000 cubic yards). Once the road was completed, the workers based in Deep Cove could leave their accommodations a lot more easily, travelling over Lake Manapouri from West Arm on the regular ferry instead of travelling by ship through Doubtful Sound and along the coast to Invercargill.

\footnotetext{
${ }^{83}$ Stolz, p 27
} 
When the project was completed, all of the buildings except the staff hostel were removed. The staff hostel was gifted to the Department of Conservation and remains to this day as an education camp for schools from throughout Southland and Otago. 


\section{Manapouri}

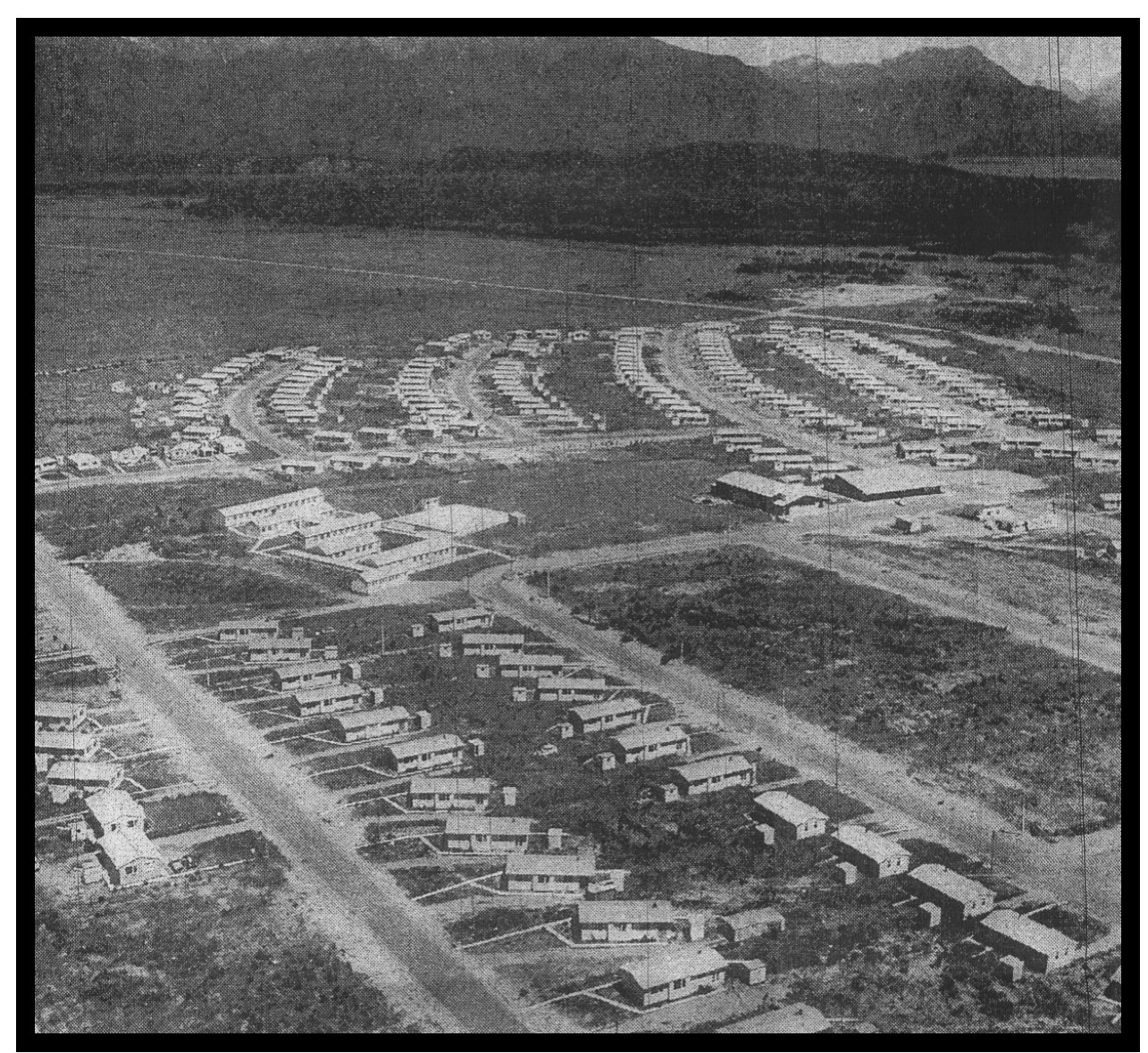

Figure 20: Manapouri construction village

To house the extra workers required for construction of the powerhouse (the tunnel had started two years previously), the camp at West Arm was enlarged and a temporary village for the married men and their families was built near the township of Manapouri (see fig 20). This site was convenient as it was connected by road to Te Anau. It had originally been proposed for West Arm but a decision was made to locate it on the mainland in order to attract more workers. ${ }^{84}$

The houses were brought from Invercargill, Dunedin and Gore MoWD sites and the village had a supermarket, a post office, a garage and both a primary and a secondary school ${ }^{85}$.

\footnotetext{
${ }^{84}$ Taylor, Manapouri, p 27

${ }^{85}$ Howard, Power from Fiordland, p 47
} 
There were eventually 249 houses placed in the village and workers were taken up the lake to West Arm each day by Fiordland Travel launches. Many of the occupants were Wilkins and Davies Construction staff but there were occupants who worked for the MoWD and the NZED also living there. The social structure was not as strict as previously seen in other MoWD camps as the staff (who far outweighed the workers in numbers) were from the joint venture, not the MoWD and thus did not have a culture of social stratification from the camps instilled in them.

The whole village, including the schools and shops, were transportable and after completion of the project the entire village was removed and the land was returned to the Lands and Survey Department. 


\section{0s}

While the architectural world began further experimenting with new materials, manufacturing methods and disaster relief efforts in terms of transportable mass produced housing, NZ was a few steps behind. Twizel was designed and built in the tradition of hydro towns in the region, rather than reflecting recent international innovations or the methods utilised at $1 \mathrm{MTT}$.

Twizel was designed much like an American trailer park in the late 1960s - the houses were rectangular and laid out on small sections with larger public areas, staggered to add privacy and on gently snaking streets, as at Otematata. However, the community that was to populate Twizel (the vast majority of which came from Otematata) felt that it could demand better facilities and housing from the MoWD than that provided previously and refused to move to Twizel unless these demands were $\mathrm{met}^{86}$.

Once Twizel was built, many of the occupants felt that their town was the pinnacle of the hydro towns and again a successful petition was made to retain some of it. This time however, the residents successfully petitioned to save the vast majority of the town. The occupants had learnt from Otematata that the houses were valuable and worth the upkeep as they may be able to purchase them at the end of the project at a very good price. As a result, Twizel today retains much of its township and housing from the project years.

In Australia at the time, portable housing was being seen as an answer to the problems of a vast continent with many remote regions. While there were only a few companies supplying transportable housing and only a few clients (although these clients often made very large orders as most were government agencies or large construction firms), the industry was strong. With the popularisation of transportable housing in America in the 1960s, many new companies were opening up in Australia to provide to the smaller clients and were soon having difficulty keeping the prices low for clients who often required a 'one off' building. The industry in Australia lost its popularity again as prices increased dramatically in response to the 'one off' clients.

${ }^{86}$ Sheridan, pp 91-2 
In 1977 the term "decorated shed ${ }^{87 "}$ was first coined to describe a building which is very honest to its function and quite bare, yet ornamentation is applied completely without relationship to structure. It is interesting to note that this term was coined at the same time as the number of houses in Twizel peaked as this would seem to be the perfect description of what these houses were beginning the transformation into (as had happened and was continuing to happen at Otematata) as the residents sought to express their individuality.

${ }^{87}$ Venturi, p85 


\section{Twizel 1969-84}

"It is hard to believe that in 1968 Twizel was non-existent. No houses, no streets - just a bare stretch of land holding the promise of a possible future. No-one could envisage then what we see today. There were no plans for permanence; most people accepted that Twizel would be a temporary township." ${ }^{88}$

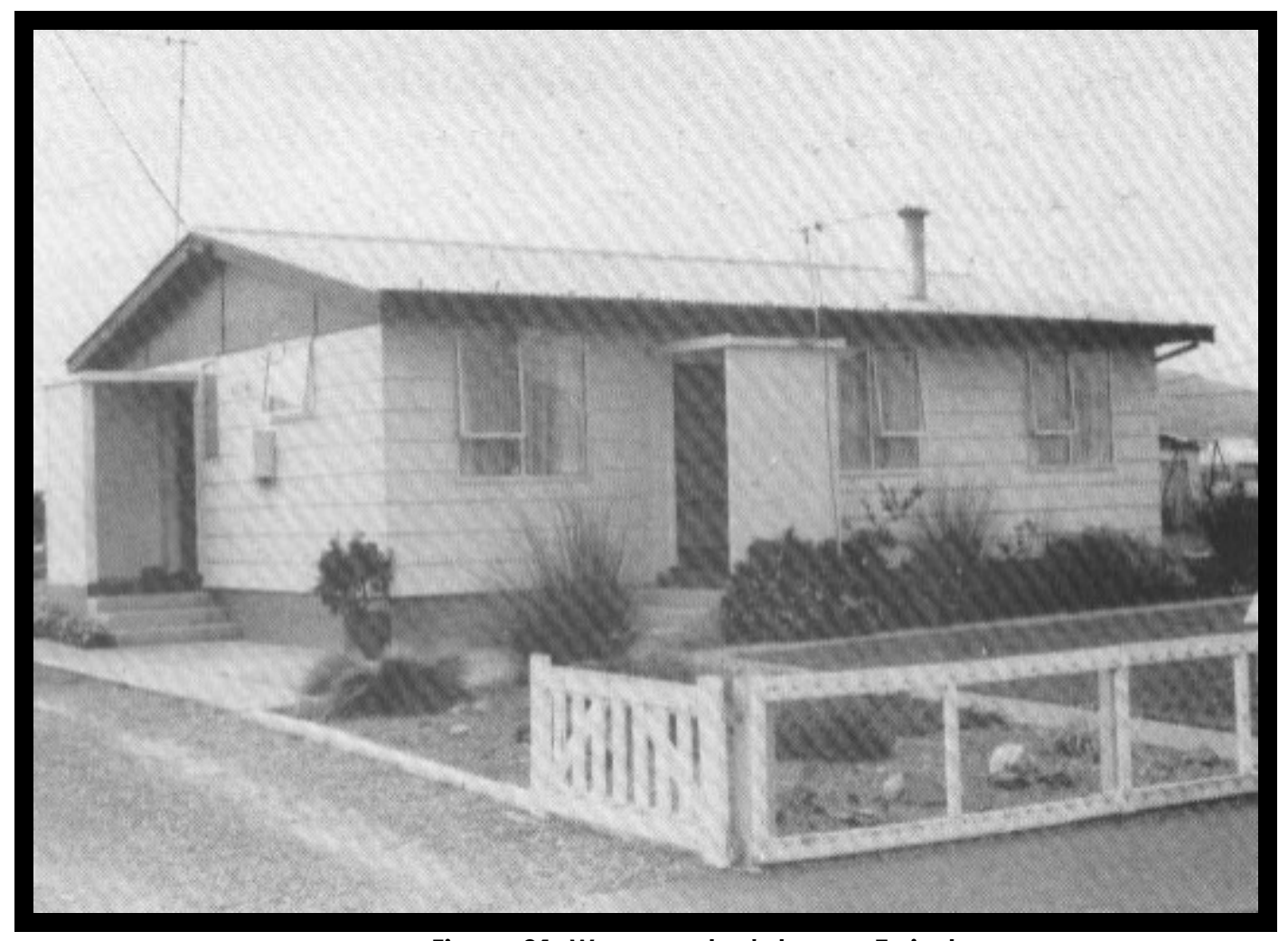

Figure 21: Wage worker's house, Twizel

Twizel was the next stop after Otematata for the growing population of hydro workers in the region. However, from the beginning it was obvious that the houses may not be able to follow this time. Many had been used continuously since Roxburgh or Hawea and had withstood the rigours of updating at Otematata. Another update and another long truck journey was going to test the structural limits of the houses a step too far. Not only this, but the even harsher climate of the MacKenzie Country was going to require further modifications to the design.

Thus it was decided that new housing would be constructed for Twizel, with a few of the houses which had been built specifically for Otematata to be retained and

${ }^{88}$ Sheridan, p 101 
modified. These new houses were designed by Superintendent Charlie Speak and Overseer Albie Green of the MoWD.

As soon as news came through to Otematata that new houses were to be provided, the Otematata subsection of the Public Service Association set up four subcommittees to investigate and prepare recommendations regarding the housing and planning of Twizel to be put to the MoWD. Among the recommendations was a minimum house size of $830 \mathrm{sq} \mathrm{ft}$ for all permanent staff (previously moving house between 520 and $820 \mathrm{sq} f t$ had required new rugs, new curtains, new furniture, etc), insulation for the housing (in comparison to Otematata), a porch to be added to the houses upon request, a stainless steel basin to be provided in the laundry and a garage and wet-back stove be provided in each house. This meant that the houses from Otematata would need to be substantially altered and "concern was felt that economic restrictions would tempt the department to skimp or waive altogether"89 the request for better insulation and heating than that provided previously, which were felt to be imperative by the workers and their families.

By mid-1969, the subcommittees had furthered these recommendations to a minimum size of $860 \mathrm{sq} \mathrm{ft}$ for permanent staff, with a shower and separate indoor toilet, that an adequate number of four and five bedroom houses be constructed, that when a house extension was required a room be added rather than a hut and that all electricity be charged at the same rate as electricity supplied at the NZ Electricity Department permanent villages (with houses now larger and with a more severe climate than at Otematata, the price of electricity became a major concern. At Otematata, the cost of running electric heating had been a shock to many. $)^{90}$ Although an upgrade of accommodation for the singlemen was discussed, it was rejected by the workers' organisations who were satisfied with remaining with the existing system - huts for wage workers and hostels for staff.

By June 1969, there were still only seven houses, 32 huts, one cookhouse and the large vehicle garages in position at Twizel. The move to Twizel was due to commence in March 1970, but the subcommittees put a ban on all movement until

\footnotetext{
${ }^{89}$ Sheridan, p 91

${ }^{90}$ ibid, p 92
} 
their recommendations were met by the MoWD. By late March the Ministry agreed to meet their "recommendations", with only a few changes. Wet-backs were not to be installed, however the staff would get 60 gallon water heaters and solid fuel heaters in the form of coal burning stoves (both of which drastically affected transportability of the houses, suggesting the MoWD was already planning for possible retention, yet still publicly calling the town 'temporary') and a site allowance to reimburse staff for extra fuel and electricity rather than provide cheap electricity. This placated the subcommittees and the move to Twizel was started ${ }^{91}$.

Construction had begun on the huts in the carpentry workshop at Otematata in 1968 , as work began to come to completion on the Aviemore dam and the workshop now upgraded into full production mode on the houses.

The workshop at Otematata operated on a production line which saw a new house of $750 \mathrm{sq} \mathrm{ft}$ turned out in a day. Although 250 of these houses were built at Otematata, this was not going to be enough and so De Geest Brothers Construction Ltd of Oamaru was contracted to begin production of the prefabricated modules at their factory. De Geest were eventually to construct 467 houses for Twizel at Oamaru and transport them to site by truck through the Waitaki valley.

The housing was predecorated, papered and painted, with kitchens, laundries and bathrooms decorated in warm tones. Each house had also been allocated a variety of trees, shrubs and grass seed for the section (see fig 22) and garages were provided at the back of the section.

The huts were $4 \mathrm{~m} \times 2.6 \mathrm{~m}$ and built of treated pine. They were, once again, a single room, but with a built-on porch. They contained storage space for clothing, a bed, a table, a chair and a small "rangette" for heating and were predecorated.

A hostel from Hawea was transported to Twizel, followed shortly after by the Benmore hostel from Otematata. These were supplemented with two new hostels built on site which provided accommodation for a further 60 staff and kitchen, dining room and lounge facilities

${ }^{91}$ Ibid, pp 92-93 
As in previous hydro towns, "MoWD staff housing was segregated from that of wage-workers, and singlemen were required to live in the segregated camps and hostels, rather than flat in houses ${ }^{92 "}$

In 1966 Higgins Earthmoving Company arrived and set up a temporary camp beside the Twizel River. They had previously been awarded contracts at the Benmore and Aviemore projects and performed intermittent roading work in the Twizel area while investigations were proceeding. It wasn't until 1969 that they began winning substantial contracts on the jobs in the Upper Waitaki and they were the last contractors to be still working on site in the early 1980s.

The Higgins camp was known as "Higginsville" and was completely selfcontained (as opposed to other contractors who separated their work yards and their living quarters) and positioned on the other side of the river to Twizel. The entire camp was portable, with mobile homes provided as staff quarters for the single men and for Higgins family members. The offices, singlemens' ablution block, cookhouse, common room, garages and workshops were designed to be collapsed and reassembled. The men in the Higgins' employ who were accompanied by families rented houses in Twizel from the MoWD.

At its peak, in mid-1977, Twizel's population was nearly 6000 , accommodated in 1300 houses, 800 singlemens' huts and four hostels.

The town centre was well planned, with the main bus terminal close to the shopping centre (see fig 22). The residents felt that this town was the peak of the single purpose towns and that their involvement had ensured that the accommodation provided and the planning of the town left little to be desired. Many of the workers were nearing retirement by the late 1970s and expressed interest in buying the houses that they were living in once the project finished. Although Twizel was not intended to be a permanent town, many of its residents began to petition to keep parts of it. Thus, in February 1984, the Minister of Works handed over Twizel to the MacKenzie District Council, along with 325 houses, 14 shops, the community centre and various other amenities.

${ }^{92}$ Taylor et al, Resource Community Formation and Change: A Case Study of Twizel, p 33 
A number of the houses had been purchased by their occupants (spurred on, no doubt, by the massive resale values that those who had purchased at Otematata were achieving - many having purchased houses for $\$ 850$, were selling them for $\$ 20,000$ a decade on). This was also a reflection of the great confidence that the workers had in their township.

Many of the singlemens' huts (and some of the houses) were sold at auction and moved to privately owned sites around the region. A high proportion of the singlemens' huts can now be found as accommodation on orchards and farms. Some of the houses were given as charitable donations to various organisations around the region (although many houses are now almost unrecognisable as a result of the changes made to them). 


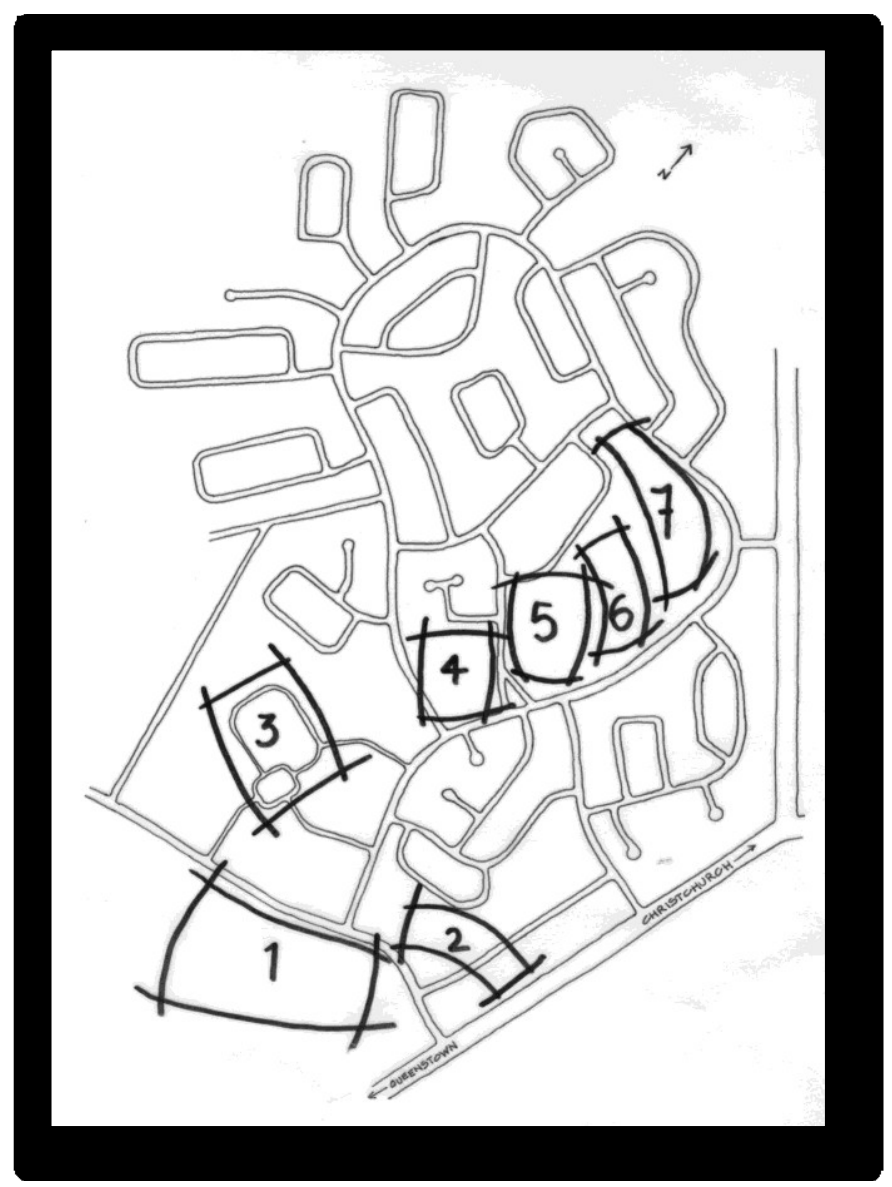

Figure 22: Twizel town plan, 1977

1.Industrial Area

2.Tourist Facilities

3.Singlemens' Camp and Canteen

4.Staff Hostel

5.Shops and Community Services

6.Schools and Sports Facilities

7.Sports Fields

Note: the only changes to the town plan since 1977 are that the industrial area has diminished and the tourist facilities have expanded

As at Otematata, there is one feature of prefabricated modular housing (other than its similarity) that is obvious - the orientation of the houses gives away the placement of the buildings by trucks. This is a trait which remains the same whether it is in hydro villages in New Zealand or trailer parks in the United States of America - orientation of rectangular buildings dependent on a truck being able to back into the site is a dead giveaway. Unfortunately, this feature also often reduces the possibility of private backyards (see fig 23) as neighbours' houses are slanted towards each other' backyards (although positioning of garages and some fencing was used to reasonable effect to counter this visual intrusion at Twizel). 


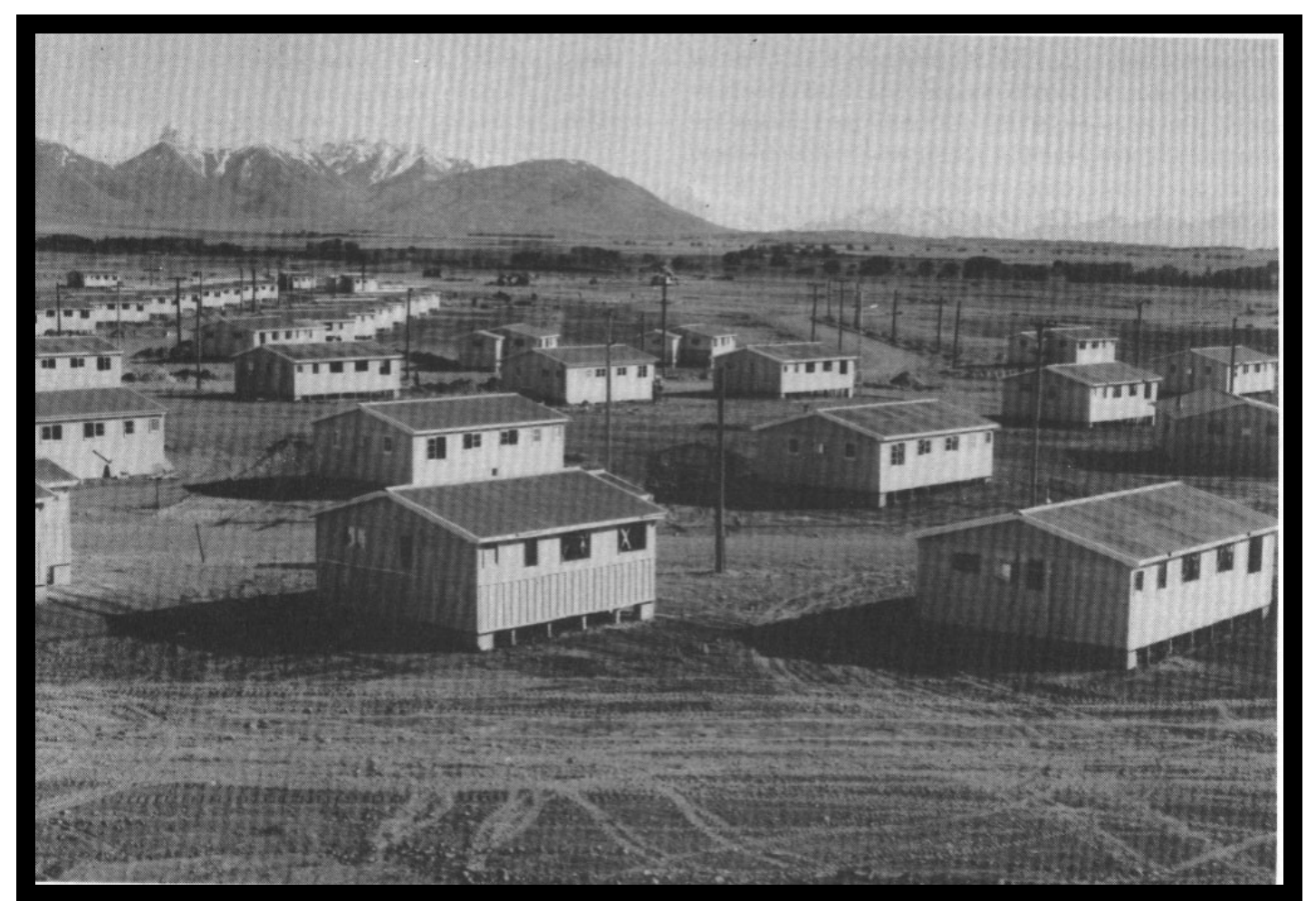

Figure 23: Houses in place at Twizel 


\section{0s}

It was during the 1980s that the proliferation of trailer parks led directly to a popular rejection of prefabrication in America. As a result of trailer parks taking over from the inner city slums, prefabricated transportable buildings became an unfashionable solution, conjuring up images of cold and draughty temporary classrooms and overflowing trailer parks with their associated social problems.

Mobile homes had started being manufactured in larger sizes, with many different fitout options. Financing was readily available (as repossession of a mobile home was quite simple) including to higher risk applicants who would normally be rejected for housing finance. The downside of this was that financing was at a higher rate of interest than other loans and the personal property taxes applied in some areas often meant that the cost of upkeep for a mobile home was higher than for an apartment. A mobile home was no longer seen as a step up towards buying a house as the advertising of the 1960s and 1970s suggested, but a permanent housing solution for the lower socio-economic groups, the upkeep of which would ensure that they could not save enough money to leave.

It also became obvious that the vast majority of these "mobile" homes were never moved once they had been put in their first location. Often this led to additions such as porches and external roofs being added, adding some financial and aesthetic value to them but in the long term it became obvious that these trailers did not last forever and some were left to deteriorate while still being rented out. This led to a proliferation of trailer park slums, housing the very poorest of society.

Undoubtedly these slums have been the greatest detractor for the prefabricated transportable housing market. The mobile home market itself has tried various campaigns to reduce this image, including undergoing yet another name change (originally known as "trailers" they had been remarketed as "mobile homes" and were now to be known as "manufactured houses"). Another attempt at raising their profile was made by manufacturing larger and more expensive models aimed at the truly mobile retired portion of the population. All that this has changed is that there are now huge variations in the quality of trailer parks in various regions. It has not 
reduced the slum trailer parks in the least desirable areas on the outskirts of large cities but has led to more exclusive trailer parks available in more desirable locations in areas popular with the elderly, but not usually easily visible to the general population. As such, this did very little to change the image of mobile homes in America.

In the meantime, the American image of trailer park slums was becoming a part of popular culture throughout the industrialised world and, despite efforts in NZ to introduce mobile homes as a viable option for low cost housing and modifications to land ownership, financing and design from the American model being suggested, it was never taken up. ${ }^{93}$

In Japan, the writings and works of Toyo Ito were revitalising architectural and artistic interest in the temporary nature of traditional Japanese architecture. Ito stated "architecture is an extremely transient existence like a piece of film wrapping a human body. It does not have a substance, nor implies weight. Designing an architecture is an act of generating vortexes in the currents of air, wind, light and sound. It is not constructing a dam against flow, nor resigning oneself to the current ${ }^{94 "}$. However, Ito's thinking was not internationally popularised until after the 1995 Great Hanshin Earthquake.

In NZ, the 1980s was the first decade that the government was not actively facilitating access to home ownership or focusing on the provision of social housing as part of its platform. Housing prices began to rise as a result.

Also, in 1987, the NZED was corporatised and became the ECNZ. By 2000 the ECNZ was broken into three state-owned power generation corporations. Meridian Energy took control of the projects looked in this thesis (although there is talk of handing 2MTT to Genesis in 2011).

The retention of parts of Otematata and Twizel was a prompt to the MoWD to upgrade the next hydro town to being a permanent satellite suburb of an existing town. This also worked to reduce popular concerns about another transportable

\footnotetext{
${ }^{93}$ For example "it is not suggested that the mobile home is the answer to all our housing problems far from it - but there is an apparently unsatisfied need in the low-cost-housing area which might well be met by such a product. This need stands as a challenge to the private business sector" Conroy, B, "Mobile Homes - A Viable Alternative?" p 20

${ }^{94}$ Toyo Ito, "Vortex and Current - an Architecture of Phenomenalism" in Japan architect 06/1988
} 
township in the region which could potentially turn into an American-style slum (even though there had been no previous examples of this happening in the region).

Between the projects at Waitaki and Cromwell, the houses had become comfortable and permanent and the singlemens' accommodation had become desirable as lower end tourist accommodation.

Then, on April 1 1988, the MoWD was abolished and many of its ongoing projects were tendered out to private enterprises. At the same time the Works and Development Services Corporation (a government owned trading enterprise) was established to take over the majority of the MoWD's commercial operations.

Environmental consciousness was also growing in popularity during the 1980s and this put new pressures on temporary housing in sensitive environments to 'touch the earth lightly' and 'leave only footprints'. A whole new world of issues were introduced to the industry, such as raising the buildings off the ground, finding ways to make their products able to be transported back to their home country when their lifespan is complete (so as not to leave rubbish in areas unable to reuse, recycle or dispose of them) and heightened interest in using recyclable materials. 


\section{Cromwell 1977-90}

"Due to a combination of the fact that the construction period will be unusually long....the development of the project within a well established existing town and the likely emergence of a Cromwell which will be significantly larger that that which exists at present, it is considered an essential prerequisite that all development be carried out to permanent standards. Development standards should be in line with those that are acceptable both nationally and locally. It is particularly important that no houses or project or private buildings be established which, by their appearance

and/or standards of construction, would tend to give the indication of being temporary rather than permanent ${ }^{95}$

The planning of the hydro village at Cromwell was vastly different to any that had previously occurred for two reasons - the hydro village was to be located within the boundaries of an existing town and the local Council was to get involved with the planning.

This new approach was partially because the dam was going to create a lake which would inundate part of the existing shopping area and highway. This meant that a great deal of new town planning was going to have to occur in Cromwell, a new shopping mall would need to be built and the traffic flow would require major alteration.

As a result of these considerations and with reflection that the last two hydro villages had successfully petitioned to be at least partially retained as towns combined with the expectation that this project may last around 25 years, it was decided that the hydro village should be incorporated with the existing town. The town would require upgraded facilities to meet increased need including schools, recreational and leisure facilities and housing. The increased workforce population for the MoWD project would also bring with it an associated increase in population of families and service providers.

In anticipation of this and following the recommendations of the Town and Country Planning Act (1953), the Vincent County Council and the Cromwell Borough Council created a combined planning council in order to create a Cromwell District

\footnotetext{
95 Joint Planning Committee, p5
} 
Scheme which would be administered by the Cromwell Council. The Housing Corporation was also involved in the planning of the housing development.

The draft District Scheme was adjusted numerous times as construction plans were altered by the MoWD, but, after a slow start, in September 1977 \$1.5million was made available by the government for construction of 49 more houses. In October, tenders were called for a further 120 houses. De Geest successfully tendered for all five of the contracts encompassing stage one of the housing programme, continuing their longstanding relationship with MoWD project accommodation in the region.

Also in 1977 the Bannockburn Road camp was established, with Bennett Dawson and Ross building three hostels, each with eight bedrooms. Eventually 200 huts would provide the balance of the singlemens' accommodation at Bannockburn Road, outside of Cromwell.

By 1979, the adjustments and associated controversy regarding the District Scheme were creating a financial problem for Cromwell Council. Although the MoWD was paying the planning costs, they were not covering the additional costs and these expenses were beyond the rating returns received by the Council. Eventually this situation snowballed into the Council threatening to cut all services to one of the MoWD personnel housing development areas and refusing permission for settlement of it until Treasury paid the outstanding amount.

The year 1979 also saw the beginning of earthworks for the dam by the MoWD, at a time when the Ministry was short 165 accommodation units for married workers and 17 for single workers which were supplied by existing rental accommodation in Alexandra and Cromwell. The Ministry had to provide allowances for rent for their workers and this further increased the rental rates in the area, which had doubled between 1974 and 1979.

Shortly after this there was a change of government and with it came a change of plan for the Clyde Dam. The new plan would result in fewer workers required on site and this, in turn, would affect the housing provided and the layout of the new developments. This decision was made as a result of revised projected power needs which were much lower than previously estimated. While the MoWD did not see it 
necessary to reduce staff levels to meet the reduced size of the project, they did finally agree to reduction of the number of houses to be constructed - down from 900 by the mid-1980s to 650 . While the eventual number of houses required was of great concern, in reality there were only 176 houses complete and 198 more under construction at this stage (in 1979).

There was concern in the community that the impact of the additional housing requirements on Cromwell (and, to a lesser extent, Alexandra) was going to raise housing prices to an extent that the locals would be unable to afford to live in their own town and some would end up living in temporary and below standard housing. In reality, the housing pressures created in Cromwell led to great increases in rental rates for local owners, huge increases in resale values for local homes and a general increase in wealth for the local people. ${ }^{96}$ Also, while the new housing areas were isolated from the existing township, an integration of the workers into the community was forced by the rental of existing housing stock within the township.

The planners failed to anticipate the Government's call for tenders for construction of the Clyde Dam. The Government had decided that the role of the MoWD would have to be justified in response to the many calls from contractors to be able to compete but, by opening up the construction tendering process to contractors, the needs of the workforce were thrown into doubt. It was recognised that contractors would bring far more singlemen than families (requiring less housing than the MoWD projects traditionally had and more singlemens' accommodation) and that the contractor may in fact choose another location altogether to house the workforce.

Despite this, tenders were called to begin another residential subdivision in March 1981 and by November it had been agreed to transport houses from Twizel as temporary accommodation for the contractors' staff.

Tenders for construction of the dam closed in January 1982. The work was awarded to a consortium of Ed Zublin (from Germany) and Williamson Construction (from Christchurch, who had only $2.5 \%$ of the partnership, particularly advice on labour relations and wage rates). The powerhouse and right abutment (as well as

${ }^{96}$ The Local Impact of the Upper Clutha Scheme, p 6 
the foundation work and river diversion already completed) were to be built by MoWD and the contract for the turbines and generators was awarded to Hitachi (of Japan). As a result, this was the first hydro settlement since Roxburgh that was not going to have a vast majority of occupants employed by MoWD.

Several other Councils realised that they could potentially gain subdividable land with services by offering bare land to the contractor for siting of staff accommodation (when the temporary accommodation was removed the Council would be left with large subdivisions which would already have services to them for very little cost to themselves). This was attractive to Alexandra and to Wanaka and both Councils began to investigate ways of making themselves more attractive to the contractor. However, the contractors decided to settle the majority of their staff in Cromwell.

The expansion of Cromwell was accelerated once the contracts were awarded. By 1984511 houses were in place (including 88 temporary transportables from Twizel, 86 lightly clad houses with the potential for removal and 337 masonry clad houses ${ }^{97}$ ) and by 1986 the population of Cromwell was 3,500 (in comparison to a population of 1,200 in 1976). The relocatable houses from Twizel were renovated and located in an area which would be returned to pasture after completion of the project (when the houses were mainly auctioned off to be relocated), separated by quite a distance from the permanent housing.

The majority of houses have three bedrooms, with the vast minority having either two, four or five bedrooms. A standard three bedroom house is 1140sq ft (106sq m) and sits on a site of around $690 \mathrm{sq} \mathrm{m}$, with a garage, fencing and individual title. In comparison, the Twizel transportables (also three bedroom) had a floor area of 730 sq $\mathrm{ft}$ (68 sq $\mathrm{m}$ ) and did not have individual title or fencing ${ }^{98}$.

It had been decided very early on in the project that the majority of housing should be of a permanent nature so that it could be retained after the completion of the dam and sold as holiday or permanent housing with employees having first option on purchasing the homes that they were living in. This required a step up in the quality of the housing. However, this was not reflected evenly throughout the

\footnotetext{
${ }^{97}$ MoWD, "Description of Houses", National Archives AANU 9087480 L1096 pp 8-9

${ }^{98}$ MoWD, "Description of Houses", National Archives AANU 9087480 L1096 p 9
} 
population. The Germans (working for Zublins) had a higher standard of living within these houses, including having everything supplied for them. Meanwhile the locals (mainly working for MoWD) were relegated to the lower quality housing, particularly that transported from Twizel, and had to provide all their own bedding, kitchen utensils, and the like.

Singlemens' accommodation (Bannockburn Road camp, see fig 24) was once again removed by quite a distance from the married accommodation and the singlemens' accommodation was divided by the shifts in which the occupants worked.

New types of hostels were introduced for the Zublins staff and other types of singlemens' accommodation was introduced, including connection of huts by corridors to communal living, cooking and laundry facilities. This was a great improvement in comfort for the workers as they were no longer required to leave the shelter of the buildings between their shifts if the weather was miserable. This was again constructed by De Geest Brothers of Oamaru and trucked to site. The Dam was completed in 1990, by which time the population had stabilised at 3,000 . 


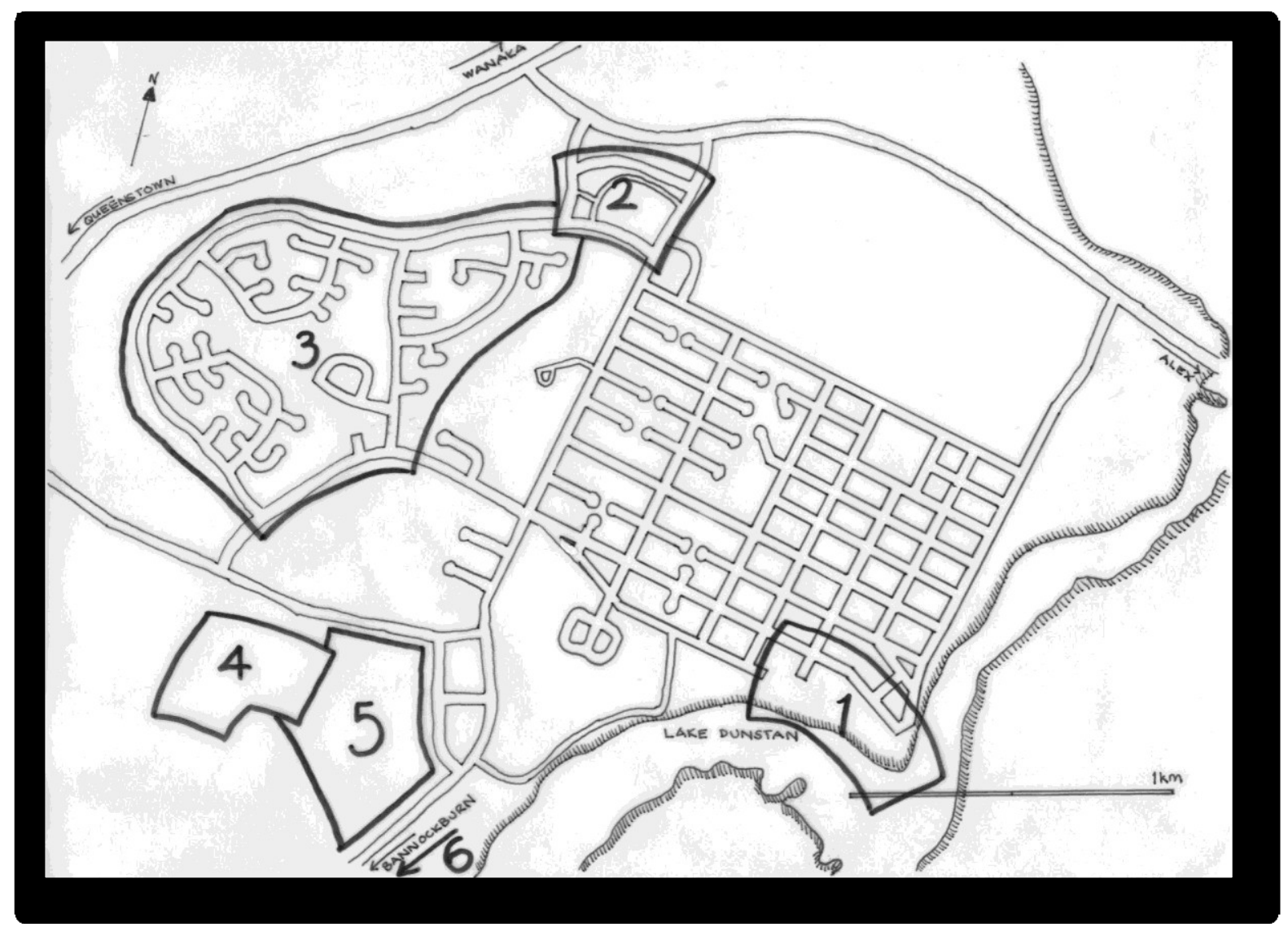

Figure 24: Cromwell town plan

1 - old shopping area

2 - new shopping area

3 - new housing area and twizel transportable houses

4 - project office and zublins hostels

5 - project industrial area

6 - singlemens' huts 


\section{0s}

In the late 1980s and early 1990s, transportable housing investigations increased again as international aid became a popular cause in the First World. As a result of this, progressive thinking in terms of transportable architectural solutions (particularly that coming out of America) were predominantly in the realm of either military or emergency response.

The greatest exception to this in recent years has been in temporary classrooms. In the late 1990s, the New York School Construction Authority responded to a sudden surge in the school population by employing FTL Happold to design a new form of portable classroom to replace the existing double-width mobile home units ${ }^{99}$. The major problems with the mobile home units were that they were expensive and that they had to be moved into place by crane. The largest amount of criticism came from the fact that the learning environment provided in the existing mobile classrooms was inadequate.

FTL devised a portable classroom based on a modified truck trailer and deployed from a dedicated trailer truck yard. The end product is a $8.5 \times 7.6$ metre classroom with an expected set up time of around 24 hours. The classrooms are entirely independent of the grid (including toilets, water and fuel storage) to enable them to be located anywhere that their transportation method allows.

FTL have employed a weatherproof luminous fabric and external graphics which ensure that the classrooms are identifiable and attractive to their users, unlike their predecessors. These classrooms are insulated, well lit, secure and mobile, as well as cheaper, than their predecessors and are used in over 100 schools in a 25 kilometre radius of New York.

Also, the architectural academic programmes in the First World seem to be providing many projects involving transportable architecture and prefabrication.

At the end of the $20^{\text {th }}$ century Britain again became Europe's leader in transportable housing solutions, mainly due to one man's efforts - Dr. Robert

\footnotetext{
${ }^{99}$ Kronenburg, Robert, "FTL Happold: Mobile Campus: New York City" in Toy, Maggie (ed), Architectural Design Profile 135: Ephemeral/Portable Architecture, London: Vol 68 No 9/10 September/October 1998. p 81
} 
Kronenburg, of the University of Liverpool's School of Architecture and Building Engineering, recognized a lack of precedent study in the portable architecture realm. Designers working on portable architecture seemed to start from a clean slate each time they designed a portable building, rather than learn from others' experiments and this led to Kronenburg creating the Portable Buildings Research Unit (as well as curating several exhibitions and publishing several books). The PRBU organised the first Transportable Environments conference in 1997, which was the first international conference dedicated to transportable and demountable buildings. Since then there have been 3 more of these conferences held.

In America, the work of Jennifer Siegal in popularising transportable architecture in the academic realm also began to receive greater attention.

In Japan, the work of Toyo Ito was well publicised when Shigeru Ban, prescribing to Ito's theories, produced paper houses as temporary accommodation (and a paper church) in response to the Great Hanshin Earthquake of 1995. These examples of both environmental consciousness and the ability for architecture to be light have opened up a whole new area of transportable housing, focusing on its transience.

Meanwhile, in NZ, the first environmentally sensitive hydro camp was built at West Arm (a heritage area), the first camp to be required to be built under the NZ Building Code (NZBC), requiring the same standards as permanent accommodation.

The years 1991-96 are the only ones in the second half of the $20^{\text {th }}$ century in which there was not a hydro construction camp occupied in the region studied. 


\section{Second Manapouri Tailrace Tunnel \\ 1997-2002}

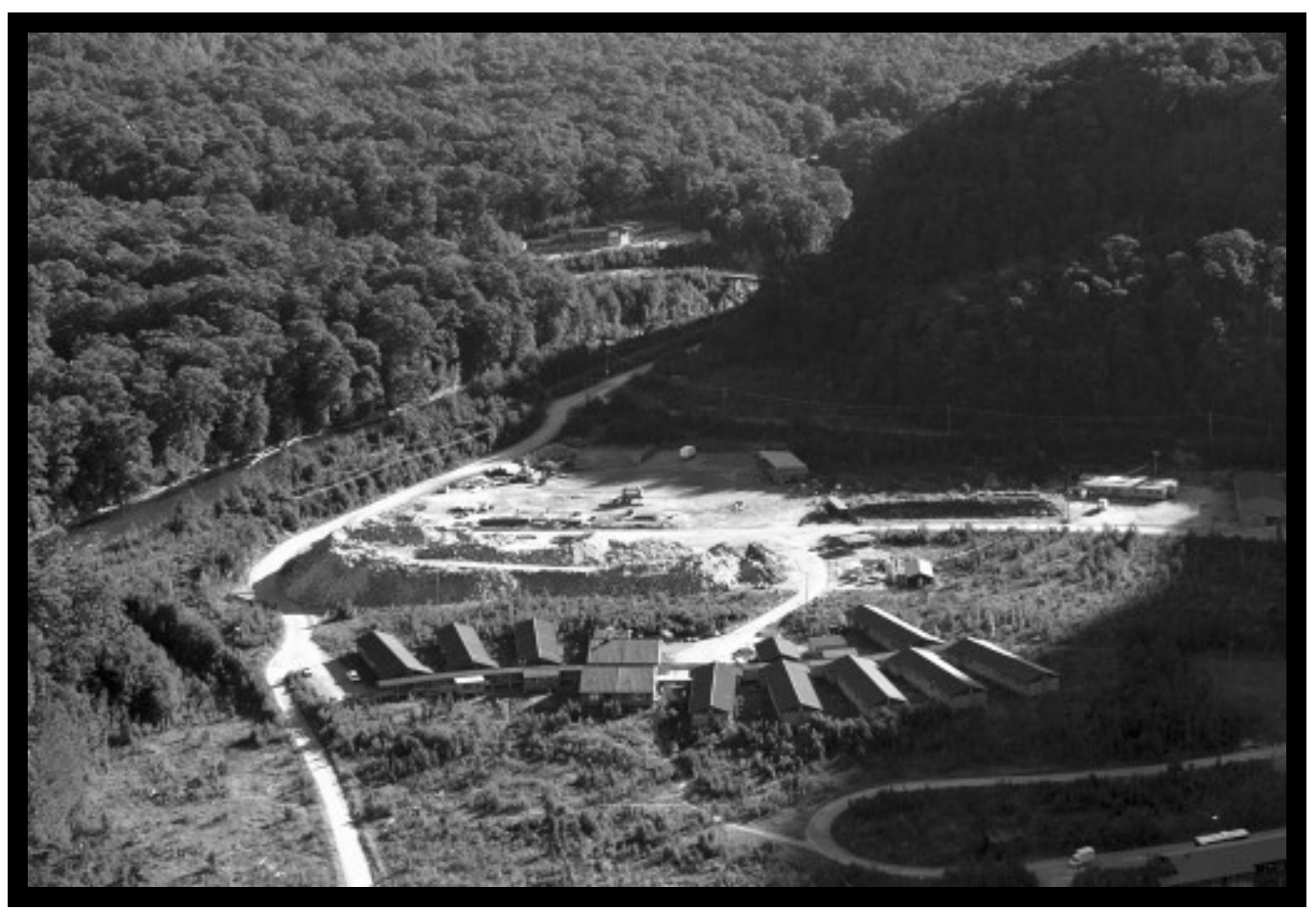

Figure 25: 2MTT camp, 1999

The First Manapouri Tailrace Tunnel and power station (1MTT) is seen by many as the birthplace of NZ's mass environmental consciousness as a result of the massive "Save Manapouri" campaign that successfully stopped the planned raising of the lake level in the 1960s.

Prior to letting the contract for the Second Manapouri Tailrace Tunnel (2MTT), ECNZ met with local authorities, the Department of Conservation, Ngai Tahu, the Southland Conservation Board, the Guardians of Lakes Manapouri, Manowai and Te Anau, the Deep Cove Education Trust and Fish and Game Council representatives to agree on the required environmental outcomes for the project.

The private enterprise joint venture excavating the second tunnel (Fletcher, Dillingham, Ilbau (FDI)) was also understandably keen to avoid such mass campaigning as $1 \mathrm{MTT}$ faced and allocated approximately $5 \%$ of the overall budget to long term environmental concerns (the short term aesthetic effects were met by 
the colours and designs of the workers accommodation and by maintaining vegetation screens).

The plans for regeneration of the site were implemented at the onset of construction by collecting excavated top soil and river flat medium and stockpiling it alongside rock spoil for later use. Seeds were also collected from many plant species around the site and sent to Te Anau for germination.

FDI needed to vastly enlarge what was left of the West Arm camp from the 1960s and employed Carson Group (Dunedin) to design the accommodation to meet both the visual and the physical environmental requirements. Accommodation was in a hostel format, with modules raised above the ground on concrete block foundations, prefabricated off site. The connection between the modules was via a walkway (also prefabricated off site) to reduce damage to the site. A recreation facility of a similar style, containing a pool room, a video room and a bar, was also brought in to West Arm and connected to the hostel via the same raised walkways.

Despite its location and intended lifespan, these buildings had to comply with the Building Act, requiring both smoke alarms and sprinklers.

Each bedroom contained a heater, a single bed, a desk (with four drawers), a chair, three power points, a low clothes hanging unit, a mirror, a light above the bed and a tv point. The door was lockable and the windows had insect proof ventilation strips along the bottom (there were also insect proof doors at every entrance point). The rooms were very warm and dry, with none of the condensation or insect problems associated with earlier buildings on site (see Appendix $\mathrm{H}$ for photos of these rooms).

The largest complaint about the buildings was the noise - not from other residents, but from the Keas, who adopted a habit of picking up small stones and dropping them on the corrugated metal roofs.

Ithough designed to accommodate 160 people, as staff numbers rose some rooms ended up having bunks put in, with each being used by a person on a different shift - ie: one night shift worker and one day shift worker sharing a room. Eventually, FDI added accommodations for another 20 people. 
When the accommodation was being designed, future use as school classrooms had been envisaged for the buildings. However, when the project was completed the Ministry of Education did not want the buildings, so the buildings were (mostly) put out to tender. Both Borland Lodge (a DOC education base at Lake Manawai) and the DOC education base at Deep Cove were located in hostels from 1MTT and DOC was gifted modules from the second stage to update these bases.

Eventually the remainder of the 40 modules were bought by Scobies (of Wyndham) who barged transportable cranes and trucks with lowerable decks to West Arm, lifted the modules off the concrete blocks which constituted their foundations, drove the trucks under the modules and lowered them onto the decks, removing the concrete blocks afterwards (see fig 26).

While these modules were popular on site, there was never a possibility that they might stay at West Arm and services were installed accordingly. Some service connections still in place from 1MTT were utilised and any additional needs were met by temporary installations. All temporary sewerage and power solutions have been removed from site.

The size of the workforce on this project was substantially smaller than that of any other NZ project looked at in this research. Modern technology meant that a smaller workforce was required, entertainment (in the form of tvs and radios) was available in individual rooms and the regular ferry service made it much easier to spend leave elsewhere. These factors combined with the lack of families to create less of a sense of community on this project than on many previous projects ${ }^{100}$. In 2001, the project was named as one of six global finalists in the environmental section of the Financial Times Global Energy Awards. The project was commended for its sensitivity to the natural environment and its positive impact on global warming.

250,000 seedlings were propagated from the seeds collected at the beginning of the project and planted in the top soil and river soil collected and placed on the rock spoil formed into natural landscaping. The seeds took three years to plant, from

${ }^{100}$ Meridian, "Technology and Teamwork”, p 11 
2000 to $2003^{101}$. Meridian Energy anticipated that there would be no visual scars left on the site by 2009 , but this has proven to be a premature estimation.

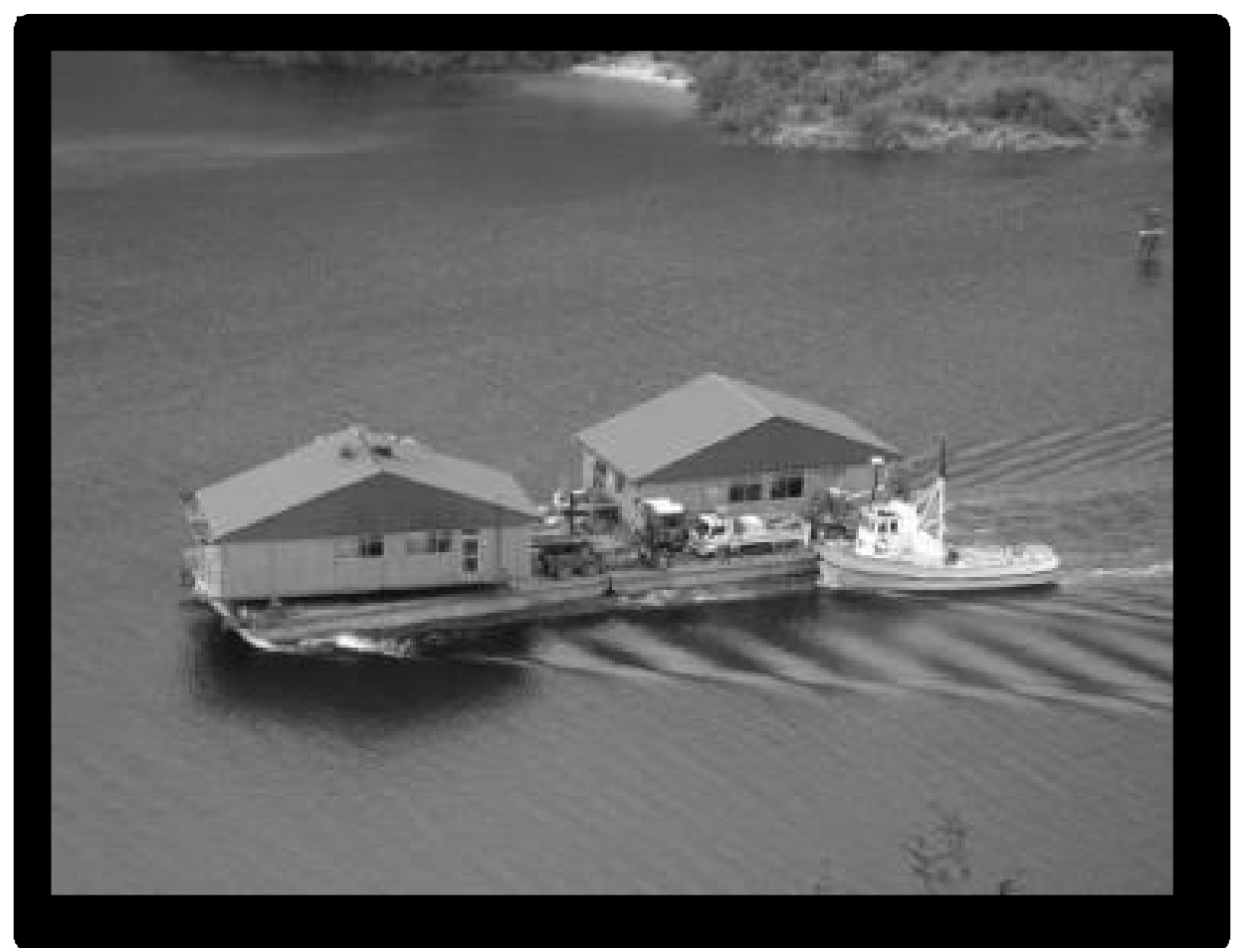

Figure 26: West Arm FDI staff hostel sections being barged out, 2002

${ }^{101}$ Meridian, "Manapouri”, p1 


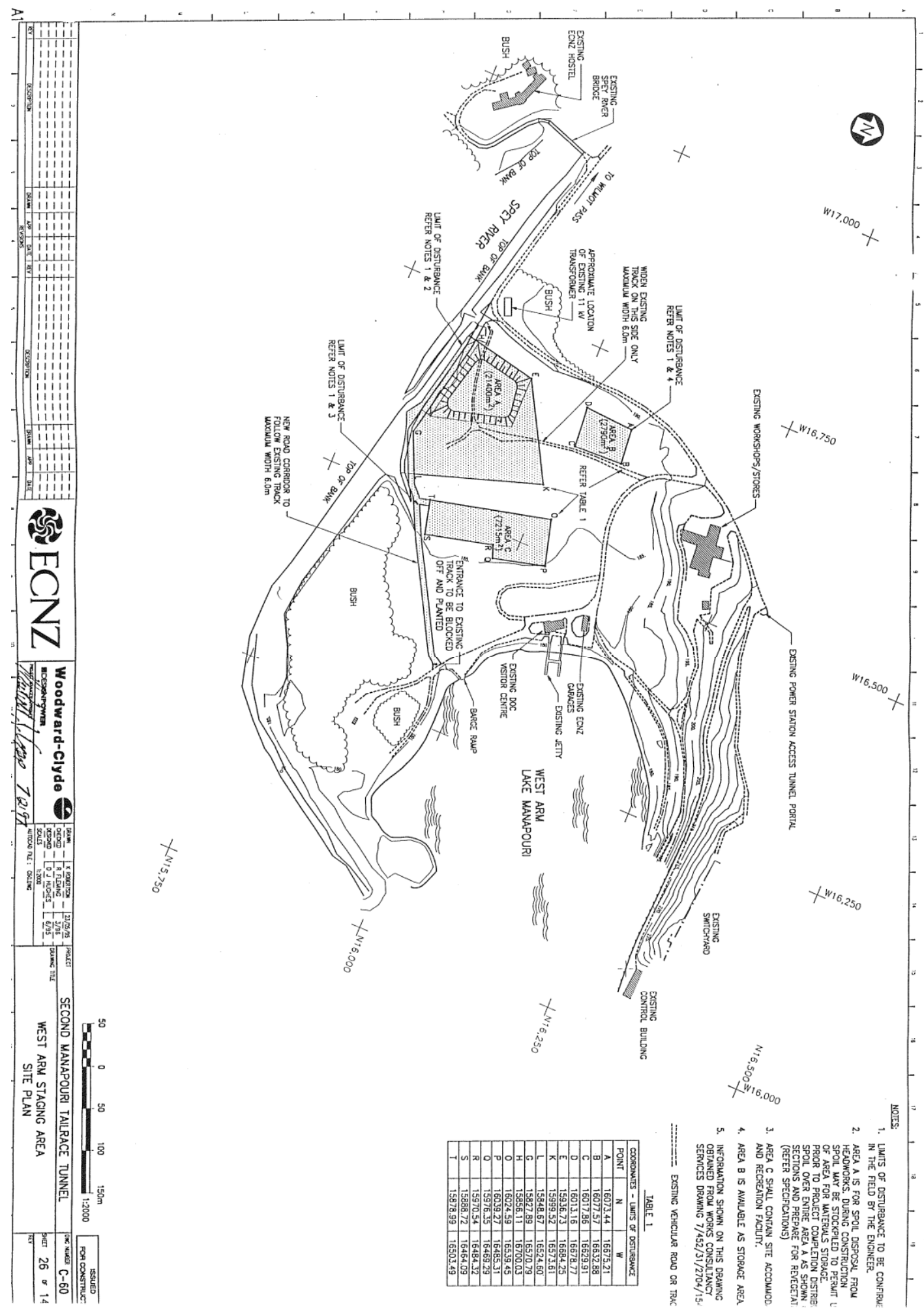

Figure 27: 2MTT camp layout, West Arm 


\section{0s}

So far the 2000s have already further defended the reputation of transportable dwellings with an internationally touring exhibition "Living in Motion" (curated by Robert Kronenburg and produced by the Vitra Design Museum) and the "Houses of the Future" exhibition held in Sydney.

The Australian market has developed a specialist field of housing for developing areas and isolated areas, competing much less with the conventional housing industry.

In America, the trend for mobile housing continues, with one new dwelling out of every ten in the USA being a mobile home ${ }^{102}$ (over 12.5 million people are housed in mobile homes in the USA). Their image is still unpopular and there is an ever expanding market for products which make mobile homes appear more like a conventional home (eg: products to conceal the trailer part of the home, instant additions which add space and change the floor plan or elevation from the traditional rectangular box shape of the mobile home, etc). However, the elevation of transportable architecture to art status has begun to separate the transportable house from the mobile home in the public perception.

This was the first decade in many in this region of NZ that has not produced a truly transportable hydro village (or part of one, as happened at Cromwell). A large hydro project was planned at the beginning of the decade for the lower Waitaki (Project Aqua) but planning for a hydro village did not get much past investigating a site before the project was abandoned, partly due to mass-campaigning on environmental issues. Options continue to be investigated for this project.

While it would have been very interesting to see what was provided in the form of transportable accommodation for Project Aqua, it is fair to expect that today's environmental and social requirements, along with a much stricter building code than ever before, would result in a solution much like that at the second West Arm camp.

The practicalities of transportable housing today often result in products a lot less desirable than the solutions expounded in the media. Gone are the days when a

${ }^{102}$ Wallis, p13 
hydro camp could be converted into a permanent township without alteration to the buildings.

Today's portable architecture seems to fall into several different categories: disaster relief, transient solutions, construction camps and the more pricey architectural solutions to difficult sites (which often approach the cost of a conventional dwelling on a simpler site).

Container architecture has become one of the most common solutions, with many different examples of housing based on either 20 or $40 \mathrm{ft}$ shipping containers available around the world, most of which have solved the problem of transportability but are yet to resolve equally important comfort and individuality issues for the end user. These issues are critical in the success of the product, as has been illustrated in the upgrades to transportable housing made within the NZ hydro towns. 
CHAPTER TWO: METHODOLOGY 


\section{Literature Review}

Despite a proliferation of literature on the similar topics of prefabrication and post-disaster (temporary and transitional) accommodation, there is a lack of literature attending to the topic of temporary workers accommodation.

In order to assess the history of workers accommodation in NZ, the example of hydrotowns in the South Island was chosen as representative of medium to long term "temporary" construction towns. the sample was chosen as it was a uniquely continuous evolution for 50 years. Thus comparative analyses of the aspects of the designs could illuminate lessons learnt as the designs progressed. In order to analyse the case studies it was necessary to accumulate the information from multiple sources and narrate them in this thesis as a cohesive progression (which does not exist elsewhere).

The majority of literature explored in this thesis is unconventional in that it does not directly contribute to the topic of future workers accommodation, but, rather, provides material for the individual case studies and social assessments which assist toward the comparative analyses.

An investigation of existing literature shows 3 main areas of applicable study social assessments, engineering and architectural history of the dams and legislation and guidelines. The literature consulted fell into these categories as follows.

\section{SOCIAL ASSESSMENTS:}

Each of the books referred to in this section of literature examines one or two of the case studies. There is not a publication which examines all of the case studies, so these works have been used to rewrite the case studies as a progression in order to be able to analyse the accommodation comparatively.

- Hydrotown: The Social History of an Industrial Boom Settlement, by W J Campbell - a record of the people living and working in Roxburgh Hydro written while the author was working on the dam (and living in the singlemens' camp) 
during breaks from university between 1952-55. This publication is of particular importance because of its inclusion of satisfaction surveys.

- Waitaki Dammed and the Origins of Social Security by G G Natusch - records construction of the Waitaki dam and contains a chapter entitled 'Life in the Camp' which includes recollections of ex-residents and a section investigating the nearby community reaction to the accommodations.

- Dam Dwellers by Marion Sheridan - the least academic of the main texts, this book was written in retrospect by a former resident of Otematata and Twizel and records life in these single purpose towns while they were under the control of the MoWD. The fact that the author was a housewife in these towns brings a unique perspective to an otherwise male-dominated sociological history.

- People, Politics and Power Stations, edited by John Martin, investigates the planning, engineering and environmental concerns of the hydro projects in New Zealand from 1900-1990. This includes some historical secondary records of the accommodations, but mostly only describes these briefly as a sideline to the infrastructure project.

- Benmore, by Lloyd Jones, is a brief history of the Benmore Dam and Otematata single purpose town to celebrate the $40^{\text {th }}$ anniversary of the dam's construction. It includes some recollections of inhabitants of Otematata which assisted with the writing of the Otematata case study. However, the recollections are from secondary sources in many cases and hence, a little unreliable in their telling and are strongly biased towards sociological commentary.

- Several social impact assessments written by Nick Taylor, Wayne McClintock and Gerard Fitzgerald of Taylor Baines and Associates, whilst working out of the Centre for Resource Management at Lincoln College in the early 2000s were also of great assistance, particularly Fitzgerald, Gerard, "A Case Study of Manapouri”, Working Paper 21, Resource Community Formation and Change and Taylor, Nick, Fitzgerald, Gerard and McClintock, Wayne, "A Case Study of Twizel", Working Paper 22, Resource Community Formation and Change 


\section{ENGINEERING AND ARCHITECTURAL HISTORY:}

- Andrew Leach, Power Architecture: Reading the Architecture of Electricity addresses the relationship between architecture and electricity through cultural history, literary analysis and architectural design, arguing that the architecture of the dams under Frederick Newman have expressed the modernity of electrical production in language approachable by all and thus widened the discourse over future modernisation.

- By Design, by Rosslyn Noonan, is a history of the Ministry of Works from 18701970. It records the engineering and architectural history of the hydro projects, rarely venturing onto the topic of accommodation in the case studies. However, it has provided a good context for the case studies and has been utilised in many parts of this thesis.

\section{LEGISLATION AND GUIDELINES:}

Investigation of the regulations for construction camps found that the latest revision of NZ legislation in regards to the temporary housing of workers on large construction projects was the 1921 Public Works and Construction Workers Agreement ${ }^{103}$.

- 1921 Public Works and Construction Workers Agreement - provides minimum pay and accommodation standards for workers in NZ.

- Workers Accommodation: Processes and Standards - A guidance note by IFC and the EBRD. Written as guidelines by the International Finance Corporation (part of the World Bank Group) and the European Bank for Reconstruction and Development, these guidelines provide checklists and benchmarks for workers accommodation (both temporary and permanent) provided by employers. It covers needs assessments, impact assessments, design and construction standards and management policies, but provides no specific minimum standards other than referring to local legislation

- Western Australia Construction Camp Regulations - very specific minimum standards for workers accommodation within the state of Western Australia.

${ }^{103}$ See appendix A 
Many other books and publications make reference to the construction camps and single purpose towns associated with the hydro projects in NZ, but none in any great detail.

There is still no suggestion in the existing literature as to how accommodations might be planned and designed under the responsibility of private enterprises, let alone how the Resource and Building Consent applications for temporary construction accommodations on such a scale would be assessed without a framework to measure them against (ie: without a government department self-regulating its designs). The available literature gives good sociological recommendations, but avoids any design recommendations and rarely examines more than two camps in any one work.

Although the initial desire was to develop guidelines for future infrastructure construction camps and single purpose towns in NZ based on the lessons learnt from the historical precedents, the scope of that work was too large to be encompassed in a masters thesis. So this thesis lays the groundwork for future investigations by examining the historical precedents (comparing and contrasting a continuous evolution of accommodations) and analysing them for lessons learnt.

The south of the South Island provided the best reference for an investigation into the construction accommodations as there was a nearly constant flow of workers between hydro projects for over 50 years (between 1949 and 2002 the only period without hydro workers accommodations in existence in the southern part of the South Island were the years 1991-1997) and the history of these accommodations provided examples of both construction camps and single purpose towns. 


\section{Research Methodology and Framework}

\begin{tabular}{|c|c|c|}
\hline RESEARCH QUESTION & AIM & METHOD \\
\hline \multirow[t]{7}{*}{$\begin{array}{l}\text { What can we learn from } \\
\text { worker housing developed } \\
\text { around large infrastructure } \\
\text { projects in New Zealand } \\
\text { during the } 20^{\text {th }} \text { century that } \\
\text { may be used to inform } \\
\text { development of worker } \\
\text { housing in the new } \\
\text { paradigm (that is, without } \\
\text { the MoWD)? }\end{array}$} & & \\
\hline & Problem identification & $\begin{array}{l}\text { Professional interest and } \\
\text { media reporting }\end{array}$ \\
\hline & Development of framework & Literature review \\
\hline & $\begin{array}{l}\text { Identification of } \\
\text { characteristics of temporary } \\
\text { worker accommodations } \\
\text { that formed best practice in } \\
\text { NZ }\end{array}$ & $\begin{array}{l}\text { Archival research informing } \\
\text { case studies strategy to } \\
\text { identify temporary worker } \\
\text { accommodation projects } \\
\text { undertaken in NZ }\end{array}$ \\
\hline & & $\begin{array}{l}\text { Archival, secondary and } \\
\text { recollections research } \\
\text { identifying the historical } \\
\text { details and context for each } \\
\text { of the cases identified }\end{array}$ \\
\hline & & $\begin{array}{l}\text { Analyse each case against } \\
\text { the framework }\end{array}$ \\
\hline & $\begin{array}{l}\text { Identify best practice } \\
\text { elements which should be } \\
\text { carried forward into future } \\
\text { temporary workers } \\
\text { accommodation design }\end{array}$ & $\begin{array}{l}\text { Comparison and analysis } \\
\text { across the different case } \\
\text { studies }\end{array}$ \\
\hline
\end{tabular}


Developing a research methodology for this thesis was hampered by minimal existing case study reports and early enquiries revealed that the inclusion of ex-resident interviews may have been interesting, but the sample size was too small to provide a balanced overview. The research methodology thus needed to be predominantly artifactual and qualitative. Although little had been written on the design of the construction camps and single purpose towns while they were in existence, many publications included small references to them and, by combining these with the papers in the National Archives and the major texts referred to above, enough information could be gleaned to write case studies from which to make a critical assessment of the accommodation types and their evolution.

Architectural Research Methods by Linda Groat and David Wang was consulted for research methods which could assist with the developing a framework. It was also necessary at this point to consult other thesis examples in order to ascertain the success of methodologies which had been applied to similar topics. The main thesis chosen for analysis was Andrew Leach's Power Architecture, mainly due to its related topic. Although Leach's methodology was appropriate for its topic, it was found to be inappropriate for this research due to the restricted amount of literature available for this topic.

It was apparent that a combination of multiple case study and historicalinterpretive methodologies were going to be required in order to provide the history as well as analyse it in the same thesis.

The decision was made not to separate the two distinct types of accommodations (construction camps and single purpose towns) in the research as the dichotomy was largely a result of the lessons learnt in the case studies and thus they were a natural progression of the design evolution and should be compared on the same grounds.

A historical (case studies) section which would tell the story and set out the details of the case studies was necessary in order to collate the information which appears in small amounts spread through many different books and other records. A historical overview of the case studies provides the foundation for an analysis to ascertain lessons learnt. 
The analysis section immediately follows this one and utilises comparisons to make judgements as to the effectiveness of elements of the provided accommodations. A table is set out in each part, with four or five of the main issues raised on the topic used to compare and contrast the projects. The aim of this is to identify the aspects of each topic which contributed most strongly to the ongoing dialogue between accommodation providers and occupants.

The topics chosen for the comparison tables argue the success or otherwise of the accommodations and require visual descriptions and a few photos are included in this section to illustrate comparisons. These photos are then replicated in the appendices (and many other photos of interest that have not been reproduced in the main body of the text are also included there and referenced in the analyses section), where photos are grouped together under the headings of their locations to allow an overall view of the project discussed. Although the repetition of illustrations is unusual in a masters thesis, the lack of common knowledge and documentation of the topic translated into the need to fully describe the projects as discussed above. Photos are provided in the appendices outlining the case studies in order to illustrate the qualitative contextual paradigm.

The appendices therefore, although somewhat lengthy, form an essential visual reference for the main body of the work.

\section{Fieldwork}

Fieldwork formed an important component of the research for this topic. All of the sites were visited multiple times over the period of writing. For obvious reasons, where the accommodations ceased to exist in situ the site became the primary subject of the photos and the accommodations were photographed in their current incarnation in cases where these were identifiable and/or accessible.

For all projects historical photos from various sources have been included to provide an illustration of their use during the period studied. Where the accommodations are no longer in situ, the historical photographs and written descriptions have been used as primary evidence and any photos of the buildings being reused have been 
referenced as of secondary importance as they are out of the context referred to in this thesis.

\section{Further Research}

Further research was required to uncover information not available in either the public or university libraries. For this historical documentation the primary sources investigated were Archives New Zealand and the Alexander Turnbull Library.

Research at Archives New Zealand (the majority of which was done at the Dunedin branch, which covers the regions studied) produced records of the design of the accommodations on the majority of projects. However, in most cases the records were incomplete with references being made to further records either located with Meridian Energy, with ex-NZED files in Wellington, with Housing NZ files or even with other government departments where transition of responsibilities has occurred. In many cases upon investigation the author was informed that any such files would be located "in storage" and were unrecoverable without provision of a file number and date of deposit. Therefore, several strands of research were incomplete and thus not included in the analysis (for example, it was not possible to recover records as to the intention of the house designs for the case studies).

The Alexander Turnbull Library collections were invaluable for providing photographic evidence that was not available elsewhere, particularly for the earliest case studies.

\section{Triangulation/Verification}

Triangulation of information was a constant problem in this research due to the number of reliable sources available for information on each case study. In most cases, information has not been included where it was unverifiable. However, in a few instances information has been noted as questionable due to the limitations of the sources where the information was of minor importance or where it was necessary in order to provide a full profile of an aspect of the design. 
In many cases at least one source of verification of physical descriptions was provided by historical photos, again reinforcing the importance of such a large appendices section.

\section{Analysis}

Analysis is made of traits of each part, utilising a table to compare and contrast the conditions at each project. These traits are then analysed in terms of both changes through the progression of camp evolution and also in the context of current conditions (for example, improved infrastructure, including road and other access provisions).

Where judgements are made according to suitability or best practice, these are made according to a criteria of suitability for today's conditions.

The aim of the analysis is to provide information as to what has been provided in past infrastructure construction camps and what may be of use to either those planning future large scale construction camps or those drafting legislative guidelines for temporary construction camps (such as that in Appendix I) 


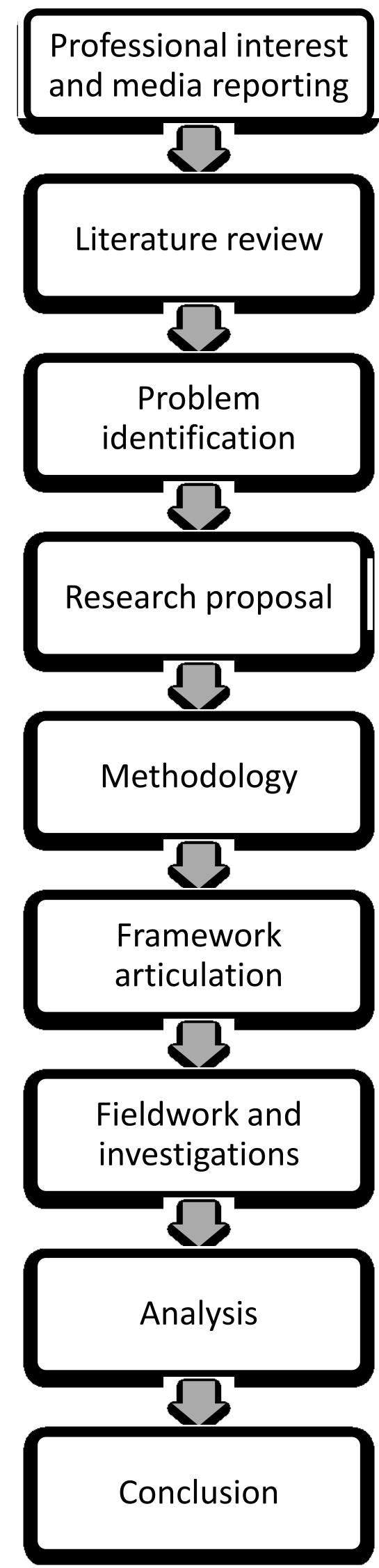


CHAPTER THREE: ANALYSIS 


\section{SITE}

\section{Geography}

The earliest of the hydro projects' accommodation sites discussed in this research, Waitaki and Roxburgh, had similar geography - rocky terraces on the banks of large rivers, making the move between sites quite easy on the expectations of the residents. In contrast, Otematata, Twizel and Cromwell were all located on flat land, further back from the rivers on which construction was being undertaken.

The singlemens' camps at Waitaki, and earlier, had been made up of very small, flexible structures (usually tents), which were easily placed on slightly uneven ground and for which one man could easily and rapidly cut and/or fill a flat(ish) base, if required. However, with the inclusion of families into the camps the houses grew in size, as did the camps, and it became necessary to move away from locating camps and towns on the river banks and onto flat sites in order to avoid the need for permanent (subterranean) foundations, which would have conflicted with the planning intentions for Otematata and Twizel to be completely removed after they had fulfilled their functions. (Most houses and huts were placed on concrete blocks for foundations). Cromwell was an entirely different project, with permanent housing (as an extension from the existing town) planned from the start.

The housing and accommodation sites for the Manapouri Tailrace Tunnels projects were also on the flat and on the edge of large bodies of water (both the lake and the sound), but the largest impact of the accommodation sites of the Manapouri Tailrace Tunnel projects were their locations in a national park of significant importance, thus severely limiting the site selection for the accommodation. These sites were the most extreme in terms of geography, requiring a large amount of clearing of vegetation (inside a national park as well as causing the usual concerns over land destabilisation) and filling and stabilising of swampy land.

At all sites the most important impact of the geographical conditions on the accommodation, of course, was that it was one of the necessitating factors of the accommodation. If these sites had been less remote there would have been no need 
for the accommodation as the workers would have been able to commute to work from existing settlements.

So, while the earlier camps required some excavation, it was not on a large scale due to the size of the accommodations. As the houses grew larger the accommodation sites were moved further from the work sites onto flat land. This allowed for more separation of the houses, which in turn increased the footprint of the accommodation areas overall. At the same time, private vehicle ownership was increasing, requiring parking in accommodation areas and an upgrade in road qualities. It was also the increase in transportation availability which allowed the move for accommodation sites to be located further away from the work site (allowing more choice in site selection).

\begin{tabular}{|c|c|c|c|c|c|c|}
\hline & & SLOPE & EARTHWORKS & ACCESS & VEGETATION & SITE RISK \\
\hline WAITAKI & & $\begin{array}{l}\text { terraces and } \\
\text { gentle slope }\end{array}$ & $\begin{array}{l}\text { Some terracing, some levelling, } \\
\text { subterranean foundations for } \\
\text { permanent houses }\end{array}$ & \begin{tabular}{|c|} 
Rail for \\
materials, \\
very limited \\
transportation
\end{tabular} & $\begin{array}{l}\text { Site cleared - } \\
\text { riverside }\end{array}$ & $\begin{array}{l}\text { Appears to be some } \\
\text { slip risk above lower } \\
\text { terrace }\end{array}$ \\
\hline ROXBURGH & & Gentle slope & $\begin{array}{l}\text { Levelling, subterranean foundations } \\
\text { for permanent houses }\end{array}$ & $\begin{array}{l}\text { Limited } \\
\text { vehicular }\end{array}$ & $\begin{array}{c}\text { Site cleared - } \\
\text { riverside }\end{array}$ & Minimal slip risk \\
\hline OTEMATATA & & Flat & $\begin{array}{l}\text { Levelling, subterranean foundations } \\
\text { for permanent houses }\end{array}$ & Vehicular & \begin{tabular}{|} 
site cleared - \\
tussocky \\
grazing land
\end{tabular} & None \\
\hline \multirow[t]{3}{*}{$1 \mathrm{MTT}$} & West Arm & $\begin{array}{c}\text { Gentle slope, } \\
\text { swamp }\end{array}$ & $\begin{array}{c}\text { Some terracing, levelling, filling of } \\
\text { boggy ground }\end{array}$ & Boat & \begin{tabular}{|c|} 
Site cleared - \\
national park
\end{tabular} & Flooding \\
\hline & $\begin{array}{l}\text { Deep } \\
\text { Cove }\end{array}$ & Mostly flat & Levelling & Boat & \begin{tabular}{|c|} 
Site cleared - \\
national park
\end{tabular} & $\begin{array}{c}\text { Flooding and some } \\
\text { slip risk }\end{array}$ \\
\hline & Manapouri & Mostly flat & Levelling & Vehicular & $\begin{array}{l}\text { Site partially } \\
\text { cleared - } \\
\text { grazing land }\end{array}$ & None \\
\hline TWIZEL & & Flat & Basic levelling & Vehicular & $\begin{array}{c}\text { Site cleared - } \\
\text { tussocky } \\
\text { grazing land }\end{array}$ & None \\
\hline CROMWELL & & Flat & $\begin{array}{l}\text { Basic levelling and subterranean } \\
\text { foundations }\end{array}$ & Vehicular & $\begin{array}{l}\text { Site cleared - } \\
\text { grazing land }\end{array}$ & None \\
\hline 2MTT & West Arm & $\begin{array}{c}\text { Pre-prepared } \\
\text { for } 1 \mathrm{MTT}\end{array}$ & Levelling of hostel footprint & Boat & $\begin{array}{l}\text { Hostel } \\
\text { footprint } \\
\text { cleared - } \\
\text { regenerating } \\
\text { natives }\end{array}$ & Flooding \\
\hline
\end{tabular}

Table 1: Geographical assessment of accommodation sites ${ }^{104}$

Slope: this refers to the slope of the site when it was chosen. The steeper the slope, the more earthworks that will be required. This both increases the cost of site

\footnotetext{
${ }^{104}$ Note: this assessment is made purely on the accommodation sites, exclusive of the work sites
} 
preparation and also requires permanent changes to the landscape which are hard to remedy when/if the accommodations are removed and site restitution is required. The earliest sites were on gentle slopes and terraces, but the sites became flatter as both vehicular transportation and services were improved and it was no longer necessary to build right next to the construction site. In turn, the larger accommodations that were possible on flatter sites promoted a need for levelling of larger areas.

Earthworks: this refers to how much earth moving was required to prep the sites this includes cutting, filling, retaining, subterranean foundations, etc. Earthworks were minimal in the earliest camps, but at Otematata and Twizel the improvement in mechanical earthmoving machinery enabled an increase in both levelling and also in digging channels for underground services and road formation.

For $1 \mathrm{MTT}$ there was a large amount of earthworks required. Mostly this was as a result of the swampy conditions and the need for a road between the two work sites at West Arm and Deep Cove. Combined with underground services and wharves for deliveries, a lot of digging, filling, retaining, rock blasting and post boring was required.

Access: this is an indication of how easily accessible the site was for occupants as well as for placement of accommodations. Ideally access should be reasonably flat in order to reduce earthworks required for road formation.

Vegetation: where vegetation has been removed from the site, the quality and/or use of that vegetation has been judged as well as the effort required to remove the vegetation. Tussocky grazing land is of low value (ie:both financially and conservation-wise) and required minimal effort for removal, riverside trees require a lot of effort to remove although they are of little value, whereas national park trees are of high value (ie: they take a long time to regrow and are often protected by DoC and various conservation groups) and take a large amount of effort to remove. A plan should be agreed prior to locating the accommodations in regards to existing and potential vegetation. Ground cover and shrubs (including tussock, gorse, etc) or trees may be stabilising slopes, of historical significance, or have a number of other impotant aspects which require consideration. Most of the sites discussed in this 
thesis had minimal vegetation prior to occupation. These sites have rejuvenated to an extent, although they now also include non-native species which were planted by occupants during the project. At the other end of the scale are West Arm and Deep Cove, where the vegetation on the accommodation sites was predominantly native and protected. These sites were protected from the time of planning in order to minimise damage and the chances of introduction of non-natives onto the sites. This is further discussed in the Environmental Protection section.

Site risk: this is judged on visible site risks, therefore fault lines, bearing capacities, etc, are not included. Flood risk is the most common as the sites are all close to major hydro projects. Slips have occurred in some of these examples, but damage has been minimal as the majority of sites are on flat areas of land.

All of these sites are either on or close to major fault lines, but earthquake risk has not been a large issue as most of the accommodations have been timber framed and small enough not to be at huge risk of collapse or of causing loss of life. The brick chimneys on the early buildings were the major exception to this.

The case studies all required earthworks to varying extents for their accommodation sites, often due to slopes and vegetation. As the towns evolved they required larger amounts of earthworks (ie: more site disruption) for houses, larger singlemens' camps and for roads and services.

While improvements in transportation made for greater site disruption due to increased private vehicle ownership and the resultant need for sealed roads and paved areas, it also led to greater options in the location of accommodations and the associated move to flatter ground away from project sites, thus reducing accommodation site risks. 


\section{Climate}

Waitaki, Otematata and Twizel were close in proximity and had similar climates. Summers were hot and dry, with frequent drought conditions, exacerbated by hot Norwester winds. Winters were cold, with snow falling in the townships several times each winter and severe frosts (including hoar-frosts and inversion layers). The inland winters were very harsh, with icicles hanging from the eaves of houses and the contents of houses freezing in Otematata (where there was no insulation in the houses $)^{105}$. These extremities of weather prompted the early design changes away from tents and towards more solid (and waterproof) structures and were also to drive the later request for insulation to be added to the houses. The snow and wind loadings in these townships further promoted the use of modular components for the transportable houses, as these were believed to have the strongest bracing of any of the transportable systems.

By installing solid fuel heating, not only were the accommodations less easily transportable, but the occupants were thereby encouraged to find fuel in the surrounding environs, thus exacerbating site damage.

At the sites in Fiordland, at either end of the Tailrace Tunnels projects, the summers were not as hot, but the winters also brought snow and the rain fell year round, reaching an average of around 6 metres per year at Deep Cove (rain fell 62\% of the time at Deep Cove ${ }^{106}$ ). This climate promoted the use of hostels (as opposed to huts) in order to reduce both the impact on the sites (which were more easily damaged when wet) and the need to go outside when moving between living areas (thus increasing the comfort of the occupants by keeping them dry and minimizing exposure to sandflies).

Those who commuted daily from Manapouri may have lived in individual houses with their families, but may have regretted this during the often wet and rough (and frequently bone-chillingly cold) daily commutes across Lake Manapouri.

The climate alone is responsible for many of the negotiations between the head contractors and the unions on these sites. The move to Twizel was delayed by the

\footnotetext{
${ }^{105}$ Sheridan, p18

${ }^{106}$ Stolz, HJ and Warren, FT, p24
} 
issues of electricity for heating and house upgrades for the climate, much of the staff turnover on 1MTT was blamed on the climate ${ }^{107}$ and many pages of the Otematata references refer to the hardships involved with the winter climate.

Winds were also a major issue on some sites, with the flat land which provided ideal housing sites often having no natural wind breaks. As houses began to be placed further apart they lost much of the ability to act as wind and frost breaks for each other.

The Joint Planning Committee for Cromwell was aware of the issues involved in planning for the climate and allocated a lot of time addressing it ${ }^{108}$. The fact that Cromwell was to be permanent accommodation was a motivating factor in allowing more indepth town planning, as opposed to the earlier transportable single purpose towns which were deemed temporary at the outset of planning.

Earlier camps, such as Roxburgh and Waitaki, had little planning allowed for the climatic extremes, other than the introduction of timber walls and malthoid roofs to replace tents to better suit the longer terms expected of the construction projects.

\footnotetext{
107 "Any description of the weather encountered in the project area could not be as deplorable as the reality. The weather played a considerable part in the high labour turnover throughout the life of the project. Meteorological data at the beginning of the project stated that 250 to 300 inches of rain could be expected each year at Deep Cove. Project records kept from 1 November, 1963, through 20 September, 1969 (2151 days), verified this soggy prediction. 1342 rain days (62\% of total number of days) brought 1267 inches of rain. That's more than 100 feet by anyone's ruler. It caused rock slides that blocked the roads, floods (15.75 inches on 25.4.67) and many tempers were lost in addition to the dollars and manhours." ibid

${ }^{108}$ Recommendations included "to this end project houses should ideally be specially designed for the unique climate of Central Otago in additions to being constructed of permanent materials which harmonise with the colours of the surrounding landscape and with each other .....the strong winds of the spring equinox and accompanying dust and the heat of summer give the theme for the landscape design of the town particularly in relation to pedestrian movement. Pedestrian/cycle ways should be sheltered by a canopy of deciduous trees from the summer sun, but which also lets through the sun in winter months. They should also be protected by substantial shrub planting at ground level to shelter people from the winds and dust during spring" Joint Planning Committee, p18-19
} 


\begin{tabular}{|c|c|c|c|c|c|c|c|}
\hline & & $\begin{array}{c}\text { ANNUAL } \\
\text { TEMP RANGE }\end{array}$ & HEATING & $\begin{array}{l}\text { ANNUAL } \\
\text { RAINFALL }\end{array}$ & RUNOFF & WIND & WIND BREAKS \\
\hline WAITAKI & & $\begin{array}{l}\text { Similar to } \\
\text { Otematata }\end{array}$ & Solid fuel & $\begin{array}{c}450 \mathrm{~mm} / 100 \\
\text { days }\end{array}$ & Natural runoff & W & $\begin{array}{l}\text { Some from } \\
\text { terraces, some } \\
\text { from close } \\
\text { proximity of } \\
\text { buildings }\end{array}$ \\
\hline ROXBURGH & & $\begin{array}{c}\text { Mean }=11 \text { Min }=- \\
4 \mathrm{Max}=30\end{array}$ & Solid fuel & $\begin{array}{c}500 \mathrm{~mm} / 110 \\
\text { days }\end{array}$ & Natural runoff & W & $\begin{array}{l}\text { Some from existing } \\
\text { vegetation, some } \\
\text { from close } \\
\text { proximity of } \\
\text { buildings }\end{array}$ \\
\hline OTEMATATA & & $\begin{array}{c}\text { Mean=11 Min=- } \\
6 \text { Max=31 }\end{array}$ & Electric & $\begin{array}{c}450 \mathrm{~mm} / 100 \\
\text { days }\end{array}$ & $\begin{array}{c}\text { Minimal natural } \\
\text { runoff }\end{array}$ & W & Limited protection \\
\hline \multirow[t]{3}{*}{$1 \mathrm{MTT}$} & West Arm & $\begin{array}{c}\text { Mean=9 Min }=-4 \\
\text { Max }=29\end{array}$ & Infra-red & $\begin{array}{c}4000 \mathrm{~mm} / 220 \\
\text { days }\end{array}$ & $\begin{array}{l}\text { Minimal natural } \\
\text { runoff }\end{array}$ & NW & $\begin{array}{c}\text { Little from existing } \\
\text { vegetation, some } \\
\text { from close } \\
\text { proximity of } \\
\text { buildings }\end{array}$ \\
\hline & $\begin{array}{l}\text { Deep } \\
\text { Cove }\end{array}$ & & $\begin{array}{c}\text { Ship generator/i } \\
\text { infra-red }\end{array} \mid$ & $5600 \mathrm{~mm}$ & Natural runoff & W & $\begin{array}{l}\text { Some from existing } \\
\text { vegetation, some } \\
\text { from close } \\
\text { proximity of } \\
\text { buildings }\end{array}$ \\
\hline & Manapouri & & Electric & $\begin{array}{c}1300 \mathrm{~mm} / 150 \\
\text { days }\end{array}$ & Natural runoff & & Limited protection \\
\hline TWIZEL & & $\begin{array}{c}\text { Mean=9 Min=- } \\
10 \text { Max=32 }\end{array}$ & $\begin{array}{l}\text { Solid fuel + } \\
\text { electric }\end{array}$ & $\begin{array}{c}700 \mathrm{~mm} / 130 \\
\text { days }\end{array}$ & $\begin{array}{l}\text { Minimal natural } \\
\text { runoff + drains }\end{array}$ & NW & Limited protection \\
\hline CROMWELL & & $\begin{array}{c}\text { Mean }=10 \text { Min }=- \\
7 \mathrm{Max}=32\end{array}$ & Mixed & $\begin{array}{c}430 \mathrm{~mm} / 120 \\
\text { days }\end{array}$ & $\begin{array}{l}\text { Stormwater } \\
\text { drains }\end{array}$ & $\mathrm{N}$ & \begin{tabular}{|} 
Fences and new \\
plantings provided \\
some protection
\end{tabular} \\
\hline 2MTT & West Arm & $\begin{array}{c}\text { Mean }=9 \text { Min }=-4 \\
\text { Max }=29\end{array}$ & Electric & $\begin{array}{c}4000 \mathrm{~mm} / 220 \\
\text { days }\end{array}$ & $\begin{array}{l}\text { Minimal natural } \\
\text { runoff }\end{array}$ & NW & $\begin{array}{c}\text { Some from existing } \\
\text { vegetataion, } \\
\text { covered walkways } \\
\text { and use of hostels }\end{array}$ \\
\hline
\end{tabular}

Table 2: Climatic assessment of accommodation sites

Temperature range: These are averages taken from climate data over the period of the project, rounded to the nearest degree Celcius ${ }^{109}$. There is not a lot of spread over the data. Most sites have a higher minimum temperature in correlation with a higher average rainfall, the exception being Twizel, which is further inland than the other sites and situated in a large basin, which creates a microclimate of its own. Heating: This identifies the type of heating provided. Solid fuel heating is undesirable as a result of the promotion of clearance of vegetation in the surrounding area, thus reducing protection from winds and shelter from frosts. This can also lead to destabilisation of surrounding slopes. The heating at Deep Cove and West Arm accommodations were planned with this in mind. However, in some of the photos of the sites included in Appendix E (1MTT) it is possible to see the

${ }^{109}$ Climate data taken from www.cliflo.niwa.co.nz , stations 12482 (West Arm Jetty), 5428 (Manapouri), 5425 (Manapouri West Arm 1), 4137 (Deep Cove 1), 5119 (Lake Waitaki), 5116 (Otematata), 4995 (Twizel), 5621 (Roxburgh), 5526 (Cromwell MWD) 
earliest buildings at the sites which have brick chimneys, indicating solid fuel heating.

While the climate is not able to be changed, aspects of the design which respond to the climatic conditions are able to be planned to suit the site. This is why the type of heating is included in the climatic data table. If accommodations are planned to be temporary then it follows that some site protection should be included in the planning in order to reduce permanent scars.

Rainfall: These are averages taken from climate data over the period of the project, rounded to the nearest $50 \mathrm{~mm}$ or 10 days. The data is tabled as average annual rainfall and average annual number of days on which rain fell. There is a huge difference between the amounts of rain and the number of days it falls on between the Otago and the Fiordland sites.

Runoff: Natural runoff is preferable to drains in temporary locations in order to reduce the amount of excavation and groundworks required on site. However, it is preferable to have drains than to have ponding water on site. To this end, careful site planning is required to avoid the pitfalls of such problems. For example, for 2MTT accommodations at West Arm boardwalks were raised off the site, allowing transitions between modules unaffected by groundwater (and, at the same time, reducing damage to site by foot traffic over wet ground.

Wind: The predominant wind direction has been shown here in order to provide information as to where protection would have best been in place on each site Wind breaks: Wind breaks were not as necessary in the early projects, where the accommodation was closely located and provided both thermal and wind insulation to each other. However, as families became more predominant in the single purpose towns, the houses were allocated sections which required further separation of the buildings. In many cases any local vegetation had already been removed in order to make site levelling easier and this also acted to reduce any protection from climatic conditions.

These accommodation sites represent some of the wettest and coldest locations in NZ. The response to the climatic conditions in the design of the accommodations 
has sometimes reduced transportability of the buildings and occasionally exacerbated site damage. The protection from the climate provided by close proximity of the accommodations was reduced significantly from Roxburgh onwards, yet it was not replaced with considerable materials upgrades until Twizel.

Worker turnover rates have been influenced by climatic conditions and it was not until the later camps and town (Twizel, 2MTT, Cromwell) that the accommodation standards were sufficient to begin counteracting this. 


\section{Environmental Protection}

Restitution or repair of the accommodation sites became more important as the camps (and single purpose towns) progressed. At Waitaki the timber houses, huts and hostels were removed, leaving only the concrete houses for the dam operation staff. The site there is now only visible to those looking for it.

At Roxburgh again the timber houses, huts and hostels were removed. However the site is still minimally visible at Roxburgh, mainly due to the traffic loading (although the roads were not sealed) and the sewerage system which was piped underground, as well as the non-native trees which were introduced.

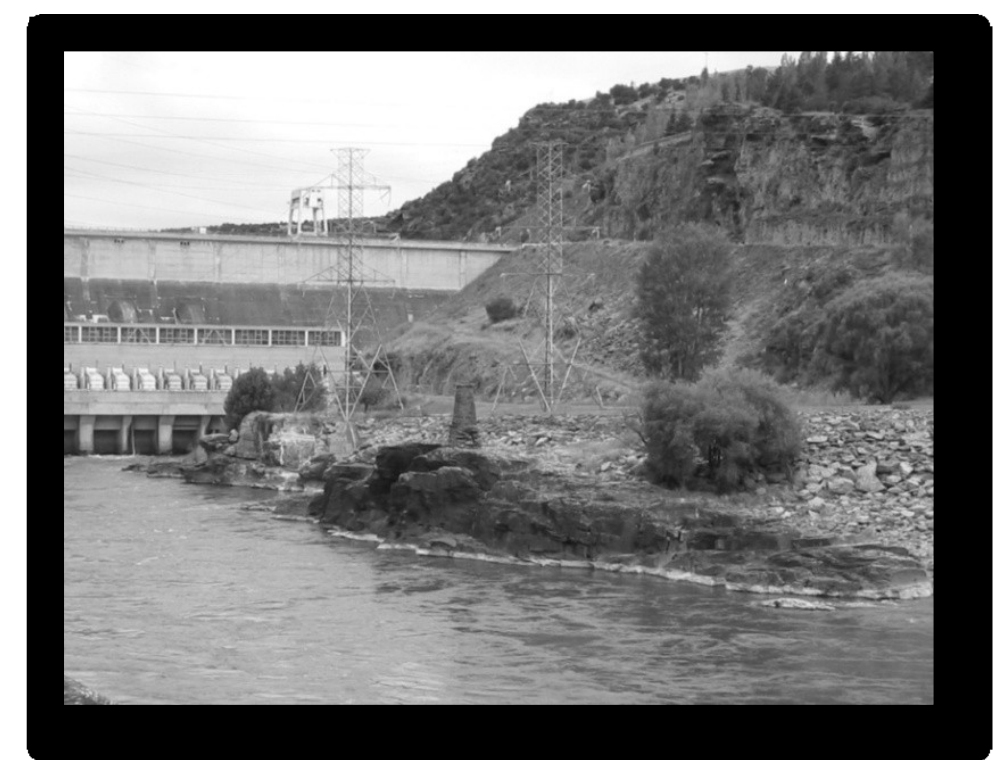

Figure 28: Roxburgh Hydro village site, 2005

At Otematata the timber huts and hostels were cleared, but the permanent houses were left in place for the Electricity Department workers and the community successfully petitioned to save half the town from demolition and/or removal. The roads at Otematata had been sealed and, despite having been torn up and the land returned to grazing, their locations are still highly visible (see fig 29), as are the gardens planted by the occupants.

Ironically, the hydro village at Otematata had a very large nursery, but this was used to cultivate trees for landscaping around the new lakes rather than for regenerating the site. 


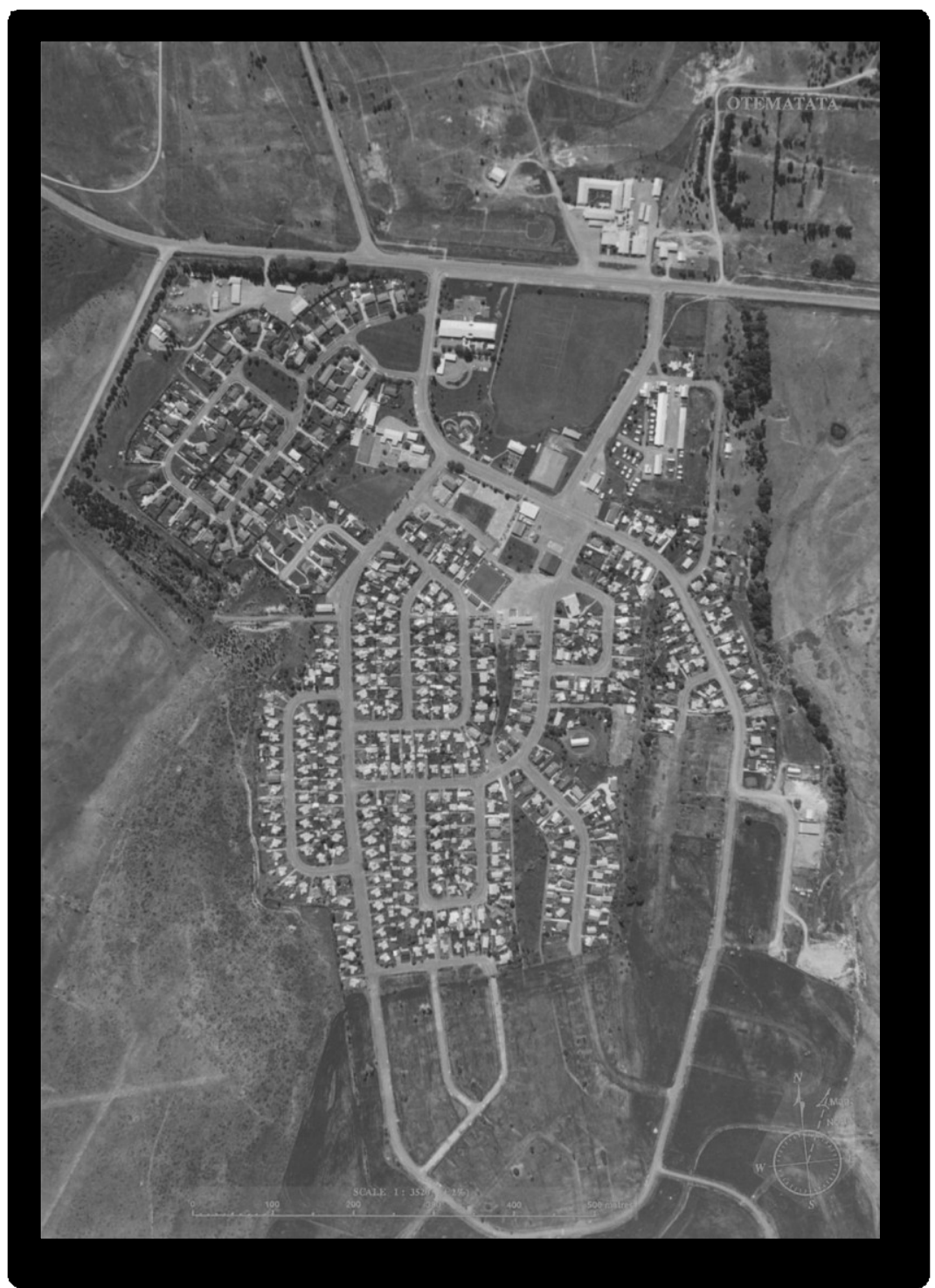

Figure 29: Aerial photo of Otematata, 2004

- note damage to the land at the top of the photo, this is where huts and hostels were located. Note also the damage to the site in the bottom quarter of the photo where roads are still highly visible despite have been torn up c. 1970

East-west axis delineation, more established planting in Rata Ave (permanent houses) at top left

Twizel hydro village was located in a harsher landscape (the government purchased part of Ruataniwha Station in 1965 to locate Twizel on) than the previous hydro villages and was thus harder to damage. Twizel housing was retained at the end of the project and the location of the huts and hostels which were removed was designated an industrial area, covering over any sign of site damage. 


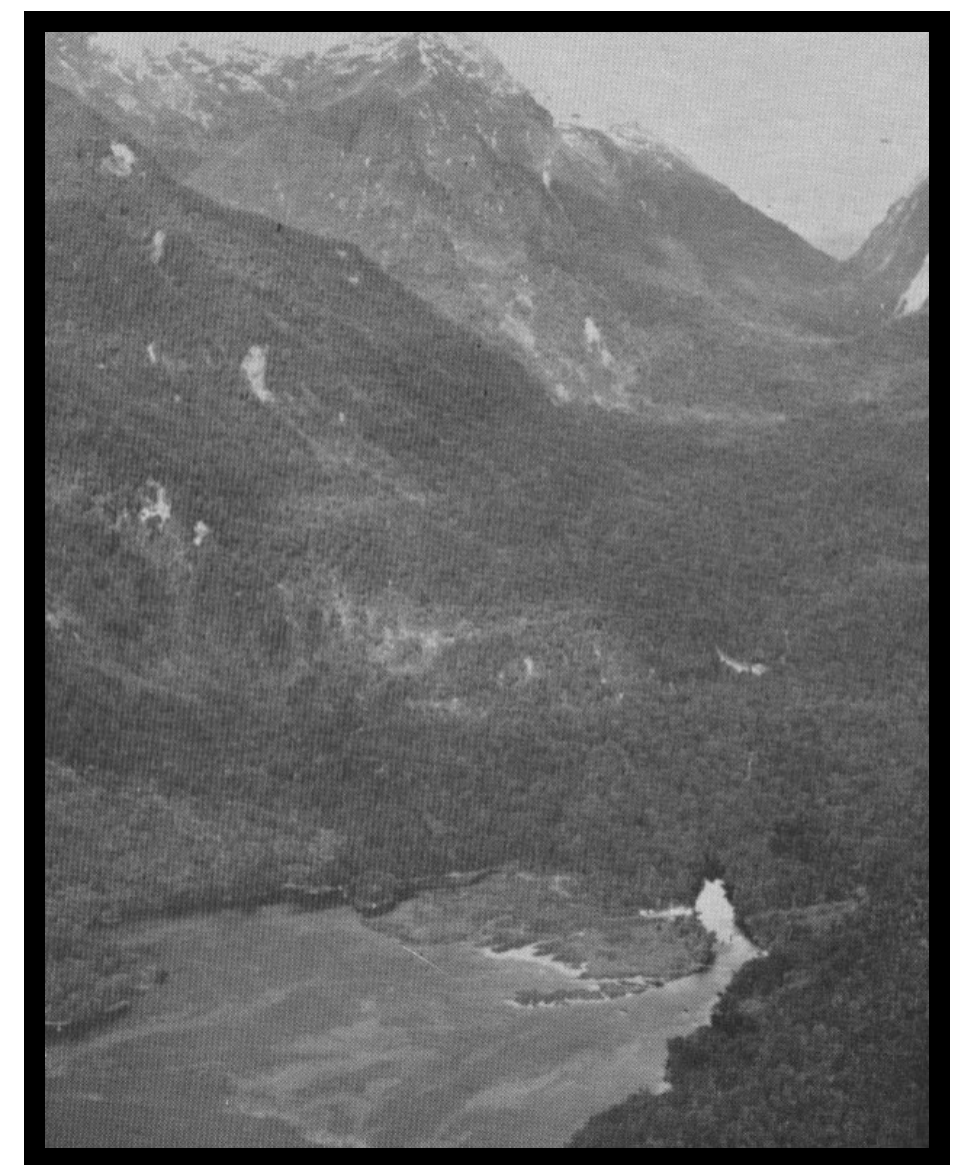

Figure 30: Deep Cove prior to the beginning of construction (Photo by the Ministry of Works)

Protection of the site suddenly became a very large issue when the 1MTT project began being planned in the Fiordland National Park ${ }^{110}$. Outstanding natural landscapes and native bush such as that at Deep Cove generated a lot of public interest and pressure on the government to ensure that damage was kept to a minimum.

\footnotetext{
${ }^{110}$ Leach (p130) acknowledges that the Hydroelectric Design Office "enjoyed relative freedom all the way through to the design of Manapouri (1968-73) when rigid legislative environmental concerns [were] introduced; before this, engineers and architects were under looser guidelines" going on to quote Frederick Newman (in charge of the architectural work of the MoWDHydro Design Office from 1948-56) on his impressions of the Whakamaru power project in the North Island "When I first saw the virgin site my impression was one of awe. How could man spoil such an outstandingly beautiful piece of nature. However, life and work had to go on; the station is finished and has replaced the romantic gorge with a lake upstream and a piece of architecture at the tail-water side" (from Newman, F, "Architecture in Hydro Design" in Journal of the New Zealand Institute of Architects, Vol 26, No 3, April 1959, p 73)
} 
The year 1960 marked the popularisation of conservation in NZ. Conservation groups began to flourish and find new support throughout the country. Many of these new groups turned their attention to the Manapouri proposals in the early years and the Government responded in 1962 by establishing the Nature Conservation Council and Manapouri was the first big issue on its agenda ${ }^{111}$-particularly the raising of the lake levels, but also considering the impact of construction and housing of the workers in the Fiordland National Park.

The problem was partially addressed by the decision to purchase the TSMV Wanganella for use as accommodation for the workers. However, she also introduced a new set of environmental problems:

- The Wanganella was not fumigated until after she had docked, allowing pests free access to Fiordland National Park;

- When the silverware was deemed undesirable for the canteen it was thrown overboard into Doubtful Sound;

- Large numbers of beer cans were often thrown overboard;

- The weather was frequently prohibitive to sending the garbage barge all the way out to the Tasman Sea and garbage often got dumped around the corner in Doubtful Sound

When accommodation space on the Wanganella ran out it became necessary to introduce a hostel and, eventually, huts. The hostel was gifted to the Department of Conservation (DoC) when the project finished. The huts had to be removed.

A road had been built early in the project (1963-5) over the Wilmot Pass to West Arm where barges could carry goods in and out from. This was also extremely useful in transporting workers in and out of Doubtful Sound, giving the men the opportunity to return to Te Anau during their days off, thus also reducing potential damage to the surrounding area from men going exploring to cure boredom.

On the other side of the Wilmot Pass, at West Arm, environmental concerns seemed to carry less weight (see Appendix E) during 1MTT. The flat land was cleared and a large number of huts and a hostel were installed. While work was

${ }^{111}$ Peat, p 7 
going on tailings were dumped near the camp, thus ensuring that even further damage was done to the site. Once the huts were removed this land did not recover.

In contrast, consideration for the sites on which the transportable Manapouri and Twizel housing was to be placed temporarily at Cromwell was clearly identified at the planning stage, such as this from the District Planner :

\section{"POSSIBLE FUTURE USE OF THE AREA}

Consideration was given at early concept stage to providing a framework structure for future use of the area once houses (and some services) are removed. There are numerous possibilities ranging from simply landscaped open space to utilising a planned area of landscaping with interspersed open spaces (spaces occupied by houses previously) for use as formal caravan parking, holidaying, etc. Any landscaping done around and within housing groups would add weight to this final use. We ask Council to consider this point and make a decision on final use before final design is completed"112

When the Second Manapouri Tailrace Tunnel (2MTT) was in the planning stage the public again submitted concerns in regards to the site. This time they were more successful.

Before construction was begun around 250,000 seeds from native plants in the area were collected and sent to Te Anau for propagation. During construction top soil and river flat soil were collected to lay over the site once the hostels were removed and around $5 \%$ of the total $2 \mathrm{MTT}$ construction budget was spent on environmental concerns. In addition to this, an Environmental Manager was appointed (Beth Masser) and monthly environmental audits were carried out by Meridian Energy as well as initial weekly, and later monthly, inspections by DoC.

No huts were allowed, all accommodation was in hostels which were raised off the ground on foundation blocks and connected to each other and the recreational facilities by elevated walkways, thus reducing impact on the site. The hostels were also designed to be easily installed and removed. Paths were created around the accommodation and work areas and signs were posted reminding everyone to stay on the paths. And a wastewater treatment system was installed at Deep Cove to ensure that the Deep Cove marine environment was protected.

${ }^{112}$ Moen, p4 
Meridian Energy stated that they believed that there would be no visual scars left on the site by 2009 , but a DoC representative has stated that they believe that the regeneration is occurring much more slowly than was forecast ${ }^{113}$.

In 2001, the project was named as one of six global finalists in the environmental section of the Financial Times Global Energy Awards. The project was commended for its sensitivity to the natural environment and its positive impact on global warming.

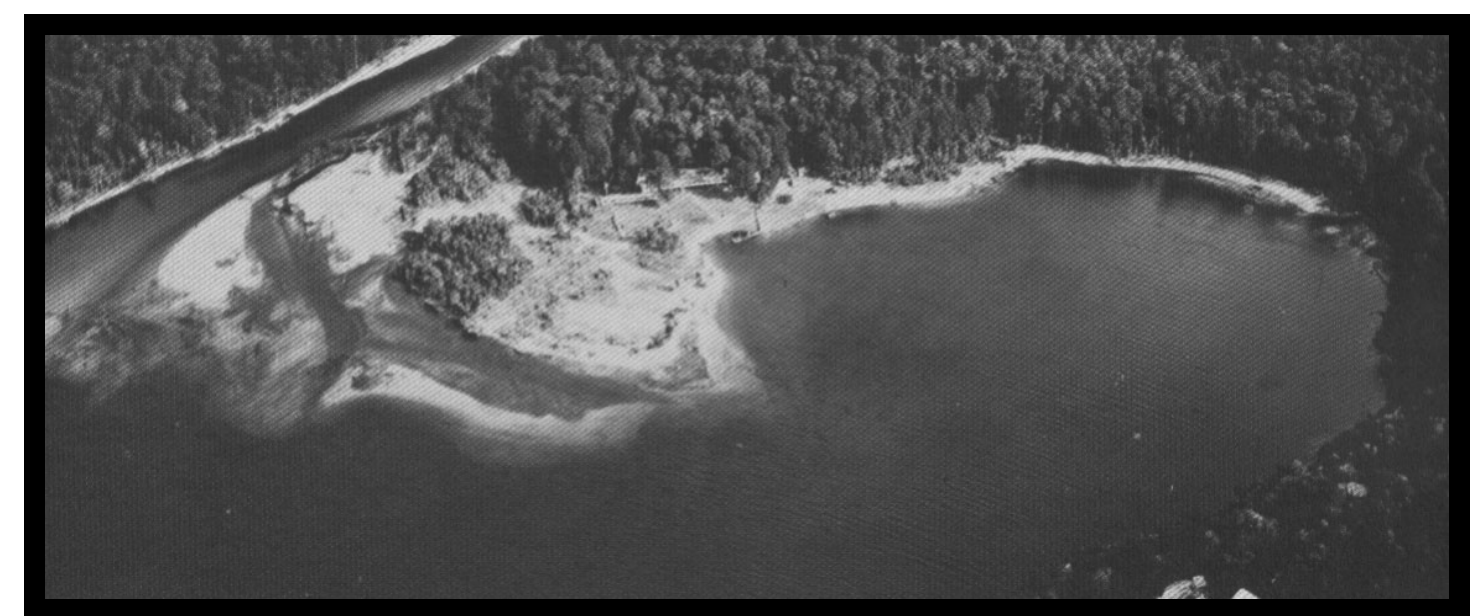

Figure 31: West Arm prior to the beginning of 1MTT construction

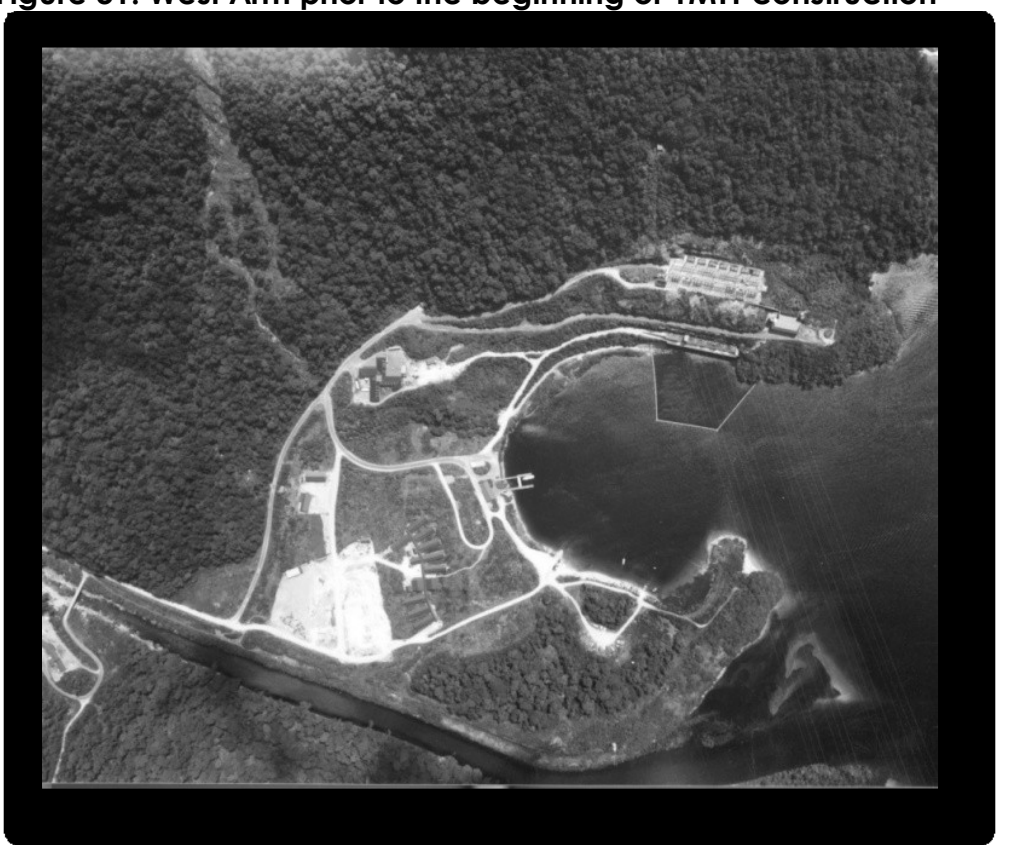

Figure 32: 2MTT West Arm camp site, c 1999

\footnotetext{
${ }^{113}$ in an interview with the author at the DOC office, Te Anau, in 2005. The person who made this statement works for DOC and requested that the statement not be attributed to them
} 


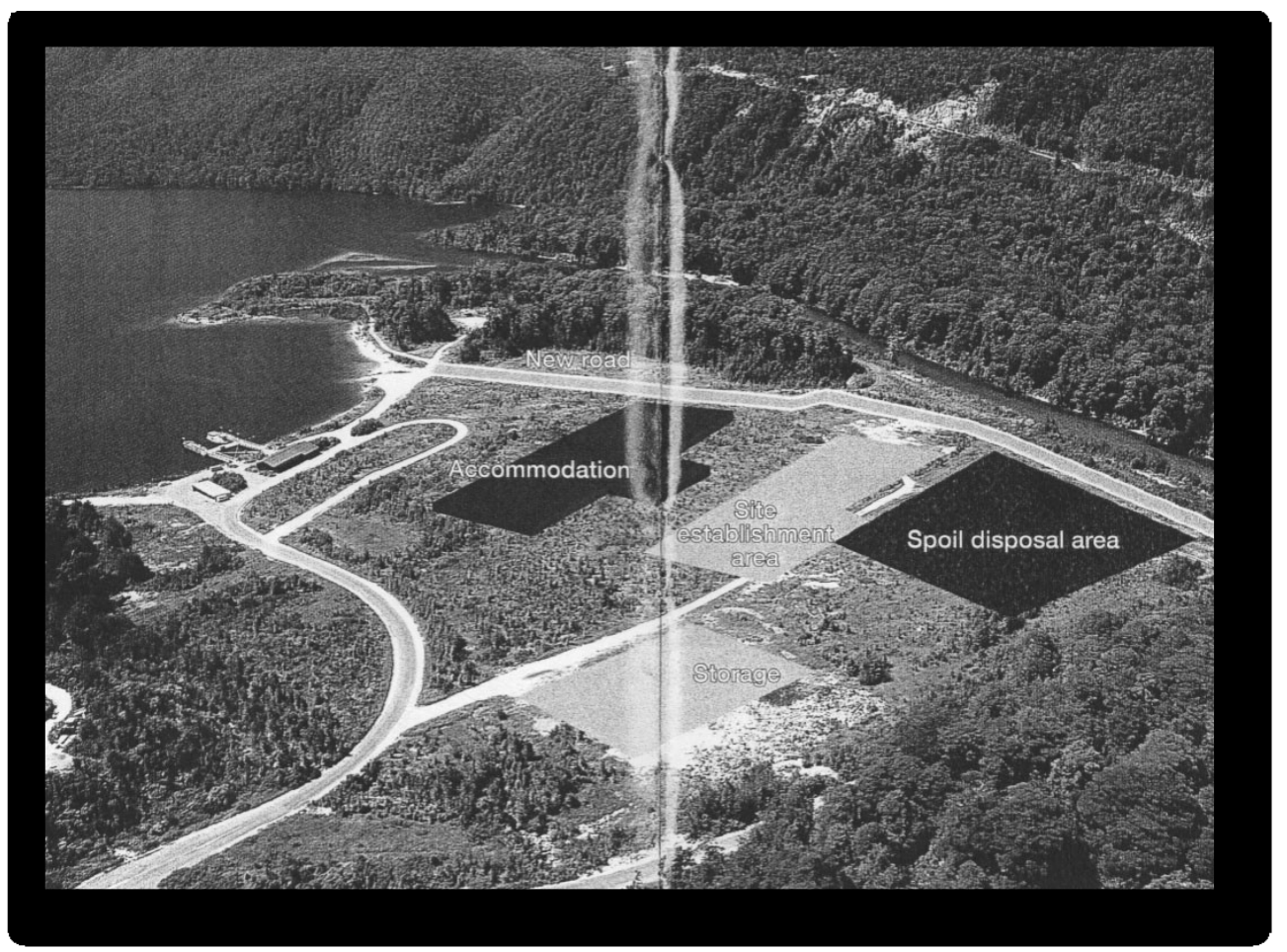

Figure 33: West Arm site under regeneration, 2002

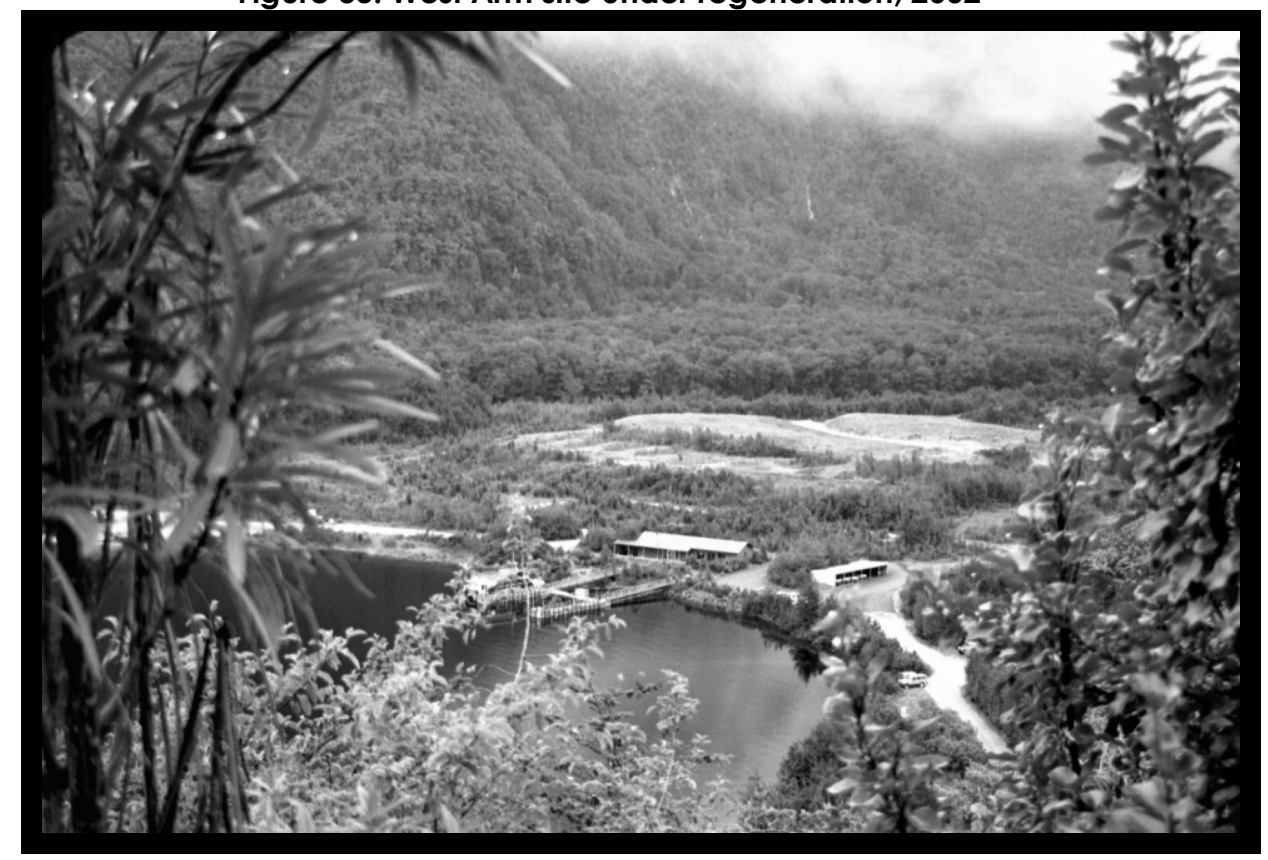

Figure 34: West Arm site regenerating, 2004 


\begin{tabular}{|c|c|c|c|c|c|}
\hline & & $\begin{array}{l}\text { Planting } \\
\text { and } \\
\text { gardens }\end{array}$ & $\begin{array}{l}\text { Protection } \\
\text { plan }\end{array}$ & $\begin{array}{l}\text { Active site } \\
\text { restitution }\end{array}$ & $\begin{array}{l}\text { Visible } \\
\text { scarring }\end{array}$ \\
\hline WAITAKI & & $\begin{array}{l}\text { Minimal } \\
\text { gardens }\end{array}$ & No & No & $\begin{array}{l}\text { Terracing } \\
\text { and some } \\
\text { trees }\end{array}$ \\
\hline ROXBURGH & & $\begin{array}{l}\text { Gardens at } \\
\text { houses }\end{array}$ & No & No & $\begin{array}{l}\text { Terracing } \\
\text { and trees }\end{array}$ \\
\hline OTEMATATA & & $\begin{array}{l}\text { Gardens at } \\
\text { houses, } \\
\text { trees } \\
\text { around } \\
\text { town }\end{array}$ & No & No & $\begin{array}{l}\text { Location of } \\
\text { sealed } \\
\text { roads, } \\
\text { earthworks, } \\
\text { trees and } \\
\text { gardens } \\
\end{array}$ \\
\hline \multirow[t]{3}{*}{$1 \mathrm{MTT}$} & West Arm & No & Yes & Yes & $\begin{array}{l}\text { Superseded } \\
\text { by } 2 \mathrm{MTT}\end{array}$ \\
\hline & $\begin{array}{l}\text { Deep } \\
\text { Cove }\end{array}$ & No & Yes & Yes & $\begin{array}{l}\text { Earthworks } \\
\text { and tracks }\end{array}$ \\
\hline & Manapouri & $\begin{array}{l}\text { Small } \\
\text { igardens at } \\
\text { houses }\end{array}$ & No & No & Site reused \\
\hline TWIZEL & & $\begin{array}{l}\text { Gardens at } \\
\text { houses, } \\
\text { trees } \\
\text { around } \\
\text { town }\end{array}$ & No & No & Still existing \\
\hline CROMWELL & & $\begin{array}{l}\text { Permanent } \\
\text { gardens }\end{array}$ & $\begin{array}{l}\text { Yes - for } \\
\text { temporary } \\
\text { housing }\end{array}$ & $\begin{array}{l}\text { Yes - for } \\
\text { temporary } \\
\text { housing }\end{array}$ & Permanent \\
\hline 2MTT & West Arm & No & Yes & $\begin{array}{l}\text { Yes, with } \\
\text { inclusion of } \\
\text { DoC }\end{array}$ & $\begin{array}{l}\text { Earthworks, } \\
\text { but mostly } \\
\text { regenerated }\end{array}$ \\
\hline
\end{tabular}

Table 3: Environmental protection assessment of accommodation sites

Planting and gardens: All sites except West Arm and Deep Cove show evidence of plantings by the occupants to the current day. The introduction of new plants into a site can be unpredictable and the existence of introduced species has shown itself hard to eradicate, despite the harshness of the sites.

Protection plan: Protection plans played a very minor role in the planning of construction camps prior to the conservation movement of the 1960s. As a result, actions such as the sealing of roads and pavements, the provision of parking on sites, underground services, inclusion of families into accommodations and fencing all contributed to site damage which is hard to erase. 
Active restitution: Active restitution was a direct result of the introduction of protection plans and was also very minimal prior to the conservation movement of the 1960s. While quantitative data to prove the success of the site restitution at West Arm is not available, the photos in the appendices ${ }^{114}$ show that the site is recovering, but is slower than anticipated by Meridian Energy's plan.

Visible scarring: Every site in the case studies shows some signs of scarring. Where houses, huts and hostels have been removed there are a combination of elements causing visible signs of their previous existence. The photos in the appendices show how significant this damage can be in harsh environments such as Otematata.

Environmental protection and restitution of the accommodation sites was at the will of the MoWD planners until the conservation movement became popularised in the 1960s, coinciding with 1MTT and bringing national attention to infrastructure project sites. Prior to this visible scarring at the accommodation sites was becoming more predominant as inground services, sealed roads and individual house sites (with gardens) became more common. This reached its peak with the permanent damage to the site and introduction of non-native plants en masse at Otematata ${ }^{115}$ still visible where some roads, houses and huts were removed 40 years ago.

Although site preservation increased in importance from this point onwards, it was a slow progression through 1MTT and Twizel until planning consideration was given to the issue at Cromwell and 2MTT.

Cromwell stands as the best example at present of the provision of a planned permanent standard of workers accommodation, having evolved from family housing and the retention petitions of Roxburgh, Otematata and Twizel.

2MTT has been the ultimate expression of singlemens housing to date, incorporating site protection and restitution within a National Park and under national scrutiny.

\footnotetext{
${ }^{114}$ See Appendix $\mathrm{H}$, compare photo $\mathrm{H} 3$ of camp in existence with photos $\mathrm{H} 17-20$ showing regeneration

${ }^{115}$ See Appendix D, photos D5 and 6
} 


\section{DESIGN}

\section{Layout}

The Garden City Movement was founded by Sir Ebenezer Howard in the UK in 1898 , with concise ideas about overall planning of cities, towns and suburbs. The first Garden City was Letchworth, built in 1907, followed by Welwyn in 1920.

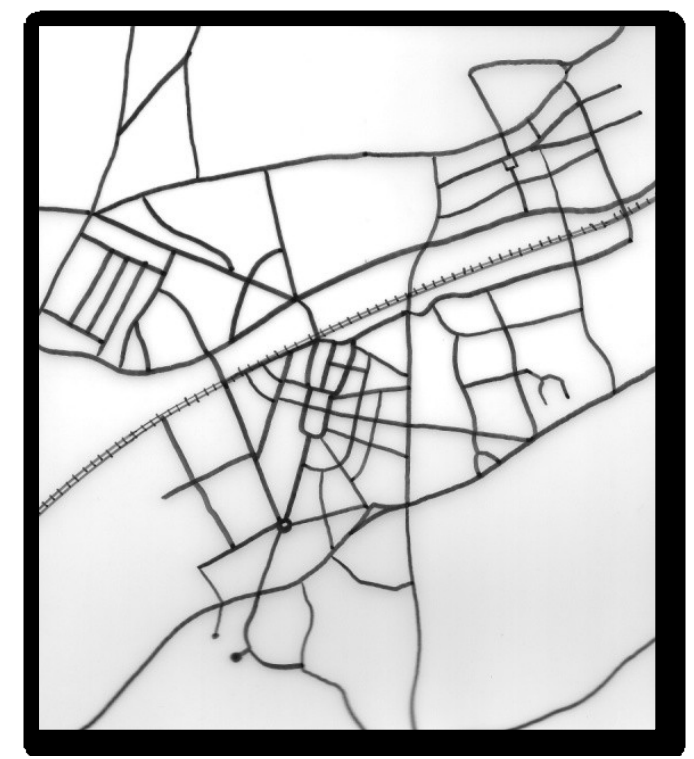

Figure 35: Letchworth, UK

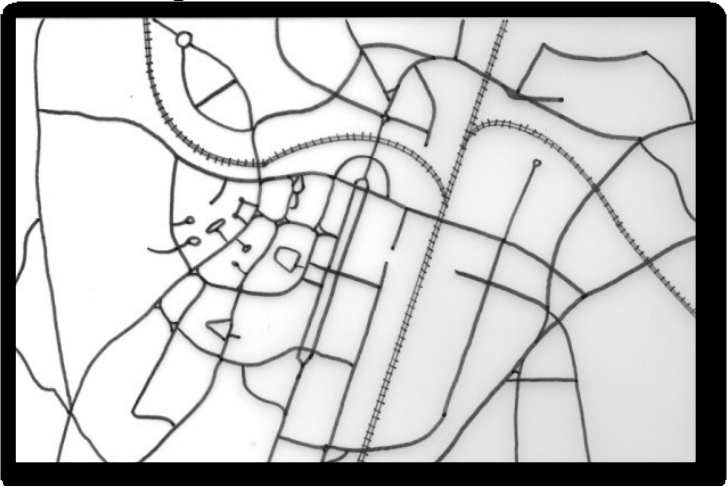

Figure 36: Welwyn, UK

Howard stated "the essential thing is that before a sod is cut, or a brick laid, the town must in its broad outlines be properly planned with an eye to the convenience of the community as a whole, the preservation of natural beauties, the utmost degree of healthfulness and proper regard to communication with the surrounding 
district"116 and, as MacFadyen goes on to show, it was the concept of town planning which became the strongest aspect of the Movement.

The Garden City Movement spread throughout the Commonwealth very rapidly, the NZ Government appointed a town planner "who had been through an architect's office in Letchworth"117.

In the late 1920s the Chairman of the City Housing Corporation of New York began corresponding with Howard. A visit to Letchworth was conducted and full plans of Letchworth were taken back to New York to create an American Garden City in its image ${ }^{118}$ and Radburn was founded in 1929 as a result of this.

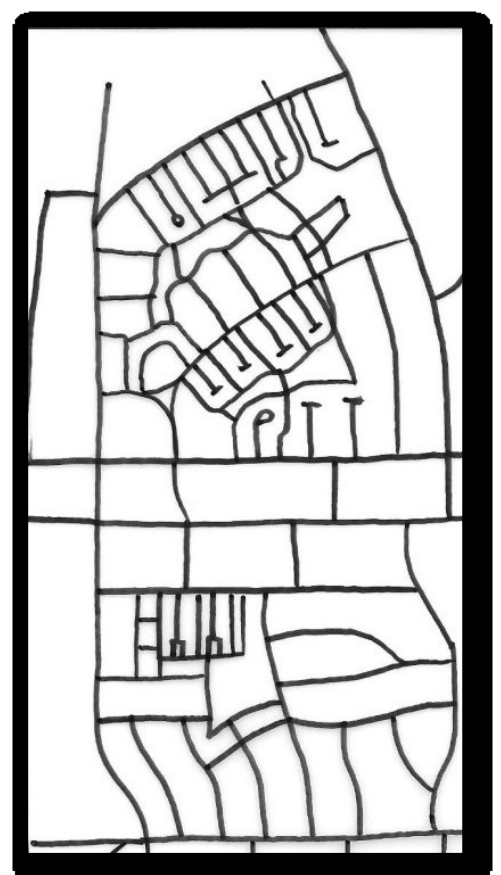

Figure 37: Radburn, NJ, USA

When the Tennessee Valley Authority (TVA) was created in 1933 (as a regional economic development agency to ease the effects of the Depression, including the construction of hydro projects), the opportunity was seen to create a model planned community to promote the TVA. The Garden City model was chosen with the aim of

\footnotetext{
${ }_{116}^{116}$ MacFadyen, p160

${ }^{117}$ Ibid, p163

${ }^{118}$ MacFadyen, p 163
} 
increasing a sense of community ${ }^{119}$. The town of Norris was planned later that year $^{120}$.

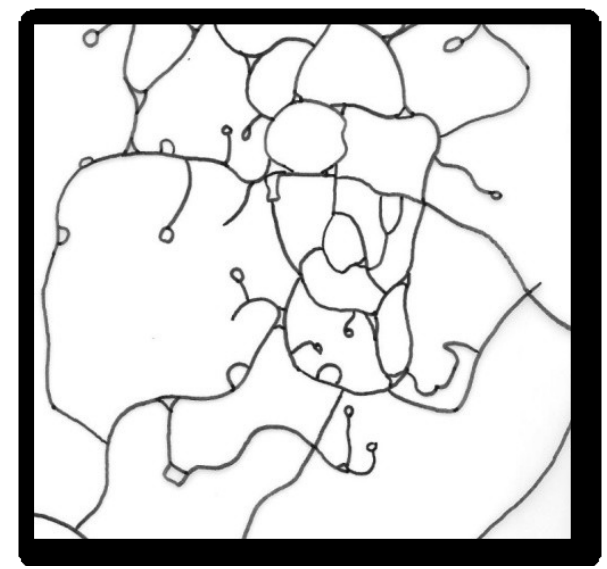

Figure 38:Norris, TN, USA

In NZ, not only was there a town planner trained in the Garden City Movement working in the government departments but there also is evidence that the town planning used by the TVA was influential to the MoWD planners and architects.

The North Island hydrotown of Mangakino was planned in the mid 1940s at a time when Gordon Wilson was taking over as the Chief Architect of the MoWD Division of Housing ${ }^{121}$. Working under Wilson at this time was Frederick Newman. Newman had experience working on workers accommodation in the USSR (1933$37)^{122}$ and both architects were interested in, and had ongoing contact with, the work of the TVA ${ }^{123}$.

Kate Linzey wrote about Mangakino: "in perspective images the landscape is benignly arcadian. As August Sarnitz comments on Plischke's town planning style, he followed the English garden city model inherited from Ebenezer Howard. In this mode, the idealism of the Mangakino project lay not only in its green site, but in the single authority of the client: The Ministry of Works..."124

\footnotetext{
${ }^{119}$ Macy and Bonnemaison, p179

${ }^{120}$ wikipedia

${ }^{121}$ Leach, p 40

122 Ibid, pp 39-40

${ }^{123}$ Ibid, p 115: "There is evidence that Gordon Wilson, Government Architect, kept some contact with the TVA. This is specifically the deposit of a number of non-reproducible articles and official photographs of TVA structures in collection of F H Newman" and p 104: "the Tennessee valley Authority design team acted as a direct model for New Zealand's Hydro Design Office..."

${ }^{124}$ Linzey, p 61
} 
Both of these authors' writings support the argument that Howard's model was the template for the hydro towns in NZ, starting with Mangakino. However, Nick Taylor (et al) contradict this: "the layout of the town [Otematata] was patterned on a Scandinavian design previously used for the North Island hydrotown Mangakino ${ }^{125 " .}$

Whichever the precedent for the layout, there can be no disagreement that Mangakino (planned in 1946) set a new layout pattern for Roxburgh Hydro (planned in 1948) to follow, and that this layout remained a common feature for hydrotowns with family accommodations in the south from Roxburgh through to Cromwell with its multitude of cul-de-sacs, curved streets, green areas and pedestrian walkways.

However, there was a big difference between the layout of the family accommodations and the singlemens accommodations ${ }^{126}$. Despite the Garden City model promoting community cohesion, the singlemen were still located in hostels and huts, separated from the family accommodations throughout the history of the hydrotowns in the south.

Huts were placed in a grid pattern with cookhouses, ablution blocks and hostels breaking the monotony of the layout ${ }^{127}$.

At Cromwell this began to change with the Joint Planning Committee recommending that: "The singlemens' camps will be residential uses and, as such, should be located within or adjacent to the residential areas rather than in a position remote from the remainder of the town. This means that the singlemens' camps will conform with the design requirements outlined in this report and should be subject to satisfactory siting and landscaping ${ }^{128 "}$. However, the full measure of this recommendation did not make it through to realisation.

Layout, therefore, has a split history dependant on the inclusion of families and the future of the planning of the layout of construction camps will remain heavily weighted by this issue.

\footnotetext{
${ }^{125}$ Taylor et al, "A Case Study of Twizel", p 5

${ }^{126}$ See appendix D, photo D4 for an illustration of this

${ }_{127}^{127}$ See Appendix F, photo F5 for an illustration of this at top

128 Joint Planning Committee, p 15
} 


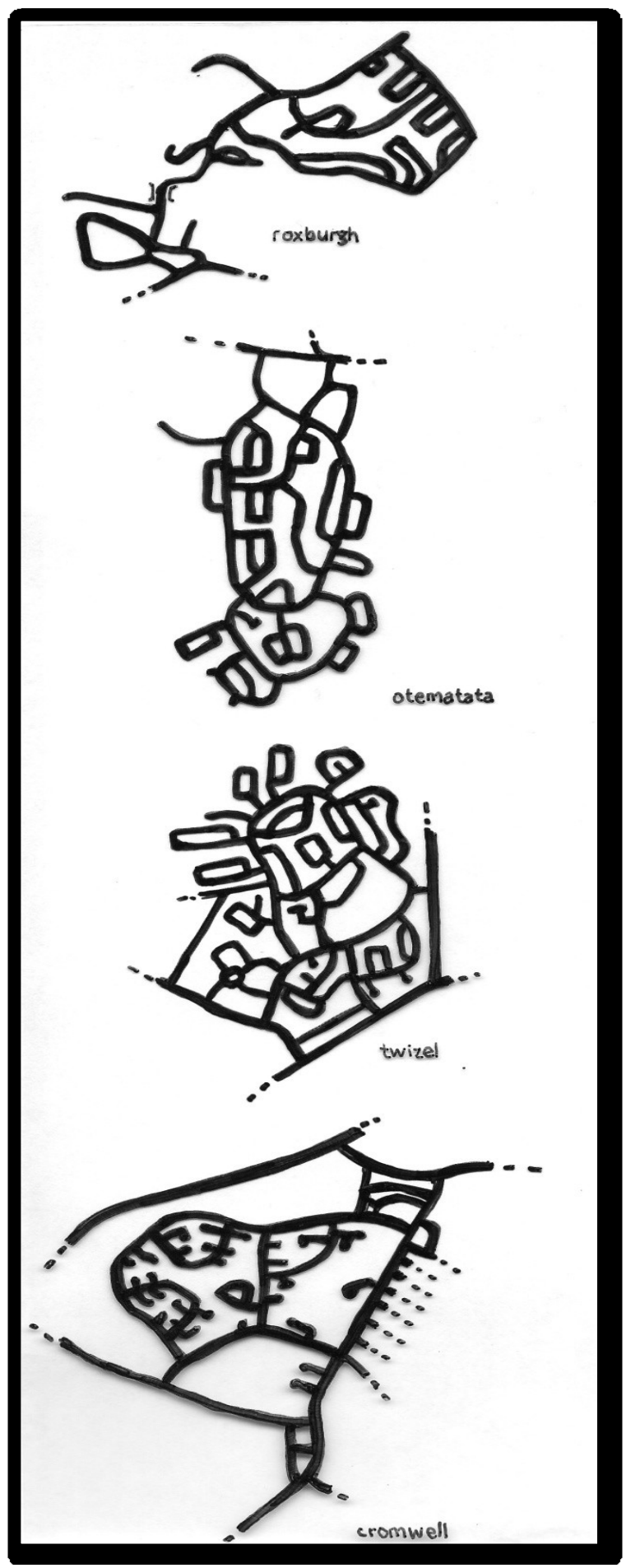

Figure 39: comparative layouts 


\begin{tabular}{|c|c|c|c|c|c|}
\hline & & $\begin{array}{l}\text { Integration of } \\
\text { Married and } \\
\text { Singles }\end{array}$ & $\begin{array}{l}\text { Safe } \\
\text { access }\end{array}$ & Fire separation & $\begin{array}{l}\text { Visual } \\
\text { separation }\end{array}$ \\
\hline WAITAKI & & No & Track & No & No \\
\hline ROXBURGH & & No & Road & No & No \\
\hline OTEMATATA & & No & Road & $\begin{array}{l}\text { Huts - no } \\
\text { Houses - yes }\end{array}$ & $\begin{array}{l}\text { Minimal, by } \\
\text { greater distance } \\
\text { between houses }\end{array}$ \\
\hline \multirow[t]{3}{*}{ 1MTT } & West Arm & No (singles only) & Boat & No & No- \\
\hline & $\begin{array}{l}\text { Deep } \\
\text { Cove }\end{array}$ & No (singles only) & Boat & No & No- \\
\hline & Manapouri & $\begin{array}{l}\text { No (married } \\
\text { only) }\end{array}$ & Road & Yes & No \\
\hline TWIZEL & & No & Road & $\begin{array}{l}\text { Huts - no } \\
\text { Houses - yes }\end{array}$ & $\begin{array}{l}\text { Some from } \\
\text { garages and } \\
\text { plantings }\end{array}$ \\
\hline CROMWELL & & $\begin{array}{l}\text { Some rental and } \\
\text { boarding with } \\
\text { local community }\end{array}$ & Road & $\begin{array}{l}\text { Permanent } \\
\text { houses to state } \\
\text { housing } \\
\text { standards }\end{array}$ & $\begin{array}{l}\text { Yes, from } \\
\text { garages, fences } \\
\text { and plantings }\end{array}$ \\
\hline 2MTT & West Arm & No (singles only) & Boat & $\begin{array}{l}\text { Sprinklers, fire } \\
\text { doors, etc, to } \\
\text { NZBC }\end{array}$ & $\begin{array}{l}\text { Some from } \\
\text { offset of } \\
\text { modules- }\end{array}$ \\
\hline
\end{tabular}

Table 4: Layout assessment of accommodation sites

Integration: Throughout the history of hydro housing studied in this thesis, married and singlemens accommodations have been segregated. The MoWD had a strong policy of not allowing singlemen to board or flat in the married wage workers or staff housing, which was mostly followed by private enterprise consortiums as well. This furthered social separations.

Safe access: The provision of safe access to the accommodations was affected by two major influences:

1. The amount of private transport ownership of the residents

2. The inclusion of families

As private vehicle ownership became more common, sealed road access to all accommodations became more important. In the case of 1MTT and 2MTT camps at Deep Cove and West Arm, the lack of housing for families meant that many of the men relied on safe transport options to leave camp on days off to visit their families.

Fire separation: Although this has become a major concern in building standards, it was of minimal importance in the huts and hostels in the case studies prior to Cromwell. In the early camps (ironically constructed of the most flammable 
materials), close proximity of huts and houses assisted in protection from the climate and this was weighted more heavily in the camp planning than fire risk. As houses began to be allocated individual sites the proximity of houses shifted to a safer distance (from the point of fire risk) but huts were often added on boundaries, thus reducing the effectiveness of this.

Visual separation: Visual separation was non-existent in the huts and hostels throughout the case studies. Although the number of windows in huts was minimal in early camps and the hostel modules were offset at 2MTT, shared ablutions were standard in all camps, reducing privacy. The houses fared somewhat better, with privacy increasing in value and introduced in the planning stage once houses began to be allocated individual sites.

The adoption of an evolved form of Ebenezer Howard's model coincided with the inclusion of family housing at Roxburgh, along with improved access and decreased site risks as the accommodation sites moved further from the project sites.

Despite the social cohesion intentions of the Howard model, segregation of singlemens and married accommodations formed an integral part of the layout of all of the hydrotowns.

Both fire separation and visual separation increased only in the family housing, carrying very little weight in the singlemens accommodation until the introduction of NZBC standards. 
b) Bedroom or bedrooms according to the standards of number and space set out in the Second Schedule hereto

c) Bathroom

d) Water-closet pan either in bathroom, in lavatory, or in separate closet

2. For a boardinghouse or lodginghouse there must be adequate dining-room and living-room space in addition to kitchen, and sanitary accommodation must be provided in the proportion of one bathroom and one water-closet for every ten persons and one lavatory basin for every seven persons

B. Number of persons in the care of children shall be computed as in clause 2 of the Second Schedule

C. In each of the cases set out above living-rooms and bedrooms shall be included only if belonging exclusively to the dwelling unit, and bathroom and water-

closet pan shall be included only -

a) If belonging exclusively to the dwelling unit; or

b) If shared, then if used by not more than seven persons" 130

The Depression (from 1929 until WWII) exacerbated the results of the survey and the need for state housing was obvious (secondary to which was an acknowledged need to create jobs). As a result, the Department of Housing Construction set about investigating the best designs and materials for the new state housing. The following are some of the conclusions reached by 1937 :

"Individuality of design was of the utmost importance.....Women's desires in regards to housing are just as varied as men's, and instead of attempting to impose uniformity upon all the women of New Zealand it is the Department's desire to accord to them a measure of individual selection, to get at the commencement a variety of types rather than one type"

"Dwellings are sited at distances varying from $20 \mathrm{ft}$ to $60 \mathrm{ft}$ from the front boundary. On flat ground they are staggered in saw-tooth fashion, symmetrically set back, or grouped about some central feature"

"The minimum width between house and side boundary is not less than $5 \mathrm{ft}$ on one side and $9 \mathrm{ft}$ on the other, the latter width being great enough to allow cars to be garaged at the back of the house. When required, detached garages are provided, but there is an increasing tendency to provide communal garages in groups of six or so to serve the needs of the surrounding houses. Dwellings are planned and arranged on the site, so that the most is made of any view that may be obtained, and are placed to expose the side to the sun as much as possible. Living-rooms are given the choice aspect - the maximum sun and view. A view of the street from the living-room is considered an advantage. Living-rooms are arranged to avoid overlooking adjoining porches and windows. Generally bedrooms will receive the morning sun and kitchens the morning and afternoon

130 ibid, pp 19-20 
sun. Great care is exercised to ensure that front and back porches are sheltered from prevailing winds, which, with few exceptions, are from the south-east and south-west over the whole of New Zealand.

The average area of detached houses is approximately 1,000 sq ft. The bedsitting room type of flat, the smallest unit erected, is not less than 400 square feet. Living-rooms have an average area of approximately 180 square feet and bedrooms 130 square feet"

"Some houses may have a dining-room; others may have a meals' recess off living-room or kitchen. As a rule the kitchen is not regarded as an eating-place but as a workroom, and is fully equipped with cupboards, bins, drawers, safe, drying cupboard, terrazzo sink-top, and electric or gas range; space is frequently provided for a work-table. An electric or gas hot-water service is installed. Open fireplaces are provided in living-rooms. Each dwelling has a separate coat cupboard and linen cupboard, and all bedrooms have a built-in wardrobe. All baths are built-in, and each bathroom is fitted with a shaving cabinet and mirror. Separate laundries are provided to detached and semi-detached houses. In detached houses the WC is located in a separate cubicle......Power-points are installed in living-rooms, kitchens and most bedrooms. A wireless aerial is provided in the roof space and carried to a connection in the living-room"

"Front gardens have been treated on broad lines by eliminating dividing fences. A trellis fence is built between the houses, and a post-and-wire or board-and-batten fence is carried round to the rear of the trellis, thus providing a secluded and safe playing-space for children. In most districts the sections have already been planted with trees and hedges, which in the later years will add materially to the amenities of the developments"

"Repetition of similar or almost similar plans used in prefabrication work will result in a considerable degree of monotony which can be partially obviated by careful siting, attention to colour schemes and planting" 131

So, in the late 1930s the NZ Government set up the Department of Housing Construction and was heavily investing in a process to upgrade the standard of accommodation in NZ. They had conducted a survey of existing accommodation and mapped out all accommodation which was below the standard set by them and then proceeded to write policy to guide the design and construction of a state housing scheme, the standards for which were higher than the minimum standard of dwelling.

The Department of Housing Construction was also drawing distinctions between state housing and "workers' dwellings" ${ }^{132}$ at the same time, particularly in their

${ }^{131}$ ibid, pp27-46 
recognition of the importance of individuality, leaving the Department of Housing Construction to create state housing, while its parent body, the MoWD, designed and constructed a separate style of housing for workers on large state run projects, which was not subject to the same standards.

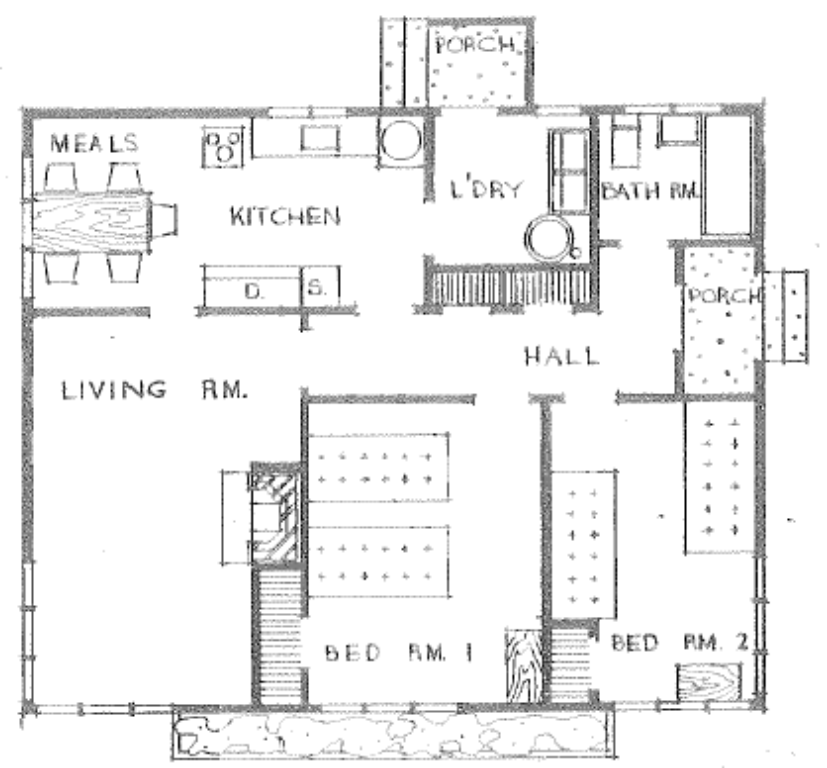

Figure 40: Typical two bedroom state house plan, 1949

Figure 40: Typical two bedroom state house
(illustration from Firth p32)

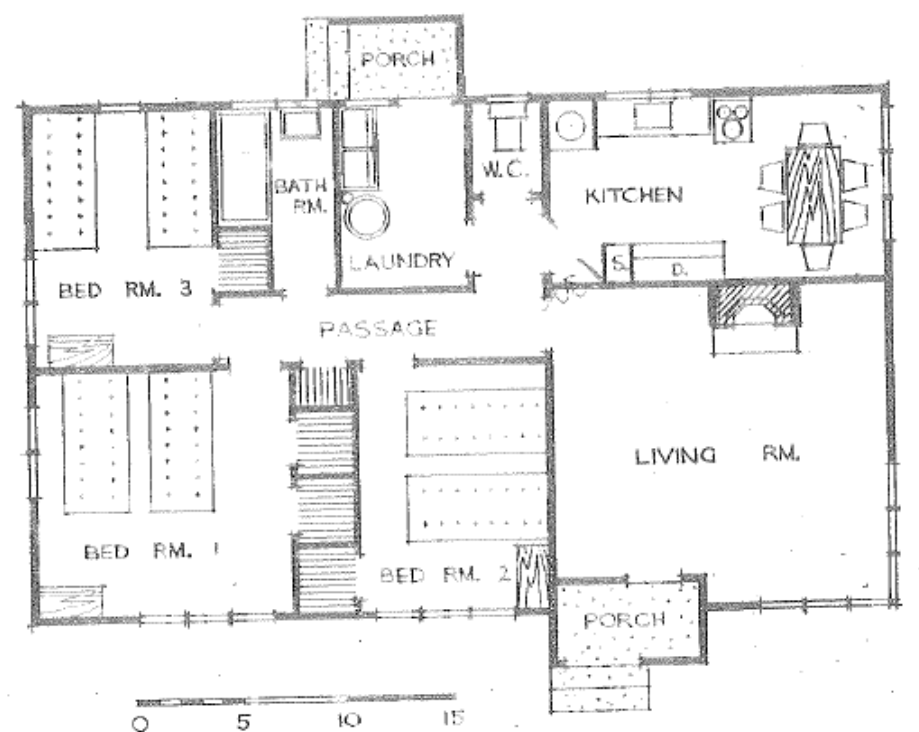

Figure 41: Typical three bedroom state house plan (without hall), 1949 (illustration from Firth p34)

${ }^{132}$ Department of Housing Construction, State Housing, p 6 
The houses went through a range of design changes at each location. This meant that houses which were transported between camps also underwent changes between camps, often being altered to meet new design requirements.

Waitaki (1928-35) was the first hydro camp in the region to offer timber houses. Prior to this the houses had been tents, with only one or two rooms. At Waitaki timber houses were introduced for staff. Junior married staff were allocated two bedroom houses measuring $6.5 \mathrm{~m} \times 5.25 \mathrm{~m}(370 \mathrm{sq} \mathrm{ft})$ and senior staff were allocated permanent houses constructed from concrete blocks (which existed until now as accommodation for electrical company workers at the hydro plant, but are currently undergoing alterations to be transformed into visitor accommodation).

Each house was also allocated an area for an outdoor toilet, with workers required to dig their own pits.

Wage workers, however, were not eligible for houses and married wage workers were allocated two huts to fashion their own homes out of.

In contrast, the next large hydro camp in the region, at Roxburgh (1949-56), introduced a sewerage system, water and electricity to all houses - the first to do so. This was also the first camp to allocate houses to married wage workers.

Married wage workers were allocated 48sq.m. (520 sq ft) houses with two bedrooms, a living room, kitchen, laundry, bathroom and a separate (indoor) toilet. Workers with large families were given extra singlemens huts to join to their houses as they saw fit.

MoWD junior staff were allocated three bedroom houses of 76sq.m. (more than double the size of the houses that they were allocated at Waitaki) and senior staff were allocated 93sq.m. (1000 sq ft) houses.

The interior of all houses were left bare for the occupants to decorate and the occupants were also free to make alterations as they saw fit. This was later to affect the transportability of these buildings which had been designed as the first truly transportable houses in the hydro camps. Also affecting the transportability of the houses were the brick chimneys which had been installed by the MoWD. 
Despite the fact that the houses at Roxburgh were "not built to last more than ten or fifteen years ${ }^{133 "}$ the majority of these houses were transported to Otematata (195771) and altered there to fit the new design prescribed by the MoWD under the new housing regulation for the project. Again the house sizes were allocated according to position, with the floor areas staying the same as those at Roxburgh. This meant that huts were again allocated to the larger families to add to their houses as they wished.

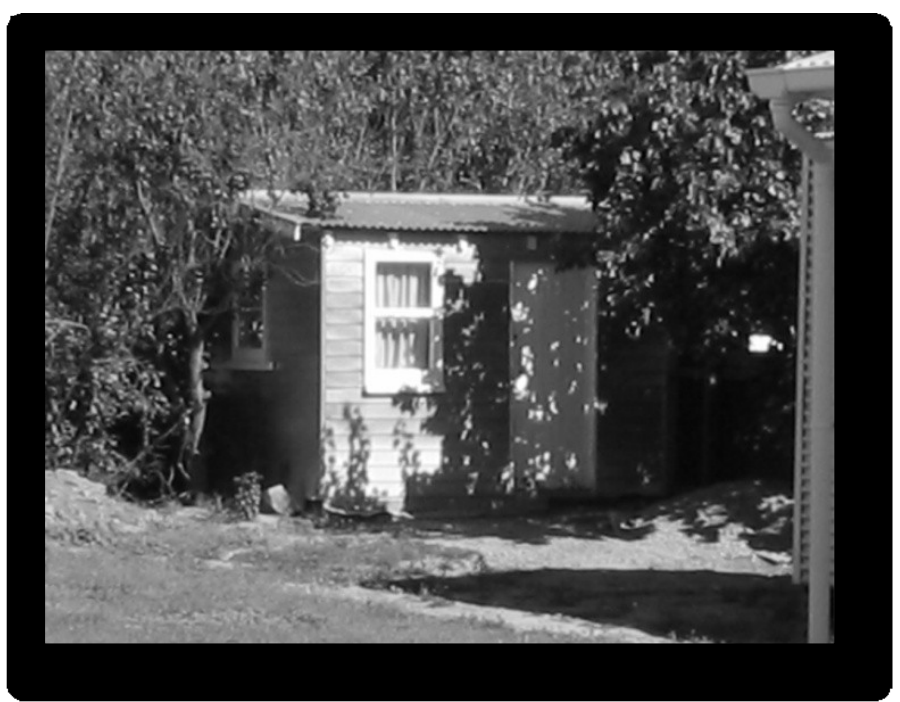

Figure 42: A singlemens' hut placed next to a house for additional accommodation, Otematata, 2005

The main changes at Otematata were in materials, predecoration of interiors and the allocation of gardens. With cars becoming more popular, space was required in the housing areas for parking. This growth of external space combined with full services to the houses, the new allocation of gardens and the T shape of the houses to allow more privacy in and around the houses (and the new materials required less shelter from the elements by close proximity of other buildings). The MoWD installed electric heating instead of solid fuel heaters as they had learnt that the chimneys were affecting transportability and they were already planning ahead to transport these houses post-project.

The occupants were comfortable here and set about altering their houses to make them into homes, culminating in a petition to retain some of the township when the dams were completed. It is worth noting that half of this town still exists.

${ }^{133}$ Campbell, p6 


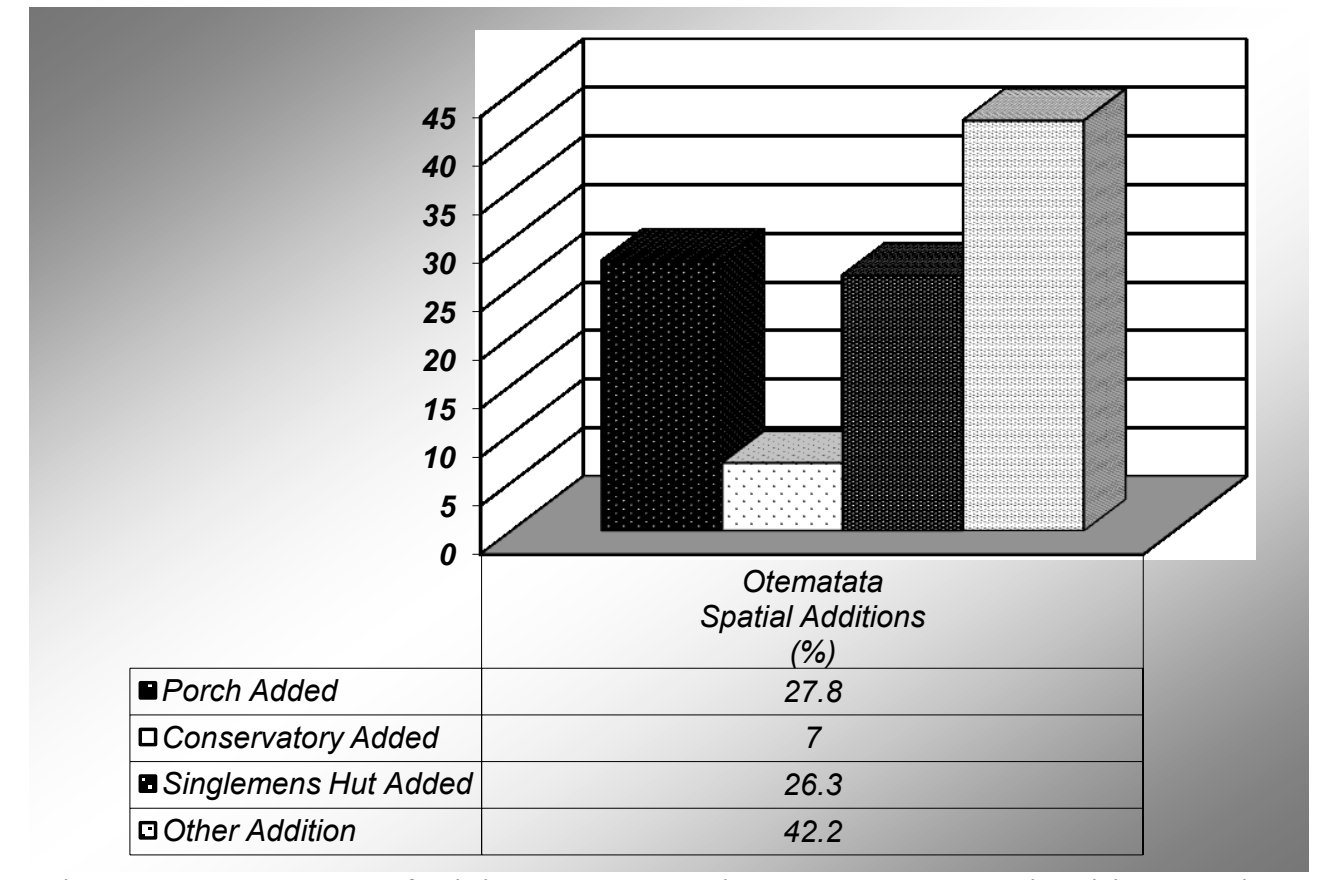

Figure 43: Percentage of original hydro dwellings at Otematata with visible spatial additions, 2005

In 1968 half of the Otematata houses were altered in the workshops at Otematata to meet the standards at the new hydro camp at Twizel (1968-84). This camp was to be the first in the region to allocate housing according to the size of the family as well as to their position with the MoWD. In reaction to the retention of part of Otematata (and thus the rejection of the "temporary housing" label) and the increased length of the hydro projects, the government was attempting to bring housing standards to bear on the MoWD camps in alignment with those of permanent state housing. Partially this was due to strong demands by the workers and their families through various workers' organisations ${ }^{134}$.

The housing at Twizel was designed to be temporary, as at previous hydro towns in the region. A desire for more privacy of the occupants can be seen in the layout of this housing and the floor plans (below) show a much greater regard for differentiation between public and private space, with covered entrances, porches and hallways introduced into the designs.

${ }^{134}$ Sheridan, p91 


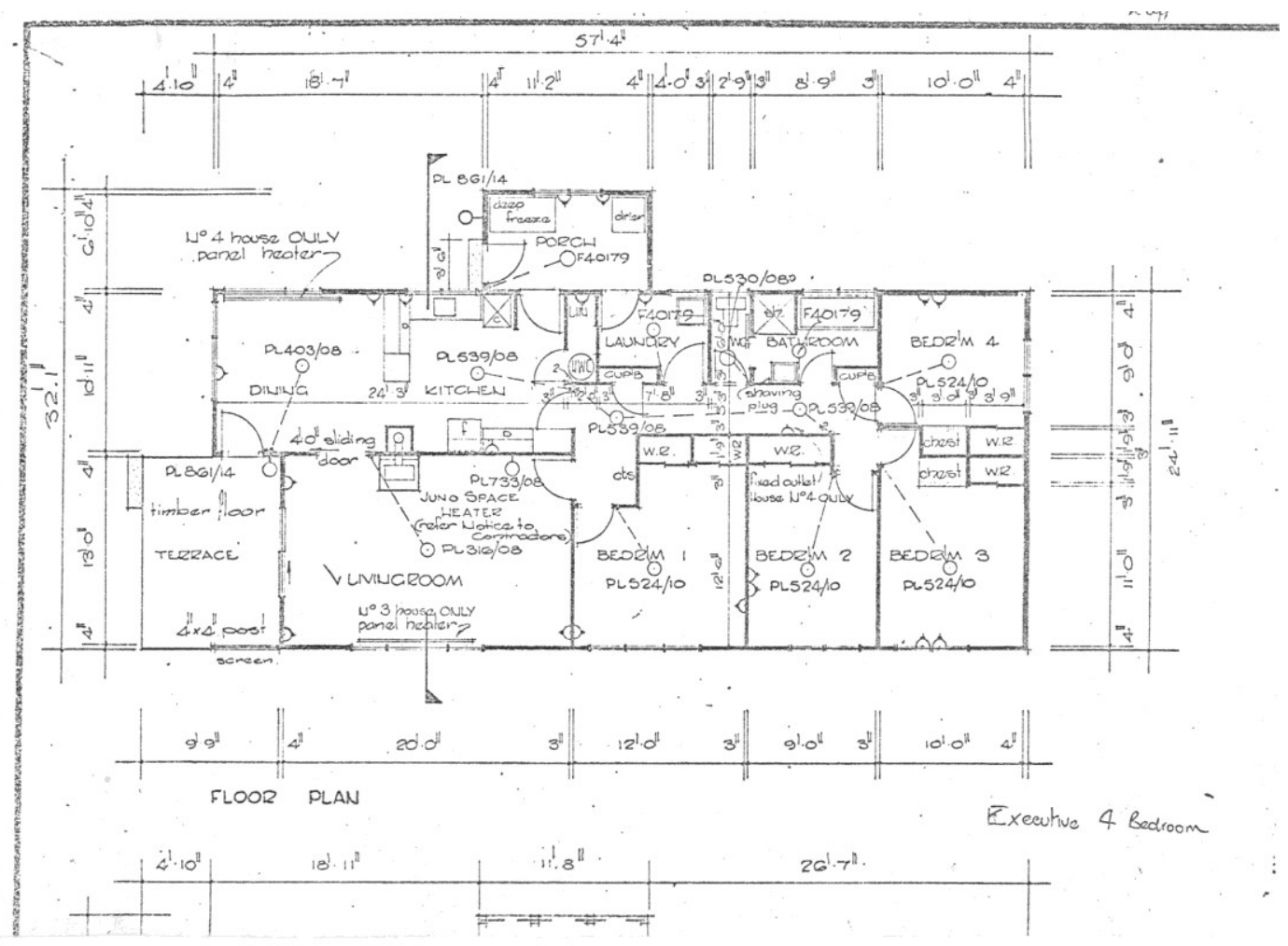

Figure 44: Executive four bedroom house plan, Twizel

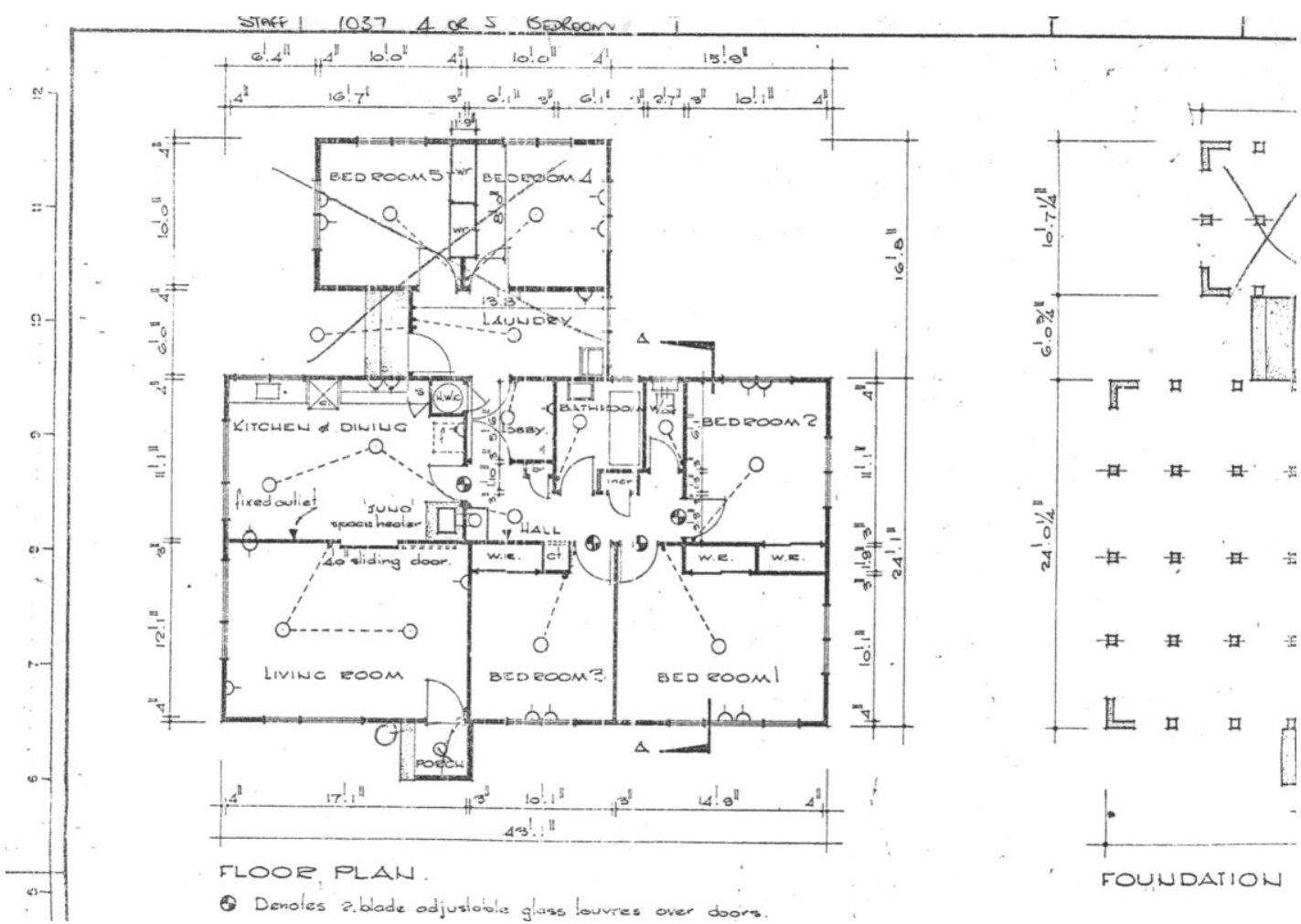

Figure 45: Five bedroom staff house plan, Twizel 


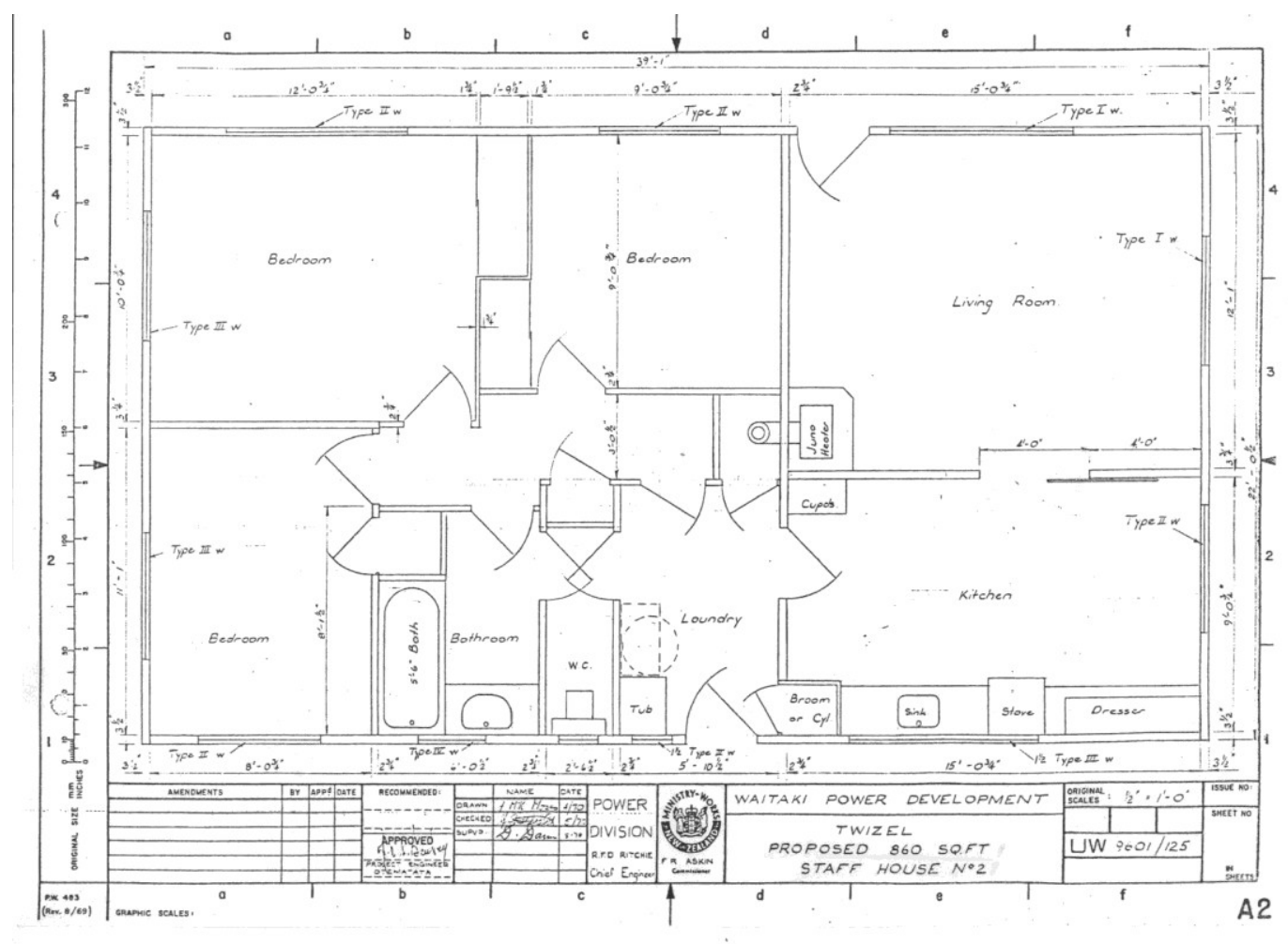

Figure 46: Three bedroom staff house plan, Twizel

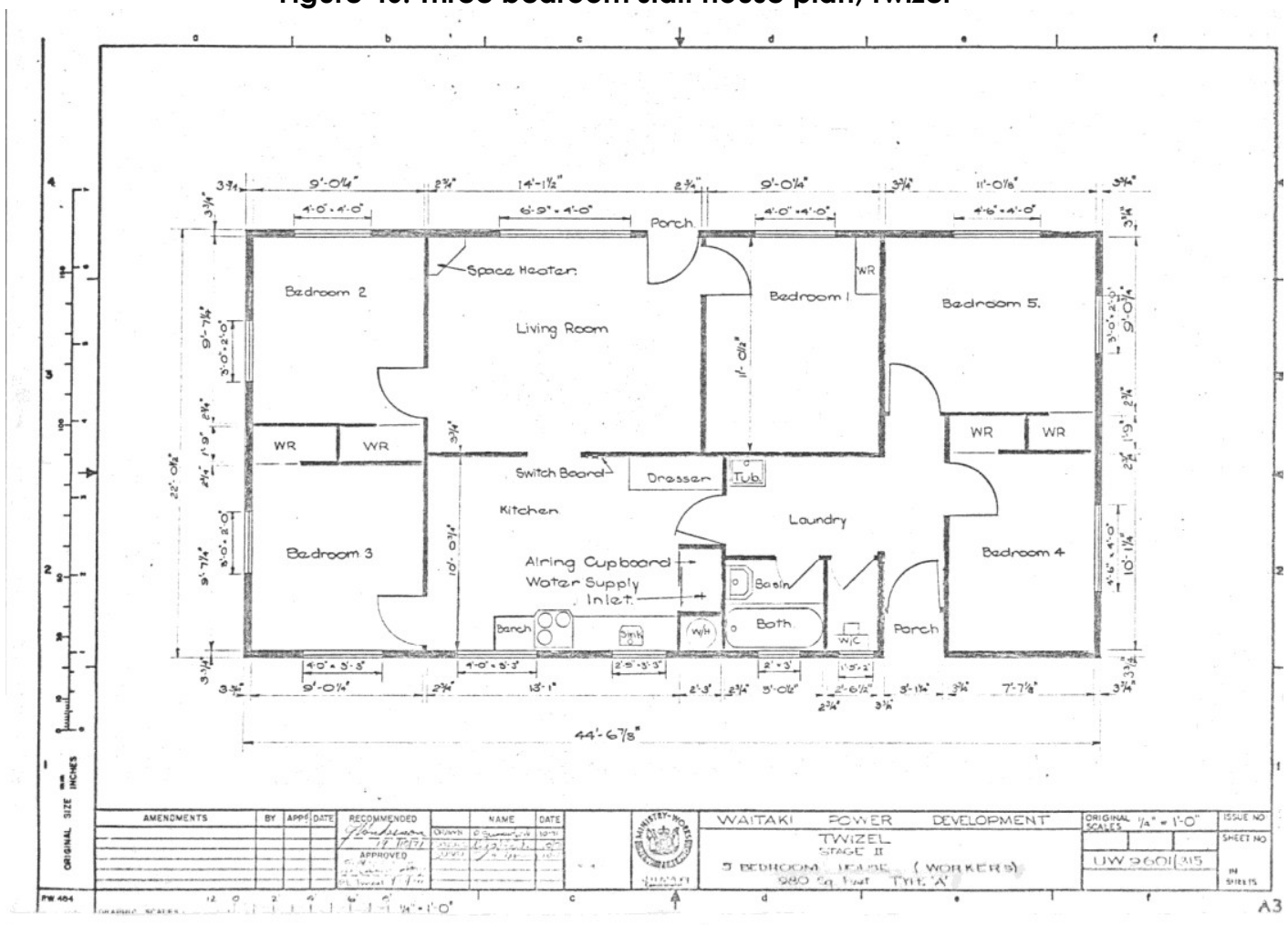

Figure 47: Five bedroom wage workers' house plan, Twizel 


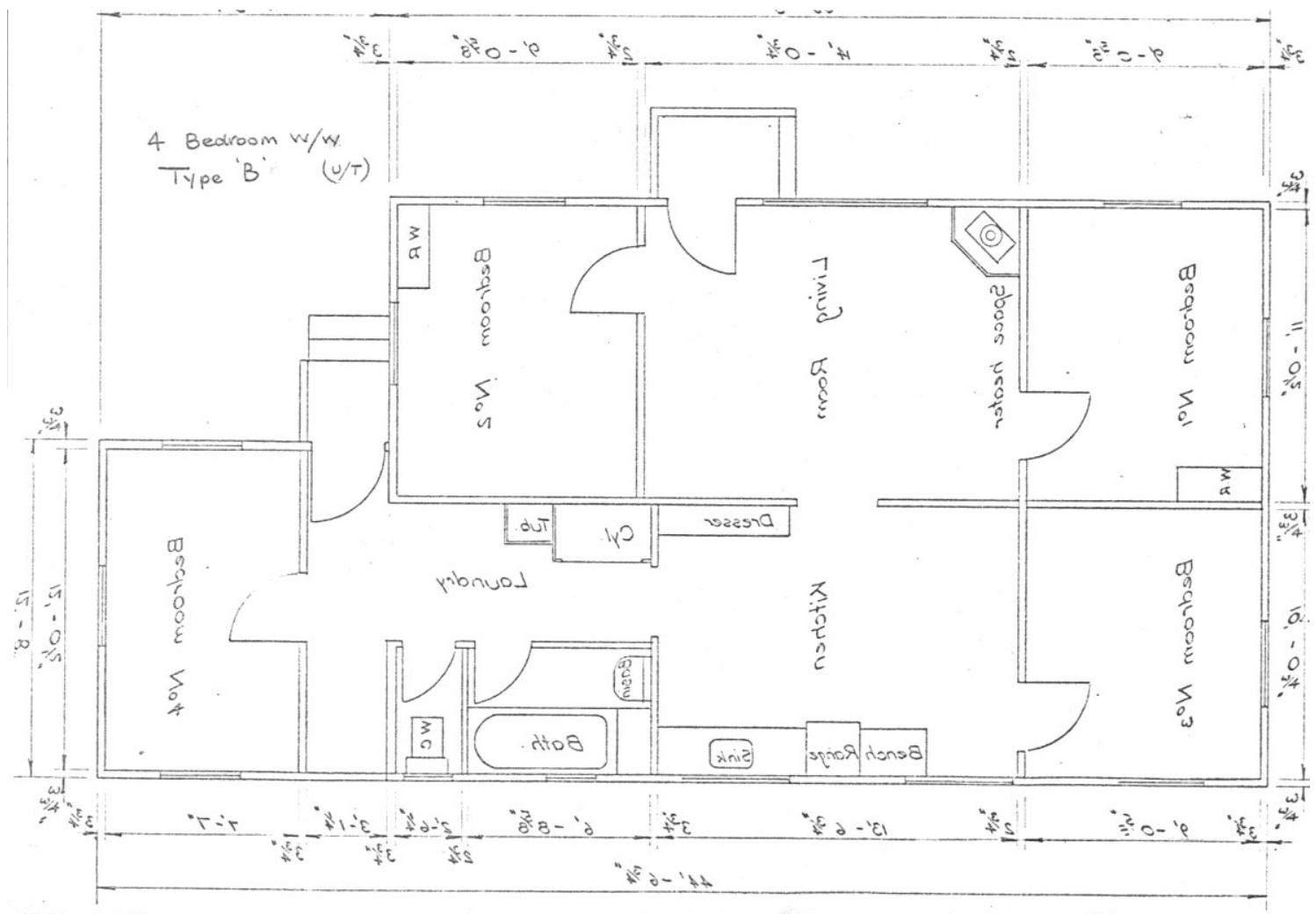

Figure 48: Four bedroom wage workers' house plan, Twizel

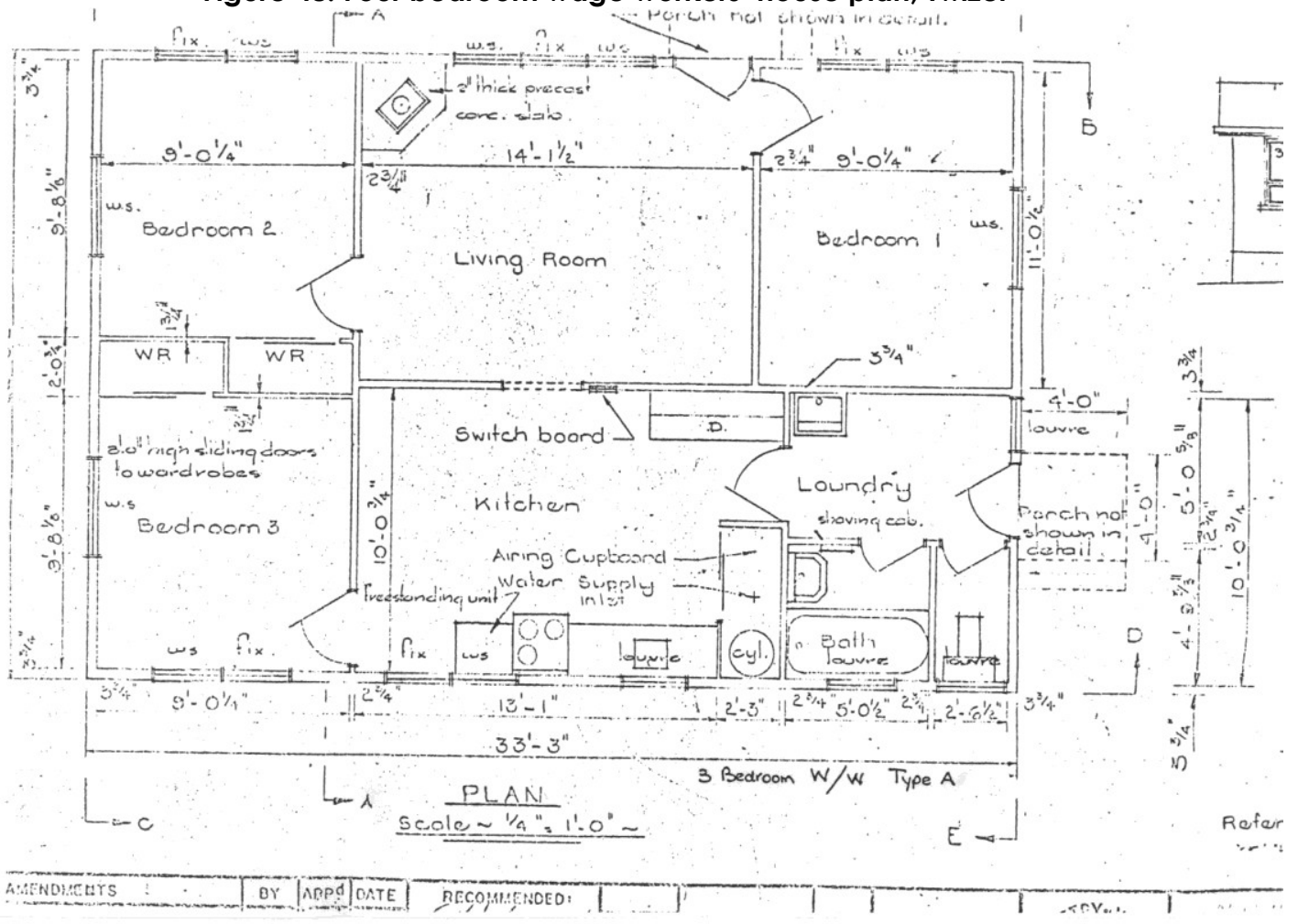

Figure 49: Three bedroom wage workers' house plan- type A, Twizel 


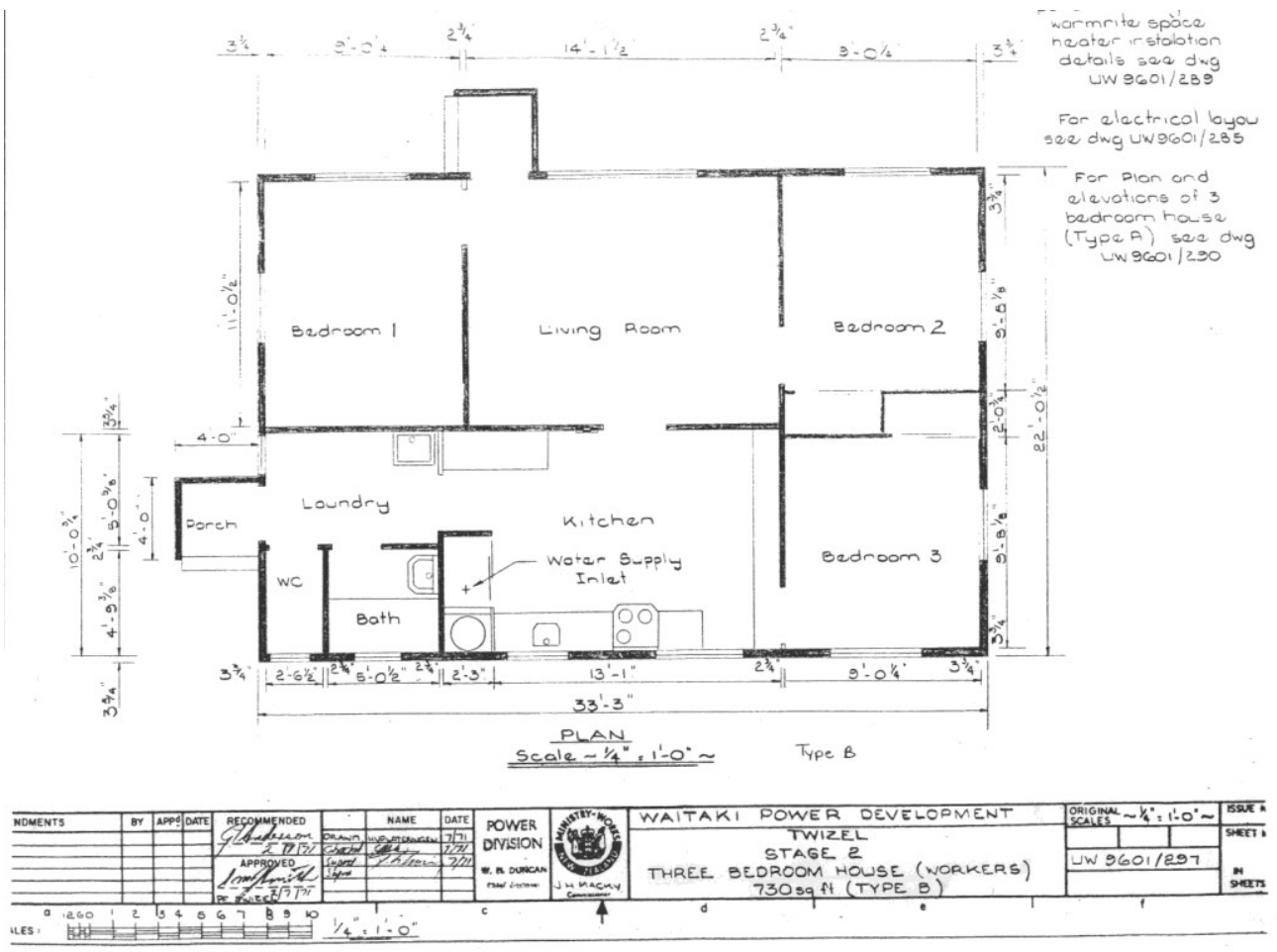

Figure 50: Three bedroom wage workers' house plan- type B, Twizel (Plans courtesy of Mackenzie District Council)

In a revision of previous policy, additions were made to these houses where needed in lieu of adding huts.

Garages and plants were allocated to each house site and fit out items were upgraded drastically for the houses, including the addition of showers and hot water heaters. Again there was also a massive upgrade in materials used in the construction of these houses.

Although publicly announced as a temporary town, design changes made in 1970 (at the same time as Otematata was entering negotiations for partial retention with local authorities) such as solid-fuel burners and large waterheaters suggest that the MoWD was already relinquishing the idea of transportability.

Just over 30 years after the government set standards for state housing these standards were finally matched in hydro town housing in the region in the form of executive and some staff housing at Twizel.

The history of the housing in camps combined with the commercial nature of the venture (private enterprise project) and government housing standards (Housing Corporation built the permanent houses) led to permanent housing being provided at 
Cromwell, with an intention from the start of the project for the housing to be sold at completion of the project. This led to a vast contrast with the housing in the previous camps, the most obvious of which is the great array of varying house designs. 


\begin{tabular}{|c|c|c|c|c|c|c|c|c|c|c|c|c|}
\hline & YEAR & $\begin{array}{l}\text { AREA } \\
\text { (sq ft) }\end{array}$ & $\begin{array}{c}\text { BEDROOMS } \\
\text { (\#) }\end{array}$ & $\begin{array}{c}\text { MASTER } \\
\text { BEDROOM } \\
\text { (sq ft) }\end{array}$ & $\begin{array}{l}\text { WATER } \\
\text { (type) }\end{array}$ & $\begin{array}{l}\text { STOVE } \\
\text { (type) }\end{array}$ & $\begin{array}{l}\text { PORCH } \\
(\#)\end{array}$ & $\begin{array}{l}\text { ROOF } \\
\text { (type) }\end{array}$ & $\begin{array}{l}\text { BATHROOM } \\
\text { (type) }\end{array}$ & $\begin{array}{c}\text { INSULATION } \\
\text { (yes/no) }\end{array}$ & $\begin{array}{c}\text { STORAGE } \\
\text { (yes/no) }\end{array}$ & $\begin{array}{l}\text { GARAGE } \\
\text { (yes/no) }\end{array}$ \\
\hline $\begin{array}{c}\text { STATE } \\
\text { HOUSING }\end{array}$ & 1938 & 1000 & 3 & 130 & $\begin{array}{c}\text { Electric/ } \\
\text { gas HWC }\end{array}$ & Electric/gas & 2 & $\begin{array}{l}\text { Corrugated } \\
\text { iron }\end{array}$ & $\begin{array}{c}\text { Bath, separate } \\
\text { toilet }\end{array}$ & Yes & Yes + BIW & Yes \\
\hline \multicolumn{13}{|l|}{ WAITAKI } \\
\hline $\begin{array}{c}\text { Junior } \\
\text { married staff }\end{array}$ & $\begin{array}{c}1928- \\
35\end{array}$ & 370 & 2 & & $\begin{array}{l}\text { Cold tap } \\
\text { outside }\end{array}$ & Solid fuel & 0 & Malthoid & none & No & No & No \\
\hline $\begin{array}{c}\text { Senior } \\
\text { married staff }\end{array}$ & $\begin{array}{c}1928- \\
35\end{array}$ & & & & $\begin{array}{l}\text { Cold tap } \\
\text { outside }\end{array}$ & Solid fuel & 0 & $\begin{array}{l}\text { Corrugated } \\
\text { iron }\end{array}$ & $\begin{array}{l}\text { Toilet outside, } \\
\text { bath inside }\end{array}$ & No & No & No \\
\hline $\begin{array}{c}\text { Married wage } \\
\text { workers }\end{array}$ & $\begin{array}{c}1928- \\
35\end{array}$ & 160 & 1 & 80 & $\begin{array}{l}\text { Cold tap } \\
\text { outside }\end{array}$ & Solid fuel & 0 & Malthoid & none & No & No & No \\
\hline \multicolumn{13}{|l|}{ ROXBURGH } \\
\hline $\begin{array}{c}\text { Junior } \\
\text { married staff }\end{array}$ & $\begin{array}{c}1949- \\
56\end{array}$ & 820 & 3 & & $\begin{array}{c}\text { Indoor } \\
\text { plumbing }\end{array}$ & Solid fuel & 0 & Malthoid & $\begin{array}{c}\text { Bath in } \\
\text { laundry, } \\
\text { separate toilet }\end{array}$ & No & No & No \\
\hline $\begin{array}{c}\text { Senior } \\
\text { married staff }\end{array}$ & $\begin{array}{c}1949- \\
56\end{array}$ & 1000 & 3 & & $\begin{array}{c}\text { Indoor } \\
\text { plumbing }\end{array}$ & Solid fuel & 0 & Malthoid & $\begin{array}{c}\text { Bath in } \\
\text { laundry, } \\
\text { separate toilet }\end{array}$ & No & No & No \\
\hline $\begin{array}{l}\text { Married wage } \\
\text { workers }\end{array}$ & $\begin{array}{l}1949- \\
56\end{array}$ & 520 & 2 & & $\begin{array}{c}\text { Indoor } \\
\text { plumbing }\end{array}$ & Solid fuel & 0 & Malthoid & $\begin{array}{l}\text { Bath in } \\
\text { laundry, } \\
\text { separate toilet }\end{array}$ & No & No & No \\
\hline \multicolumn{13}{|l|}{ OTEMATATA } \\
\hline $\begin{array}{c}\text { Junior } \\
\text { married staff }\end{array}$ & $\begin{array}{c}1957- \\
71\end{array}$ & 820 & 3 & & $\begin{array}{l}\text { Electric } \\
\text { HWC }\end{array}$ & Electric & 0 & $\begin{array}{c}\text { Corrugated } \\
\text { iron }\end{array}$ & $\begin{array}{c}\text { Bath, separate } \\
\text { toilet }\end{array}$ & No & No & No \\
\hline $\begin{array}{c}\text { Senior } \\
\text { married staff }\end{array}$ & $\begin{array}{c}1957- \\
71\end{array}$ & 1000 & 3 & & $\begin{array}{l}\text { Electric } \\
\text { HWC }\end{array}$ & Electric & 0 & $\begin{array}{c}\text { Corrugated } \\
\text { iron }\end{array}$ & $\begin{array}{c}\text { Bath, separate } \\
\text { toilet }\end{array}$ & No & No & No \\
\hline $\begin{array}{c}\text { Married wage } \\
\text { workers }\end{array}$ & $\begin{array}{c}1957- \\
71\end{array}$ & 520 & 2 & & $\begin{array}{l}\text { Electric } \\
\text { HWC }\end{array}$ & Electric & 0 & $\begin{array}{c}\text { Corrugated } \\
\text { iron }\end{array}$ & $\begin{array}{c}\text { Bath, separate } \\
\text { toilet }\end{array}$ & No & No & No \\
\hline \multicolumn{13}{|l|}{ TWIZEL } \\
\hline $\begin{array}{l}3 \text { bedroom } \\
\text { staff }\end{array}$ & $\begin{array}{c}1969- \\
84\end{array}$ & 830 & 3 & 120 & $\begin{array}{l}\text { Electric } \\
\text { HWC }\end{array}$ & $\begin{array}{c}\text { Electric + } \\
\text { solid fuel } \\
\text { heater }\end{array}$ & 0 & $\begin{array}{l}\text { Corrugated } \\
\text { iron }\end{array}$ & $\begin{array}{c}\text { Bath, separate } \\
\text { toilet }\end{array}$ & Yes & BIW & Yes \\
\hline $\begin{array}{c}5 \text { bedroom } \\
\text { staff }\end{array}$ & $\begin{array}{c}1969- \\
84\end{array}$ & 1300 & 5 & 140 & $\begin{array}{l}\text { Electric } \\
\text { HWC }\end{array}$ & $\begin{array}{c}\text { Electric + } \\
\text { solid fuel } \\
\text { heater }\end{array}$ & 2 & $\begin{array}{l}\text { Corrugated } \\
\text { iron }\end{array}$ & $\begin{array}{c}\text { Bath, separate } \\
\text { toilet }\end{array}$ & Yes & BIW & Yes \\
\hline $\begin{array}{l}4 \text { bedroom } \\
\text { executive }\end{array}$ & $\begin{array}{c}1969- \\
84\end{array}$ & 1450 & 4 & 140 & $\begin{array}{l}\text { Electric } \\
\text { HWC }\end{array}$ & $\begin{array}{l}\text { Electric + } \\
\text { solid fuel } \\
\text { heater }\end{array}$ & $\begin{array}{c}1+ \\
\text { terrace }\end{array}$ & $\begin{array}{l}\text { Corrugated } \\
\text { iron }\end{array}$ & $\begin{array}{c}\text { Bath, separate } \\
\text { toilet }\end{array}$ & Yes & BIW & Yes \\
\hline $\begin{array}{c}3 \text { bedroom } \\
\text { wage workers }\end{array}$ & $\begin{array}{c}1969- \\
84\end{array}$ & 830 & 3 & 100 & $\begin{array}{l}\text { Electric } \\
\text { HWC }\end{array}$ & $\begin{array}{c}\text { Electric + } \\
\text { solid fuel } \\
\text { heater }\end{array}$ & 0 & $\begin{array}{c}\text { Corrugated } \\
\text { iron }\end{array}$ & $\begin{array}{c}\text { Bath, separate } \\
\text { toilet }\end{array}$ & Yes & BIW & Yes \\
\hline $\begin{array}{c}4 \text { bedroom } \\
\text { wage workers }\end{array}$ & $\begin{array}{c}1969- \\
84\end{array}$ & 800 & 4 & 100 & $\begin{array}{l}\text { Electric } \\
\text { HWC }\end{array}$ & $\begin{array}{c}\text { Electric + } \\
\text { solid fuel } \\
\text { heater }\end{array}$ & 0 & $\begin{array}{l}\text { Corrugated } \\
\text { iron }\end{array}$ & $\begin{array}{l}\text { Bath, separate } \\
\text { toilet }\end{array}$ & Yes & BIW & Yes \\
\hline $\begin{array}{c}5 \text { bedroom } \\
\text { wage workers }\end{array}$ & $\begin{array}{c}1969- \\
84\end{array}$ & 980 & 5 & 100 & $\begin{array}{l}\text { Electric } \\
\text { HWC }\end{array}$ & $\begin{array}{c}\text { Electric + } \\
\text { solid fuel } \\
\text { heater }\end{array}$ & 1 & $\begin{array}{l}\text { Corrugated } \\
\text { iron }\end{array}$ & $\begin{array}{c}\text { Bath, separate } \\
\text { toilet }\end{array}$ & Yes & BIW & Yes \\
\hline
\end{tabular}

Table 5 : Chart of hydro house types and sizes compared to state housing standards 


\begin{tabular}{|c|c|c|c|c|c|}
\hline & insulation & guttering & $\begin{array}{l}\text { Additions } \\
\text { /variations }\end{array}$ & storage & $\begin{array}{l}\text { Intermediary } \\
\text { space }\end{array}$ \\
\hline WAITAKI & No & No & No & No & No \\
\hline ROXBURGH & No & No & $\begin{array}{l}\text { Huts } \\
\text { placed } \\
\text { alongside }\end{array}$ & No & No \\
\hline OTEMATATA & No & No & $\begin{array}{l}\text { Huts } \\
\text { placed } \\
\text { alongside } \\
\text { and some } \\
\text { colour } \\
\text { variations }\end{array}$ & No & No \\
\hline 1MTT & No & No & No & $\begin{array}{l}\text { Storage } \\
\text { sheds/ } \\
\text { huts } \\
\text { provided }\end{array}$ & No \\
\hline TWIZEL & Yes & Yes & $\begin{array}{l}\text { Additions } \\
\text { as } \\
\text { required, } \\
\text { variation in } \\
\text { house } \\
\text { sizes }\end{array}$ & $\begin{array}{l}\text { BIW and } \\
\text { cabinets }\end{array}$ & $\begin{array}{l}\text { Sheltered } \\
\text { entrance }\end{array}$ \\
\hline CROMWELL & Yes & Yes & $\begin{array}{l}\text { Variations } \\
\text { in house } \\
\text { sizes, no } \\
\text { additions }\end{array}$ & yes & Yes \\
\hline
\end{tabular}

Table 6: Design changes assessment of houses

Insulation: While some insulation was provided by the proximity of family accommodations in the early camps, it became an issue at Otematata and Twizel as the families were allocated houses that were located on individual lots with less proximity to their neighbours. When this happened heating costs were affected and demands for insulation and heating alternatives as well as requests for subsidised electricity became more prevalent ${ }^{135}$

Guttering: Guttering does not seem to be an issue with occupant satisfaction as it is not mentioned by either Campbell or Sheridan. However, its effect on the areas directly surrounding the houses to have been recognised by the MoWD with the inclusion of guttering on the houses at Twizel, the second hydrotown in the region to have defined gardens and individual lots surrounding the family houses.

Additions/variations: Additions and variations to the housing signalled a sense of occupant satisfaction and long term occupation intentions when performed by the residents. However, by Twizel the MoWD was incorporating more of the

${ }^{135}$ Sheridan pp91-2 
occupants desires into the housing (led by union and committee pressure) and a variation in houses sizes allocated according to family size (as opposed solely to occupant employment status and ranking) and construction of additions as required was introduced.

Storage: Storage appears to have increased in importance as the years passed. This would seem to suggest that the occupants were bringing more belongings to the houses, which itself suggests occupant anticipation of comfortable dwelling and long term occupation.

Intermediary space: Intermediary space between the outside and inside of a house is not a factor which would often be expected in the design of temporary accommodations but had made its way into the house design by Twizel.

The MoWD Department of Housing, in reference to state housing, noted that

"The maintenance of these high standards is an important factor in the popularity of the housing scheme. The tenants must be contented because no scheme can hope to survive unpopularity in a democratic community"136.

Judging by the changes in design instigated by the occupants throughout the progression of hydro towns in the region, it would seem that no housing design can hope to survive unpopularity in an autocratic community either.

Although occupant surveys have not been conducted in this research (due to the unreliable data provided by the small sample available), satisfaction surveys were conducted at Waitaki (by Campbell), Otematata (by Sheridan) and Twizel (by Taylor et al) and the results are consistent with the theory that occupant needs and the satisfaction of the majority were reflected in union and committee demands and housing retention requests.

It follows that, despite having lower standards than required in state housing, the occupants were reasonably satisfied with the housing at Otematata and Twizel during the applicable project years as the occupants' desires were met with warmer, larger houses which were varied in design and able to be altered as needed.

${ }^{136}$ Ministry of Works, State Housing in NZ, p 46 


\section{Transportability and Transformability}

Transportability was a major consideration in the design and manufacture of the accommodations at the camps. However, transportability was often forgotten once the accommodations were on site. For example, the community in the Waitaki camp successfully petitioned for coal ranges. Of course these required chimneys which were built from bricks and seriously affected the transportability of the houses at both Waitaki and, when the practice was continued, at Roxburgh.

At Roxburgh, solutions for transportation of the new houses required a lot of improvisation and a huge amount of man power. As technology improved, so did the options for transportation, culminating in the modular hostels at West Arm for 2MTT which were removed from site by removing the attachments between modules and to services, driving a truck with a lowerable deck under the module, removing connections from the blocks under the modules, raising the deck, then driving onto a barge which transported the entire truck and load to a wharf at Manapouri ${ }^{137}$, where the truck drove off the barge and to the next site for the hostel module (the majority of which are at Te Anau Holiday Park). Here they were unloaded by transportable crane onto new blocks (although they were initially stored on drums at Te Anau Holiday Park until the site was prepared) and were only dependent on their connections, services provision and foundations to be fully compliant with the NZBC.

\footnotetext{
${ }^{137}$ See Appendix $\mathrm{H}$, photos $\mathrm{H} 4,6,8$ and 9 and compare with 1MTT in Appendix E, photo E8 and Twizel in Appendix F, photos F7 and 8
} 


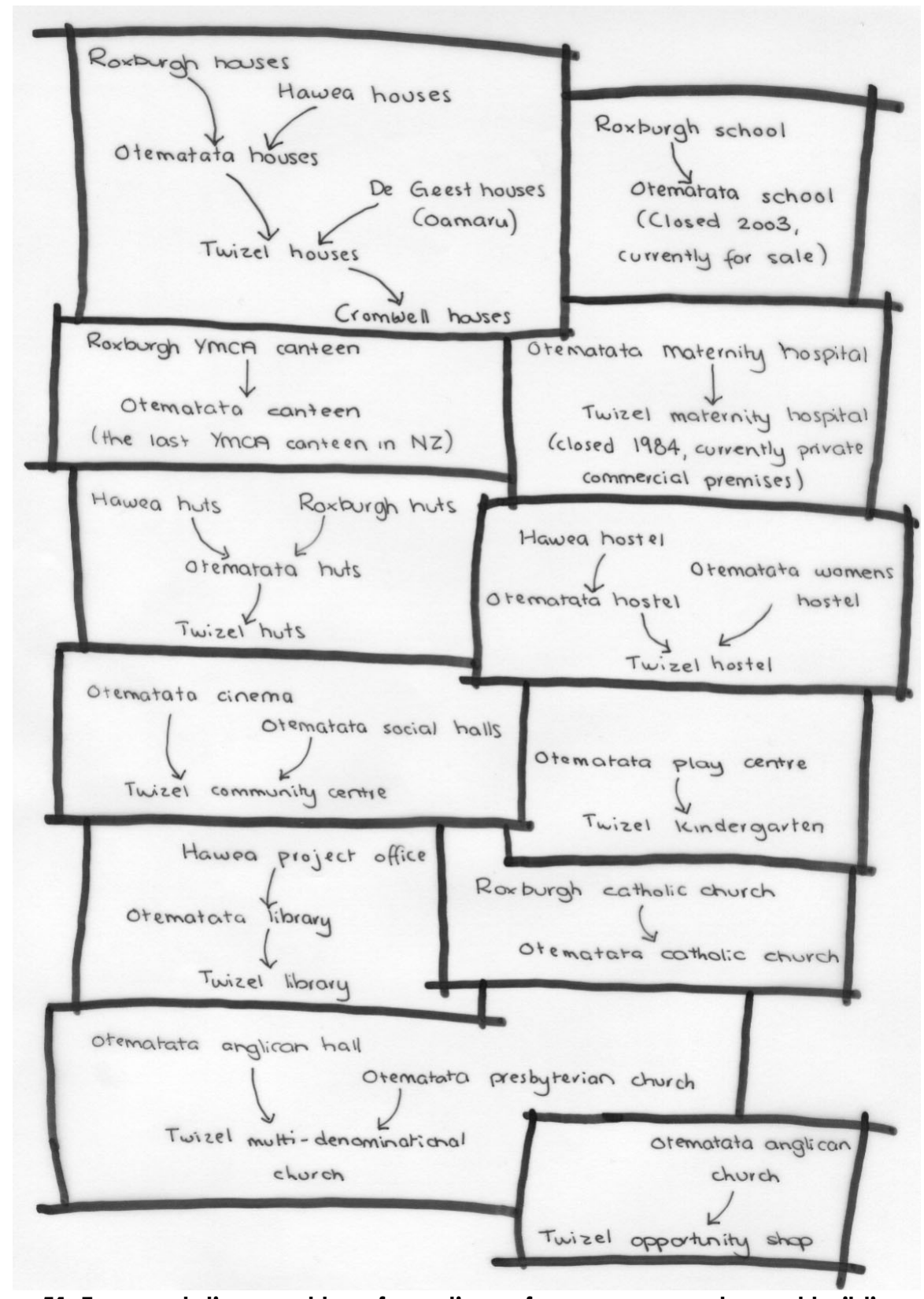

Figure 51: Transportations and transformations of some commonly used buildings (Graph by the author)

note: this is by no means a complete flow chart of all transportations or transformations, but intended to demonstrate the extent of these. 


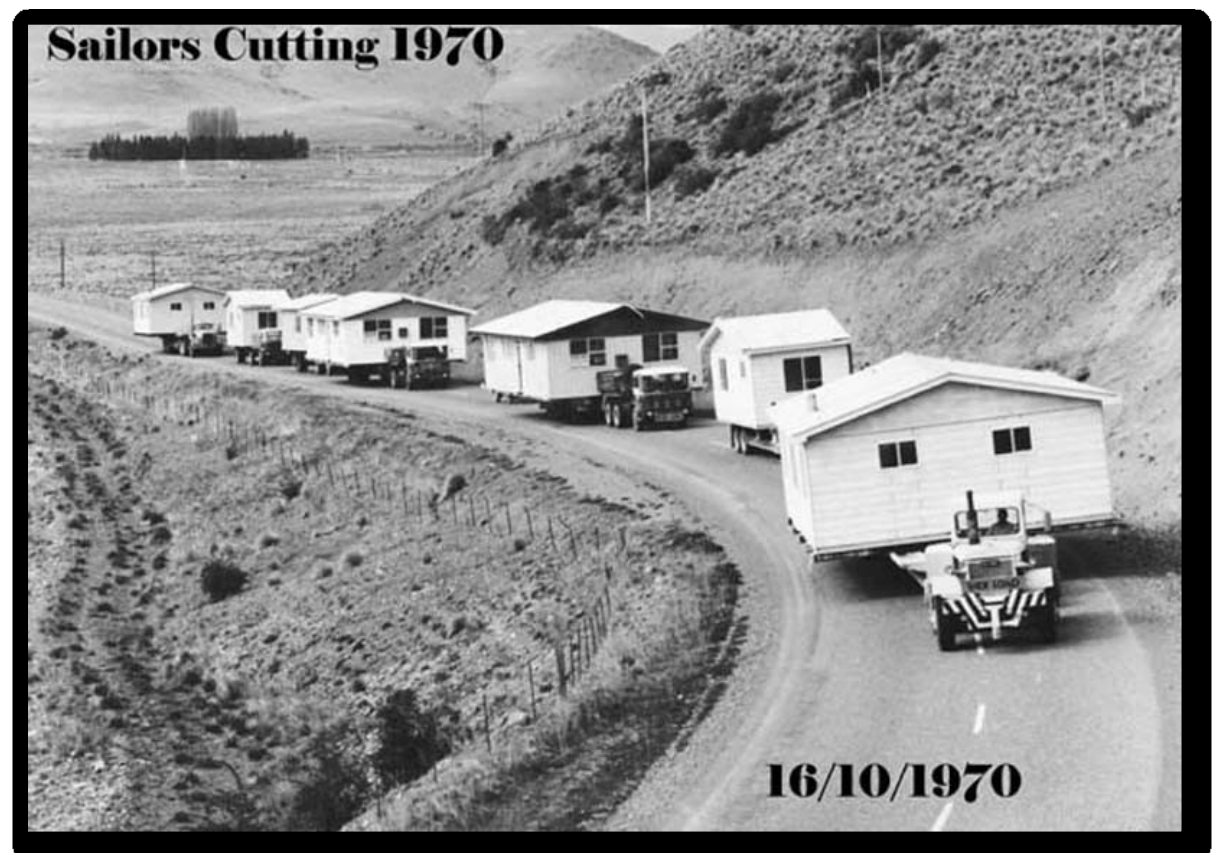

Figure 52: Houses being moved to Twizel 1970

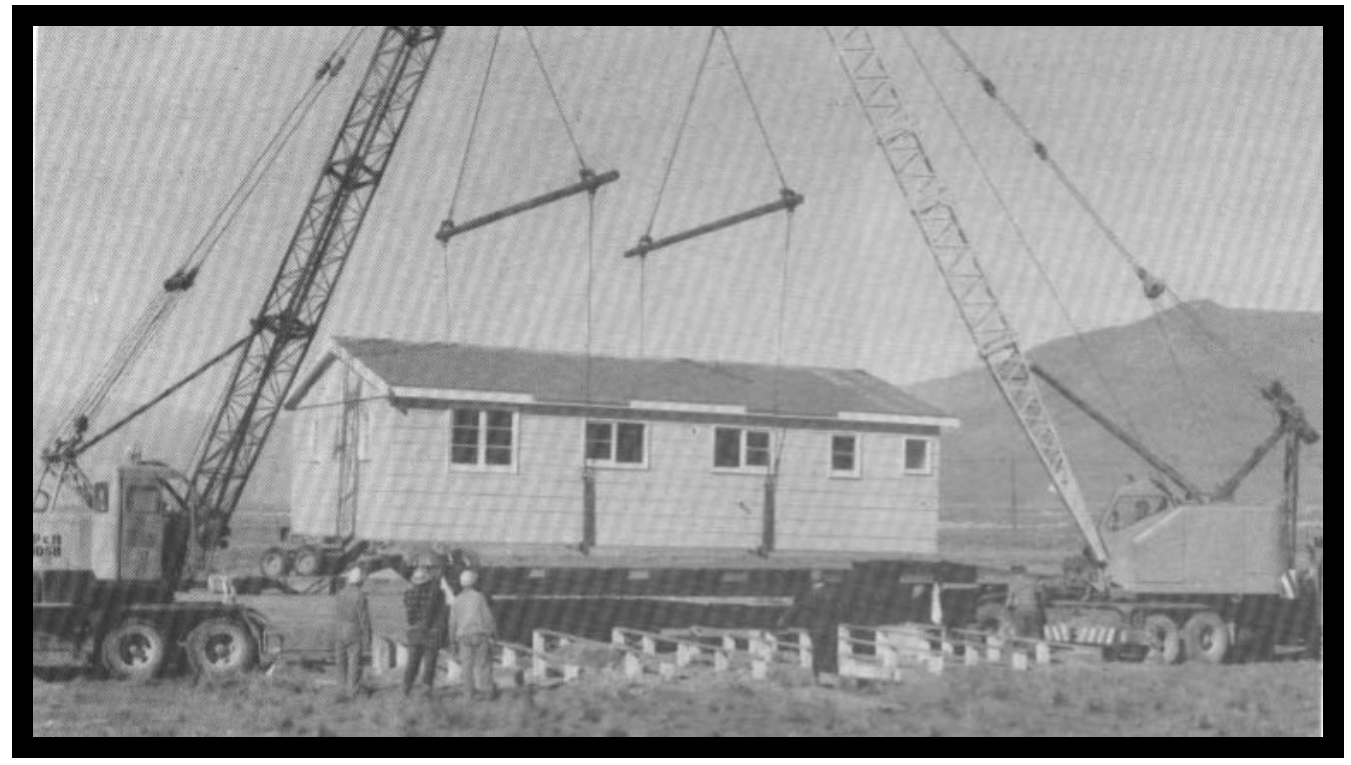

Figure 53: First house being lifted into place at Twizel, April 29, 1969

"So what remains? On the approach to Otematata you can see moulded into the farmland the long hollows where the scrapers clawed out the earth to pack the dam. You can find the foundations of the shops. The hall still stands along from the fire station; the school has closed down. You can find the old maternity hospital - but not in Otematata. It has moved up the road to Twizel, and these days operates as a backpackers. In Otematata, gnarly old crab-apple trees stand in abandoned backyards. Look and you will find the faint footprint of old workers' huts among the grass and stone. When you grub around you are reminded once again that Otematata means 'place of flint'. The large concrete blocks that lie like 
ruins are the remnants of the sewerage system dug up and left there as soon as the 'permanents' left town. They say the substandard housing ensured Otematata's future. The huts that had come from the Roxburgh project were decommissioned from future hydro projects and stayed....the single men's hostel is now the Country Inn. The old offices of the NZED is now a private residence. The old bus depot is now a honey depot..... upriver and the place of the single men's huts that once stretched all the way up to Site Road has given up its memory to a golf course....."138

Houses required a more complex process for transportation in order to incorporate the social, local planning and legal requirements which changed in the periods between initiation of new hydro projects. In particular, the siting of the houses had the potential to create huge difficulties in the transportation of the houses, as did the preparedness of services and local roads.

The use of modules to create transportable accommodation in the hydro towns made a significant impact on the ability to redesign and transform the accommodation. At the planning stage of each new hydro town the design authority could use the houses, huts and hostels as a template to design the new accommodation on. The modifications were easier to make to modules than would have been the case with most other types of transportable buildings.

Not only could the accommodation be altered, but the use of various other buildings could also be easily changed. For example, the cinema and social halls from Otematata were combined to become the Twizel community centre, the project office from Hawea became the Otematata library and then the Twizel library and the Otematata Anglican church became the Twizel op shop (for more examples, see fig 51). These transformations have continued, both the Otematata sports centre and the Otematata community centre were for sale by tender in December 2006 for removal and repurposing.

Transformations have had an impact on the life expectancies of these buildings, which each new addition and/or alteration upgrading either a part or all of the building and thus lengthening its lifespan. However, these buildings were designed to be temporary and many of them have undergone transformations which have replaced portions, leading to unequal life expectancies of different

${ }^{138}$ Lloyd Jones, Benmore, pp 48-9 
parts of the building. As each part degrades it is replaced, making it harder to define exactly which buildings still fall into the category of hydro project buildings - what is the percentage of originality that constitutes an 'original' building and does this include the design or merely the materials?

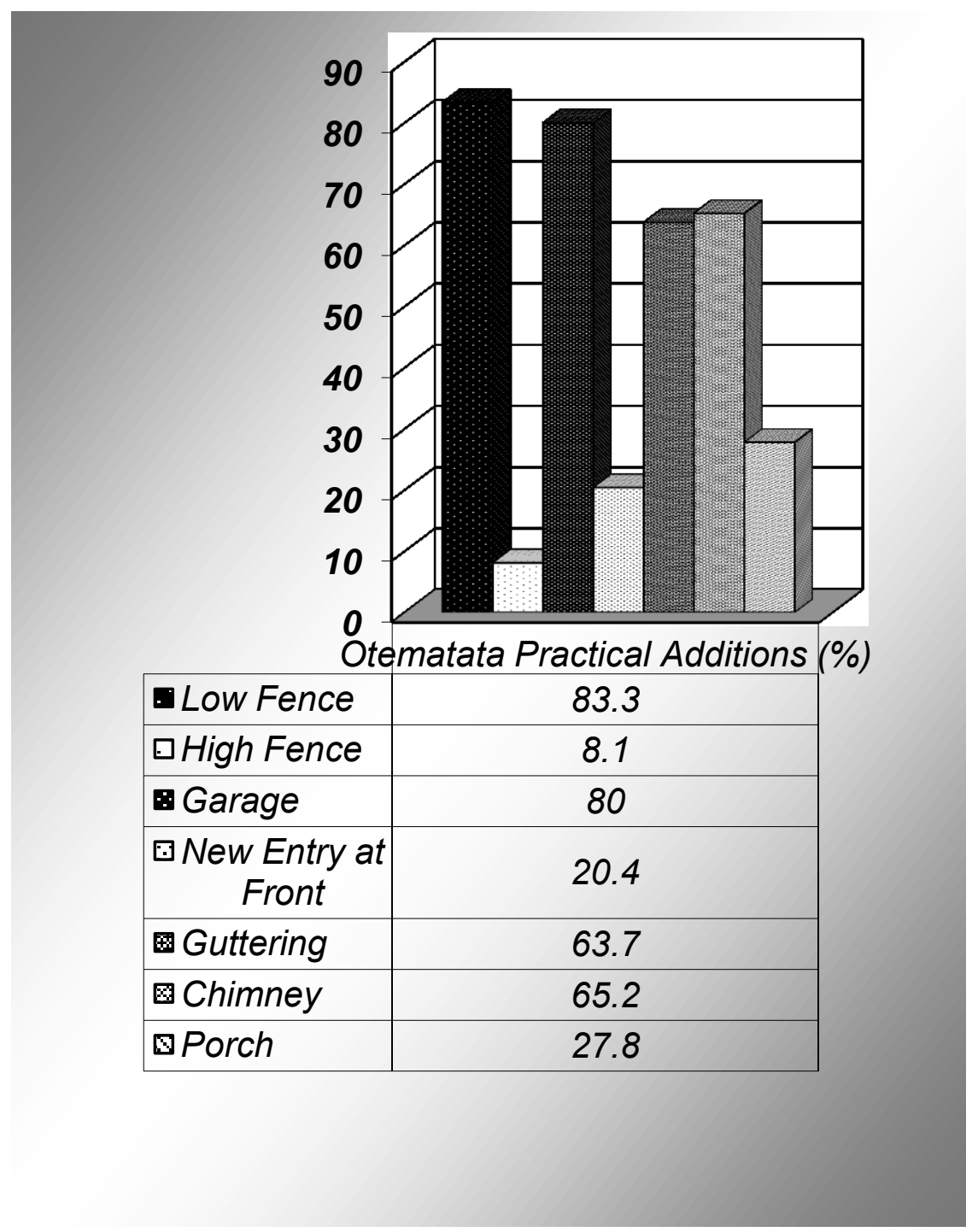

Figure 54: Practical additions as externally visible at Otematata, 2005

The practical additions made to the houses at Otematata (as per fig 54) since private ownership have closely shadowed the transformations made the houses which were transferred to Twizel - guttering, fences, garages, porches and more efficient methods of heating have been added.

Where practical transformations have been made to many of the existing hydro houses the majority of residents in both Twizel and Otematata have chosen to incorporate distinctive elements in order to create individuality in the appearance of their homes (this has been further discussed in the 'individualisation' part of this research). 


\section{Permanence}

Industrialisation has led the majority of homeowners to see permanence as equating to heavy (ie: permanence is concrete, brick, stone, etc). Thus the values of the houses in Otematata and Twizel initially were very low and many alterations to the homes have been made to make them appear more solid. In fact, the houses at Otematata, although a vast improvement on the tents used prior to WWII, were not designed to outlive the project. Once the upgrade in housing for Twizel was implemented it became more apparent that these houses could outlive the project.

So what defines permanence in a building? In today's market we often look to a new building to last 30 - 50 years. We no longer look to a "permanent" building to outlive us as we did just three decades ago. Therefore, there are more "light" looking buildings utilising today's technology.

So how did the houses at Otematata suddenly appear to be permanent enough to satisfy the community that the township should be retained? In answer to this, we should perhaps look more closely at the history rather than the structures. After 14 years of living in these houses and surrounded by a community of like-minded people, the idea that the township could be completely removed and the community disbanded must have seemed highly undesirable the occupants of these houses, particularly the women and children (the men would be more focused on the completion of the job).

Unfortunately the delays between completion of Aviemore and the move to the Upper Waitaki projects based in Twizel meant that the community was even more fractured than may have otherwise occurred with typical migration between projects. Some families faced long periods of unemployment, others moved to 1MTT. The businesses in the town began to shut down as noone had the financial security to spend more money than was strictly necessary and the population declined.

For those who stayed on, there was a long wait of two to three years between the beginning of the decline in population and the removal of half of the houses and introduction of a new wave of migrants to the town, many of whom had no concept of the social values of the previous community. Add to this the siting of 
the town at a distance from any other community or shopping facilities and it is no wonder that many of the homes here appear to be holiday homes that are not in regular use today.

Twizel, on the other hand, was established at a time when many employees were looking towards retirement (having started in the area in the 1930s on the first Waitaki project). The houses had been upgraded four times within the working life of these people and they had lived in them for around ten years. If any township was to survive this was the one. Thus it was the community that the residents largely fought to save, with diversification of the local economy helping it along.

The lack of permanence also translated into a large number of houses which were not well maintained. Non-ownership of the properties meant that the inhabitants considered that maintenance was not their responsibility and this led to some houses being poorly looked after and surrounded by little in the way of garden (particularly by those workers who did not intend to stay long), while others were well presented, with beautiful gardens.

"Due to a combination of the fact that the construction period will be unusually long (anticipated to extend to 25 years) together with already stated factors of the development of the project within a well established existing town and the likely emergence of a Cromwell which will be significantly larger than that which exists at present, it is considered an essential prerequisite that all development be carried out to permanent standards. Development standards should be in line with those which are acceptable both nationally and locally. It is particularly important that no houses or project or private buildings be established which, by their appearance and/or standards of construction, would tend to give the indication of being temporary rather than permanent ${ }^{139}$ ",

While the design of the housing was slowly coming into line with the design standards of state housing, the sections on which the houses were placed were also progressing towards the standards of permanent homes.

139 Joint Planning Committee, p5 
What is not visible in the townships today, but which made an impact at the time that these houses were part of hydro townships, was the great difference between the upkeep in houses. Many workers felt that the houses were temporary and, therefore, there was no need to keep them tidy and in good condition and that the MoWD was responsible for their upkeep as their owners.

WJ Campbell noted in Roxburgh that: "Both Jan and Elsie were industrious, but they had no intention of staying in Hydrotown for long, so they ignored the appearance of their section and house" 140 and, "Unlike many of their neighbours who allowed beer bottles, fruit cases, and parts of motor cars and bicycles to clutter up their sections, the Smiths took a pride in their home and were continually making efforts to improve it. Jim was a keen gardener in an area where keenness was absolutely necessary, for the poor soil discouraged all but the genuine lovers, and the temporary nature of the settlement militated against long-term improvement plans."

Along the same lines, those who were not intending to stay a long time often made less effort at integrating into the community, choosing to isolate themselves from the social life of the town.

The appearance of permanence, by individual sections, established gardens, trees connection of houses to the ground and site (via foundation surrounds and guttering, etc) and individualisation seems to be more important than the actual lifespan of the materials in the occupants desire to retain their houses post project.

Where the occupants had chosen to maintain their houses and gardens they had intended to live in them for an extended period of time. There does appear to be a correlation between the amount of maintenance (and number of additions and alterations) and the amount of time that the occupants intended to live in the houses.

\footnotetext{
${ }^{140}$ WJ Campbell, p 52

141 ibid, p 51
} 


\section{Materials}

Prior to the Waitaki camp, house and hut roofs were made of canvas and not very waterproof (able to withstand light frosts and showers only). At Waitaki this was upgraded with malthoid roofs and timber walls provided for all huts and houses. While this was a major improvement to the previous accommodations, the buildings were still without insulation, guttering, electricity or running water.

During WWII, however, imported materials became scarce as they were coopted into munitions production (for example, steel, copper, electrical cable and conduit, paint ingredients ${ }^{142}$ ). After the war, soldiers returned home to find a housing shortage.

At Roxburgh more men brought their wives and families with them as a result of the post-WWII housing shortage. This translated into more demands on the housing. Many of the houses were transported from Waitaki, but the external timber was replaced with weatherboards and a pineboard layer was added to the interior of the dwelling and left bare for the occupants to decorate. Also at Roxburgh services were added - electricity to all accommodations and indoor plumbing (both running water and a sewerage system) to all bathrooms, toilets, kitchens and laundries.

At Otematata the houses were further upgraded by covering the roofs with corrugated iron (although there was still no guttering) and the coal ranges were replaced with electric ovens (although there was still no insulation). Needless to say, although these houses had better roofs, they were even colder than those at Roxburgh as they no longer had coal ranges.

After living in two hydro camps, the women led the demands for alterations to the houses that were to be provided at Twizel. Predominant amongst their successful demands were extensions in lieu of huts being added as families grew, garages to be added (Otematata had been the first camp to tarseal the streets), gardens to be provided, hot water cylinders and insulation to be installed, electricity supply costs reduced, guttering and covered entrance ways to be added ${ }^{143}$. These items, once added, forever changed Twizel from being a hydro village into a town of hydro workers' homes.

\footnotetext{
${ }^{142}$ Ministry of Works, p44

143 Sheridan, pp91-2
} 
The comfort of these homes was the argument behind the retention of the town and success of it (measured on occupant satisfaction ${ }^{144}$ and the desire to purchase their houses from the MoWD. Although Otematata had also been successful when measured by these criteria, there had still been a concentrated effort by the occupants to obtainchanges to the housing before the move to Twizel) in comparison to the previous camps. This is also a large part of the history behind the decision to provide permanent houses at Cromwell in lieu of another transportable camp.

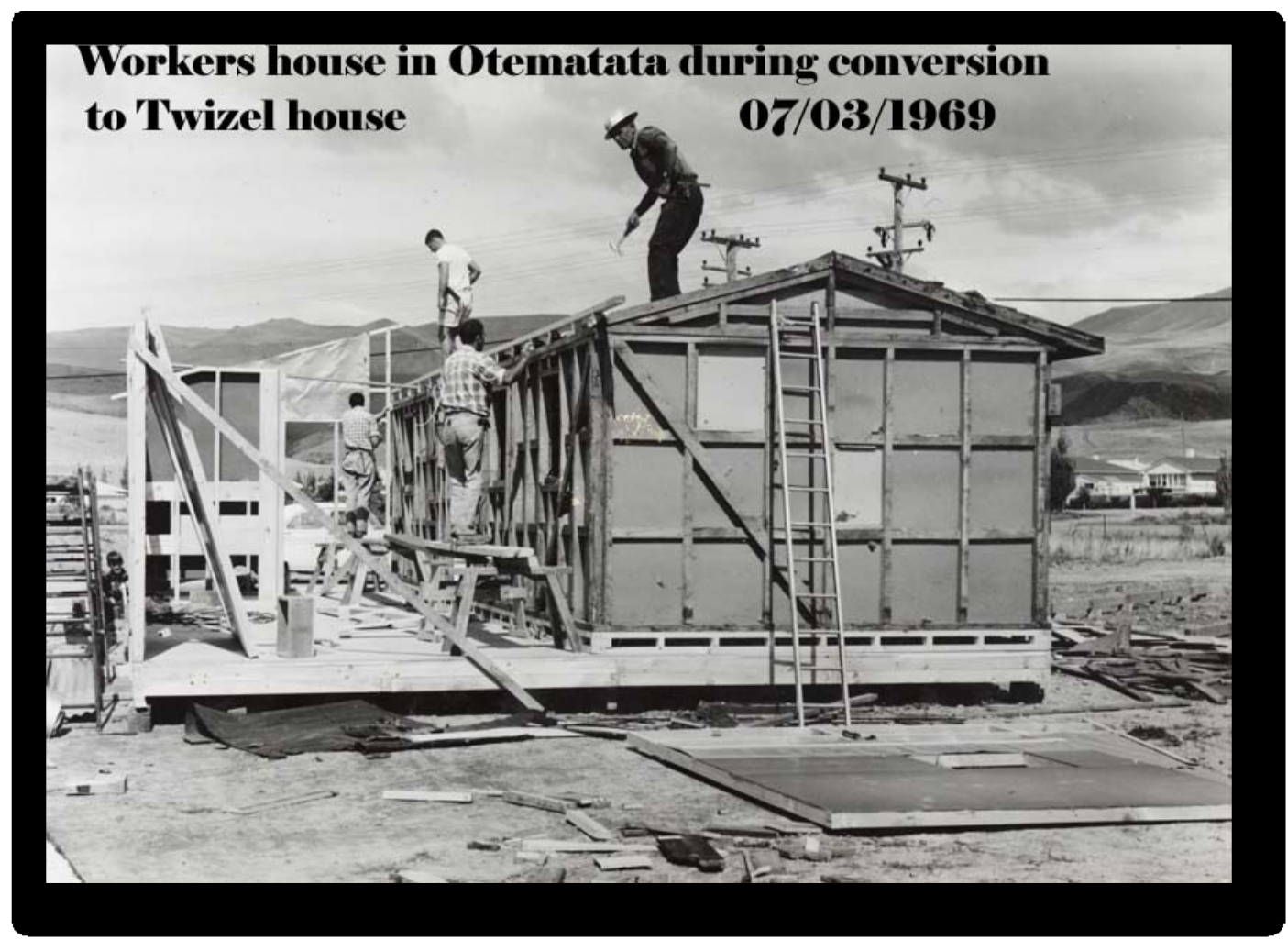

Figure 55: Workers house at Otematata during conversion to Twizel house, 1969 (Photo courtesy of Southern Alps Photos and Gifts)

The MoWD files at the National Archives (Dunedin) show how the question of materials and construction became very important as NZ housing standards were improved - when it became evident that some temporary housing was to be required at Cromwell (in addition to the 511 permanent houses being provided), an investigation into the standards of the transportable houses at Twizel was made (in-house at the MoWD, with an eye to altering them to raise the quality of accommodation to a par with that in the permanent houses at Cromwell).

\footnotetext{
${ }^{144}$ Taylor et al “A Case Study of Twizel” pp4-5 and Sheridan, pp91-2
} 
The MoWD found that the houses at Twizel were built to meet most of the standards of state rental housing at the time, but with reduced floor areas and in a modular format. The Twizel houses did not meet the specifications of housing at Cromwell (built by the NZ Housing Corporation) and would need the following modifications in order to do so:

- addition of patio/verandah

- screened entry into living room from outside

- relocation of juno and cylinder to give wet-back system

- improvements to kitchen layouts

- provision of shower over baths ${ }^{145}$,

Concern was also expressed that the Twizel houses did not meet NZ Standards 1900 (Model Building Bylaw) and 3604 (Timber Framed Buildings) and that both floor areas and bracing would need to be upgraded in order to do so ${ }^{146}$.

The NZ Housing Corporation found that to alter and relocate a $720 \mathrm{sq} \mathrm{ft}$ house from Twizel to the temporary subdivision at Cromwell would cost c. $\$ 33,600$ $\$ 36,300$ (with a finished size of $850 \mathrm{sq} f \mathrm{ft}$ ), whereas building a new $1100 \mathrm{sq} \mathrm{ft}$ light clad house in the temporary subdivision would cost c. $\$ 36,200^{147}$.

The planning of the layout of the houses also needed to be altered (in comparison to that of the permanent houses) in order to

"camouflage the repetitive nature of the individual houses ${ }^{148}$ "

Regardless, the tradition of altering and transporting houses from a previous hydro town was continued and 88 houses from Twizel were relocated to the temporary subdivision at Cromwell.

\footnotetext{
${ }^{145}$ letter from RA Buck to DJ Bewick, Project Engineer, dated 30 January 1979

146 ibid

${ }_{147}^{147}$ National Archives (Dunedin) file 90/251, dated 10.2.81

${ }^{148}$ RM Moen, "Report on Concept for Temporary Twizel Housing, Cromwell Borough", p2
} 


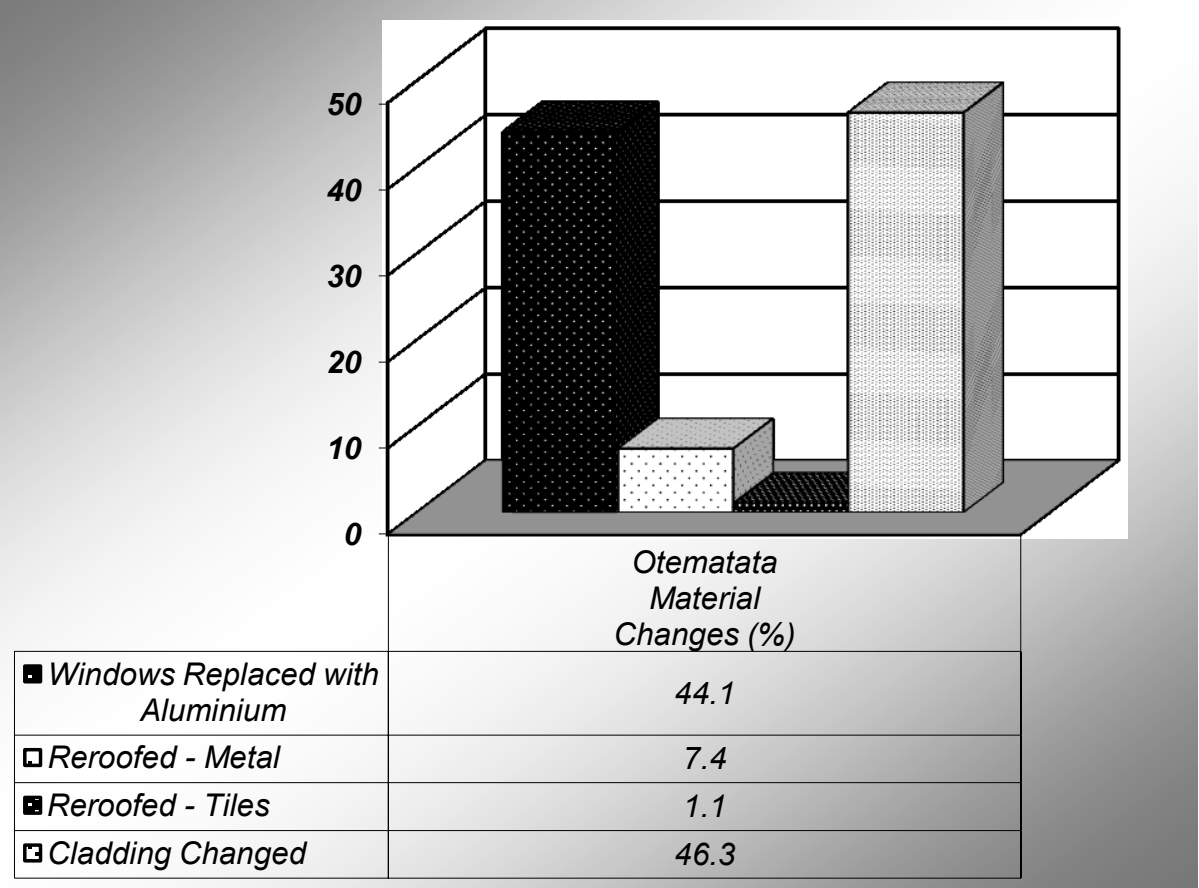

Figure 56: Materials changes made to hydro project houses at Otematata as externally visible in 2005

Meanwhile, half the hydro project houses at Otematata were still in existence and their inhabitants were changing the materials to both express their individuality and to meet the higher standards of housing as time progressed. As can be seen in the graph above, the largest number of externally visible material changes made to houses at Otematata, since the transferral into private ownership of these houses, have been related to thermal comfort, maintenance and appearance. Thermal comfort was also the most predominant concern expressed by the community when requesting design changes to the houses for Twizel, while maintenance and individual appearance were the two largest concerns of the occupants who took private ownership at Otematata (as these issues were previously addressed by the MoWD). 


\begin{tabular}{|c|c|c|c|c|c|}
\hline & & Transportability & Lifespan & Materials & $\begin{array}{l}\text { Changes made } \\
\text { (from last } \\
\text { camp) }\end{array}$ \\
\hline WAITAKI & & Brick chimneys & $\begin{array}{l}\text { Built to } \\
\text { last for } \\
\text { single } \\
\text { project }\end{array}$ & $\begin{array}{l}\text { Timber with } \\
\text { malthoid roof }\end{array}$ & $\begin{array}{l}\text { Timber sidings } \\
\text { and malthoid } \\
\text { roofs }\end{array}$ \\
\hline ROXBURGH & & Brick chimneys & $\begin{array}{l}\text { Built for } \\
\text { short } \\
\text { lifespan } \\
\text { (10-15 } \\
\text { years) }\end{array}$ & $\begin{array}{l}\text { Weatherboard } \\
\text { with malthoid } \\
\text { roof }\end{array}$ & $\begin{array}{l}\text { Weatherboards, } \\
\text { internal } \\
\text { plumbing and } \\
\text { electricity }\end{array}$ \\
\hline OTEMATATA & & $\begin{array}{l}\text { Yes, not even tied to } \\
\text { foundations }\end{array}$ & Short & $\begin{array}{l}\text { Weatherboard } \\
\text { with } \\
\text { corrugated iron } \\
\text { roof }\end{array}$ & $\begin{array}{l}\text { Corrugated iron } \\
\text { roofs, electric } \\
\text { ovens (ie: no } \\
\text { chimneys), } \\
\text { predecorated } \\
\text { interiors, T- } \\
\text { shaped }\end{array}$ \\
\hline 1MTT & $\begin{array}{l}\text { Mana } \\
\text { pouri }\end{array}$ & Transportable & Short & $\begin{array}{l}\text { Weatherboard } \\
\text { with } \\
\text { corrugated iron } \\
\text { roof }\end{array}$ & Rectangular \\
\hline TWIZEL & & Transportable & Short & $\begin{array}{l}\text { Weatherboard } \\
\text { with } \\
\text { corrugated iron } \\
\text { roof }\end{array}$ & $\begin{array}{l}\text { Porch, garage, } \\
\text { coal-burning } \\
\text { stoves (as at } \\
\text { Roxburgh, } \\
\text { requiring } \\
\text { chimneys), } \\
\text { guttering }\end{array}$ \\
\hline CROMWELL & & Not transportable & $\begin{array}{l}\text { Long }(30 \\
\text { years }+)\end{array}$ & $\begin{array}{l}\text { Various - } \\
\text { masonry and } \\
\text { timber clad }\end{array}$ & $\begin{array}{l}\text { Built on site, } \\
\text { individual title, } \\
\text { some masonry, } \\
\text { fencing }\end{array}$ \\
\hline
\end{tabular}

Table 7: Materials changes assessment of houses

Transportability: An essential element of these towns (other than Cromwell), MoWD alterations and additions, as well as those performed by the occupants but allowed by the MoWD, severely affected the ease of transportation.

Lifespan: Despite being constructed for a short lifespan to meet the temporary nature of the towns, in most cases these houses were also constructed to be transportable, thus ensuring that their use (or the use of the majority of the structure) would far outlive the anticipated lifespan of their design and materials at construction.

Materials: In all cases (except the permanent houses at Cromwell) the materials used in construction of the houses were as light as possible in order to assist transportability. This was contradicted by the additions and variations, as well as 
inclusion of items such as solid fuel burning stoves. This suggests a lack of welldefined design intentions at the planning stage and, perhaps, ignorance of any design intentions post-construction.

Changes made: The changes made through the progression of case studies illustrates the increasing importance placed on occupant satisfaction and desires. Whether used to attract or retain staff, the standard of housing has played an important role in the satisfaction of workers.

While evolution of the housing standards has been performed by the MoWD, it has been largely occupant led and has created deviations from the initial aim of ease of transportability. 


\section{Individualisation}

This segment of the research looks at ways in which the occupants of a property choose to modify its appearance with the intention of expressing their individuality, although changes may also affect the ways in which the dwelling functions. This is different to the segment on transformation, which looks at changes to the structure and materials of the buildings aimed primarily at altering the way in which the building functions.

In Japan prefabrication has become popular (in the second half of the $20^{\text {th }}$ century ${ }^{149}$ ) for several reasons: it has been marketed as a continuation of traditional building methods, the nature of housing as a product and the attention given to use prefabrication to provide bespoke housing being amongst the most important $^{150}$. This had been foreseen by Walter Gropius in 1950 :

"Already in my early beginnings as an architect, $i$ was greatly intrigued and attracted by the Japanese house. Its lightness, its flexibility and pleasing lines impressed me deeply. The restrained order of its stadardised building parts appealed to me as the hallmark of a deeply rooted culture adaptable to any new development. The elements for today's industrial prefabrication seem to be inherent in this ancient modular conception, which simultaneously left freedom for a great variety of compositions, avoiding monotomy.

"I consider it a challenging task for the new generation of Japanese architects to find the fitting links between that flexible, traditional concept of the old craft periods and the new develoment of an industrial basis. With keenest interest I will watch the architectural contributions to come from my Japanese colleagues"151

In Singapore, the state run Housing Development Board has consistently undertaken off-site fabricated precast concrete multi-storey construction (in contrast to the stand alone or multi-unit low scale timber housing constructed by the state in NZ). It has evolved since inception in the 1960s by changing its focus from decade to decade and accepting the life span intentions of the product. In the 1960s, attention was set to providing basic shelter to alleviate the acute

\footnotetext{
${ }^{149}$ Bergdoll and Christensen, p32

150 Gibb, p16

${ }^{151}$ Bergdoll and Christensen, p32
} 
housing shortage. In the 1970s, the aim was to provide a good housing environment with basic facilities. The 1980s were focused on improving the quality of workmanship and finishes and developing communities and creating identity within the housing estates. The 1990s were aimed at providing variety and quality and reducing the construction cost ${ }^{152}$. Thus the Singaporean government was able to constantly improve the product over several decades by accepting and working with the life spans of the buildings.

While it is noted that the NZ hydro housing did improve from project to project, the cases looked at were different from the Singaporean model in that the lifespan of the buildings was intentionally short at construction, yet was ignored in the long term. As a result of this, the stages shown in the Singaporean model have been all applied to the same buildings in the NZ hydro examples, particularly in Otematata and Twizel. By not accepting these buildings as temporary, future evolvements have occurred to the same base structure, including changes made by owners after the hydro projects which expressed their individuality.

Le Corbusier propounded the idea of "uniformity in detail and variety in the general effect"153 and Klaus-Dieter Weiss supposed that the "fascination of historical cities lies in their multi-faceted spatiality"154 (ie: it is the ornaments of varying time periods that create the interest). Both of these statements can be clearly seen in practice in both Otematata and in Twizel on a smaller scale through the various ornamentation and alterations made to transform these houses into individual homes.

While the project communities were in residence, these houses were accepted as all looking very similar as the community all had a similar purpose and a very strong community identity and all houses were owned by a single entity. After resale however, the new owners were no longer a cohesive community with the same focus. Therefore, the residents began changing their identical houses into homes that reflected the residents' ideals.

There is a pattern in low-income mass produced housing overseas that has resulted in an area where uniformity of space and its use has been planned and

\footnotetext{
152 Gibb, p25

153 Le Corbusier p247

154 Schittich p13
} 
yet self-help transformations have resulted in a great variation both visually and spatially ${ }^{155}$. These transformations, alterations and additions have supported the local community by utilising local tradesmen and materials and improved occupant satisfaction. Thus this is a pattern which should be supported and even included in the planning of such settlements.

As Allan Wallis noted, "many theorists of modern architecture and planning have suggested that the ideal prefabricated dwelling would consist of standardised parts flexible enough to allow for, and even encourage, alterations and additions" $" 156$.

The overseas examples indicate that occupants' satisfaction can be affected by the alterations made to their mass-produced house. In situations without design control of any type, individuality expressed in alterations to the home will be judged by those who view it. This judgment will be based on personal taste which will be flavoured by that person's entire life. Therefore, it is logical to conclude that any changes to the mass produced dwelling will attract judgmental evaluation by individuals which may or may not be positive. Either way, this evaluation will affect, to some degree, the relationship between those that have judged the individualisation and those that have performed it and will also affect the satisfaction of the occupants with their dwellings.

There are two effects which may taint this judgment: if community cohesion is promoted in the area, choosing to express individuality (whether attractive or not to the viewer) may be seen as a negative attribute and choosing to express wealth in the individualisation of the dwelling may often arouse emotions unrelated to taste. Therefore, while it can be shown that all individualisation of the hydro houses will affect the occupants' standing in the community, it is not possible in this research to evaluate the exact relationship between social standing and housing, except where location and standard of housing was issued (at some of the projects, not all) according to position and salary.

\footnotetext{
${ }^{155}$ Tipple, p5-6

${ }^{156}$ Wallis, p156
} 


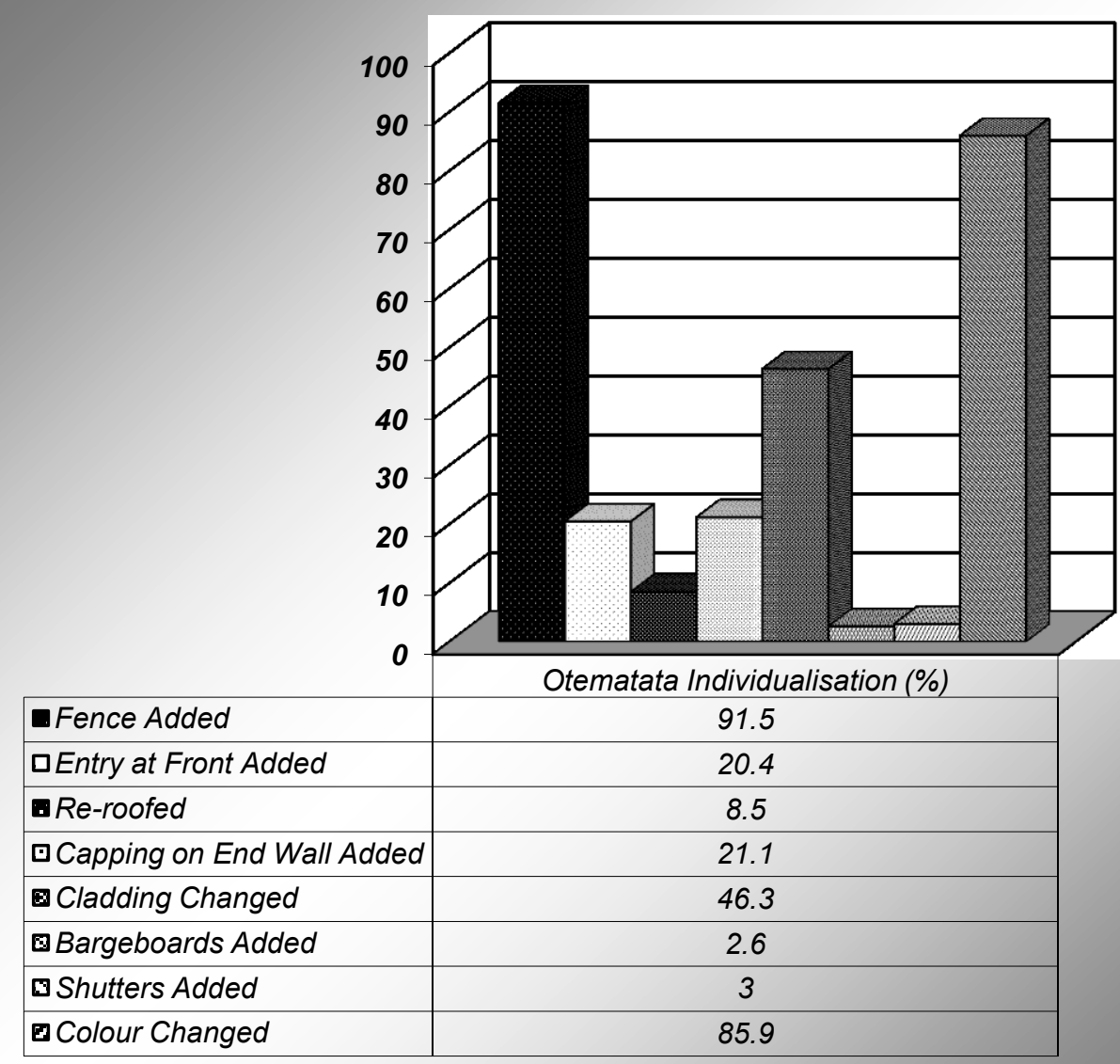

Figure 57: Individualisation alterations and additions at Otematata, 2005

Otematata was designed and run by the MoWD. As was typical in a state run hydro town, there were 6 different types of accommodation available for those employed by the Ministry of Works:

- $520 \mathrm{sq} f \mathrm{ft}$ two bedroom houses for married wage workers

- $820 \mathrm{sq} \mathrm{ft}$ three bedroom houses for married junior staff

- $1000 \mathrm{sq} \mathrm{ft} \mathrm{three} \mathrm{bedroom} \mathrm{houses} \mathrm{for} \mathrm{married} \mathrm{senior} \mathrm{staff}$

- Brick veneer permanent houses for very senior management and the Electricity Division staff who would remain to operate the dams

- Hostels for single staff (and single women who were either staff or wage workers)

- Huts for single wage workers

Each of the different types of accommodation were designed by the MoWD and replicated in numbers to suit (at its peak, Otematata contained 650 houses, 
550 huts and three hostels). Even the interiors were predecorated in standard colours.

When the town was handed over to the Waitaki County Council in 1971, 250 houses were handed over with it. These were sold into private ownership and individualisation began in earnest with the emigration of workers, the retirement of those who chose to stay in Otematata and purchase their homes (who now owned their homes and had no restrictions on changes which they could make to them) and the immigration of those from other areas who had purchased the homes (and who had no experience of the single purpose hydro community).

As can be seen in Figure 57, privacy was the strongest compunction to individualisation, with $91.5 \%$ of houses having added fences by 2005 . Close behind was the simplest form of individualisation - colour change $(85.9 \%$ of houses having been painted a different colour from the original). There has also been a significant percentage of changes made to the cladding ( $46.3 \%)$, however it is impossible to differentiate where this has been done out of need (when the timber cladding has started to fail or insulation has been installed) or desire to individualise.

Taking a drive through either Otematata or Twizel today is a very different journey to when they operated as hydro townships and the large amounts of identical housing were accepted as a reflection of its temporary nature and the non-ownership and single purpose of the inhabitants.

Both Twizel and Otematata display their diverse populations of today in the diversity of the alterations and additions to the houses. This diversity is more obviously displayed in Twizel, most probably as a reflection of the fact that most dwellings in Otematata are second or holiday homes for their owners, whereas the houses in Twizel are more often the primary residence of the owners (this is also evident in the decline of the Otematata town centre to a sole store, whereas Twizel has a wide range of shops and services) ${ }^{157}$. In both examples there does seem to be a reflection of the level of community cohesion in the external appearance of the (owner occupied) housing.

In a discussion of community in regards to state housing, Ben Schrader noted that

${ }^{157} 2001$ Census 
"Sociologists and historians of community have found that the strongest experiences of community happen when the majority of residents are at the same stage of the life cycle, have similar needs and goals, or where remoteness or immobility increases the practical and emotional importance of neighbourly ties"158 and continues to discuss how this has become central to Housing New Zealand's 'Community Renewal' programme ${ }^{159}$.

Thus, state housing in NZ seems to be experiencing a reversal of the process undergone in the hydro towns and more similar to the process experienced in Singapore with prefabricated state housing. Where the hydro towns progressed from a strong sense of community (assisted by repetition of design) towards individualization, state housing in NZ started with an emphasis on minimal repetition of design (individuality of accommodation) and is now attempting to create community cohesion.

\footnotetext{
${ }^{158}$ Schrader, p 205

159 ibid, p206. Housing NZ's 'Community Renewal' programme is a national initiative, launched in 2001
} 


\begin{tabular}{|c|c|c|c|c|}
\hline & Predecorated & $\begin{array}{l}\text { Materials } \\
\text { availability }\end{array}$ & $\begin{array}{l}\text { Evidence of } \\
\text { individualisation }\end{array}$ & Retained \\
\hline WAITAKI & No & $\begin{array}{l}\text { Timber in short } \\
\text { supply }\end{array}$ & No & No \\
\hline ROXBURGH & No & $\begin{array}{l}\text { Post-war } \\
\text { limitations at } \\
\text { beginning }\end{array}$ & No & No \\
\hline OTEMATATA & Yes & Available & Yes & Partly \\
\hline 1MTT & Yes & Available & $\begin{array}{l}\text { Minimal - only on } \\
\text { location } 4 \text { years }\end{array}$ & No \\
\hline TWIZEL & Yes & Available & Yes & Mostly \\
\hline CROMWELL & Yes & Available & Yes & $\begin{array}{l}\text { All except } \\
\text { temporary } \\
\text { houses from } \\
\text { Twizel }\end{array}$ \\
\hline
\end{tabular}

Table 8: Individualisation assessment of houses

Predecorated: This was a community-led change, as a cost-saving measure for the occupants. However, this also further "institutionalised" the houses as, once predecorated, the MoWD did not encourage (but neither did the MoWD actually forbid) redecoration of its houses. Occupants were less likely to redecorate a predecorated house which did not belong to them. Therefore, uniformity was retained more successfully than the houses which were left bare for the residents to decorate in the earlier camps.

Materials availability: This has a significant impact on the ability of the occupants (both during and post project) to individualise their houses. At the early camps, transportation difficulties and materials shortages contributed to a lack of documented (including visible ${ }^{160}$ ) individualisation. Once materials became more easily obtainable and rates of privately owned transportation increased, the evidence of changes made to the houses out of a desire for individualisation (rather than practical needs) becomes apparent in the documentation.

Individualisation: While individualisation was affected by materials availability, another strong influence seems to be the length of time for which the project ran - Otematata and Twizel show a lot of evidence of individualisation in contemporary documentation, where workers were in residence for twice as long as at Waitaki and Roxburgh, where evidence of individualisation is minimal.

Retention: A community-led push for retention shows a correlation with evidence of individualisation, despite predecoration.

${ }^{160}$ See Appendices B and C 
Where materials have been readily available and the workforce has been in occupation for over ten years, individualisation is widespread and discussed frequently in the existing literature.

Where the resident workforce pushes to retain the houses from demolition and/or removal (taken in this thesis to be a reflection of occupant satisfaction) the case studies show that some individualisation has occurred during the project years (ie: while the existence of the town is still deemed 'temporary'). 


\section{Huts + Hostels}

The design of the singlemens huts did not change vastly throughout the progression of the hydro camps.

At Waitaki (1928-35) the huts were $3 \times 2.4 \mathrm{~m}$, with malthoid roofs ${ }^{161}$. At Roxburgh (1949-56) and Otematata (1957-71) the floor space remained the same, but the materials were changed to provide more insulation and protection. The huts were not enlarged until 1MTT in the 1960 s and only to $3.6 \times 2.4 \mathrm{~m}$.

The new huts manufactured for Twizel in the workshops at Otematata were $4 \times 2.6 \mathrm{~m}$. Although the huts had a slightly larger floor area at Twizel and were the first to have porches, any more significant upgrades were rejected by the workers' organisations as unnecessary, despite the strength with which they were fighting for housing upgrades.

The greatest changes to the huts over the years were made in the materials used and the introduction of electricity. In terms of design, the changes made were dictated by the sites - the height that they were raised off the ground level, the shape of the roofs, window sizes, etc. There was little in the way of occupantled changes and no desire by the occupants to transform them into permanent homes.

The general rule at MoWD projects was that wage workers were accommodated in huts and staff were accommodated in hostels. The singlemen were forbidden from flatting or boarding in the project houses.

Huts were replaced completely by hostels at West Arm for 2MTT.

${ }^{161}$ Campbell, p81 


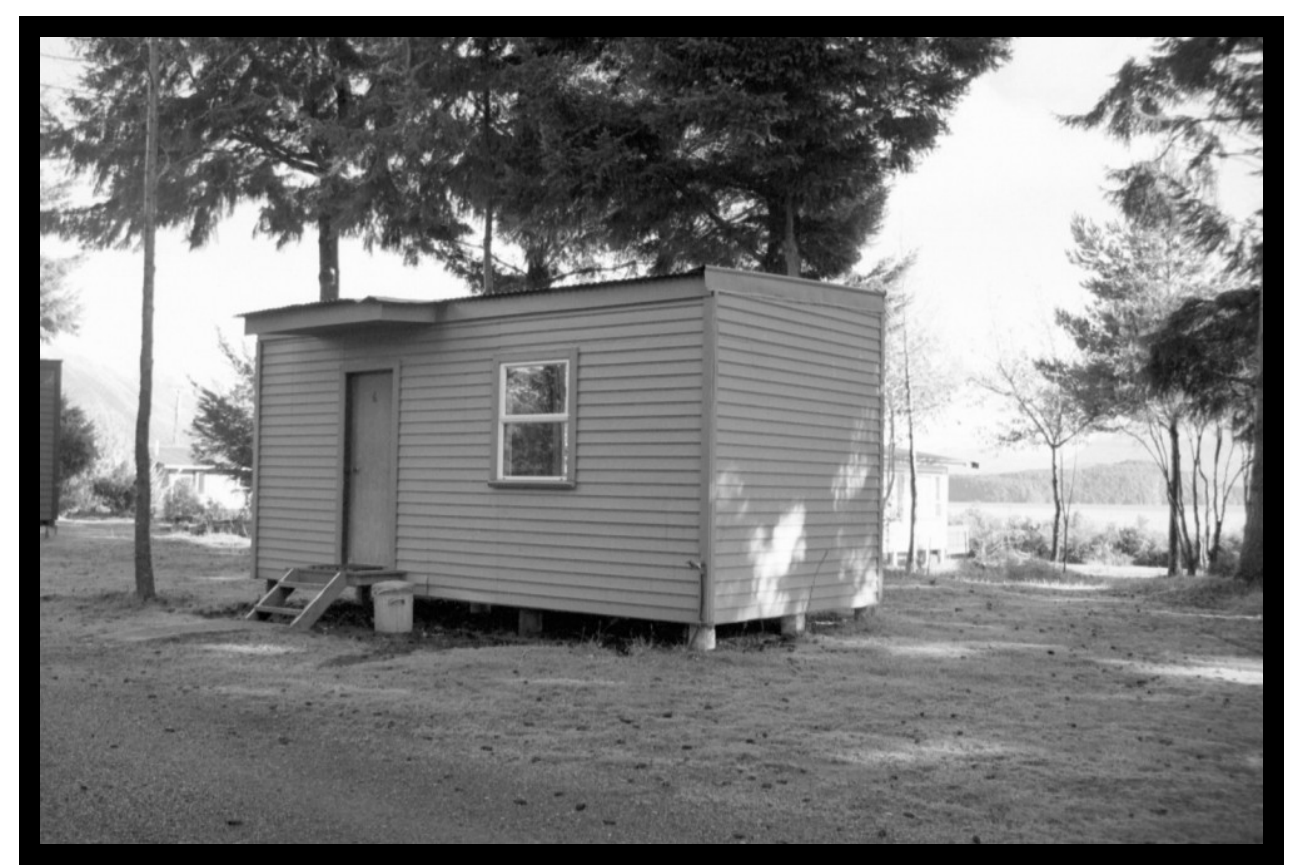

Figure 58: Hut from West Arm (1MTT) at Manapouri Holiday Park

(Photo by the author)

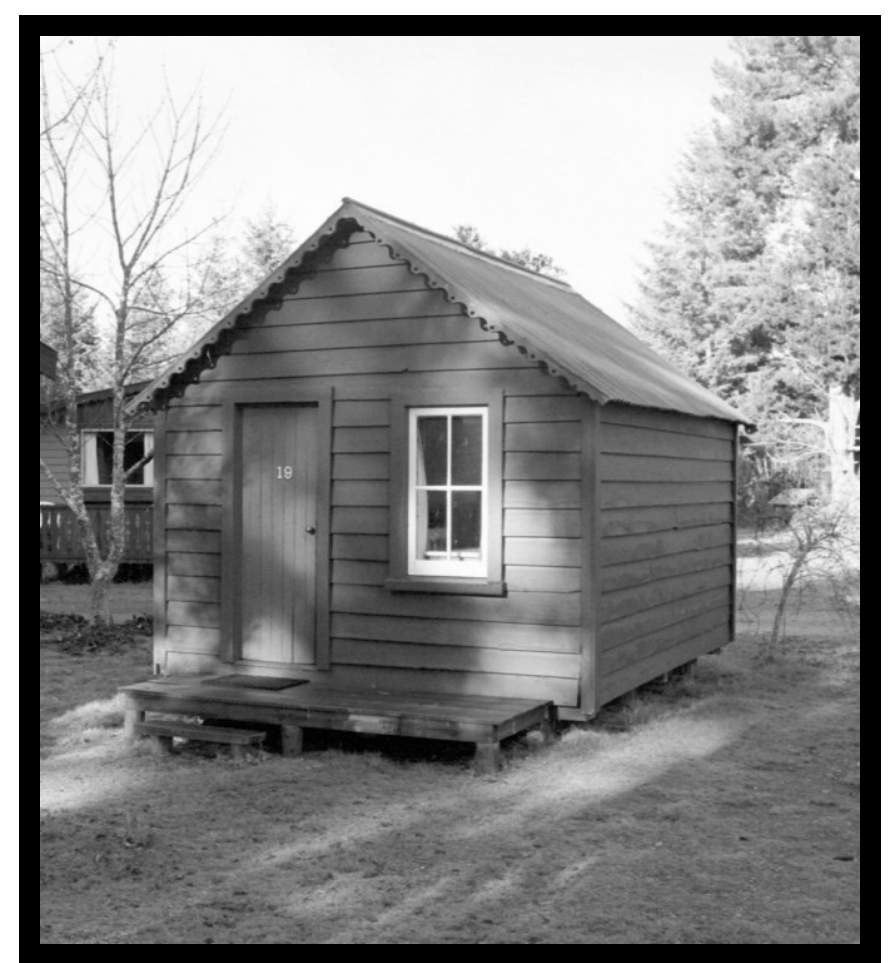

Figure 59: Hut from Deep Cove (1MTT) at Manapouri Holiday Park (Photo by the author) 


\begin{tabular}{|c|c|c|c|c|c|}
\hline & & YEAR & $\begin{array}{l}\text { AREA } \\
(\mathrm{sq} \mathrm{ft})\end{array}$ & ROOF & OTHER \\
\hline Waitaki & 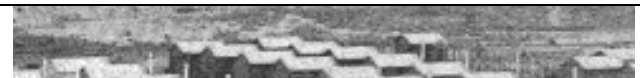 & 1928-35 & 78 & $\begin{array}{l}\text { Malthoid, } \\
\text { pitched }\end{array}$ & $\begin{array}{l}\text { Wood stove, bed } \\
\text { and pallaise }\end{array}$ \\
\hline Roxburgh & 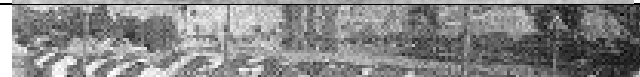 & $1949-56$ & 78 & $\begin{array}{l}\text { Malthoid, } \\
\text { pitched }\end{array}$ & $\begin{array}{l}\text { Stove, bed, table } \\
\text { and stool }\end{array}$ \\
\hline Otematata & & $1957-71$ & 78 & $\begin{array}{l}\text { Corrugated } \\
\text { iron, pitched }\end{array}$ & \\
\hline $\begin{array}{l}\text { 1MTT - } \\
\text { West Arm }\end{array}$ & 8 & 1963-69 & 93 & $\begin{array}{l}\text { Corrugated } \\
\text { iron, sloped }\end{array}$ & $\begin{array}{l}\text { Infra-red } \\
\text { heating, an } \\
\text { electric light, } \\
\text { power point, } \\
\text { chest of } \\
\text { drawers, table, } \\
\text { chair and bed }\end{array}$ \\
\hline $\begin{array}{l}\text { 1MTT - } \\
\text { Deep Cove }\end{array}$ & 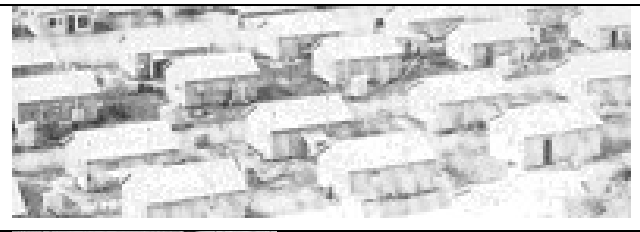 & 1967-69 & 93 & $\begin{array}{l}\text { Corrugated } \\
\text { iron, pitched }\end{array}$ & $\begin{array}{l}\text { Infra-red } \\
\text { heating, an } \\
\text { electric light, } \\
\text { power point, } \\
\text { chest of } \\
\text { drawers, table, } \\
\text { chair and bed }\end{array}$ \\
\hline Twizel & hI & 1969-84 & 112 & $\begin{array}{l}\text { Corrugated } \\
\text { iron, pitchec }\end{array}$ & $\begin{array}{l}\text { Bed, table chair, } \\
\text { clothes storage, } \\
\text { "rangette". The } \\
\text { first huts to have } \\
\text { porches. }\end{array}$ \\
\hline
\end{tabular}

Table 9: Comparison of singlemens huts 


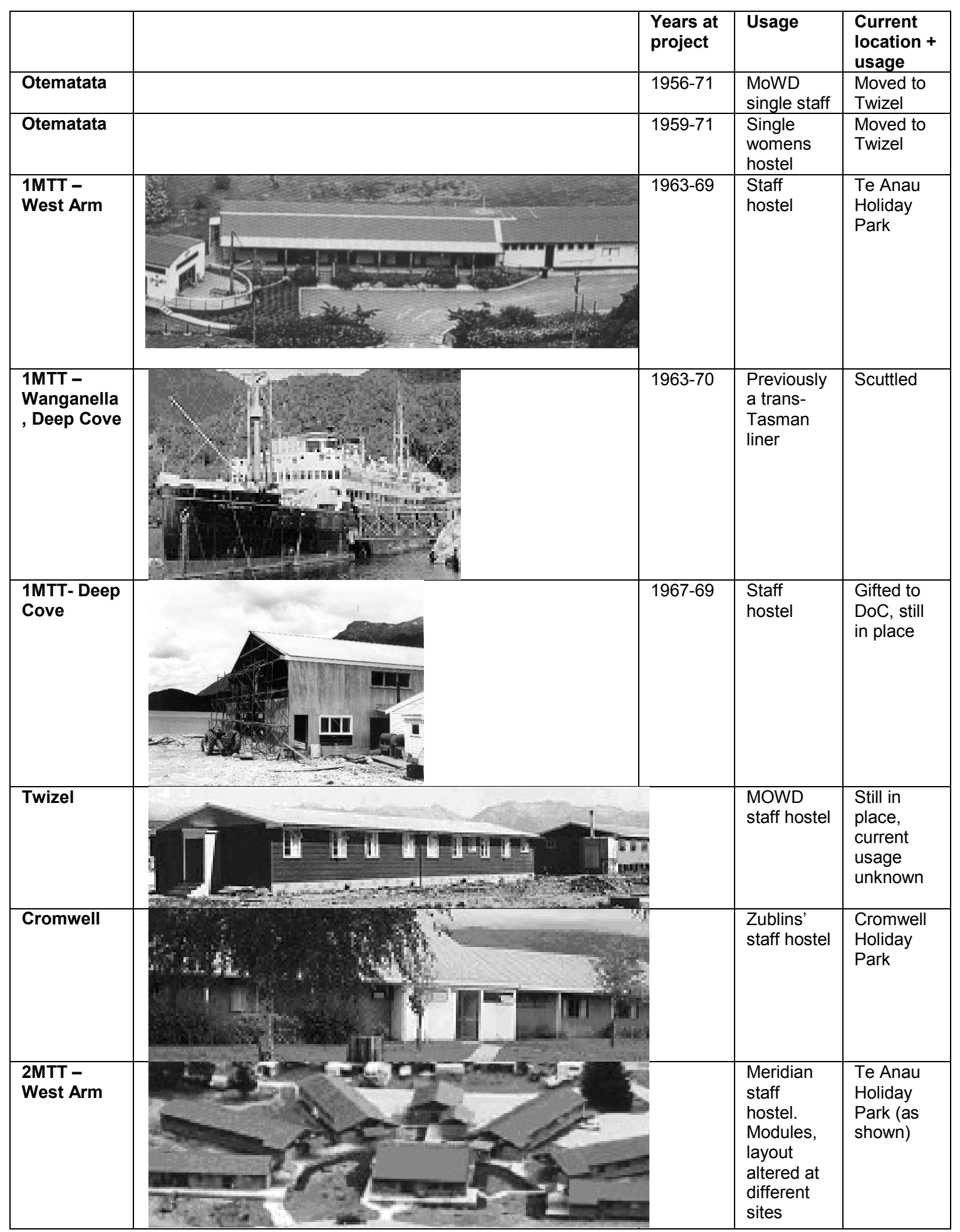

Table 10: Comparison of hostels

There seem to be several major elements which dictate the use of huts and hostels in the hydro camps, which have become apparent as this study has progressed. Certain conditions seem to dictate the necessary use of either, such as: 
- A need to preserve the environment $=$ hostels (foot traffic can be controlled more easily by use of walkways and the footings of hostels can be engineered to leave a smaller footprint than multiple huts would, eg: 2MTT)

- Uneven terrain = huts (the smaller footprint of a hut is less likely to require excavation or fill than a hostel, eg: Roxburgh)

- Extreme weather $=$ hostels (workers are more protected and often do not need to go outside to travel between bathrooms, bedrooms and relaxation areas, eg: 2MTT)

- Access difficulties $=$ huts (smaller and thus easier to transport, eg: 1MTT)

This is by no means an exhaustive list, nor is it meant to reflect strict rules, as can be seen at 2MTT, when the huts that were used for 1MTT were rejected in favour of hostels as priorities had changed over time. It is also interesting to note that it has most often been state run works which have provided huts (which have later been transferred to another project) and private enterprise which have provided hostels (which are often sold off after the initial project which they were supplied for).

In contrast to the list above there are also the community issues to be taken into consideration (see Community chapter for discussion of this).

The hostels show a split in design between those that are predominantly aimed at providing affordable accommodation and those that place an emphasis on making as little an impact on the local environment as possible. This split does not seem to affect transportability of the hostels.

The design of transportable huts and hostels in the region seems to be strongly biased towards using a system of prefabricated modules. This leaning has followed the designs through the entire history of hydro accommodation in the region, in comparison to designs of the same time period and similar functions in other parts of the world. Contemporary international examples show that transportable design for similar purposes in other parts of the world use several different types of construction to promote transportability, including flat pack, tensile and pneumatic, all of which have been overlooked in the local 
history of hydro accommodation (excluding the tents provided prior to Waitaki, which were a form of tensile structure).

In many developed countries where temporary accommodation is in use for isolated construction (and mining) projects, accommodation regulations form a part of the federal or state requirements for occupation. These can vary greatly in how prescriptive they are. For example, the Western Australia Construction Camp Regulations $(2004)^{162}$, gives minimum requirements for aspects such as volume of air space in sleeping quarters and amount of space to be provided at dining tables.

While this level of detail makes the accommodation requirements very clear (and assessment of the accommodation standards straightforward) it requires more consistency in site conditions than occurs in $\mathrm{NZ}^{163}$.

While there are elements such as site protection, geography and climate which point towards the use of huts or hostels, the huge variation in these site conditions throughout NZ ensure that each accommodation site requires individual assessment for the type of accommodation provision.

\footnotetext{
162 Appendix I

${ }^{163}$ For example, see the differences between Deep Cove and Twizel
} 


\section{Community}

Le Corbusier stated, in 1927, that "it is essential to create the right state of mind for living in mass-production houses ${ }^{164 "}$. He is still correct to this day, as these camps have shown.

In order to create this "right state of mind" a sense of community is vital. In order to assure this, impact assessments need to be made before a camp is set up and a relocation action plan is also advised by international best practice ${ }^{165}$. While these may not have been necessary for the majority of the camps studied in this thesis, today's camps are much more unlikely to occur in remote enough regions that the surrounding townships will be relatively unaffected.

During the planning phase alone, these camps (and the abandoned Project Aqua) have shown that local property and accommodation prices will escalate rapidly and, by introducing those already living in the area to the possibility of financial gain from renting accommodation in their houses, a positive aspect to the project can be introduced early on in the planning stage.

The sense of community within the camp is also highly affected by where the workers and the specialists come from, where in the camp they will be located and what sort of accommodation is provided.

The communities in the camps studied have all faced rapid growth and decline, a low proportion of elderly and a high proportion of dependent children, a much larger proportion of males in the population than females and a larger proportion of wage workers per head of population than that of the average community in New Zealand. To add to this, there has been a higher turnover in workforce than in other industries and very low employment rates for women. Often the children have left the community to study or find work once they have completed secondary school.

All of these factors have combined to create communities of which there are few to compare and often families have migrated from one camp to another as old projects finished and new ones started.

\footnotetext{
${ }^{164}$ Le Corbusier, p 245

165 Taylor et al "Social Assessment of Hydro-Electricity Development" p 3
} 
These camps have also provided bonus recreational and social opportunities for those living in local townships or rural areas who have benefited from the community facilities in the hydro townships.

In Waitaki, Roxburgh, Otematata and Twizel in particular, the house location, social status and position at work were all strongly linked (for example, singlemens accommodation was separated geographically from married housing and wage workers housing was segregated from staff housing). The social stratification of these towns was immense and when the projects ended the towns which continued to exist did so in a very different social manner to how they had operated as a camp. This, combined with newcomers attracted by the low cost housing who were often from low socio-economic backgrounds (or those who purchased houses to use as holiday homes), vastly reduced the community cohesion in the early days of "independence".

For these reasons it should be acknowledged how strong the sense of community had to be for Otematata and then Twizel to continue to exist when they passed into District Council control.

Today's technology means that most projects require much fewer staff and wage workers and are often achieved in much shorter time frames and, as a result of this, we are unlikely to ever see a repeat of the retention of massproduced 'transportable' houses on this scale in New Zealand.

Nick Taylor, Gerard Fitzgerald and Wayne McClintock have written two papers investigating the social impacts of hydro projects in $\mathrm{NZ}^{166}$, comparing the experiences of several hydro towns. Their main findings were as follows:

\section{"Demographic Patterns}

- Rapid population growth, averaging $15 \%$ over three years or more

- Sudden decline in population after the construction workforce peak had been reached

- A preponderance of males over females

- A relatively low proportion of elderly residents and a relatively large proportion of dependent children

\section{Construction Workforce}

\footnotetext{
${ }^{166}$ Nick Taylor, Gerard Fitzgerald and Wayne McClintock, "Resource Community Formation and Change in New Zealand" and

"Social Assessment of Hydro-Electricity Development: Lessons from the New Zealand Experience"
} 
- High turnover rates in construction workforces compared with national averages

- Migration between successive construction projects (eg: from Otematata to Twizel to Cromwell)

- During construction, an occupational structure dominated by males employed in blue collar jobs, and few employment opportunities for women; and after wind down significant changes as new industries and employment opportunities emerge

Housing

- A gradual improvement in housing over time between projects - from the tents used before the second world war, to temporary dwellings not designed to outlast the project in the 1960s, and ultimately to better quality houses for families in the 1970s and 80s

- Changes in settlement pattern - from different types of housing for staff and wage workers located in segregated areas in the earlier hydro towns, to higher quality dwellings of staff members dispersed throughout the settlement in later projects such as Turangi and Cromwell

- Accommodation provided rent-free or for a low payment

Local Services and Amenities

- Provision of all local services and amenities by the Ministry of Works (MOWD) in hydro towns built and owned by the government (ie:

Mangakino and Twizel), along with the establishment of welfare associations to manage community amenities in the absence of an official local authority

Community Identity

- The creation of a unique community identity due to the relative isolation of the settlements from the rest of the region and their single economic purpose

- The sense of community linked to the patterns of work associated with hydro construction activities and schedules and with the challenge of establishing local services and amenities

- The major role of a wide range of organized leisure activities and clubs in fostering social solidarity 
- Social and human capital continuity between successive hydro construction projects and their host communities, including transfer of leadership skills and relationships associated with community organizations

\section{Disadvantaged Groups}

- Disadvantage of some groups due to the special character of hydro towns

- Limited job opportunities for women, and inadequate childcare facilities

- Lack of recreational activities and employment for young people, with many moving to the cities for further education or careers

- In some North Island projects, pressure on local Maori tribes and their traditional way of life due to loss of land and the introduction of urban values by incoming workers

Wind Down

- Rapid decline in population as construction activity wound down

- The sale and removal of shops and houses out of the town and a decline in the local and regional economies due to loss of the income from construction workers

- Difficulties in physically and financially sustaining physical infrastructure and services designed for a finite life and for a much larger population

- Temporary, purpose-built towns (eg: Twizel) which managed to survive experienced more severe wind down effects than those that were planned to be permanent (eg: Turangi) or attached to an existing town (eg: Cromwell)"167

The findings of this study closely mirror the investigations made in this thesis. In particular, the community identity section identifies the issues of community identity and cohesiveness which are investigated in this section.

While social impact assessments for the region are now regarded as an important step in the formation of a hydro town (and often a requirement under resource consent guidelines), there has been an increasing step away from interaction with the local community in the more remote projects. For example, 2MTT had "relatively little social and economic impact on the township since it

${ }^{167}$ Taylor, Fitzgerald and McClintock, 2004, pp 5-6 
involved workers commuting long distance [sic] from homes outside the district to the site deep inside the Fiordland National Park and being accommodated on site $^{\text {,168 }}$. This shows clearly one evolution of large hydro projects away from forming townships and towards forming high intensity working communities, located remotely from families and external social distractions. This strain of development has become more popular as machinery becomes more effective and thus projects become shorter, with less manpower required and transportation and communications allow workers to keep closer contact with more distant families than previously.

When the 2MTT project came to completion, the local communities were not affected as badly as many of the communities surrounding hydro projects in the past. The end of the projects did not involve massive loss of local income, providing, instead, upgraded tourist facilities in the region (especially the Wilmot Pass Road from West Arm to Deep Cove, a more attractive West Arm site and an upgraded ferry service from Manapouri).

In contrast, the handover of Twizel from MoWD control and support to the MacKenzie District Council and private ownership of homes had a massive impact on the local community. There was an influx of newcomers of low socioeconomic status, drawn by the low housing prices, many support services and community facilities previously financially supported by MoWD were forced to close and unemployment increased greatly ${ }^{169}$. The community cohesion was lost and the great economic expectations of Twizel becoming the main rural service centre was not realised.

Twizel, while remaining physically intact, was a new township community-wise and the formation of the new community has taken much longer than envisaged as the new population had very little in common (unlike the hydro township population). This example clearly illustrates one of the conclusions of the 2004 paper by Taylor, Fitzgerald and McClintock ${ }^{170}$, that "most of the social and economic benefits from the development of hydroelectricity power schemes are derived at the regional and national levels, and these... developments often contribute little to the longer-term economic welfare of residual hydro town and

\footnotetext{
168 ibid, p8

169 ibid, p10

170 ibid p11
} 
existing rural communities". Therefore, social impact assessments are very important at the planning level and should be projected through to the postconstruction phase, when the greatest benefits can be gleaned from them.

Another important lesson from the study of the hydro towns and their communities is the large difference between communities in the state run and private enterprise projects. Often the social welfare of the community during a project has been taken into account by the MoWD (although not always successfully, it was usually well considered), but not so often by the private enterprises.

At Roxburgh, W. R. Burch noted ${ }^{171}$ that, after the MoWD handed over the project to the Anglo-Swiss consortium, the consortium began to fail because .." they gave little attention to developing a sense of social solidarity", in comparison to how the project had been run by the MoWD.

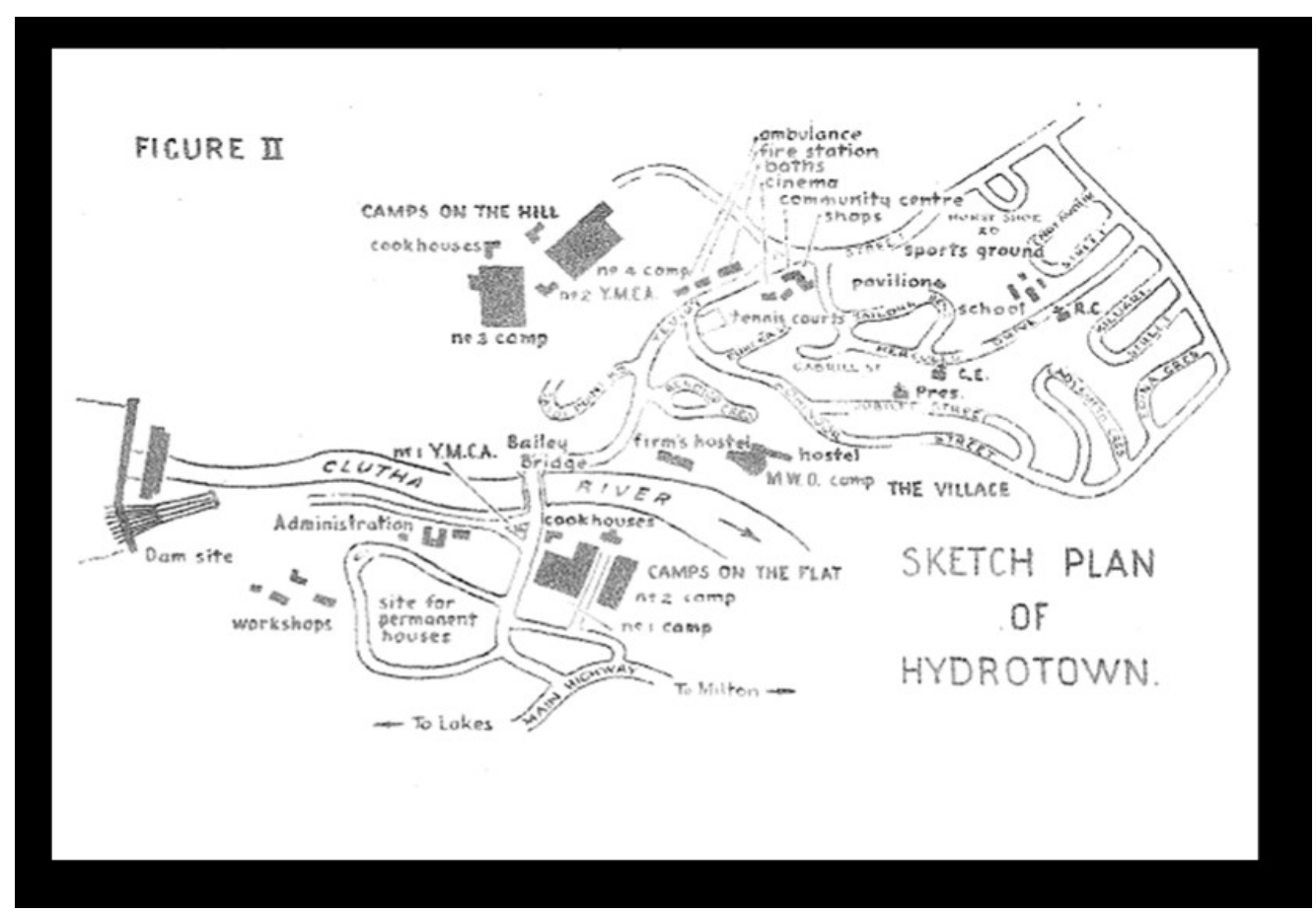

Figure 60: Roxburgh town plan

(diagram from Campbell, p126)

The MoWD had separated the township at Roxburgh into two distinct portions - the married and the single. The married portion of the township contained the

${ }^{171}$ Burch, pp85-6 
shops and the majority of community facilities and social clubs, with some playing fields and little else (other than huts, hostels, YMCA recreational centre and mess halls) in the single portion (leading to the single workers referring to themselves as the "forgotten race" ${ }^{172}$ ).

"The recreational facilities for the men in the Camps [ie: the single portion] were certainly inadequate, and this contributed to the turnover rate. Opinion was divided on the issue of making liquor available within the settlement, but there was nothing controversial about the need to provide more home comforts within the YMCA Huts, and to encourage visiting artists to entertain there. Geographically, the Village [ie: the married portion] and the Camps were close together, but socially they were miles apart, and the clubs which were organized mainly by the married people attracted few of the "forgotten race ${ }^{\text {ग17 } 73}$

Another, exacerbating, factor was the huge number of immigrants employed on this project. It was a time of huge immigration into NZ of many different nationalities post-WWII and it was an unusual experience for the New Zealand hydro workers to be vastly outnumbered by other nationalities.

The various nationalities grouped themselves into neighbouring huts, creating their own communities and isolating themselves from neighbouring communities. Often, this meant that, if the group was large enough, members of the national community did not socialize with anyone of another nationality, creating vast rifts in the community as a whole, which was overlooked by the private enterprise consortium running the project ${ }^{174}$. As the community became more divided, the understanding of each other lessened and communications broke down.

While assimilation may have been too optimistic, the inclusion of social integration measures in the project plan may well have reduced the high rate of staff turnover. Campbell noted that “...attempts might have been made to encourage more interaction within the Village and Camps by preventing the formation of isolated groups, preserving a separate identity. The Dutch in Camp 2 were the best example of this. They spoke their own language, to a large extent cooked their own meals, and had a minimum of contact with other nationalities.

\footnotetext{
${ }^{172}$ Campbell, p8

${ }_{174}^{173}$ Campbell, p86

174 ibid, p88 "...some segregation was evident within the Camps, but there was never any managerial policy on the matter"
} 
They even disowned their own members who married New Zealand girls and lived in the Village." 175

The lack of community cohesion made communication difficult and was part of the reason that jobs became no longer allocated on abilities (which were not commonly known amongst the work crews as they no longer communicated effectively), but merely on the luck of the draw. What was seen by the workers as a lack of acknowledgment of their individual capabilities by the management translated into dissatisfaction with their jobs and further heightened the rate of employee turnover and, thus, productivity on site.

Roxburgh, of course, is not the only example of the direct link which can be drawn between the importance of community cohesion and the success of the project. However, Roxburgh is a rather extreme example of the danger in neglecting the social needs of the hydro town, with an international conglomerate having the project removed from their management as it began to fail.

Private enterprise seems to be more susceptible to ignoring the importance of community cohesion, most probably as a lack of recognition of the link between social solidarity and worker performance (and, thus, financial gain for the head contractor), and history has shown that foreign companies are the worst. The author has been told in various conversations with ex-hydro workers about resentment created towards the giant German company of Ed Zublin at Cromwell when a worker broke his leg and was moved aside so work could continue, only to lie on the side of the track for some time waiting for an ambulance while work was expected to continue around him. Further resentment was created by Zublins when the senior management encouraged the workers to join them in celebrating Adolf Hitler's birthday.

At both of the camps working on 1MTT, the predominantly Kiwi workers had a hard time getting used to what they perceived as dictatorial management methods of the Americans ${ }^{176}$. This was exacerbated by the isolation of the workers in three separate locations (1MTT was a more remote project than the 2MTT project because of the separation of the sites prior to the completion of the Wilmot Pass Road in 1965) -

\footnotetext{
${ }^{175}$ ibid, p117

${ }^{176}$ L Hutchins, p94
} 
- Deep Cove: the Wanganella was moored here, providing accommodation for 464 men, but it was not directly accessible from the shore for the first 17 months of the project, requiring launch access. There were eventually 64 rooms in the staff hostel on shore and 103 singlemens huts. Residents here were shipped in to site through Doubtful Sound prior to construction of the Wilmot Pass Road, making access to the outside world weather dependent and a lengthy process.

- West Arm: several hundred workers were housed here in singlemens huts and a staff hostel. Residents here were able to access the town of Manapouri via a ferry.

- Manapouri: 249 houses provided accommodation for workers and their families. These houses were on the mainland

In other sectors of the hydro town communities (in most camps) there was also social isolation caused by the lack of jobs for women, which made it difficult for women to meet others, and by the lack of childcare, which meant that nights out were few and far between for parents ${ }^{177}$, which thus affected their ability to socialise.

Thus, while a sense of community was important to production levels, there were several sectors of the population who were overlooked in the social planning of the hydro towns and there were also several examples of contractors who did not recognize the importance of community formation.

${ }^{177}$ W J Campbell, pp51-2 


\section{Cost}

It is interesting to note that many people who turn their noses up at state housing, referring to it as "cookie cutter", "institutionalised", etc, do not seem to have the same preconceptions about Twizel. Twizel is today seen as a valid holiday destination. In fact, when the housing at Twizel was sold, a number of the new residents were state house tenants who chose to give up their state provided housing for the opportunity to own their own house (thus choosing to pay off a mortgage rather than pay subsidised rent and to adopt upkeep issues as their own in order to move to a home which was exactly like hundreds of its neighbours rather than just like half a dozen of its neighbours, as is the state house context).

Tenants who remained on in Otematata and Twizel adopted their homes, very rarely moving into a different house when the time came to purchase the houses (except in some forced examples at Otematata where half the town was removed), despite the fact that any number of the houses for sale may have the identical layout to theirs but may, in fact, be in better condition or a better location.

The remainder of residents who purchased houses in these towns did so because they were cheap. Quite a few purchases were made with the intention of realising a large profit in a short time by on-selling the house. Others who purchased because they were cheap saw these houses as holiday accommodation.

It seems very few people saw the price of these homes as a reflection of the expected lifespan of the buildings and services, but more of a reflection that cost had been reduced through mass production. Many of these houses are still standing with a very small proportion actually replaced. Money has, however, been invested in upgrading the buildings and in individualising them ${ }^{178}$.

To consider in this section is also the question of whether the free housing (in the later towns, a small rent was charged) had anything to do with drawing workers to the hydro towns. WJ Campbell noted that he heard many comments in Roxburgh about the great upgrading of accommodation from tents to timber huts

\footnotetext{
${ }^{178}$ See Appendix D - Otematata and Appendix F-Twizel
} 
and houses and how much easier this had made the job ${ }^{179}$. In the post-WWII years Roxburgh would have appeared very attractive with its upgraded accommodation, compared to the great housing shortage in the remainder of the country.

Colin Knight conducted interviews at Twizel and Otematata and recorded the following:

"Mr Brian Thompson, a Ministry of Works building inspector at Twizel, began life in a hydro-town twenty years ago at Roxburgh. When asked why he chose to live and work away from the main centers of New Zealand in remote areas where the climate is often harsh, he said, "During my time I have lived and not just existed. By this I mean that unlike most chaps my age (he is married with five children) I have been able to afford to do what I have wanted to. I have not been tied down to a mortgage and a strict budget, although of course we do budget.

"I have, for example, been able to buy the sort of car I wanted and we have also been able to take trips away."180

So, while the cost of the housing may have acted to lessen the community cohesion once the hydro projects were completed, by drawing in people from many different backgrounds and regions, during construction it drew in workers and the community formation planning (particularly that by the state) acted to draw these people into a cohesive community of sorts.

\footnotetext{
${ }^{179}$ W J Campbell, p49

180 Knight, p 33
} 


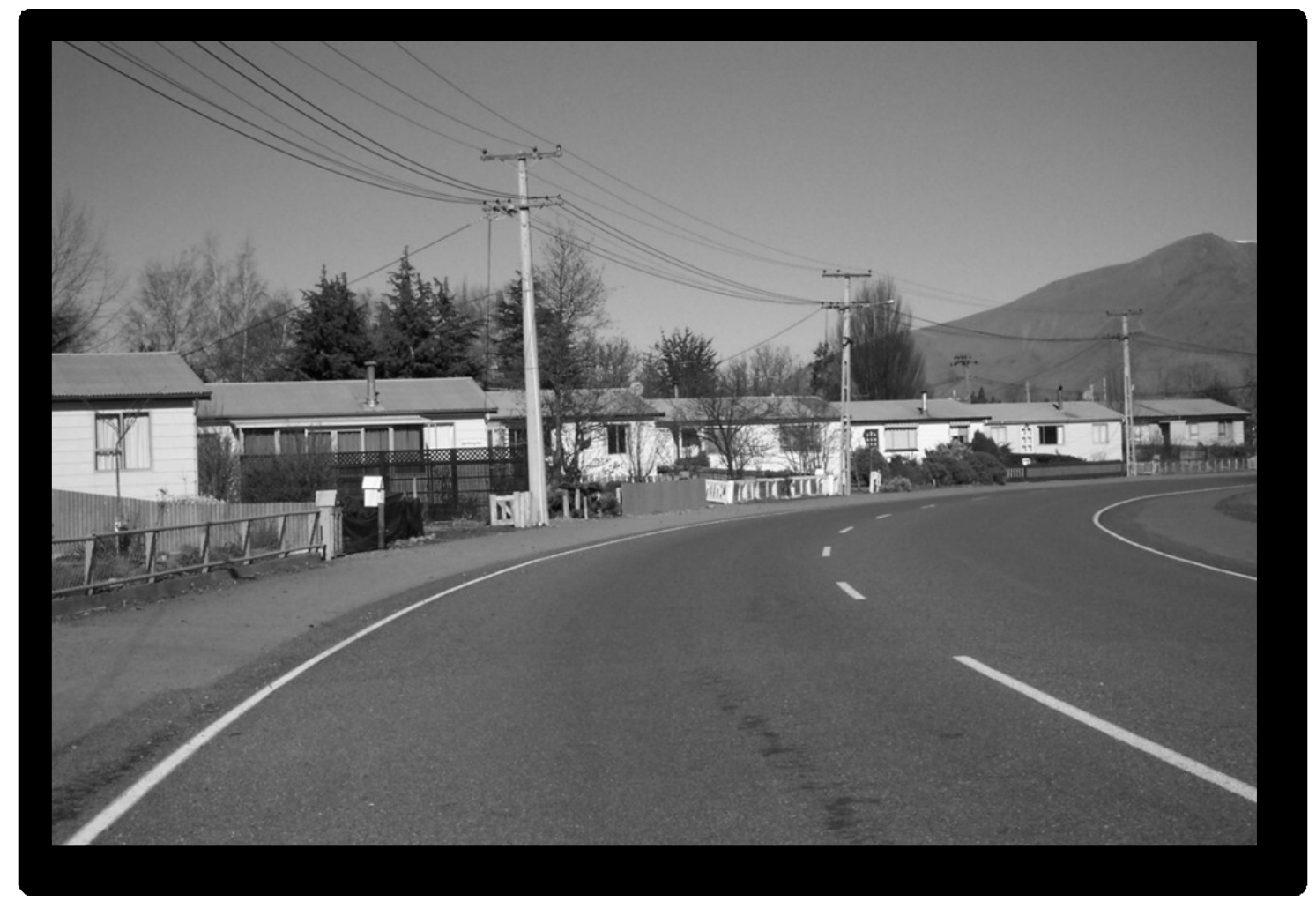

Figure 61: Streetscape, Twizel, 2005 


\begin{tabular}{|c|c|c|c|c|c|}
\hline & & $\begin{array}{l}\text { Cultural } \\
\text { diversity }\end{array}$ & $\begin{array}{c}\text { Social } \\
\text { stratification }\end{array}$ & $\begin{array}{c}\text { Social } \\
\text { facilities }\end{array}$ & $\begin{array}{l}\text { Community } \\
\text { push for } \\
\text { retention }\end{array}$ \\
\hline WAITAKI & & Little & $\begin{array}{c}\text { Yes - } \\
\text { although } \\
\text { mitigated by } \\
\text { depression }\end{array}$ & $\begin{array}{c}\text { Centred } \\
\text { around } \\
\text { YMCA - } \\
\text { travel limited }\end{array}$ & No \\
\hline ROXBURGH & & $\begin{array}{c}\text { A lot from } \\
\text { immigrants } \\
\text { and } \\
\text { consortium }\end{array}$ & Yes & $\begin{array}{l}\text { Multiple as } \\
\text { set up to be } \\
\text { a model } \\
\text { town }\end{array}$ & No \\
\hline OTEMATATA & & $\mathrm{A}$ lot ${ }^{181}$ & Yes & $\begin{array}{l}\text { Multiple as } \\
\text { set up to be } \\
\text { a model } \\
\text { town }\end{array}$ & Yes \\
\hline \multirow[t]{3}{*}{ 1MTT } & West Arm & A lot & No & $\begin{array}{l}\text { Limited to } \\
\text { camp }\end{array}$ & No \\
\hline & $\begin{array}{l}\text { Deep } \\
\text { Cove }\end{array}$ & A lot & No & $\begin{array}{l}\text { Limited to } \\
\text { camp }\end{array}$ & No \\
\hline & Manapouri & Some & No & $\begin{array}{c}\text { Some, } \\
\text { mostly } \\
\text { shared with } \\
\text { local } \\
\text { community }\end{array}$ & No \\
\hline TWIZEL & & Some & Yes & $\begin{array}{l}\text { Multiple as } \\
\text { set up to be } \\
\text { a model } \\
\text { town }\end{array}$ & Yes \\
\hline CROMWELL & & Some & Yes & $\begin{array}{l}\text { Shared with } \\
\text { local } \\
\text { community }\end{array}$ & Permanent \\
\hline 2MTT & West Arm & Some & No & $\begin{array}{l}\text { Limited to } \\
\text { camp }\end{array}$ & No \\
\hline
\end{tabular}

Table 11: Community assessment of hydro towns

Cultural diversity: This was predominantly an issue in the singlemens camps. It was affected by large numbers of immigrants post-WWII, the government's immigration policies and the inclusion of overseas companies in consortiums submitting tender bids. Cultural diversity in all cases studied caused increased community diffusion.

Social stratification: This was predominantly an issue in the housing (ie: married and family) sections of the hydro towns. close working conditions (and the allocation of houses to senior staff) reduced the amount of social stratification amount the men and this was most easily visible in the singlemens camps. In the

\footnotetext{
181 "One day I said I want to go on a language bloody course because I had so many foreigners in my gang. I think I only had two Kiwis in the gang of 15 or 16 . There were White Russians, Yugoslavs, everybody; even had an Aussie" Jones, p 10
} 
housing areas the inclusion of families created conditions in which the social norms of the 'outside world' were more closely adhered to.

Social facilities: Where multiple social facilities were provided within the hydro town or camp, community cohesion appears to have been stronger. Multiple social facilities were provided at the towns which were to remain in place the longest and where families were encouraged to join the workers in accommodations. Both factors (length of project and family inclusion) are also strong factors in creating community cohesion, so this cannot be solely attributed to the number of social facilities, despite the interrelationship of the elements.

Retention: In this thesis, the petitioning of the occupying community to retain the housing is taken as the ultimate measure of occupant satisfaction in the housing. Occupant satisfaction in accommodations is a major element in the reduction of staff turnover rates. However, desire for retention is unable to be used as a measure of occupant satisfaction in huts and hostels due to the nomadic nature of the singlemen workers at the hydro projects (ie: their primary motivation was financial and the project was unable to offer them long-term satisfaction in terms of marriage, family, career, stability, etc). 


\section{CHAPTER FOUR: CONCLUSION}


Environmental conditions (geography, climate, vegetation, slope, etc), mixed with increasing private vehicle ownership and the endless search for greater occupant comfort led to accommodation sites being located further from project sites and an increased amount of houses (as opposed to huts and hostels) through the progression of the case studies. It is only where the environmental conditions prohibit that there is any deviation from a direct evolution, based on these aspects, from Waitaki through to Cromwell.

The extremities of the climatic conditions experienced in these camps and towns were responded to with additions and alterations which not only affected transportability, but also improved occupant comfort in the houses to the extent that the residents petitioned to retain the 'temporary' houses at both Otematata and Twizel, ignoring the original intentions of the housing.

The design and layout of any type of the accommodation did not allow for visual or fire separation until the NZBC and permanent standards were brought to bear on the designs at Cromwell and 2MTT. Some separation had been provided in the housing areas of earlier hydrotowns, where individual sites promoted this, but often garages, huts and additions were added to the site and reduced the separation.

The population of the hydrotowns consisted of more men that women, more young than old and all with a single purpose. The entire town was owned and run by a single entity (the MoWD). These conditions typically promote a strong sense of community, particularly when coupled with a layout derived from the Garden City model (designed to promote community cohesion).

However, the MoWD policy of segregation between the accommodation areas for married and single workers was continued by the private enterprise consortiums which contributed to the projects, despite affecting community cohesion. Through all of the case studies, the housing for the accompanied workers in the hydrotowns was kept distinctly separated from the huts and hostels of the singlemens camps.

In any future large scale mass produced housing projects in this region, social impact assessments and community planning are essential in order to determine the needs of the workers so that a cohesive community may be formed.

Expression of individualisation is an important part of sense of community as it ensures that each person feels unique, yet part of a whole. 
Individualisation of the houses did not become important to the residents while they were occupied by a single purpose community with no individual ownership (except in a negative manner when some tenants chose not to maintain the houses and their surrounds) until Otematata. Where the workforce was in occupation for over ten years, and materials were readily available, individualisation began prior to wind-down of the project and shows a level of occupant satisfaction with the housing which predicts a resident-driven request for retention.

Individualisation became very important when individual ownership and a democratic, varied community took over. Many houses were altered to express the owners' individuality, directly reflecting the change in communities.

The extent of the transformation research has been limited by the records available. Further investigation into the contractors providing services in Otematata and Twizel after the houses were sold into private ownership and the affordability of their services would greatly improve the understanding of individualisation as it would most probably clarify the options which were available to the owners.

An early move away from transportable tensile structures to transportable modular units was never challenged, primarily because the modular units allowed ease of alteration and additions. However, the upgrading of houses eventually led to large modules which had the possibility of outstripping both the ease of transportability and the short intended (15 years) lifespan of the materials at the time of construction were rapidly forgotten at every case study, with additions and alterations severely affecting both of these integral aspects. This dichotomy was finally concluded by the construction of permanent houses at Cromwell.

Many large infrastructure and mining projects in other developed countries have had to abide by strict regulations determining design of accommodations, but projects in NZ have largely been self-regulating until the NZBC was applied to Cromwell and 2MTT. Self-regulation has not been completely effective, evidenced by the post-construction additions and alterations which both ignored and negated the design intentions of transportability and short lifespan of the materials.

The length of the project also seems to have a large effect on the choice of camp type to consider. If the permanent housing option is chosen and families 
are included in the camp then this will suit a longer term project than a shorter term project. At the end of a longer term project it is also more likely that the families will wish to remain in the accommodation and thought can be given in early project budgeting for considering offering housing purchase schemes in the salary packages and thus allowing the accommodation to be largely selffinancing during the construction programme and project rather than carrying the debt through to the project conclusion.

The design of the houses, huts and hostels took 30 years to erase the early difference in standards between state rental housing and workers accommodation. As time progressed, the house designs began to multiply and the standards improve, providing more comfortable accommodation for all occupants and culminating in occupant-led retention proposals at both Otematata and Twizel, and permanent housing at Cromwell. Yet, in contrast, industrialisation has also reduced the necessary workforces and projects in remote areas (such as 2MTT) are now choosing to provide accommodation for the workers only and not their families.

It is easy to draw the conclusion that the permanent housing supplied at Cromwell was a natural progression of hydro villages in the south. However, by doing so one is ignoring the environmental concerns raised in relation to $2 \mathrm{MTT}$. It is therefore obvious that large scale works camps in remote areas in the south have now been split into two camps - to retain as an answer to the critical affordable housing shortage in many parts of the region or to 'touch the earth lightly' and protect and repair the environment.

Clearly, partners and families are only welcome in the first option and any camps trying to comply with the second option need to include transportation for workers to leave the area during days off and preferably start considering this at the design stage rather than as an afterthought.

The future of isolated infrastructure projects and the accommodation provided at them now rests in the hands of private enterprise with application of NZBC requirements (the MoWD was abolished in 1988).

The function of accommodations can sometimes be defined by permanent neighbourhoods adjoining existing towns, but where this is not possible (ie: isolated sites), accommodations require flexibility in regulations in order to meet 
the demands of environmental conditions, temporary structures and transportability.

Regulations such as those from Western Australia ${ }^{182}$ are strongly prescriptive and this level of design restrictions may not be applicable to a country such as NZ with extremes of environmental conditions of every type which may all need to be addressed by the same legislation. Further research is needed to determine such guidelines as may be applicable to future infrastructure construction camps and single purpose towns in NZ.

${ }^{182}$ See Appendix I - Western Australian Construction Camp Regulations 


\section{BIBLIOGRAPHY}

- Abalos, Inaki and Herreros, Juan, "Construction and Housing: a Possible Decalogue" in Housing: New Alternatives in Quaderns, 1995

- Alexander, Christopher, et al, A Pattern Language, New York: Oxford University Press, 1977

- Architecture for Humanity (ed), Design Like You Give a Damn: Architectural Responses to Humanitarian Crises, London: Thames and Hudson, 2006

- Arieff, Allison, Prefab, Utah: Gibbs Smith, 2002

- Bassett, Keith and Short, John, Housing and Residential Structure: Alternative Approaches, London: Routledge and Kegan Paul, 1980

- Belich, James, Paradise Reforged: A History of the New Zealanders from the 1880s to the Year 2000, Auckland: Penguin Books (NZ), 2001

- Bell, Bryan (ed), Good Deeds, Good Design: Community Service Through Architecture, New York: Princeton Architectural Press, 2004

- Bennett, Scott, TSMV Wanganella History, November 2002

- Bergdoll, Barry and Christensen, Peter, Home Delivery: Fabricating the Modern Dwelling, New York: The Museum of Modern Art, 2008

- Building Research Establishment, BRE Digest: Relocatable Buildings: Structural Design, Construction and Maintenance, UK: Digest 374, August 1992

- Burch, W. R., "The Nature of Community and a Case Analysis of Failure" in Forster, John (ed), Social Process in New Zealand: Readings in Sociology, Auckland: Longman Paul, 1969

- Burnett, John, Social History of Housing 1815-1970, England: David and Charles, 1978

- Campbell, W. J., Hydrotown: The Social History of an Industrial Boom Settlement, Dunedin: University of Otago, 1957

- Chandler, Peter M. and Hall, Ron C., Let There Be Light...A History of Bullendale and the Generation of Electric Power in Central Otago, Alexandra: Otago Central Electric Power Board, 1986

- Chapple, Geoff, "Deep and Singing Silences" in Welch, Dennis (ed), Places:....From the Pages of the New Zealand Listener, Auckland: Random House New Zealand, 2005

- Conroy, Brian, "Mobile Homes - A Viable Alternative?" in People and Planning, vol 1, no 17, March 1981

- Davies, Colin, The Prefabricated Home, London: Reaktion Books, 2005

- Davis, J, "Disaster Housing: A case study of Managua" in Architectural Design, vol 45, no. 1, 1975

- Dawson, Graham, "Prefabricated Houses" in The Journal of the New Zealand Institute of Architects, Vol 19, No 5, June 1952. Pp 75-6

- DTZ Research, Housing Costs and Affordability in New Zealand, Wellington: CHRANZ, 2004

- Edwards, Kate, "State Houses and Proud of Them" in New Zealand Heritage, Issue 89, Winter 2003. Pp 26-9

- Ferguson, Gael, Building the New Zealand Dream, Palmerston North: Dunmore Press, 1994 
- Firth, Cedric, State Housing in New Zealand, Wellington: Ministry of Works, 1949

- Fitzgerald, Gerard, "A Case Study of Manapouri", Working Paper 21, Resource Community Formation and Change, Christchurch: Taylor Baines and Associates, September 2000

- Fitzgerald, Gerard, Taylor, Nick and McClintock, Wayne, "the Impacts of Resource Sector Restructuring on Occupational and Community Identity", paper prepared for the Annual Meeting of the International Association for Impact Assessment, Den Haag, The Netherlands, 17-21 June 2002

- Fowler, Michael, "The Case Against New Towns", in People and Planning, Vol 1, No 3, June 1977. Pp23-5

- Gatley, Julia, "Labour Takes Command: A History and Analysis of State Rental Flats in New Zealand 1935-49" submitted in fulfilment of the requirements for the degree of Master of Architecture, Victoria University of Wellington, 1997

- Gausa, Manuel, Housing: New Alternatives, New Systems, (translated by Paul Hammond) Barcelona: Actar, 1998

- Gibb, Alistair G F, Off-Site Fabrication: Prefabrication, Pre-Assembly and Modularisation, Scotland: Whittles Publishing, 1999

- Glen, Frank, Holy Joe's People: A Parson in Fiordland, Wellington: AH and AW Reed, 1968

- Granger, JM, Mobile Domestic Architecture, University of Sydney: Ian Buchan Fell Research Project on Housing, July 1970

- Groak, S, Bottom, D, Gann, D and Meikle, J, Innovation in Japanese Prefabricated House Building Industries, Department of Trade and Industry OSTM visit report, CIRIA SP139, England: Construction Industry Research and Information Association, 1996

- Groat, Linda and Wang, David, Architectural Research Methods, New York: John Wiley and Sons, 2002

- Hasman, Cynthia, Mangakino in Perspective, Turangi: Tongariro Welfare Association, 1976

- Herbers, Jill, Prefab Modern, New York: Harper Design International, 2004

- Herbert, Gilbert, The Dream of the Factory-Made House: Walter Gropius and Konrad Wachsmann, Massachusetts: MIT Press, 1984

- Higham, J.R.S. and Austin, J., Regional Resource Development: the Local Impact of the Upper Clutha Scheme, with Respect to Transport, Employment, Housing and Commercial Activity, Otago: Resource Development Unit of Business Development Centre, University of Otago, 1980

- Holthouse, Simon, The Mobile Home in Australia: Its Potential Role in the Housing and Recreational Environment, Canberra: The Royal Australian Institute of Architects, 1975

- Howard, George, The Heart of Fiordland, Christchurch: Whitcombe and Tombs, 1966

- Howard, George, Power from Fiordland, Wellington: Department of Education, 1972

- Hutchins, Les, Making Waves, Queenstown: Les Hutchins, 1998

- The Institution of Structural Engineers, Temporary Demountable Structures: Guidance on design, procurement and use (Second Edition), London: SETO, 1999 
- Joint Planning Committee, Cromwell Town Expansion Report January 1975, Wellington: Whitcoulls, 1975

- Jones, Lloyd, Benmore, Wellington: Cycoda Limited, 2005

- Kahn, Lloyd, Home Work: Handbuilt Shelter, California: Shelter Publications, 2004

- Kennedy, Joseph F. (ed), Building Without Borders: Sustainable Construction for the Global Village, B.C., Canada: New Society Publishers, 2004

- King, Peter, Private Dwelling: Contemplating the Use of Housing, London: Routledge, 2004

- Knight, Colin, Hydro-towns/Nomadic Communities: Waitaki Basin Power Project, Wellington: Reed Education, 1972

- "The New Towns" in

- Knox, Ray, "The New Towns" in New Zealand's Heritage: The Making of a Nation, Wellington: Paul Hamlyn, 1971-3. Pp2529-2537

- Kramer, John (ed), North American Suburbs: Politics, Diversity and Change, Berkeley: The Glendessary Press, 1972

- Kronenburg, Robert, Houses in Motion: The Genesis, History and Development of the Portable Building, London: Academy Editions, 1995

- Kronenburg, Robert, Portable Architecture, Oxford: Architectural Press, 2000

- Kronenburg, Robert, Spirit of the Machine: Technology as an Inspiration in Architectural Design, Chichester: Wiley-Academy, 2001

- Kronenburg, Robert (ed), Transportable Environments: Theory, Context, Design and Technology, London: E and F N Spoon, 1998

- Kronenburg, Robert, Lim, Joseph and Chii, Wong Yunn (eds), Transportable Environments 2, London: Spon Press, 2003

- Leach, Andrew, Frederick H. Newman: Lectures on Architecture, Belgium: A\&S/books, 2003

- Leach, Andrew, "Power Architecture: Reading the Architecture of Electricity" a thesis submitted in fulfiment of the requirements for the degree of Master of Architecture, Victoria University of Wellington, Wellington, New Zealand, December 1999

- Le Corbusier, Towards a New Architecture, (translated by F. Etchells) London: The Architectural Press, 1985

- Linzey, Kate, "Making a Place: Mangakino 1946-62" from "From over-sweet cake to wholemeal bread": the Home and Building Years :New Zealand Architecture in the 1940s a one day symposium, pp 60-3

- MacFadyen, Dugald, Sir Ebenezer Howard and the Town Planning Movement, Manchester: Manchester University Press, 1970

- Macy, Christine and Bonnemaison, Sarah, Architecture and Nature: Creating the American Landscape, London: Routledge, 2003

- Martin, John E. (ed.), People, Politics and Power Stations : Electric Power Generation in New Zealand 1880-1990, Wellington: Bridget Williams Books and the Electricity Corporation of New Zealand, 1991

- Martin, Lewis E., Built for Us: the Work of Government and Colonial Architects, 1860s to 1960s, Dunedin: University of Otago Press, 2004

- Maxwell, James, Discovering the New Mackenzie and Waitaki Valley Country, Tekapo: Homecrafts, 1980 
- McCarthy, Christine, "Partial Architecture: Post World War II New Zealand Government Housing" in Fabrications - The Journal of the Society of Architectural Historians, Vol 13, No 1, June 2003. Pp 33-51

- Mcelroy, Elissa J., "An Analysis of Planning Procedures Associated with the Development of the Cromwell Town Plan", dissertation in partial fulfilment of post-graduate Diploma in Regional and Resource Planning, University of Otago, Dunedin, 1982

- McLintock, A. H., The History of Otago: The Origins and Growth of a Wakefield Class Settlement, New Zealand: Otago Centennial Historical Publications, 1949

- Meridian Energy, "Manapouri: Working with the Environment", June 2004

- Meridian Energy, "Project Aqua: Resource Consent Applications and Notice of Requirements", May 2003 (CD-rom)

- Meridian Energy, "Second Manapouri Tailrace Tunnel: Construction Report", December 2002

- Meridian Energy, "Technology and Teamwork: The Second Tailrace Tunnel, Manapouri Power Station", 2002

- Milne, Christopher D. A. (ed.), Handbook of Environmental Law, Wellington: Royal Forest and Bird Protection Society of New Zealand, 1992

- Ministry of Civil Defence, Civil Defence in New Zealand: A Short History, Wellington: Ministry of Civil Defence, 1990

- Ministry of Works, Department of Housing Construction, State Housing in New Zealand: Foundation and Development of the Department of Housing Construction, Wellington: Ministry of Works, Department of Housing Construction, 1943

- Mitchell, David and Chaplin, Gillian, The Elegant Shed: New Zealand Architecture Since 1945, Auckland: Oxford University Press, 1984

- Moen, R. M. (District Planner), "Report on Concept for Temporary Twizel Housing, Cromwell Borough", dated 06/03/81

- Natusch, G. G., Waitaki Dammed and the Origins of Social Security, Dunedin: Otago Heritage Books, 1984

- Newman, Frederick H., "Architecture in Hydro Design" in The Journal of the New Zealand Institute of Architects, Vol 26, No 3, April 1959. Pp 71-81

- Newman, Frederick H., "Social Factors in Architecture and Their Implications for New Zealand" in The Journal of the New Zealand Institute of Architects, Vol 19, No 6, July 1952 and Vol 19, No 7, August 1952. Pp 85-109

- Newman, Frederick H., "The Interrelation of Engineering Design and Architecture" in The Journal of the New Zealand Institute of Architects, Vol 18, No 6, July 1951. Pp 93-108

- Noonan, Rosslyn J, By Design: A Brief History of the Public Works Department Ministry of Works 1870-1970, Wellington: Government Printer, 1975

- O'Brien, Gregory, "The Importance of Being Ernst" in New Zealand Heritage, Issue 94, Spring 2004. Pp 16-7

- Offer, R.E., Walls for Water: Pioneering Dam Building in New Zealand, Palmerston North: Dunmore Press, 1997

- Olssen, Erik, A History of Otago, Dunedin: John Mclndoe, 1984

- Otematata Welfare Association, Benmore, Otematata: Otematata Welfare Association, 1963 
- Ozkan, Suha, "Turkey: Foam Domes" in MIMAR, vol 8, 1983

- Pattie, Marjorie, "Mangahao Power Station" in New Zealand Memories, Issue 57, December/January 2006. Pp 28-9

- Peart, Raewyn, The Community Guide to the Resource Management Act 1991, Auckland: Environmental Defense Society, 2004

- Peat, Neville, Detours: A Journey Through Small-Town New Zealand, Christchurch: Whitcoulls Publishers, 1982

- Peat, Neville, Manapouri Saved! New Zealand's First Great Conservation Success Story, Dunedin: Longacre Press, 1994

- Ponder, W Frank, A Man From The Ministry: Tales of a New Zealand Architect, Christchurch: The Caxton Press, 1996

- Porter, George, unpublished article in Davis, Kenneth, "A Liberal Turn of Mind: The Architectural Work of F. Gordon Wilson 1936-59" presented in partial fulfilment of the requirement undertaken at Victoria University of Wellington for the degree of Bachelor of Architecture at the University of Auckland, 1987

- Queensland Government, Workers Accommodation Act 1952

- Rennie, Neal, Power to the People: 100 Years of Public Electricity Supply in New Zealand, Wellington: Electricity Supply Association of New Zealand, 1989

- Schrader, Ben, We Call It Home: A History of State Housing in New Zealand, Auckland: Reed Publishers, 2005

- Schwartz-Clauss, Mathias (curator), Living in Motion: Design and Architecture for Flexible Dwelling (exhibition catalogue), Weil am Rhein: Vitra Design Museum, 2002

- Scoates, Christopher (ed), LOT-EK: Mobile Dwelling Unit, New York: DAP/Distributed Art Publishers, 2003

- Scottish Office Building Directorate, A Guide to Non-Traditional and Temporary Housing in Scotland 1923-55, Edinburgh: Her Majesty's Stationery Office, 1987

- Shaw, Peter, A History of New Zealand Housing, Auckland: Hodder Moa Beckett Publishers, 1997

- Sheridan, Marion, Dam Dwellers: End of an Era, Twizel: Sheridan Press, 1995

- Siegal, Jennifer (ed), Mobile: The Art of Portable Architecture, New York: Princeton Architectural Press, 2002

- SKOR (Foundation for Art and Public Space), Parasite Paradise: A Manifesto for Temporary Architecture and Flexible Urbanism, Rotterdam: NAi Publishers, 2003

- Smith, Courtenay and Topham, Sean, Xtreme Houses, Munich: Prestel, 2002

- Sorrell, Peter (ed), The Cyclopedia of Otago and Southland, Dunedin: Dunedin City Council, 1999 (2 volumes)

- Soules, Gordon, The Housing Crisis: Causes Effects Solutions, Vancouver: Gordon Soules Economic and Marketing Research, 1976

- Stevenson, Greg, Palaces for the People / Prefabs in Post-War Britain, London: B T Batsford, 2003

- Stolz, H. J. and Warren, F. T., Construction of the Manapouri Tailrace Tunnel and Wilmot Pass Road: Completion Report, Invercargill: Utah-WilliamsonBurnett (Joint Venture), October 1969 
- Taylor, Nick, Fitzgerald, Gerard and McClintock, Wayne, "A Case Study of Twizel", Working Paper 22, Resource Community Formation and Change, Christchurch: Taylor Baines and Associates, 2000

- Taylor, Nick, Fitzgerald, Gerard and McClintock, Wayne, "Resource Community Formation and Change in New Zealand", Christchurch: Taylor Baines and Associates, 2001

- Taylor, Nick, Fitzgerald, Gerard and McClintock, Wayne, "Social Assessment of Hydro-electricity Development: Lessons from the New Zealand Experience", paper prepared for the Annual Meeting of the International Association for Impact Assessment, Vancouver, 26-29 July, 2004

- Tiege, Karel, The Minimum Dwelling, translated by Eric Dluhosch, Massachusetts: MIT Press, 2002

- Tipple, Graham A., Self Help Transformations of Low Cost Housing: An Introductory Study, Newcastle upon Tyne: Centre for Architectural Research and Development Overseas in association with International Urban Press, 1991

- Toomath, William, Built in New Zealand: The Houses We Live In, Auckland: HarperCollins, 1996

- Topham, Sean, Move House, Munich: Prestel Verlag, 2004

- Toy, Maggie (ed), Architectural Design Profile 135: Ephemeral/Portable Architecture, London: Vol 68 No 9/10 September/October 1998

- UN Habitat, Roles, Responsibilities and Capabilities for the Management of Human Settlements: Recent Trends and Future Prospects, Nairobi: UN Habitat, 1990

- Venturi, Robert, Scott Brown, Denise and Izenour, Steven, Learning From Las Vegas, Massachusetts: MIT Press, 1972

- Vernon, Jan, "Lake Pukaki Memories" in New Zealand Memories, Issue 57, December/January 2006. Pp 46-51

- Vulker, Judy and MacDonald, Gillian, Architecture in the Wild: The Issues of Tourist Developments for Remote and Sensitive Environments, Canberra: RAIA National Education Division, 1989

- Wallis, Allan D, Wheel Estate: The Rise and Decline of Mobile Homes, New York: Oxford University Press, 1991

- White, R B, Prefabrication: A History of its Development in Great Britain, London: Her Majesty's Stationery Office, 1965

- Williams, Anita, "take it or leave it?" in Vogue Living, July/August 2006. Pp 789

- Williamson, Paul, "An Analysis of New Zealand's First Government Sponsored Housing Scheme" submitted in partial fulfillment of the requirements of the Bachelor of Architecture degree, Victoria University of Wellington, 1988

- Wilson, Gordon F, "Lessons in Prefabrication" in NZ Financial Times, March 1943. P139 


\section{WEBSITES}

- www.archidose.org/Feb02/020402.html Future Shack

- www.abc.net.au

- www.bbc.co.uk

- www.bestpractices.org Best Practices Database

- www.bayerchemicals.com Bayer Chemicals (Foam Domes)

- www.calearth.org

- www.cliflo.niwa.co.nz NZ climate data

- www.construction-manager.co.uk magazine of the Chartered Institute of Building (UK)

- $\quad$ www.design-museum.de Living in Motion exhibition

- www.economad.com

- www.fabprefab.com Modernist prefab dwellings

- www.gtj.org.uk

- www.imagesofengland.co.uk

- www.jipemtb.com

- www.manufacturedhousing.org

- www.meridianenergy.co.nz/ProjectAqua/news Project Aqua News

- www.mhousing.com

- www.modularcenter.com

- www.miningwatch.org Environmental Mining Council of British Columbia, Mining in Remote Areas: Issues and Impacts

- www.mthousing.net

- www.nucleus.com/ briggs Port-a-Fold

- www.prefabs.co.uk

- www.tba.co.nz Taylor Baines and Associates

- www.terrapin-Itd.co.uk

- www.time.com Time magazine

- www.un.org

- www.unchs.org

- www.unhcr.ch

- www.weatherhaven.com

- www.wikipedia.com 
APPENDICES 


\section{A: 1921 Public Works and Construction Workers Agreement}

\section{INTERIM RATES OF PAY}

Chuckman.

s.

Per hour

Concrete work - tunnel.

$21 \frac{1}{2}$

Concrete work - ordinary

$2 \quad 11 / 2$

Compressor - Head attendant

20

3

Compressor - Attendant.

$2 \quad 1 \frac{1}{2}$

Per week

Divers - horse, one

s. d.

Drivers - horse, two

$4 \quad 10$

$4 \quad 15$

Each additional horse $3 / 6$ per week

Fencer

s. d.

Foreman - tunnel 23 to 2

20

Foreman - concrete

$2 \quad 1 \frac{1}{2}$

Ganger- navvy....

2

Ganger - platelayer, tunnel

Ganger - platelayer..............................

Ganger - quarry....

Ganger - scoop

Labourer

Labourer - skilled

$101 / 2$

Lifters - line. 2

Machinemen - tunnel.

Machinemen - quarry.

3

Platelayer.

3

Powerhouse attendants

0

Quarryman

Rockman.

0

Shift Boss - tunnel

0

Shoveller - tunnel

3

Timberman and skilled tunneller.

Truckers

Waggoner

1

Per day

s. d.

Timekeeper.

WET PLACES

160

In all "wet places" six hours' work shall be considered a working day, and shall be paid for as if eight hours had been worked. The question of "wet places" to be agreed upon by Check Inspector and Engineer. 


\section{OVERTIME}

Except in "wet places", overtime at rate and one-half will be paid after $81 / 2$ hours have been worked on any one day, excepting Saturday, when overtime shall be paid after $41 / 2$ hours have been worked.

All time worked in "wet places" after six hours in any one day shall be paid for as rate and one-half, but no overtime work in "wet places" shall be permitted except in cases of extreme urgency.

\section{TRAVELLING TIME}

Travelling time, to be paid both ways, for men compelled to live more than one mile from the works, the basis where men walk to be 20 minutes to the mile. Where men, at their option, live further from the works than one mile, they are to be excluded from the preceding clause. Where men are conveyed to the work from depots by train, they shall be paid for travelling time at the daily rate. Fettlers travelling by velocipede to be paid for travelling time beyond that required to travel the first mile on a basis of $7 \frac{1}{2}$ minutes to the mile.

\section{SHIFTING TIME}

A reasonable allowance of time occupied in erecting tents or shirting camp shall be made and paid for at current rates. The Check Inspector and Engineer to interpret "a reasonable allowance of time".

\section{PROVISION OF TOOLS}

Shovels, picks, and axes required in the actual carrying out of the work shall be provided free: but their value shall be held by the Department until they are returned to the storekeeper.

\section{SLIPS AND WASH-AWAYS}

In case of emergency, where men are required to work long hours under adverse conditions, reasonable refreshments such as tea or coffee, and food, shall be provided at the expense of the Government.

\section{CO-OPERATIVE WORK}

Present co-operative system to continue.

\section{CO-OPERATIVE CONTRACTS}

The Resident Engineer or other responsible Government officer letting a cooperative contract shall prepare a plan and specification for such co-operative contract showing accurately the quantities of work contained in such contract, and shall fix a price to such quantities of work as will permit a fair average workman to earn a daily wage equal to the current rate of wages in the district in which the work is located.

When a co-operative contract is let, the Resident Engineer, or other Government officer letting the same, shall supply the co-operative contractor with a copy of the plans and specifications relating to the contract, and also a schedule of quantities and prices, signed by him, and shall also keep a copy of the contract plans, specifications, and schedule, signed by the co-operative contractor.

After a co-operative contract is signed, the quantities shall not be altered or carried unless the scope of work is definitely reduced or increased; but if the scheduled prices in the contract are found to be too high or too low, the Engineer or other officer in charge of the work may, after giving the co-operative contractors six clear days' notice in writing, reduce or increase such prices and fix them at such rate as will permit a fair average workman to earn a daily wage equal to the current rate of wages ruling in the district where the work is located, or the engineer or other officer in charge may, at his discretion, after giving the co-operative contractors six clear days' notice, terminate the contract. 
When the nature of the material encountered varies, the rate at which the new material is to be shifted shall be fixed at the earliest date possible, and the amended price shall cover all such material shifted whether before the fixing of the new price or subsequently.

Earthwork co-operative contracts for cuttings or embankments entailing long leads shall have the prices arranged on a graduated scale, according to the length of the lead, in order to safeguard against the contract being abandoned as the lead lengthens.

\section{PAYMENTS}

In cases of necessity, workmen may be allowed to draw 75 per cent of wages due, such payment to be made on a day to be nominated by the Department, but not before the expiration of the first fortnight, the Department only retaining money due between the time of measuring up and the actual pay day, same not to exceed six days' wages.

Retrospective from November 20, 1919

HOLIDAYS

From the above date workmen with over two months' continuous service, but under two years' continuous service, are entitled to the following holidays: - New Years' Day, Boxing Day, Good Friday, Easter Monday, Birthday of the Reigning Sovereign, Labour Day, and Christmas Day.

After two years' continuous service form $20^{\text {th }}$ November, 1919 , or any subsequent date, 14 days' annual leave plus two additional holidays will be allowed, viz., Dominion Day and Provincial Anniversary of Province. The beforementioned holidays, with the exception of Christmas and New Year's Day, may be accumulated and taken with the consent of the Engineer at the end of each year: Provided the workman informs the Engineer three days before the holiday of his intention to work on that day. Overtime shall not be allowed for any of the holidays on which an employee elects to work. Annual leave not to accumulate, and if not taken annually will be forfeited. Seven days' continuous absence from work, without leave, constitutes a break in service.

HORSE HIRE

The maximum rates for horse hire shall be as follows: -

8/- per day when oaten chaff at £8 per ton

$8 / 6$ per day when oaten chaff at $£ 9$ per ton

9/- per day when oaten chaff at $£ 10$ per ton

9/6 per day when oaten chaff at $£ 11$ per ton

$10 /$ - per day when oaten chaff at $£ 12$ per ton

$10 / 6$ per day when oaten chaff at $£ 13$ per ton

$11 /$ - per day when oaten chaff at $£ 14$ per ton

$11 / 6$ per day when oaten chaff at $£ 15$ per ton

$12 /$ - per day when oaten chaff at $£ 16$ per ton

Tip horse 1/- per day less than scale.

The suitability of the horses for the work to be decided by the Union and the Engineer.

UNDERGROUND VENTILATION

Ventilation to be subject to the requirements of the Mines Act as applicable to quartz and alluvial mining.

FIREWOOD AND FUEL

Department to provide fuel at cost price. HUT ACCOMMODATION 
Single men to be provided with $10 \mathrm{ft} . \mathrm{x} 8 \mathrm{ft}$. hut, suitable bunk and fireplace; married men without family to have hut with room $24 \mathrm{ft} . x 10 \mathrm{ft}$., plus a room $10 \mathrm{ft}$. $x$ 9ft. for use as kitchen. Married men with a family up to four children to have two rooms $24 \mathrm{ft}$. x $10 \mathrm{ft}$; for every additional two children, one $10 \mathrm{ft}$. $\mathrm{x} 8 \mathrm{ft}$. hut to be added.

Bathing facilities, wash-house and cooking range, also fireplace in living room to be provided. Mattress to be provided, the Union to be responsible for prevention of abuse of mattresses.

\section{TENTS MAY BE USED TEMPORARILY}

The use of tents will be restricted as much as possible on railway construction works, and where used shall be framed, and floored, and supplied with a limited amount of timber sidewalls, and provided with fireplace and chimney attached.

\section{RECREATION HALLS}

That where twenty or more men are to be employed on a job for twelve months or more, a recreation hall shall be erected and furnished with tables and chairs. The hall to be placed under the control of the Union.

\section{BATHS AND DRYING ROOMS}

On tunnel works, bathing conveniences with hot and cold water, as well as a drying room, shall be established, as already provided at Huarau, Waikiekie, and Otira.

\section{SANITATION}

That earth closers, with doors and seats and urinal attached, be provided, one for every six hutments; closets and urinals to be regularly disinfected, and when required, shall be removed by the Government.

\section{CLEANSING AND DISINFECTING}

Upon hutments becoming vacant, they shall be cleansed and disinfected before again being reinhabited, at the cost of the Government; but if the hut is let in an unreasonably dirty or damaged condition, the cost of renovations will be charged against the employee who vacated. If a man allocated to a hut considers the same not in proper order, he shall call the Overseer's attention thereto, and the question of his absence of liability to make good any damage shall be settled in advance.

\section{GOVERNMENT CANTEENS}

Department will establish canteens for the supply of provisions, etc., on such works as the Minister shall determine.

\section{GRIEVANCES}

Local Engineers shall have power to settle all reasonable grievances on the job with the accredited representative of the men concerned, but if such Engineer is of opinion that the dispute is beyond his authority, he and the Union representative shall each forward a statement to the local District Engineer for settlement. When all efforts of the District Engineer to effect a settlement have failed, then only shall the dispute be referred to Head Office.

Complaints direct from local representatives of the Union re disputes will not be recognized by the Minister of Head Office in the future.

\section{DURATION}

This agreement shall remain in operation until the thirtieth day of June, 1922, unless during the ensuing twelve months the Government finds it necessary to review the whole question of the payments to employees in the Public Service, of which the Union will have due notice.

\section{NOTICE}


This agreement, which slightly revises the original agreement between the Public Works Department and the New Zealand Workers' Union, has been submitted to the Minister of Public works and confirmed by him.

Wellington, June 26, 1921 


\section{B: Waitaki}

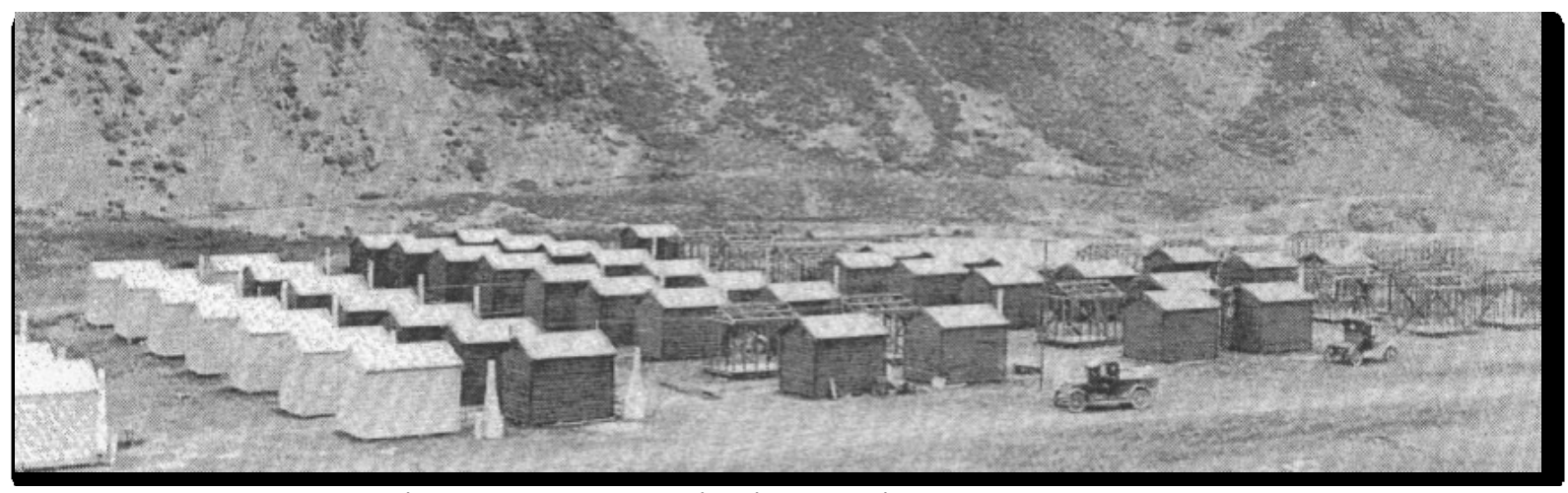

B1: Singlemens' huts, Waitaki hydro village, December 1928

(Electricity Division, Ministry of Energy, from Natusch, p11)

These huts are timber, with malthoid roofs and built on site. The chimneys preclude total transportability but, as can been seen here, the chimneys are not hard to remove. The minimal windows allowed for little ventilation or light. Natural light was further reduced by the close proximity of the huts, which also reduced acoustic and visual separation, while providing little protection from the spread of fire but providing some protection from the climate. By comparing these huts to the size of the vehicle it is possible to conclude that there was very little space inside these huts.

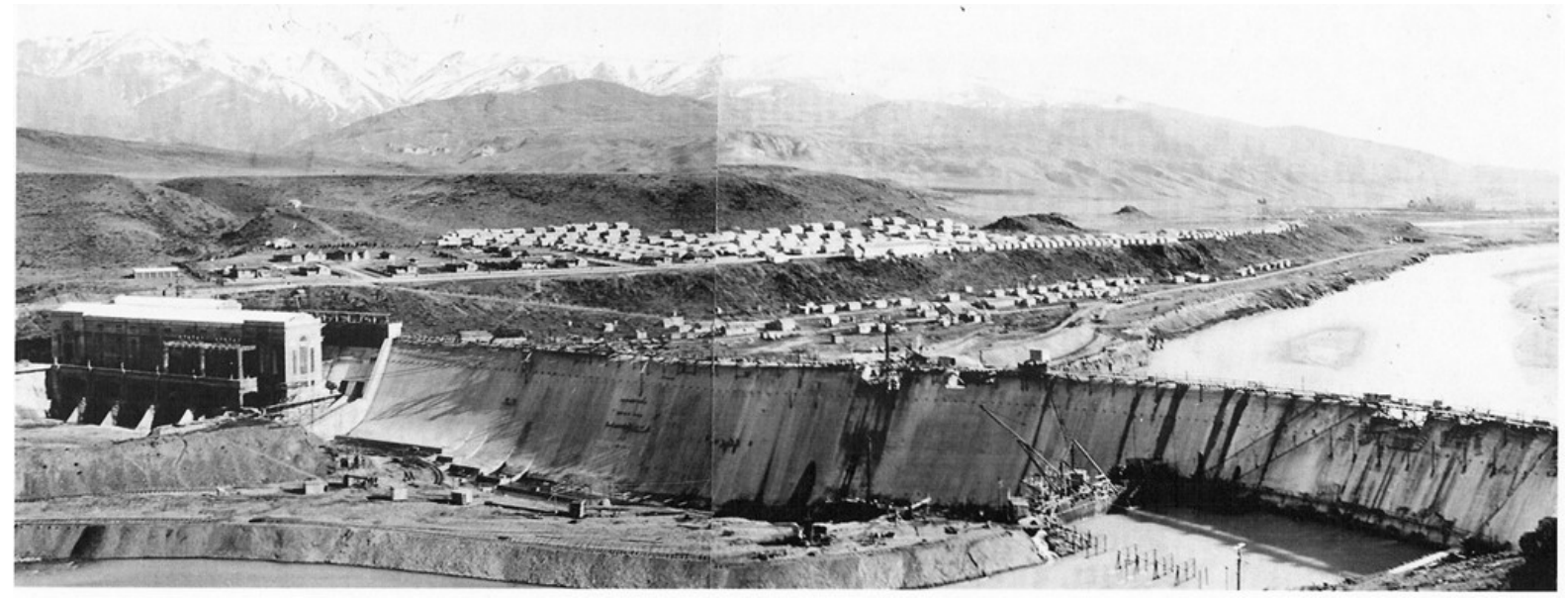

B2: Waitaki Hydro electric Station, nearly completed, 10 August 1934

(Evening Post Collection, Alexander Turnbull Library, Wellington, NZ. Ref \#: PICT-000087)

In this picture it is easy to see that there was not a lot of separation between family accommodation areas and single accommodations. The only clear separation is between the permanent concrete houses at the upper left and the other accommodations. 


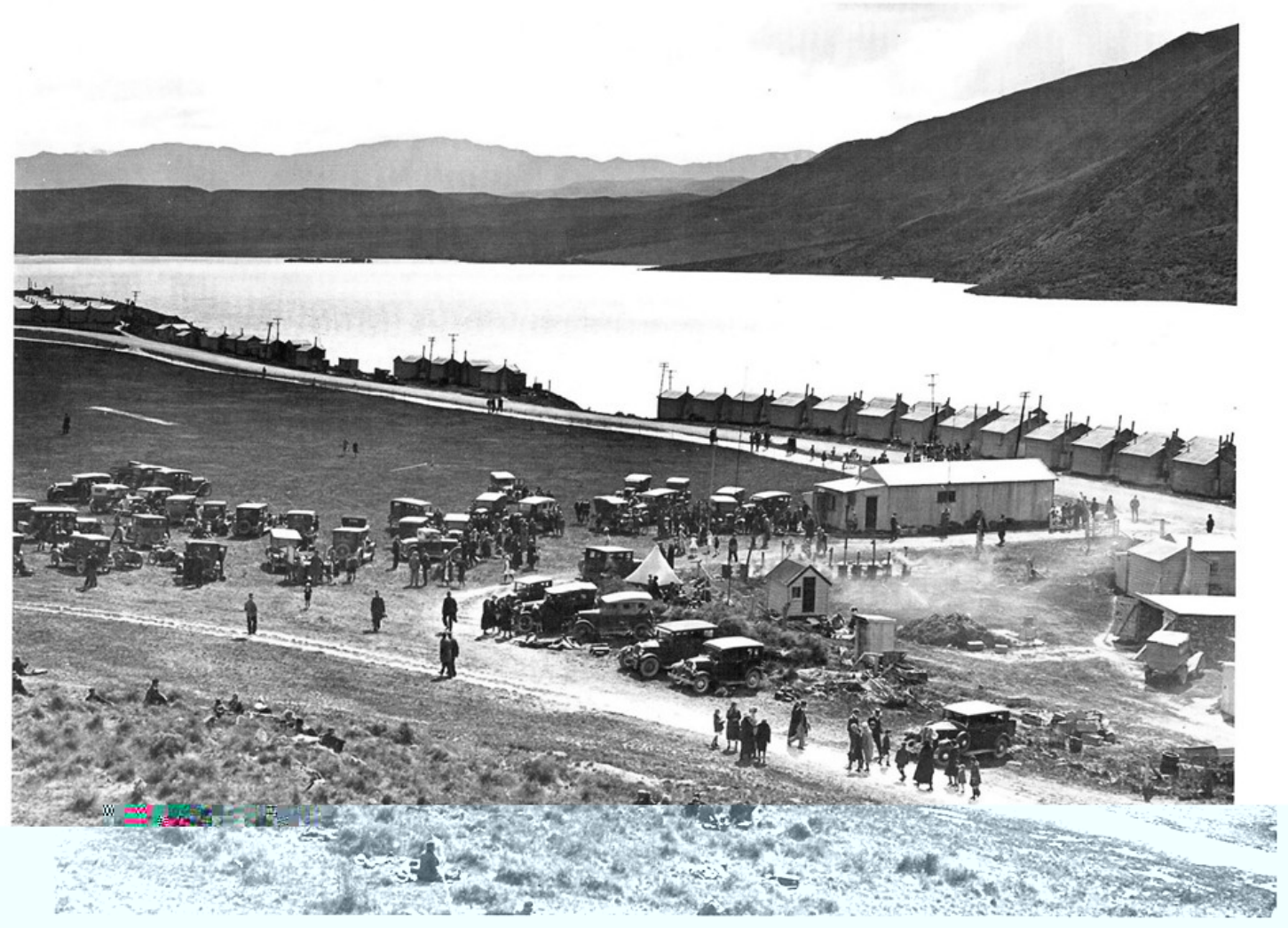

B3: Visitors at Waitaki Hydro dam on picnic day, 4 October 1934

(Evening Post Collection, Alexander Turnbull Library, Wellington, NZ. Ref \#: PICT-000086)

In this picture it is clear to see the separation between huts. While providing little in the way of protection from spread of fire or noise, their close proximity does provide some protection from the wind and frosts. 


\section{C: Roxburgh}

\section{间 - huts \\ VIA - houses}
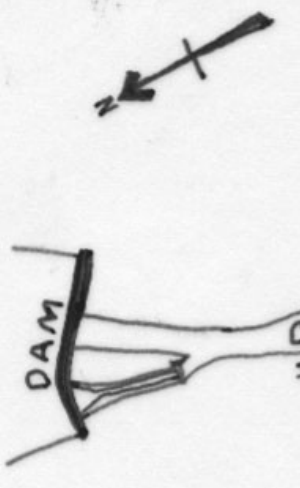


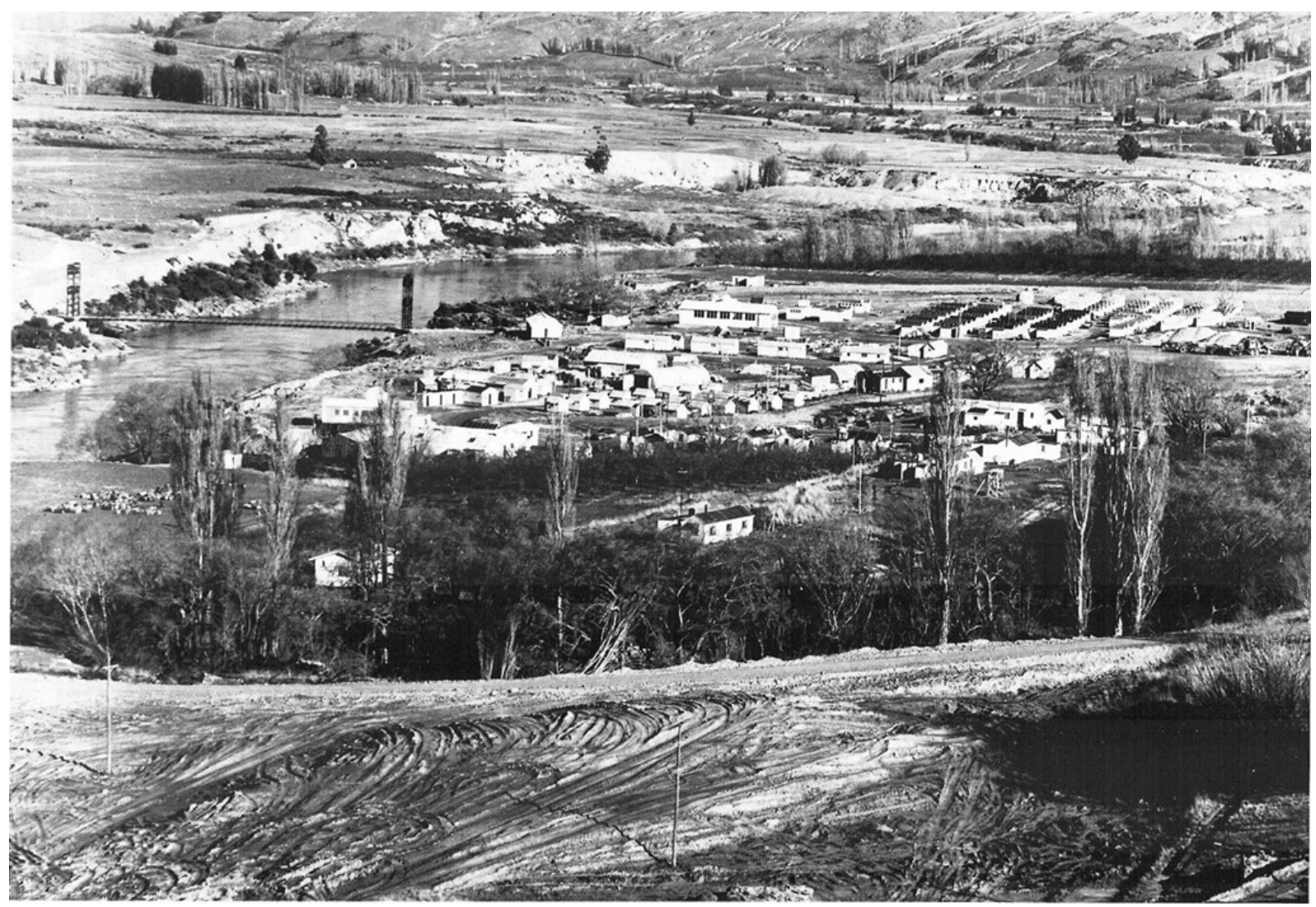

C2: A view of the camp at the hydro-electric works at Roxburgh gorge. The south end of the deviation is seen in the foreground and the Bailey bridge spanning the Molyneux is to the left, 21 September 1949

(Photographer: Jack Debnam Stewart Roberts. NZ Free Lance Collection, Alexander Turnbull Library, Wellington, NZ. Ref\#: C-1746-1/2)

This camp is quite similar to the one at Waitaki, particularly in the close proximity of the accommodations providing some protection from the climate, but little protection from fire or acoustics. 


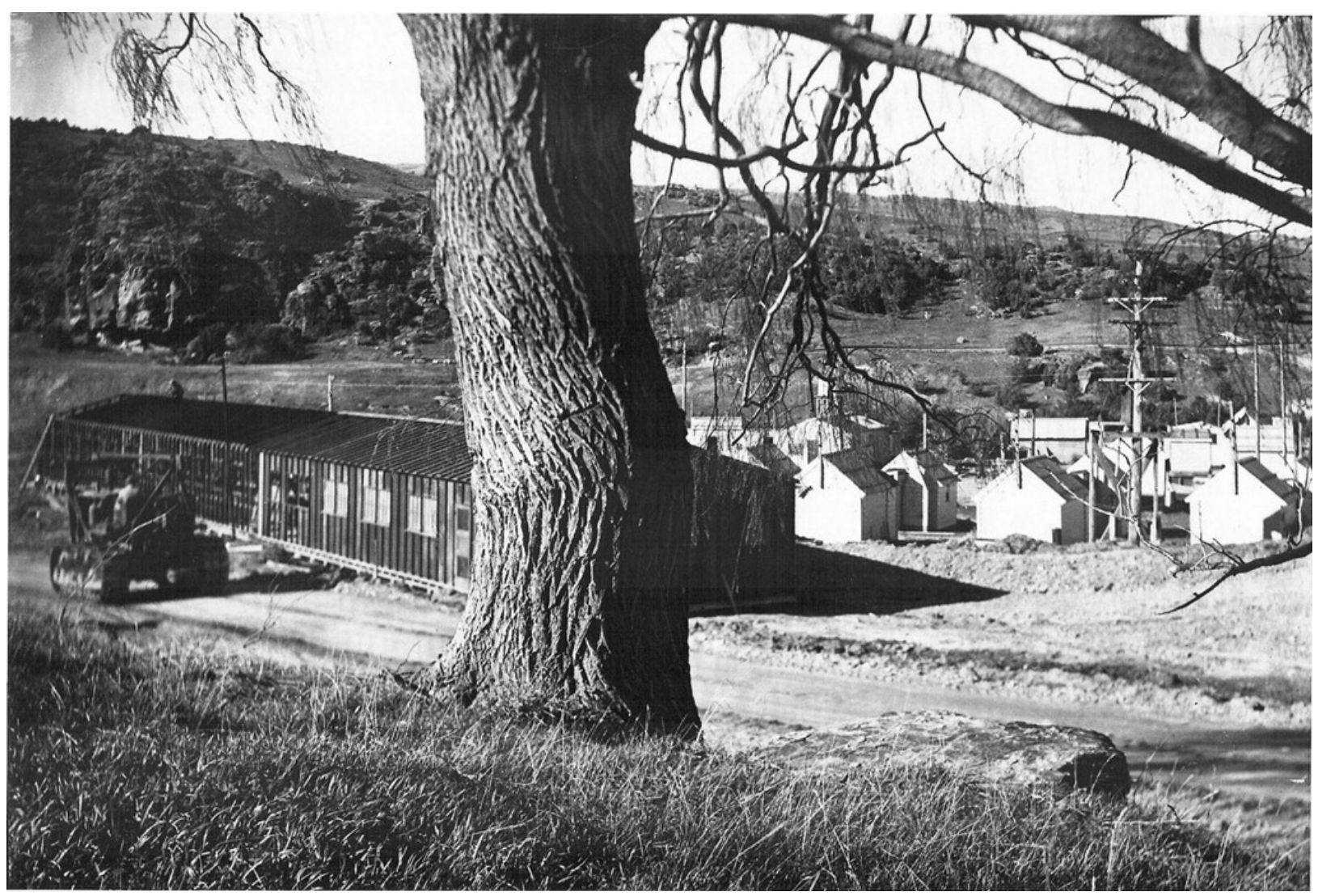

C3: The new block of administration offices being erected in the Roxburgh Hydro Camp. Some of the hutments are also visible.

(Photographer: Jack Debnam Stewart Roberts. NZ Free Lance Collection, Alexander Turnbull Library, Wellington, NZ. Ref\#: PICT-000088)

It is possible to see from this picture that there is a little more spacing between accommodations than at Waitaki in this area.

Also more easily visible here are the above ground electricity reticulation and the unsealed roads.

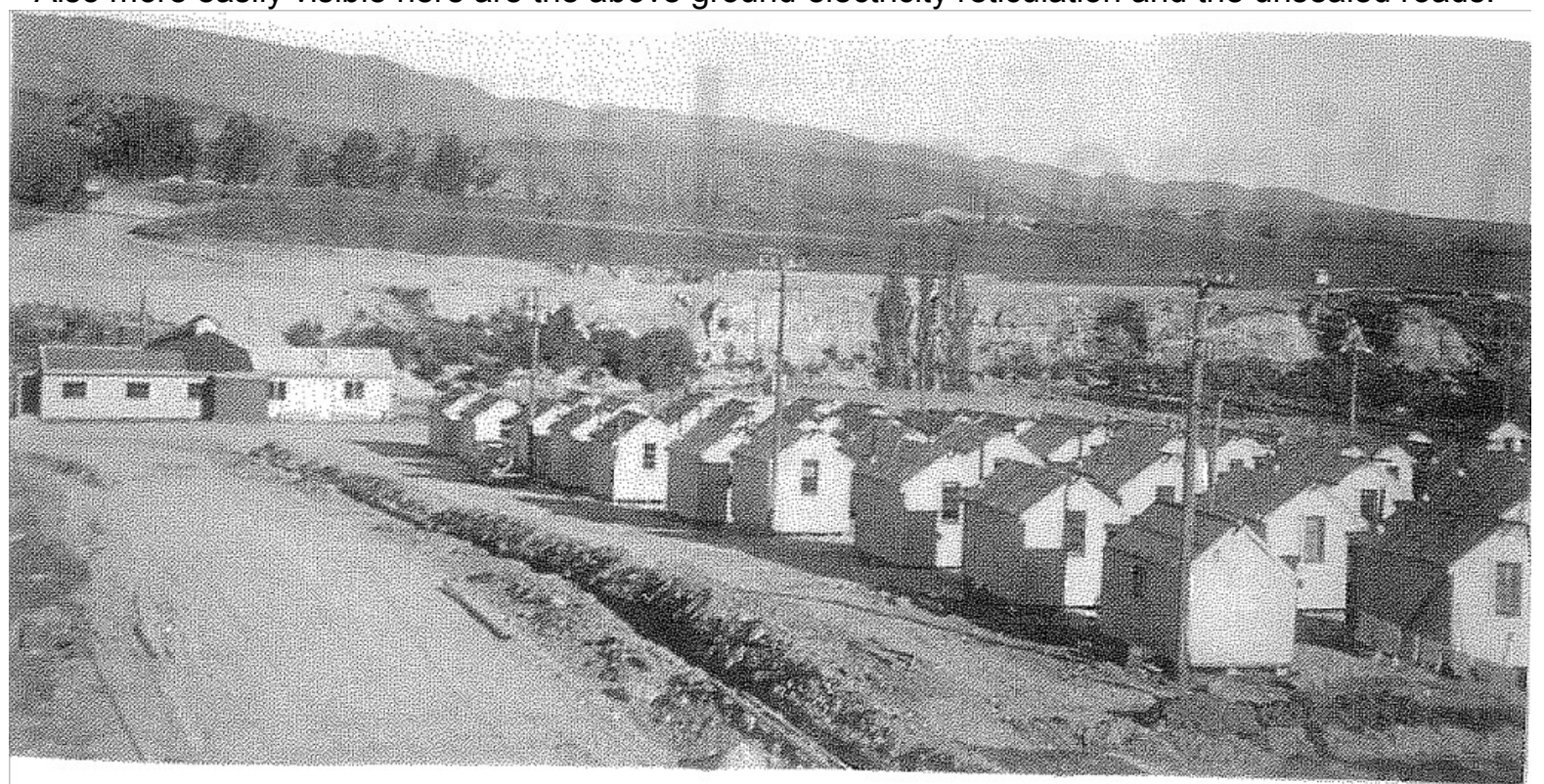

C4: (Photo courtesy of Otago Daily Times archives)

This picture shows that there is some variation in the location of the huts, which are more staggered in this area of the camp than is clearly visible in other pictures.

The earthworks required for the siting of the accommodations and the unsealed roads are also visible here. 


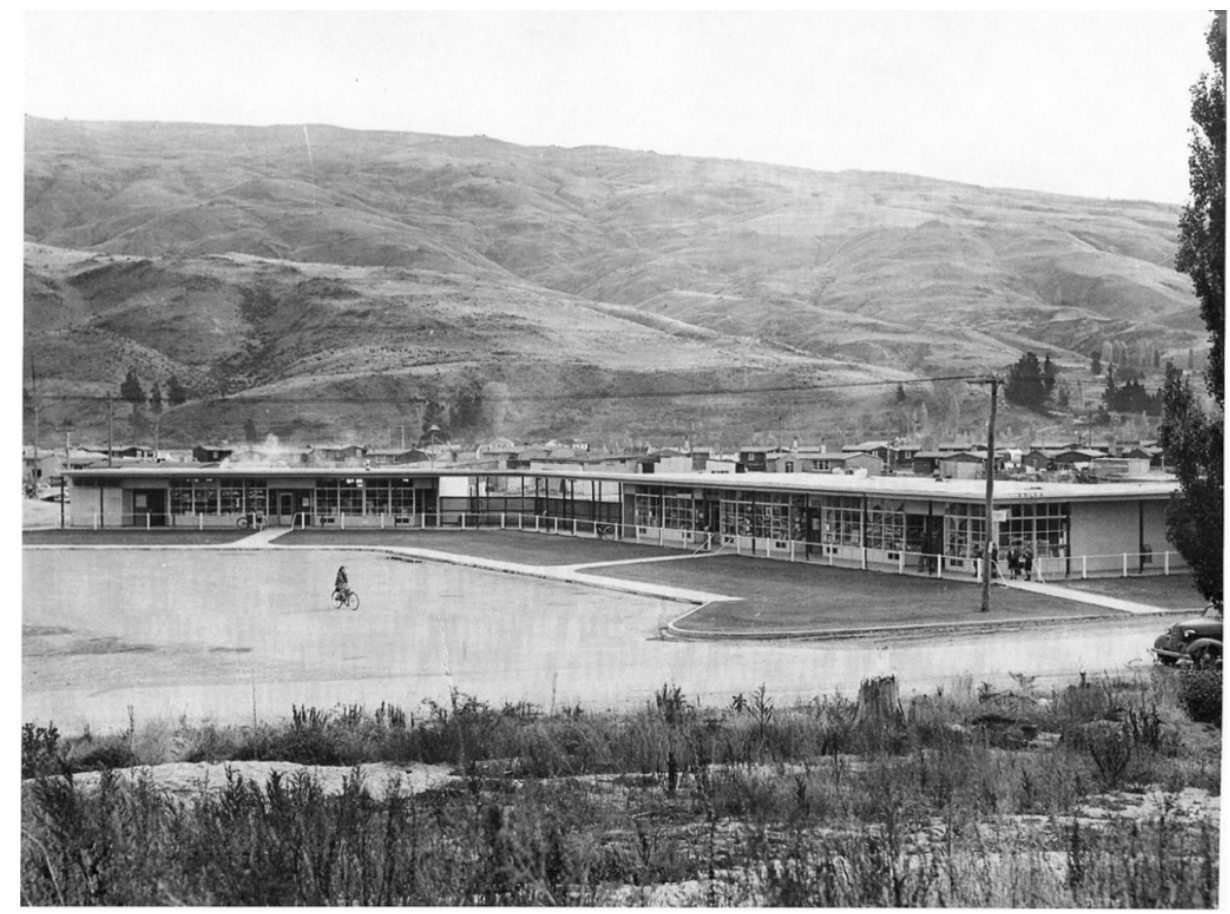

C5: Shopping centre at the Hydro Electric Station, Roxburgh, June 1952

(NZ Free Lance Collection, Alexander Turnbull Library, Wellington, NZ. Ref \#: F-45713-1/2)

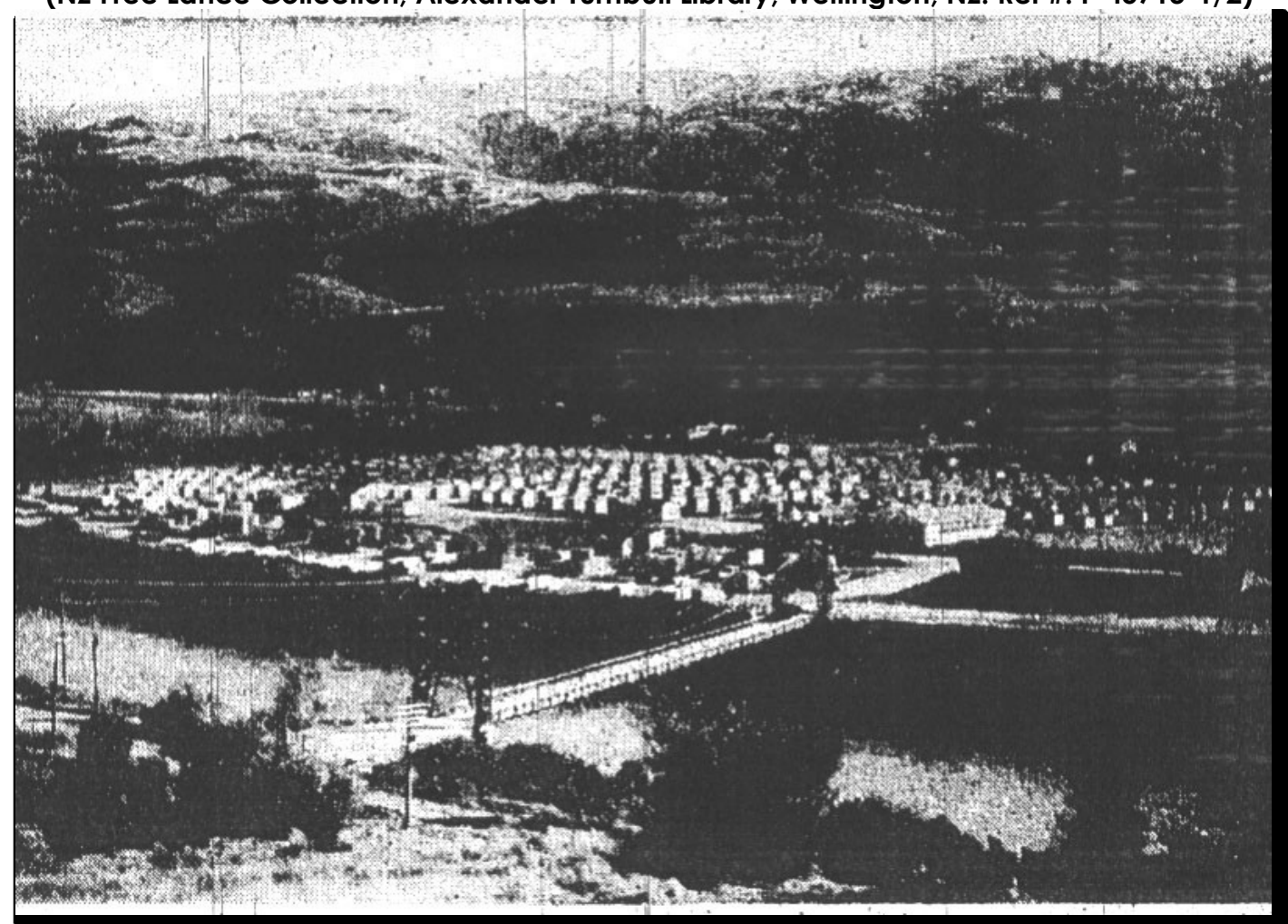

C6: Singlemens camps 1 and 2 from the east, 1953

(Otago Daily Times, first published page 11, ODT, July 1, 1953) 


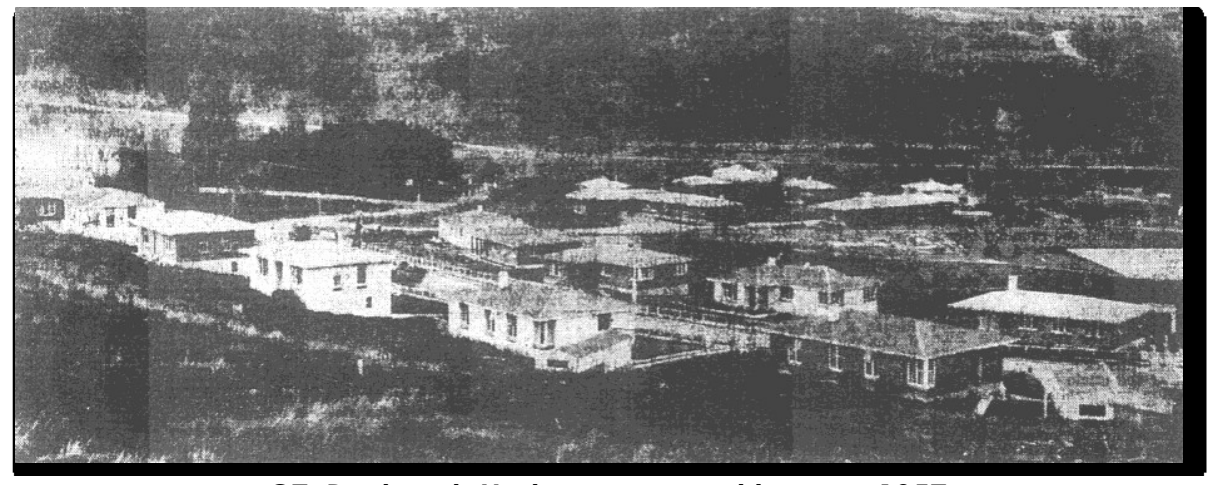

C7: Roxburgh Hydro permanent houses, 1957

(Otago Daily Times, first published p5, ODT, May 11, 1957)

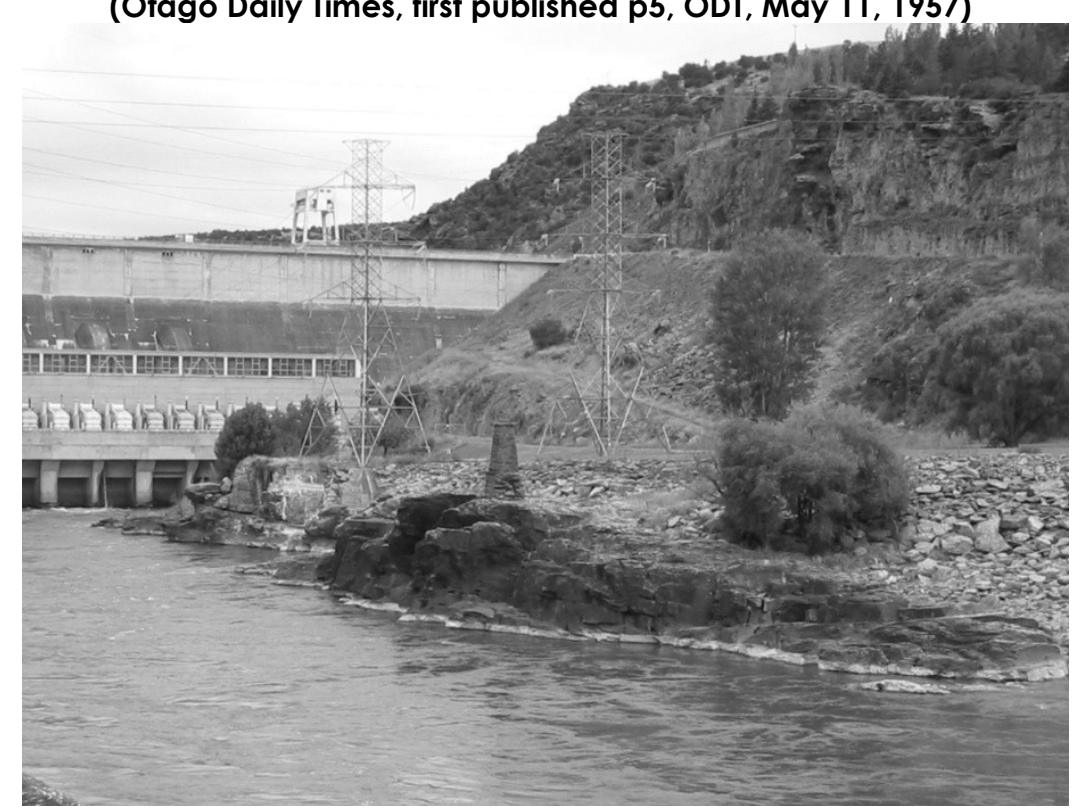

C8: Roxburgh hydro village site 2005

(Photo by the author)

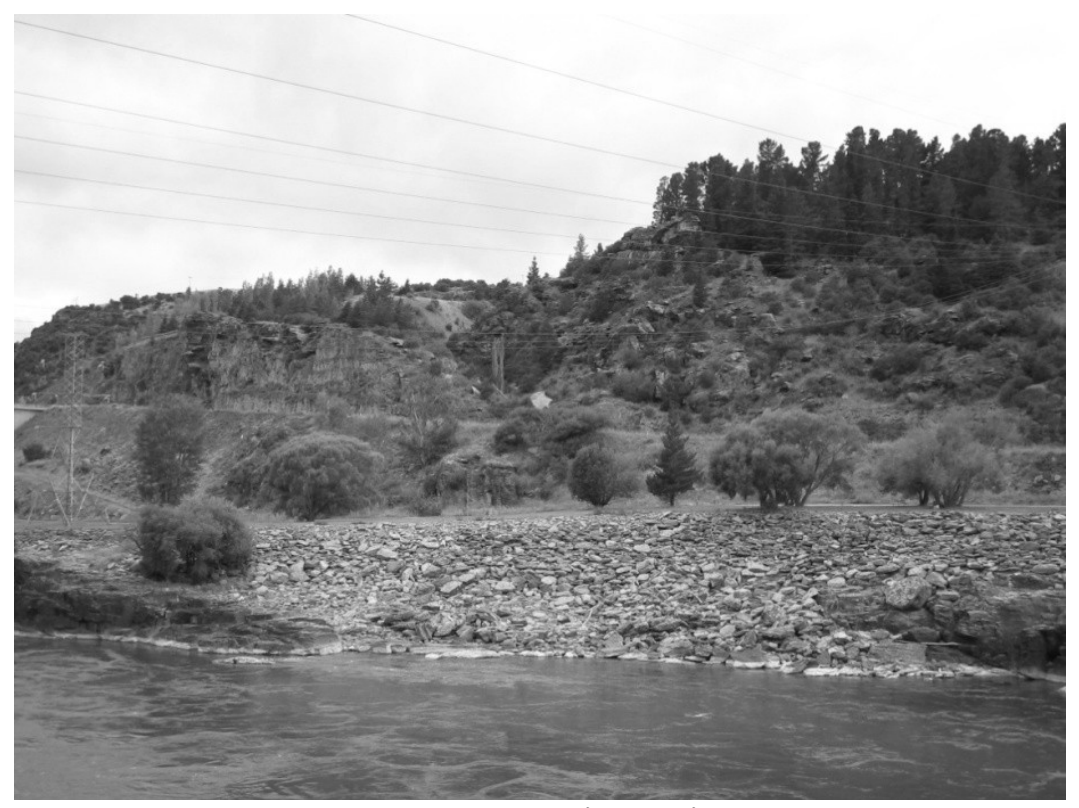

C9: Roxburgh hydro village site, 2005

(Photo by the author) 


\section{D: Otematata}

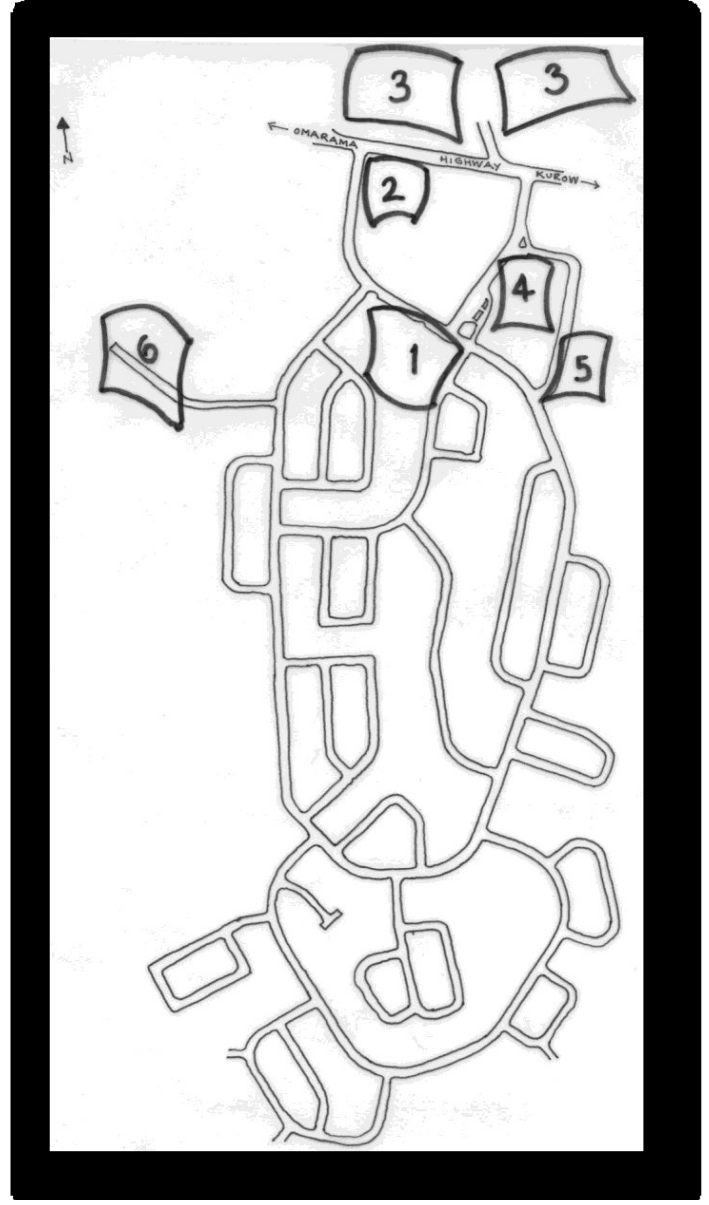

D1: Otematata Town Plan, 1960s

1. Shopping centre

2. MOWD Offices

3. Singlemens' huts 4. Hostels

5. Top tier management*

6. Second tier management*

*Note: some management occupied other areas throughout township, housing location did not usually have the same social stratification as it had had at previous camps 


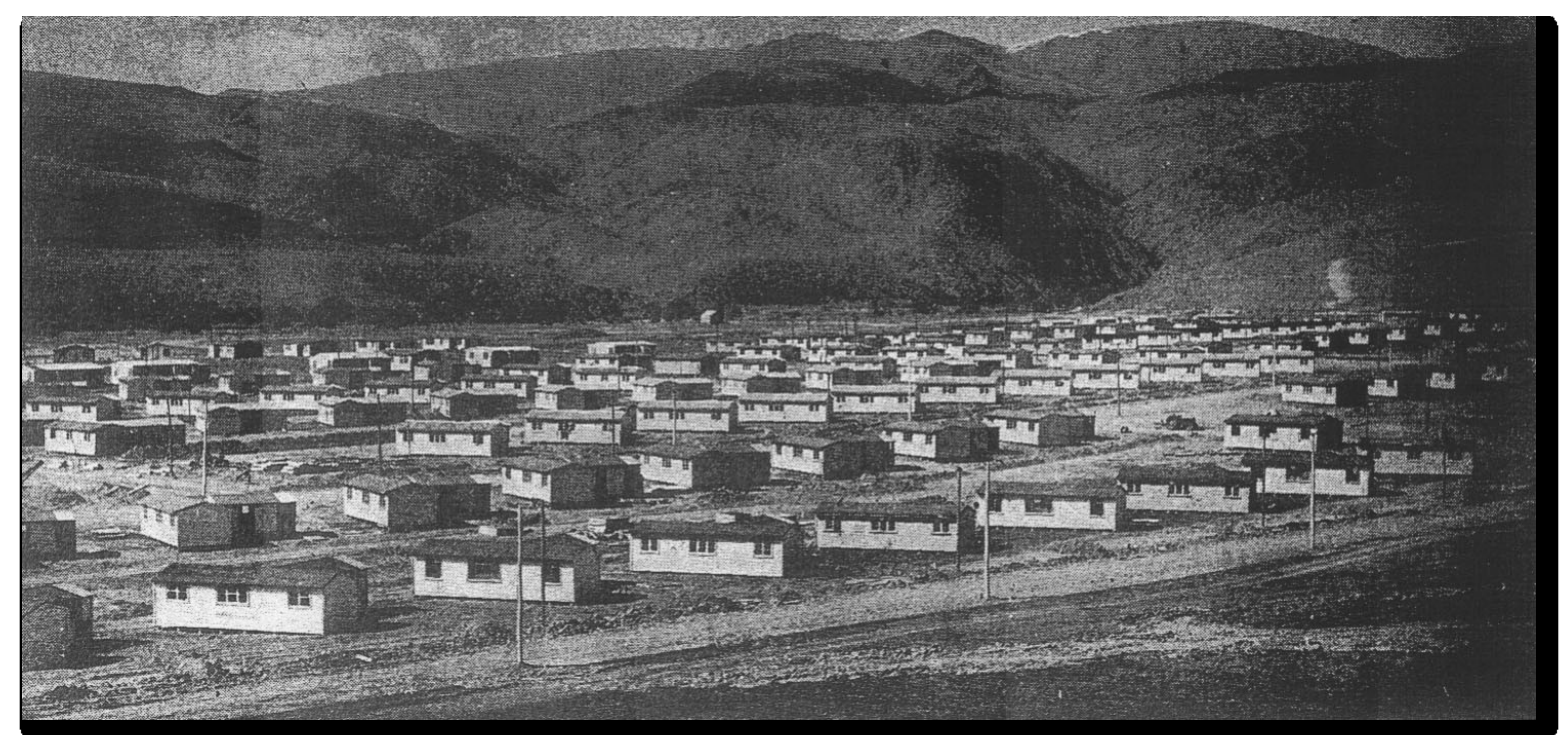

D2: Otematata, 1958

(Otago Daily Times, first published page 1, ODT, September 30, 1958)

This photo shows the differences between the accommodations here and the family accommodations at the earlier camps - corrugated iron roofs have replaced malthoid, the accommodations are houses rather than an amalgamation of huts, there are no chimneys (increasing transportability) and there is now more separation between the houses.

Some of these houses were transported from Roxburgh and completely renovated. It is very hard to see any similarities between the two.

There is still no guttering on these houses.

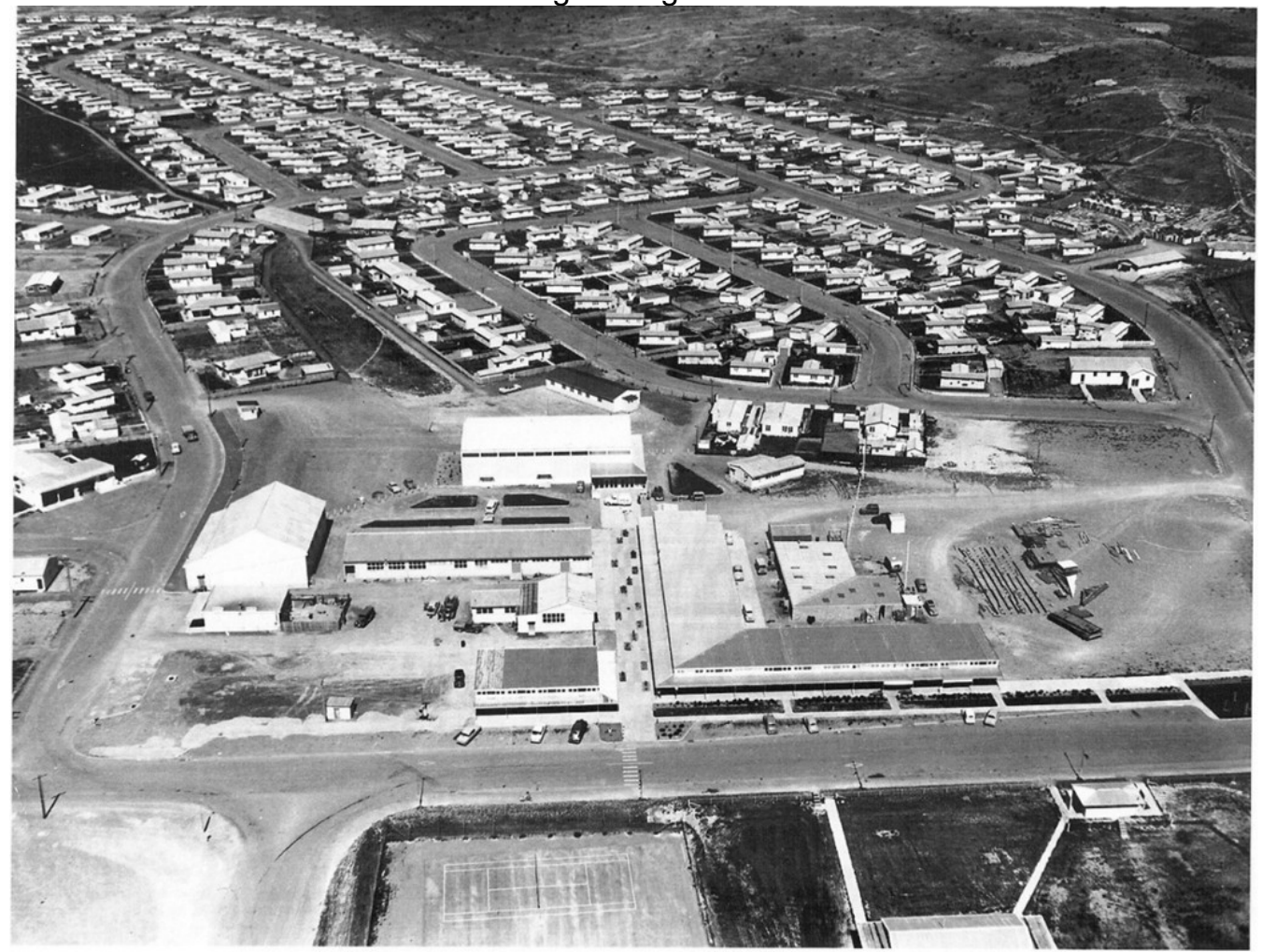

D3: Ministry of Works township of Otematata, 1960

(Alexander Turnbull Library, Wellington, NZ. Ref \#: PICT-000085)

The layout of houses, angled on the streets, was most probably a result of the ease of transportability

- trucks could deliver to sites more easily on an angle than straight on.

In contrast to the earlier sites, the roads in Otematata are sealed. 


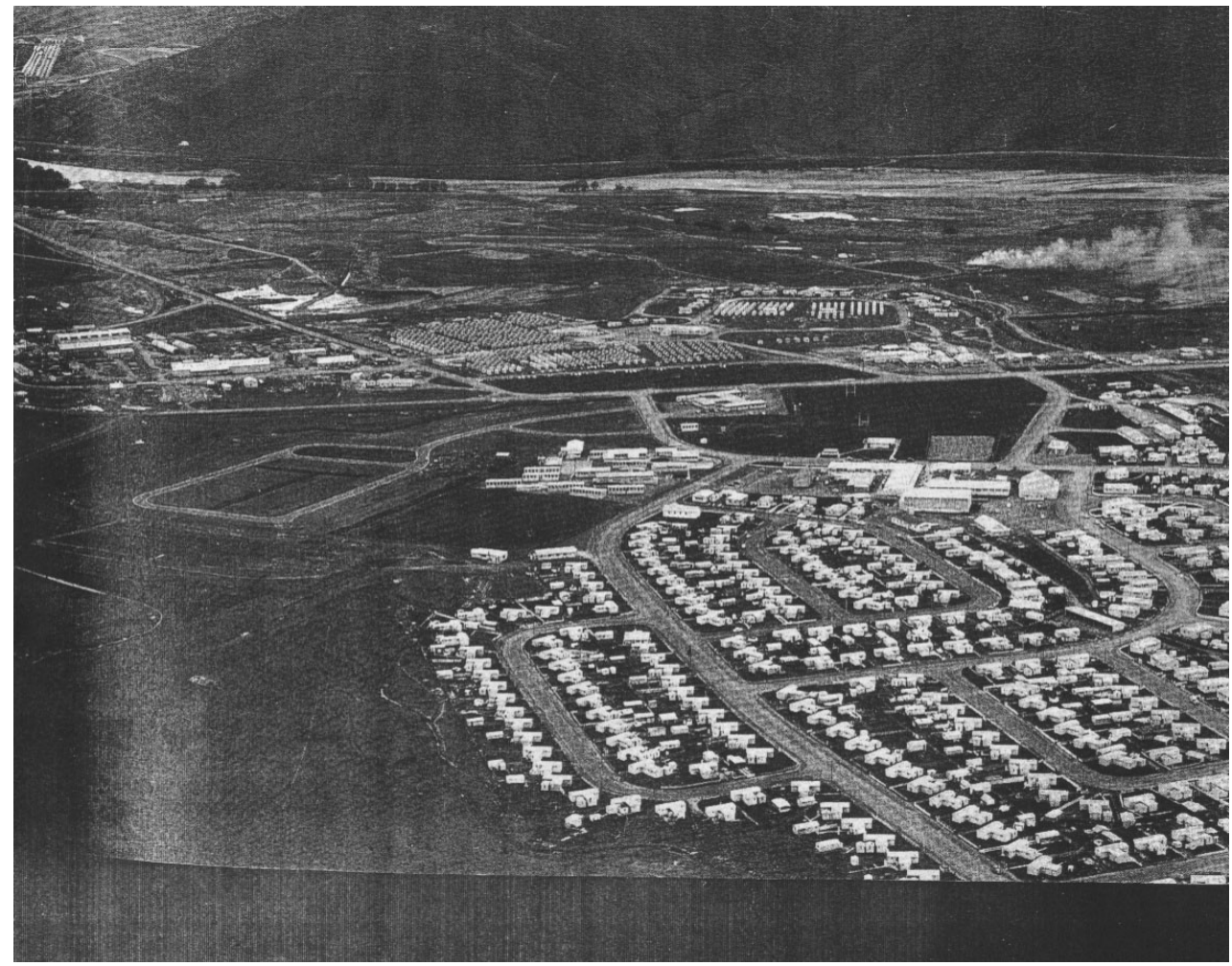

D4: Otematata, 1965

(Otago Daily Times)

Note that the permanent houses have not been built yet - Rata Drive is formed at the left of the photo, but has no houses on it. Also note the singlemens huts at the top of the photo (on the other side of the main road between Omarama and Kurow) - these have been completely removed. However, this photo clearly shows the separation between married housing and singlemens' accommodations. At the top left of the photo the Benmore Dam tailrace can be seen at the work site.

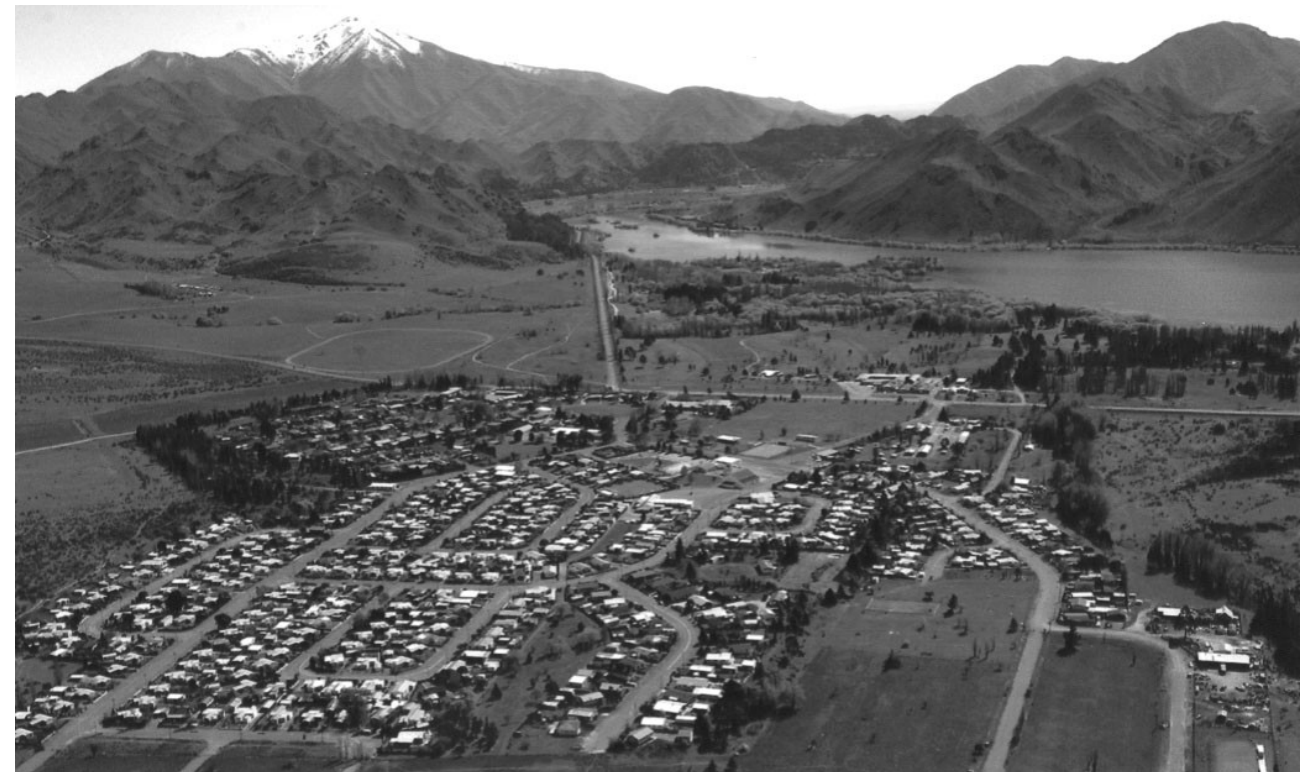

D5: Otematata, 2004

(Otago Daily Times)

It is easy to see the planting of non-natives in this photo, especially around the permanent houses on Rata Drive at the top left of the town in this photo.

Although the roads actually stop at the line of the houses today, the damage to the land where the roads were located can be clearly seen at the bottom of the photo. 


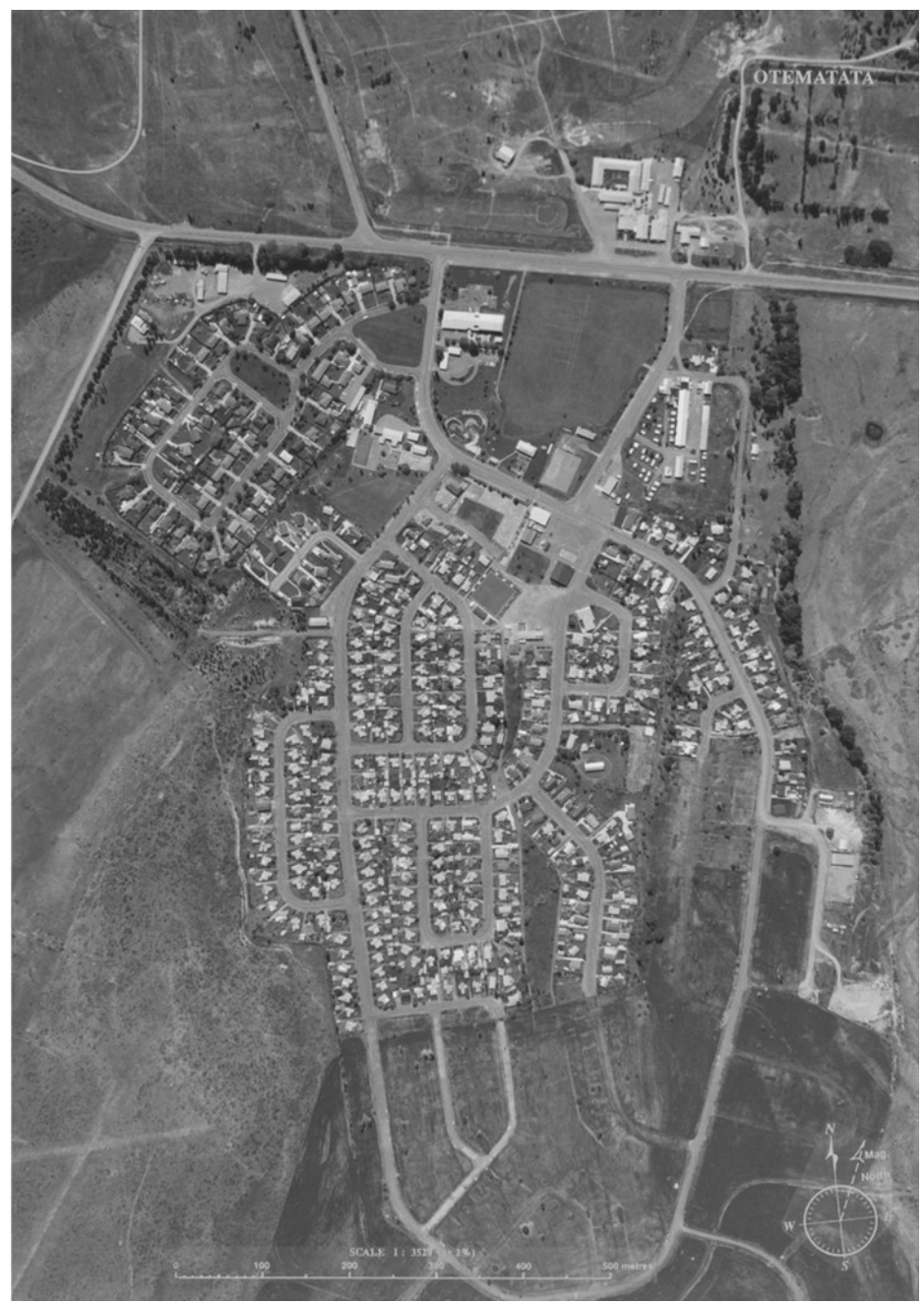

D6: Aerial photo of Otematata, 2004

(Waitaki District Council)

Note the damage to the land at the top of the photo, this is where huts and hostels were located. Note also the damage to the site in the bottom quarter of the photo where roads are still highly visible despite having been torn up c. 1970

This photo also clearly shows the differences between the permanent housing (Rata Ave at top left) and the temporary housing which has remained - plantings, site sizes, orientation of houses on sites

(built on site $v$ delivered), etc 


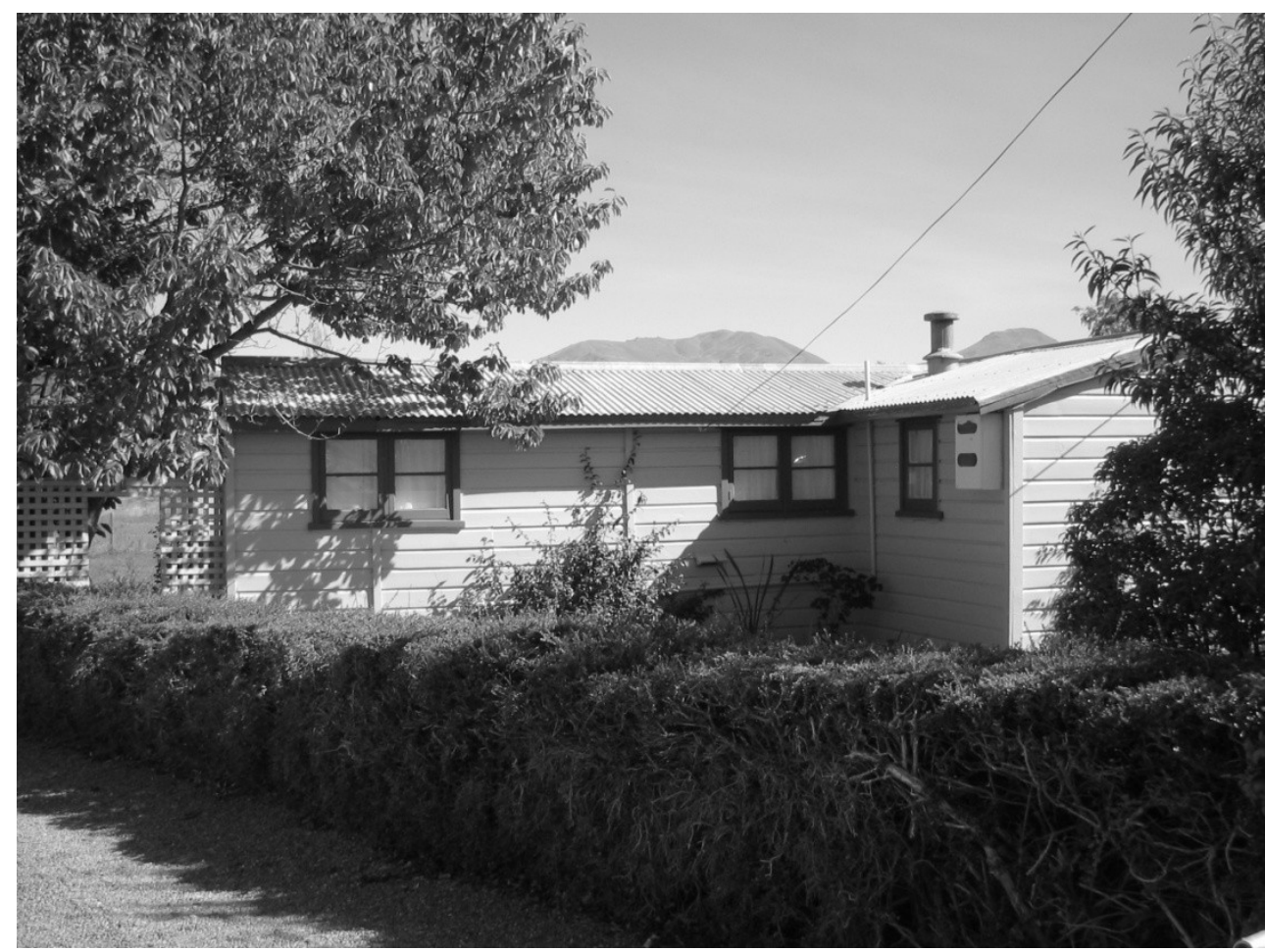

D7: Otematata, 2005

(Photo by the author)

House with new cladding (likely to have been done while adding insulation to the house) and solid fuel heating added.

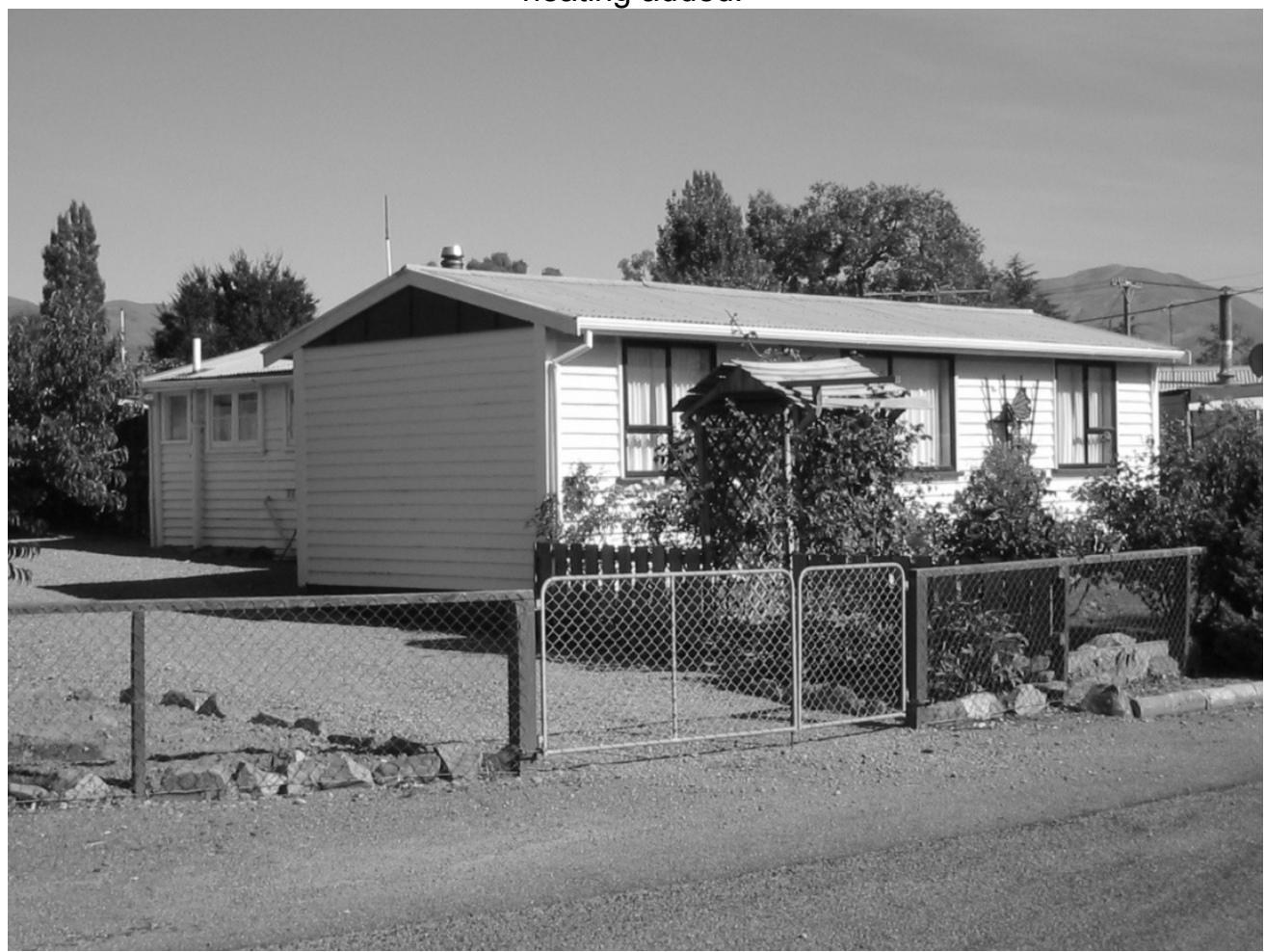

D8: Otematata, 2005

(Photo by the author)

This house has had the windows replaced with aluminium joinery at the front of the building, guttering has been added to the roof, there appears to be a new roof on the building and new cladding (probably done whilst adding insulation to the building) and solid fuel heating has been added. 


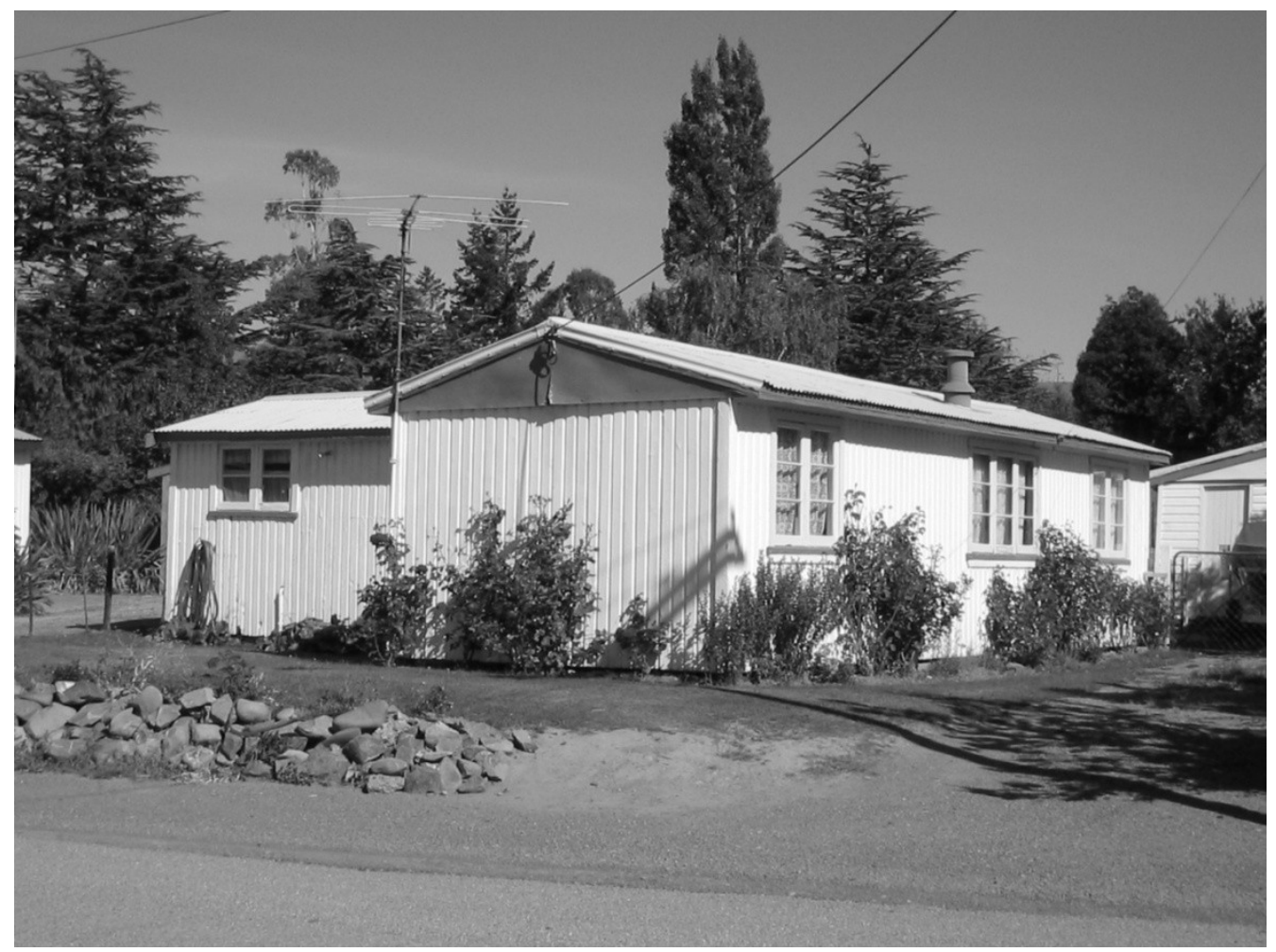

D9: Otematata, 2005

(Photo by the author)

Heating has been replaced with a solid fuel burner and false barge board added to the house. False barge boards have been a popular addition to the houses in Otematata.

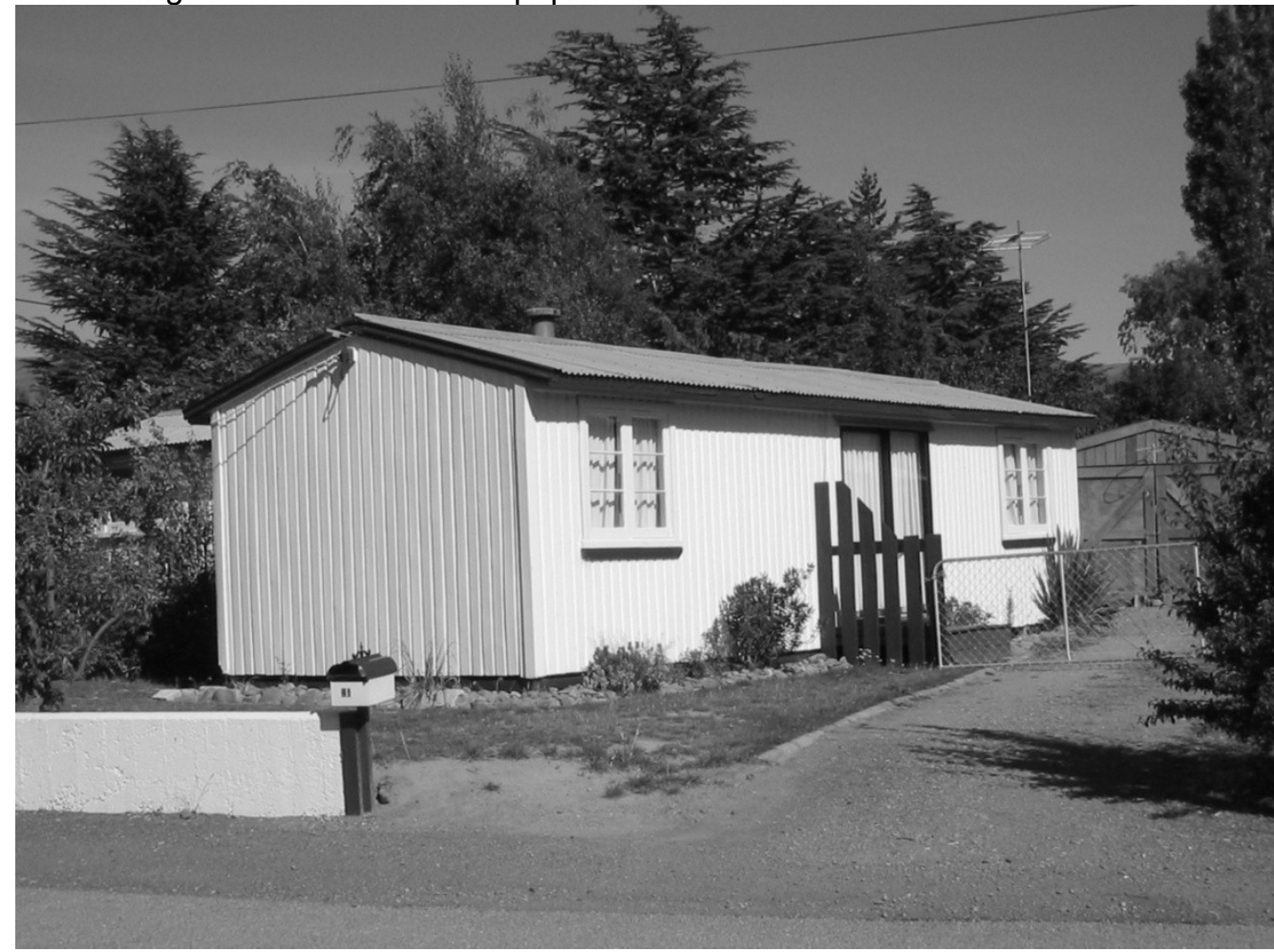

D10: Otematata, 2005

(Photo by the author)

A new entrance has been created at the centre of the longer side of this house. This house also has dark boards added at the bottom of the walls which hide the gap between the house and the ground and the concrete footings. 


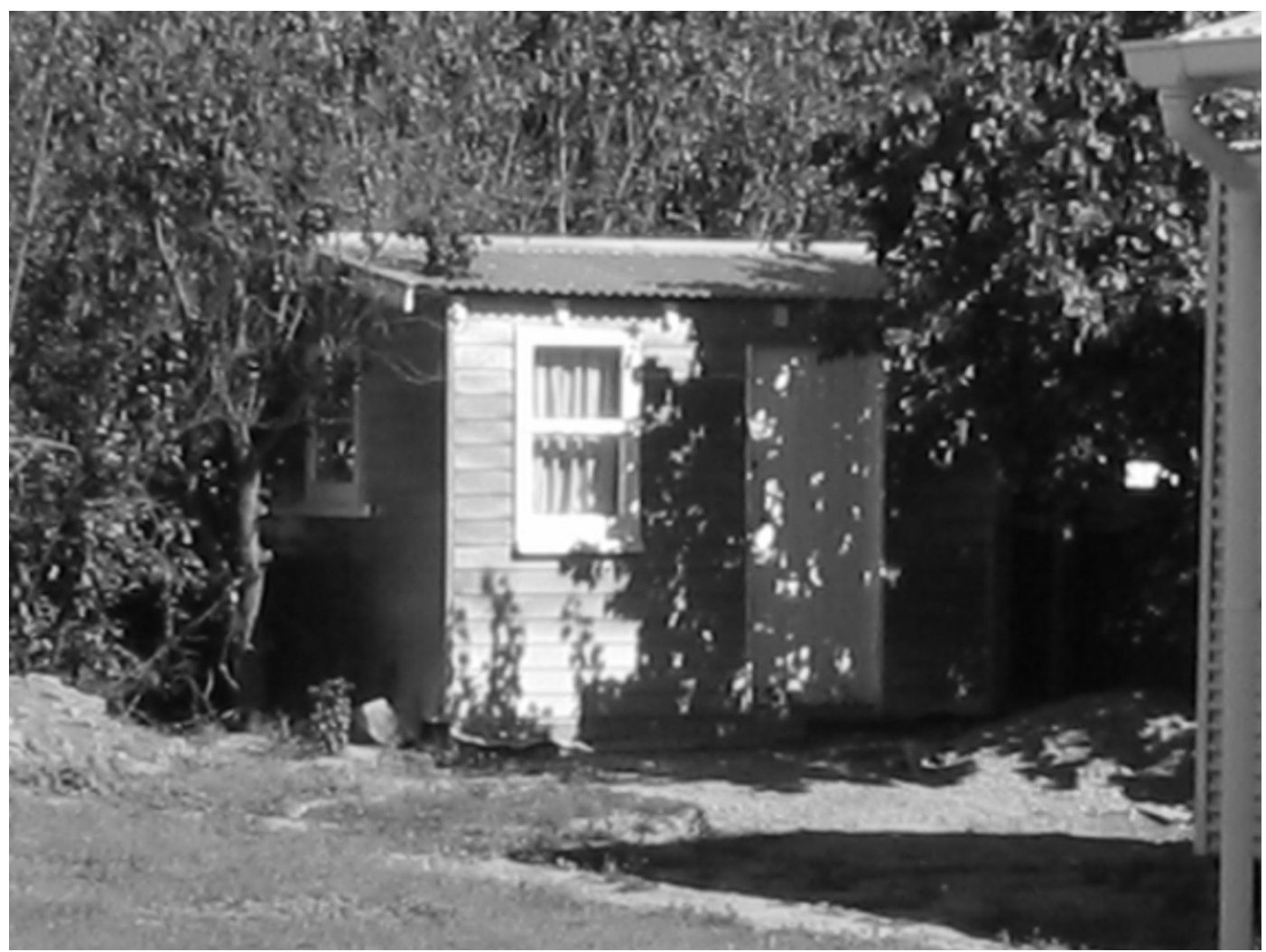

D11: Otematata, 2005

(Photo by the author)

Singlemens hut in backyard as additional storage/bedroom.

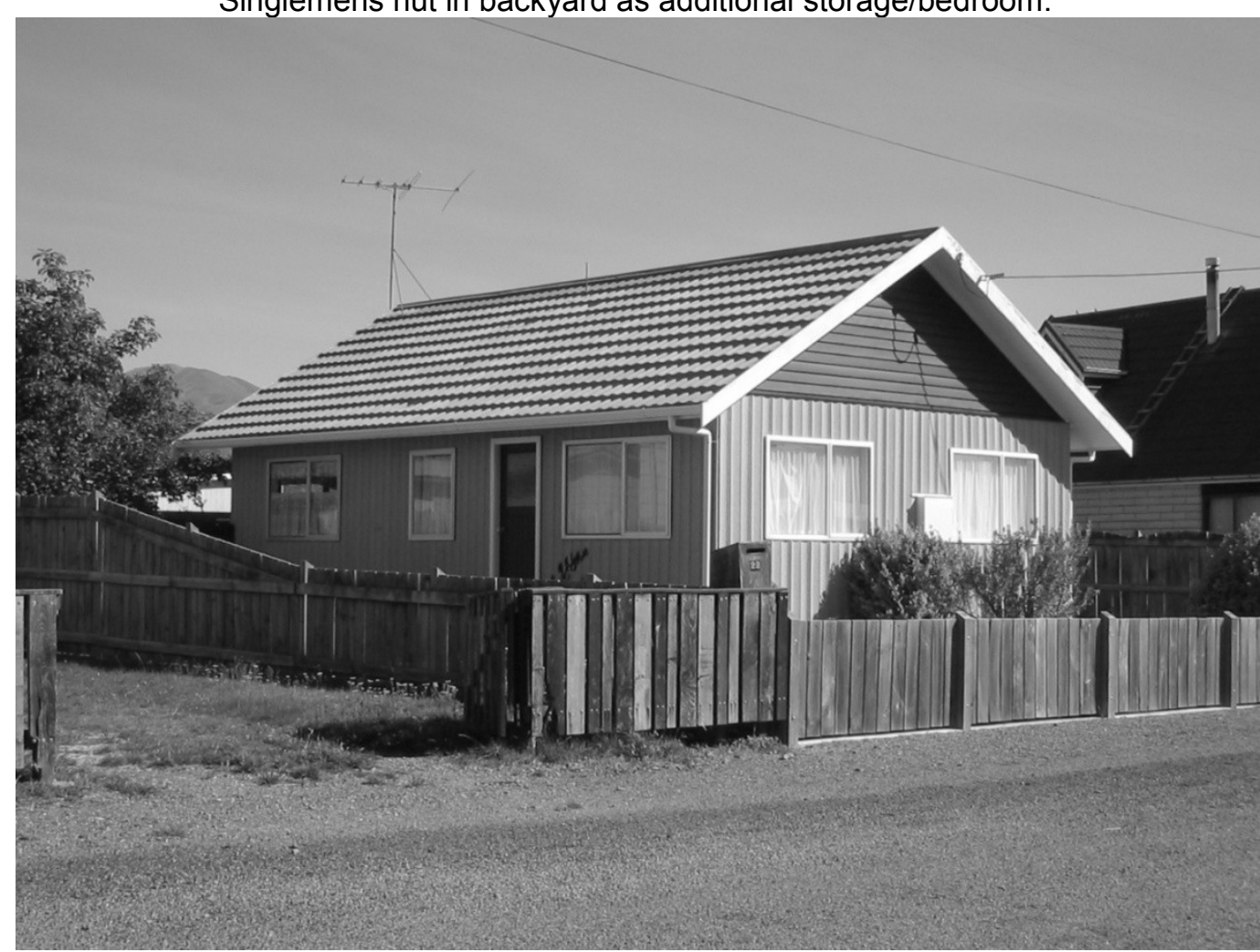

D12: Otematata, 2005

(Photo by the author)

Windows have been replaced with aluminium joinery, new roof, guttering and external cladding 


\section{Otematata Visual Survey Data}

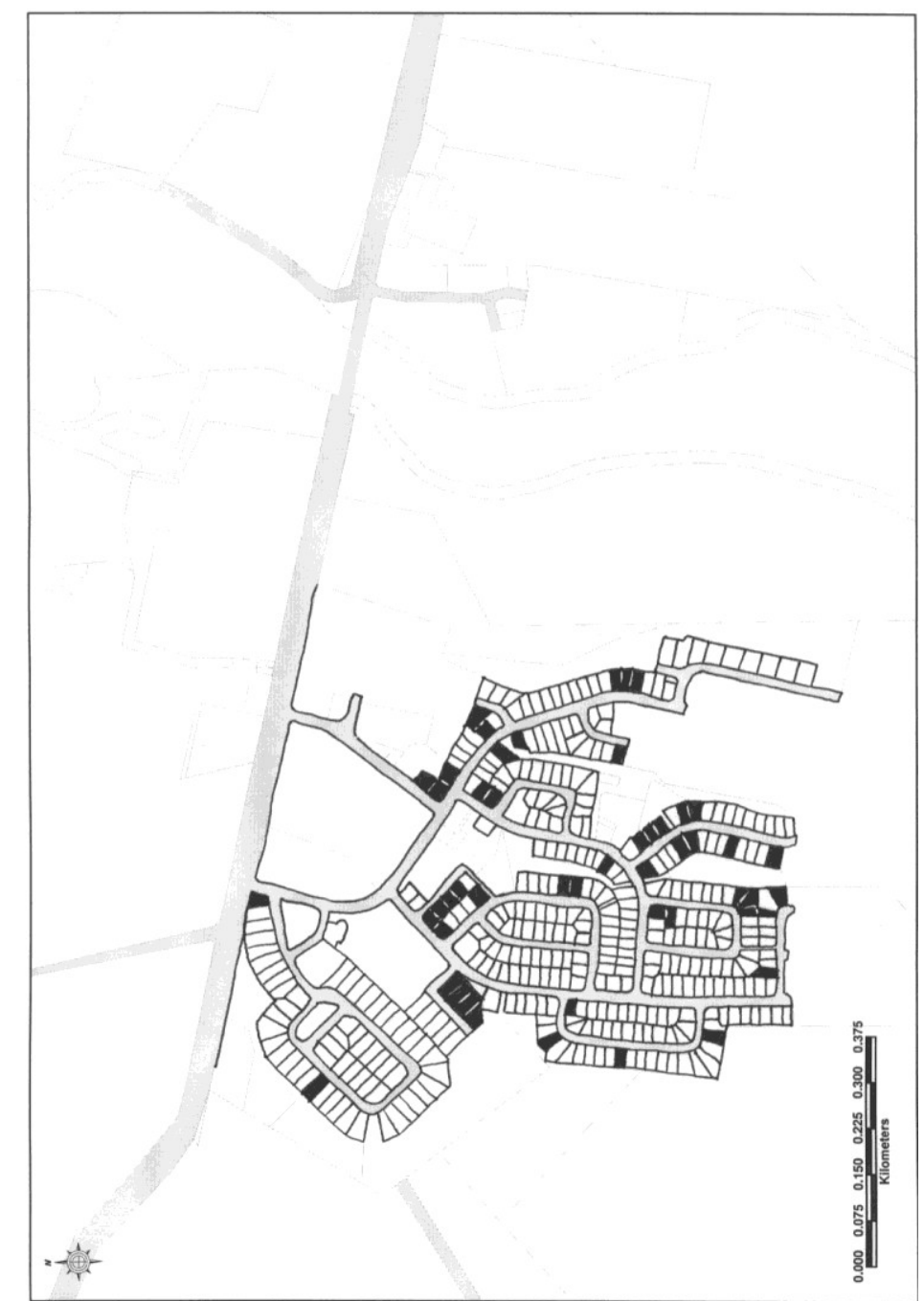

D13: Town plan of Otematata, 2005

Sections shown are those that retained a house when Otematata was handed over to Waitaki District.

Sections shown in black are those that no longer have the original house on them 
E: 1MTT

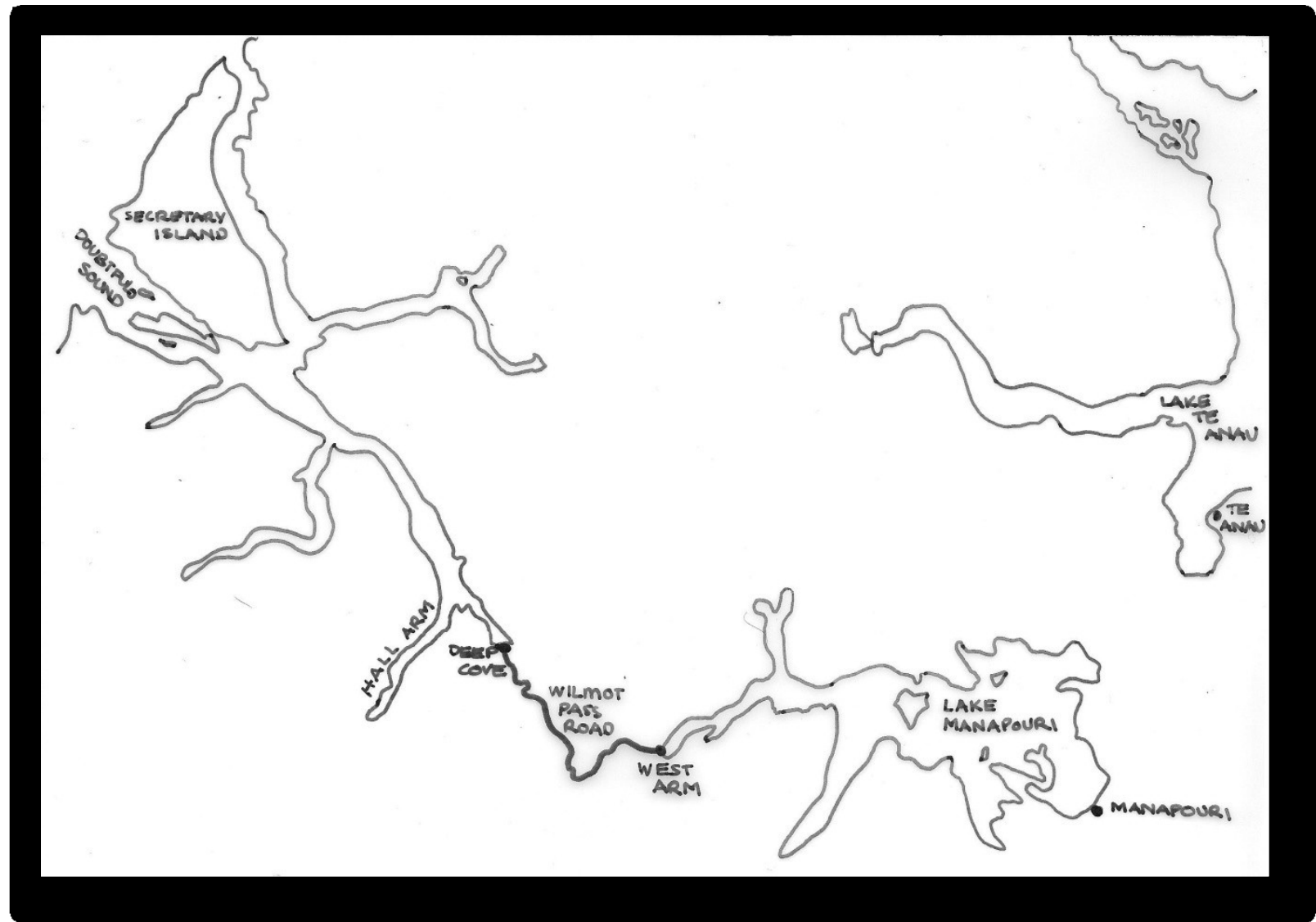

E1: Map of Tailrace Tunnel accommodation locations 


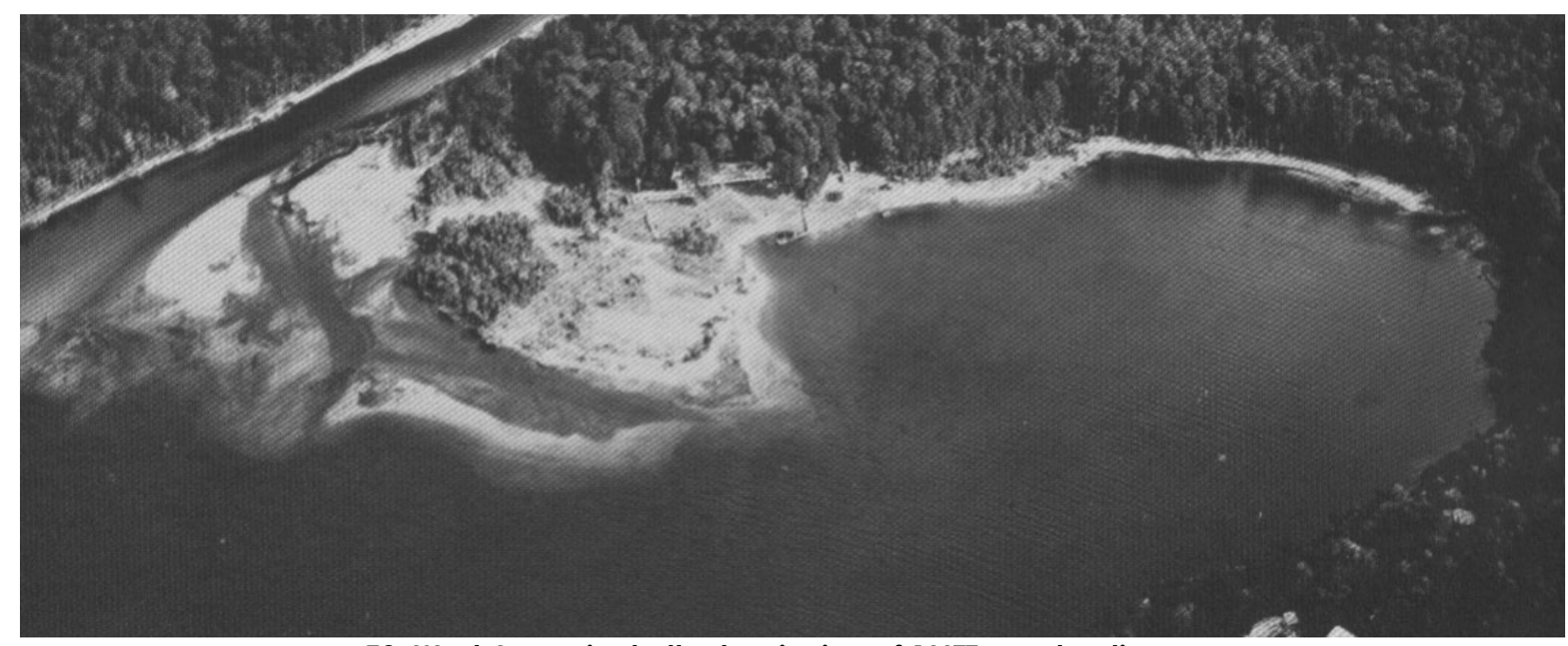

E2: West Arm prior to the beginning of $1 \mathrm{MTT}$ construction

(Photo by Ministry of Works and Development, courtesy of Meridian Energy)

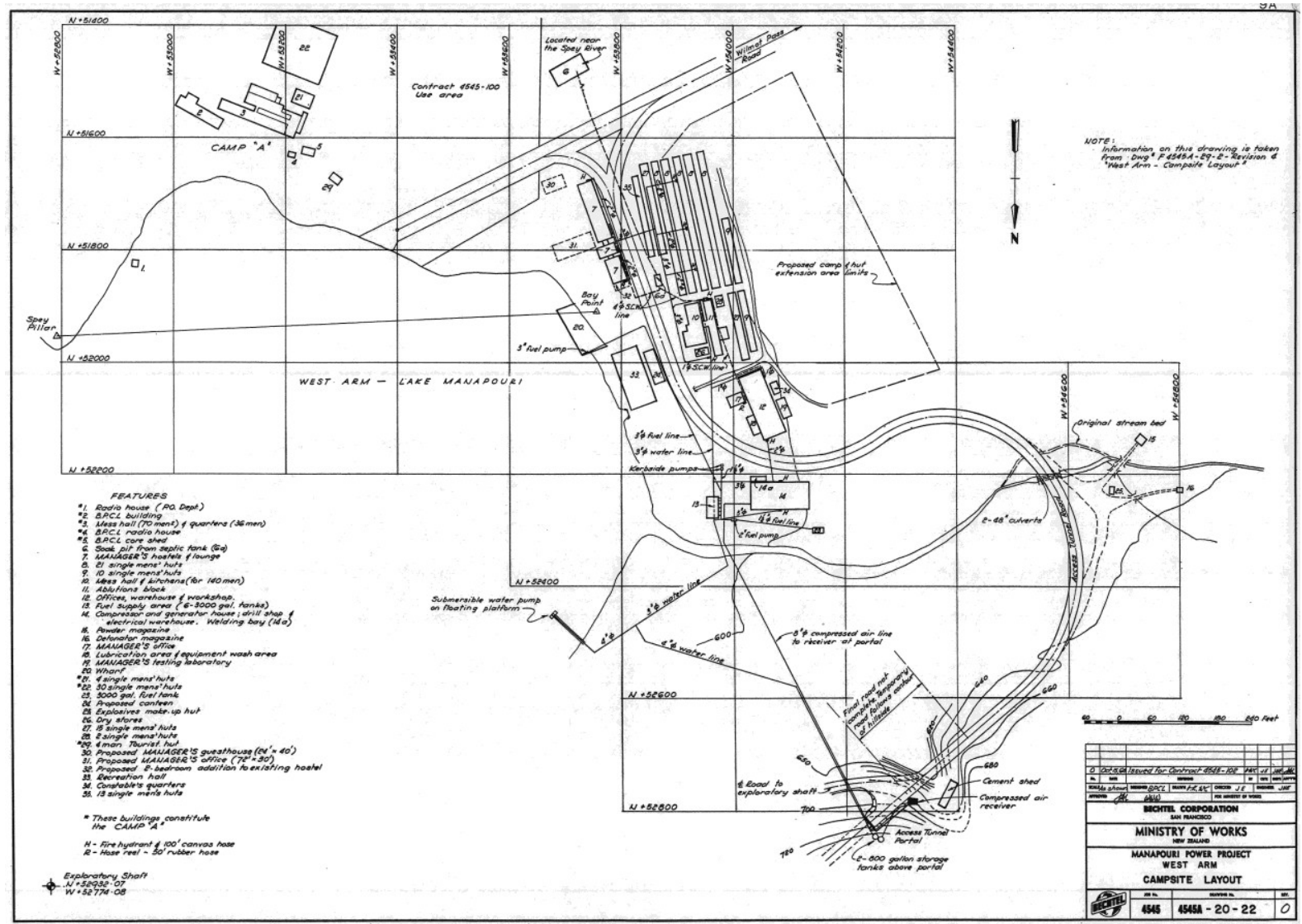

E3: 1MTT camp at West Arm

(plan courtesy of Meridian Energy) 


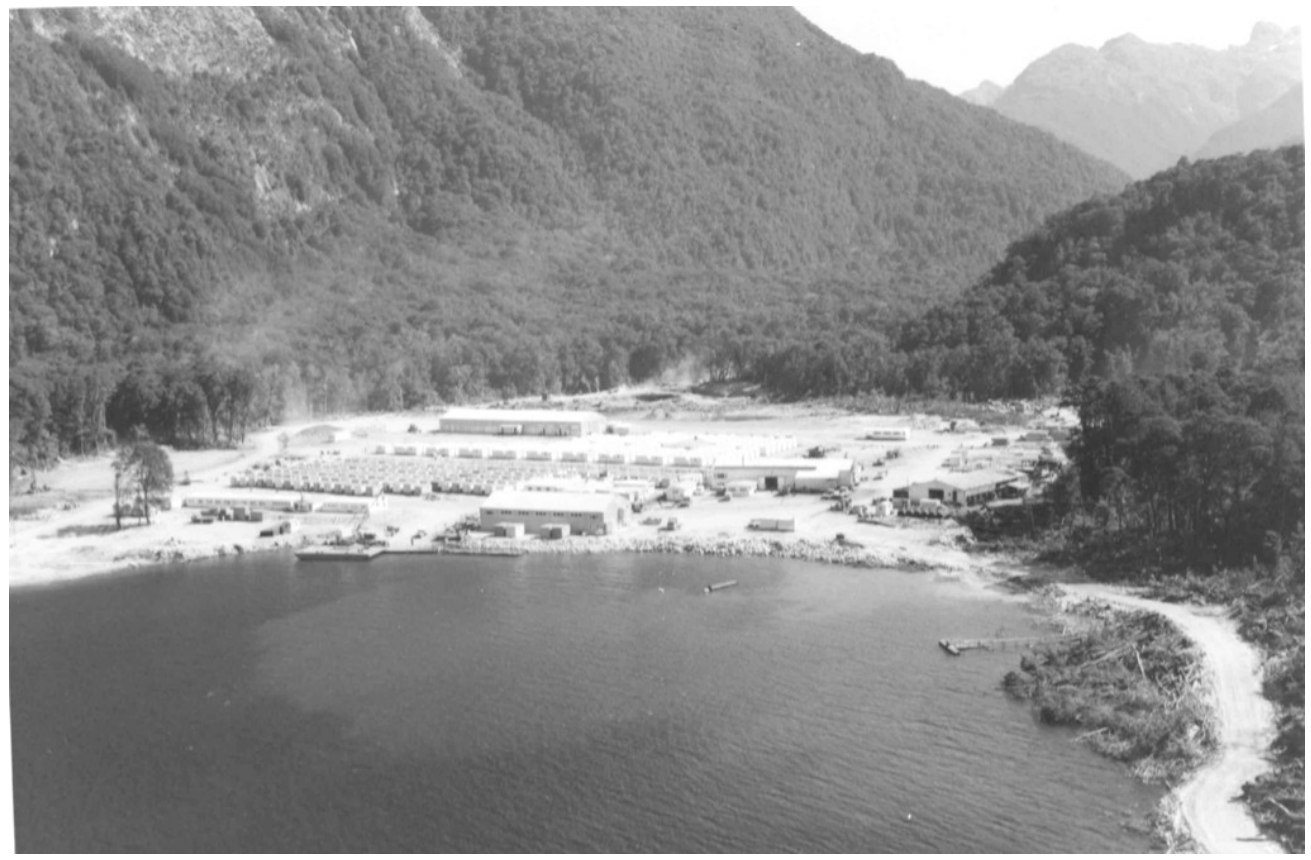

E4: 1MTT camp at West Arm

(Photo by Ministry of Works and Development, courtesy of Meridian Energy)

Note the large amount of earthworks which have been undertaken on teh accommodation site.

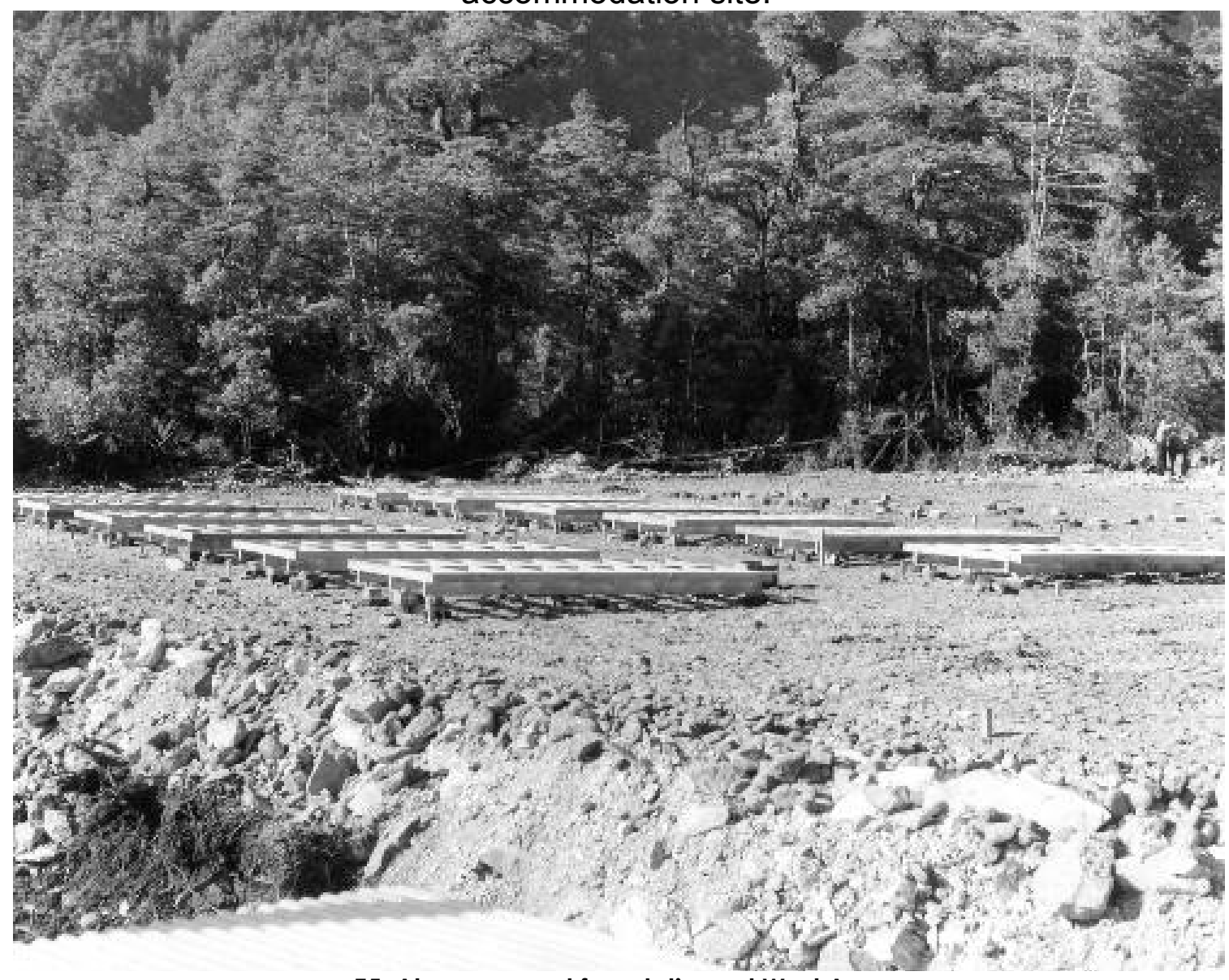

E5: Above ground foundations at West Arm

(Photo by Ministry of Works and Development, courtesy of Meridian Energy) 


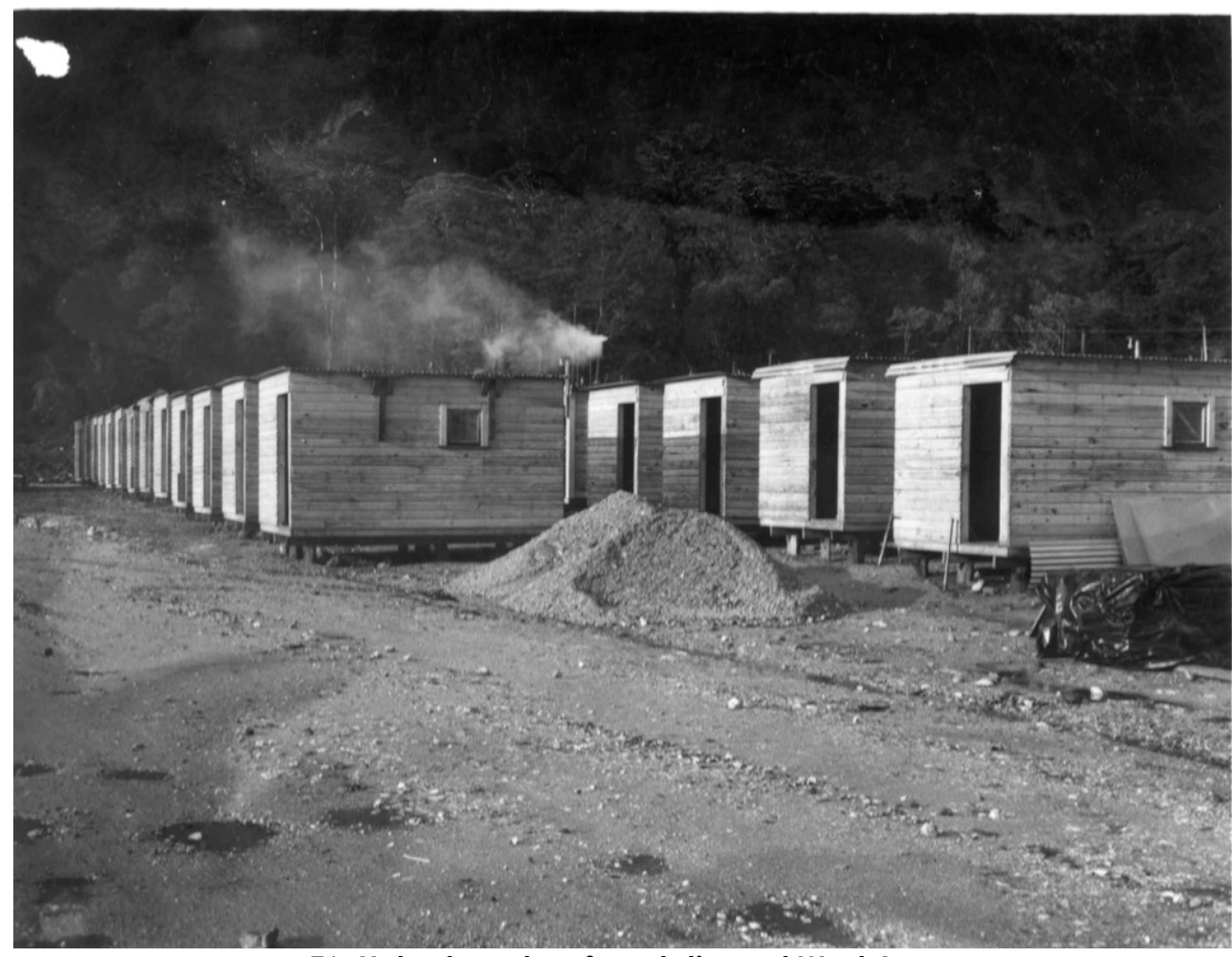

E6: Huts placed on foundations at West Arm

(Photo by Ministry of Works and Development, courtesy of Meridian Energy)

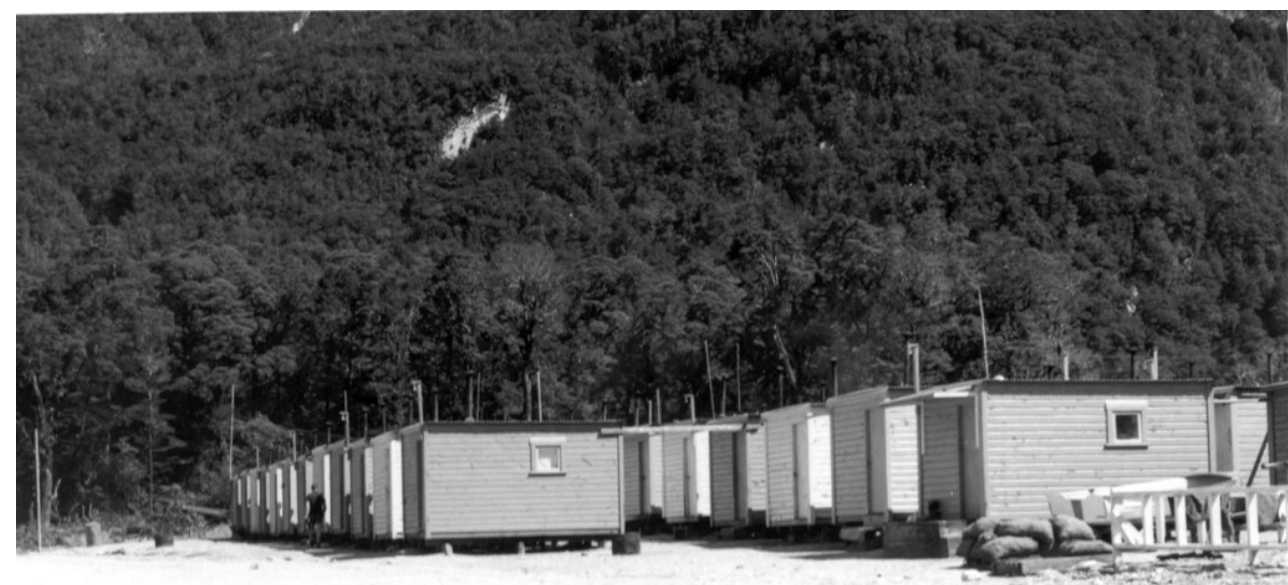

E7: 1MTT huts at West Arm

(Photo by Ministry of Works and Development, courtesy of Meridian Energy)

This photo shows the close proximity of the huts, the very small windows and the uniform layout. Infrared heating was provided in these huts in order to make the huts easily transportable and also to protect the National Park which surrounds the camp. 


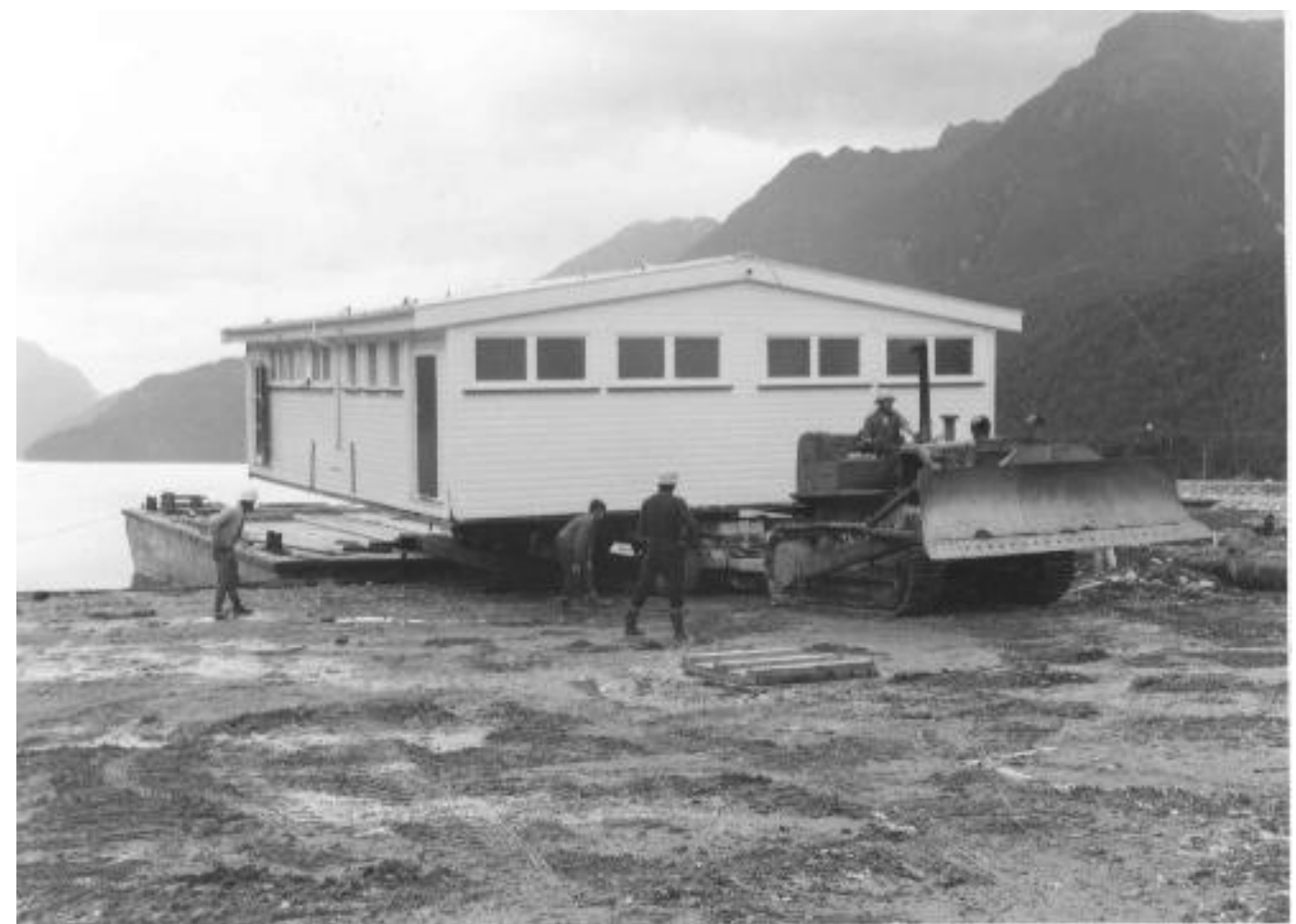

E8: Ablutions block being barged into West Arm.

(Photo by Ministry of Works and Development, courtesy of Meridian Energy)

This picture shows how damp the site was, despite the massive earthworks already done to overcome this, caused by both a very swampy site and a very high rainfall 


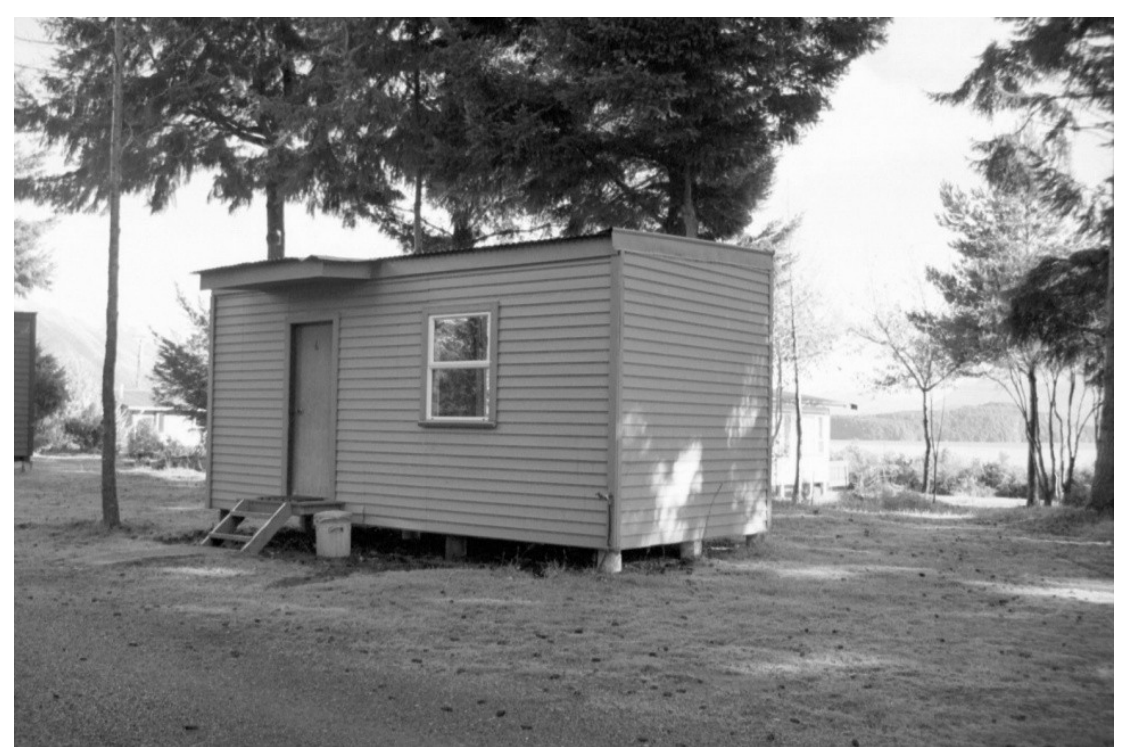

E9: 1MTT hut relocated to Manapouri Holiday Park

(Photo by the author)

This hut has been barged across Lake Manapouri and relocated to the Manapouri Holiday Park. It has had a roof added over the entrance, the entry door has been moved to the long axis of the building and the window has been enlarged.

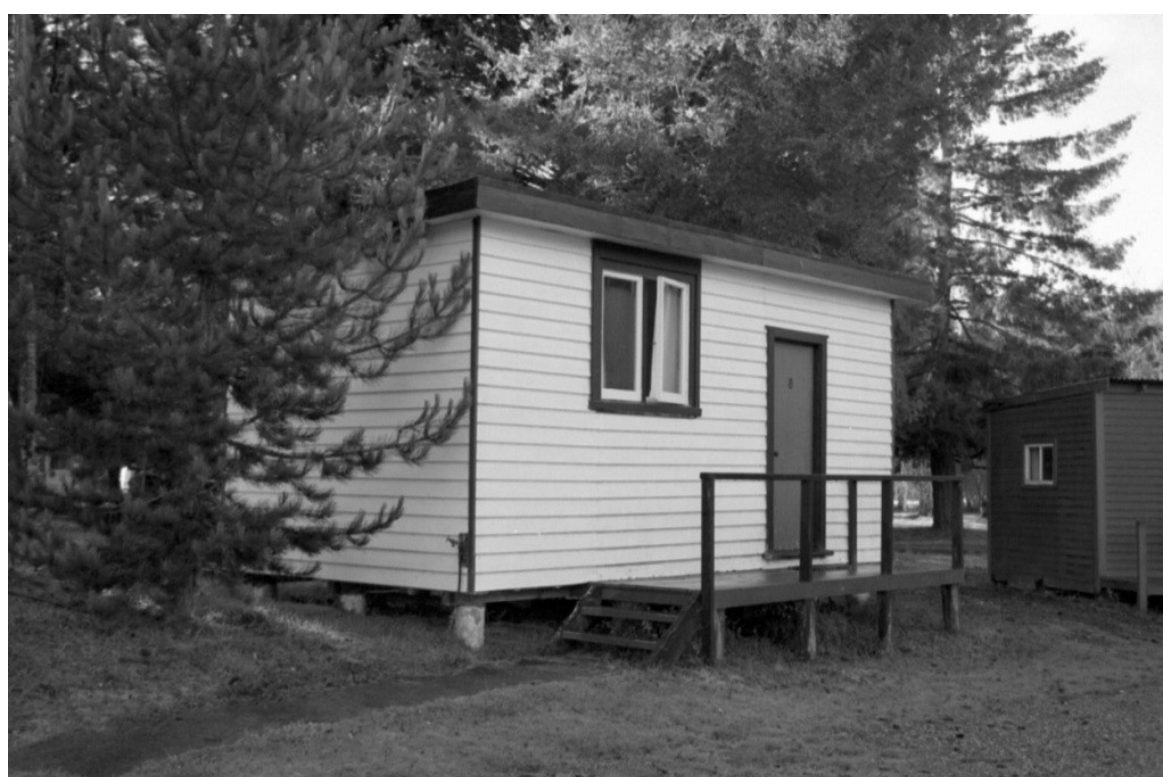

E10: 1MTT hut relocated to Manapouri Holiday Park (Photo by the author)

This photo shows the concrete piles which the relocated huts have been placed on in this location. A small verandah has been added, the door has been moved to the long axis and the window has been enlarged. 


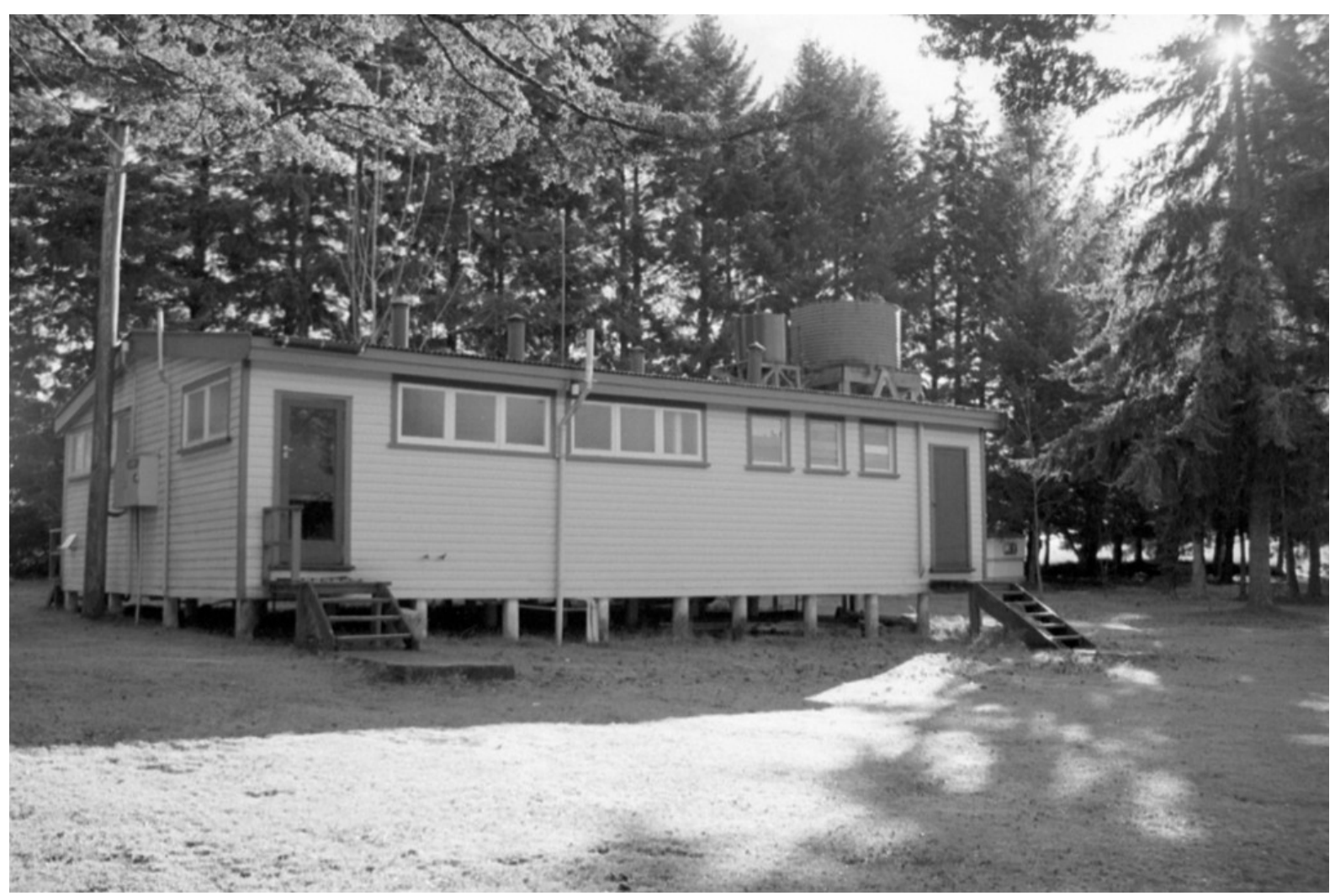

E1 1: 1MTT ablutions block relocated to Manapouri Holiday Park

(Photo by the author)

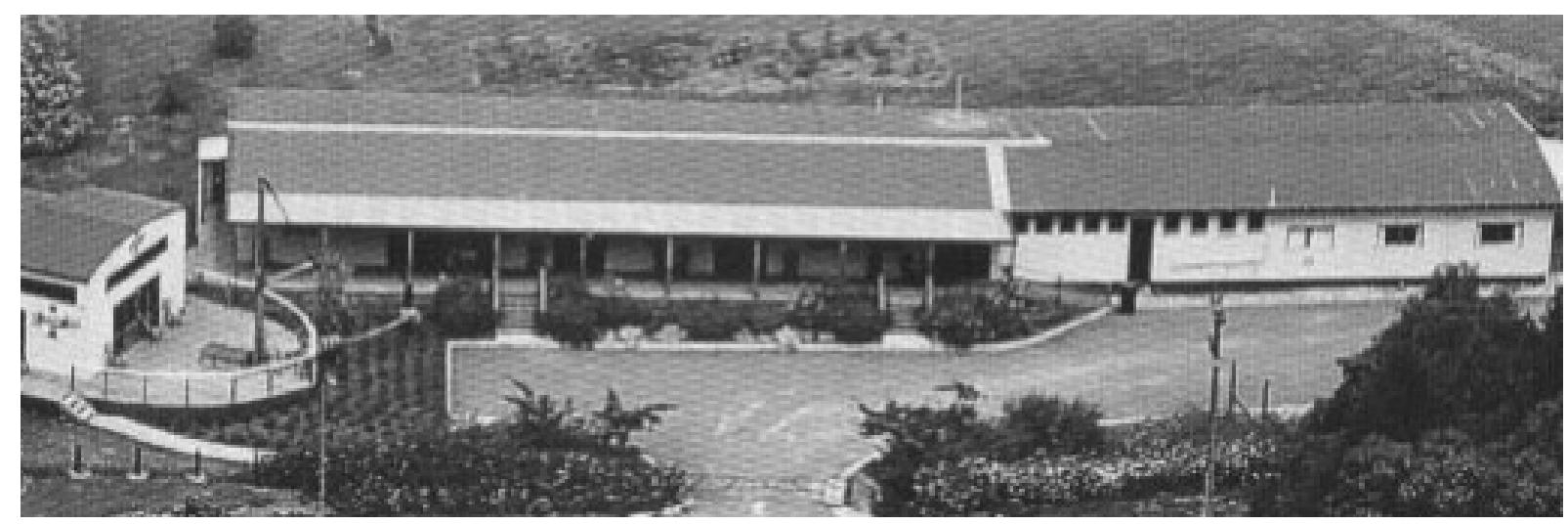

E12: Parts of $1 M T$ Test Arm hostel relocated to Te Anau Holiday Park. (Photo courtesy of Te Anau Holiday Park) 


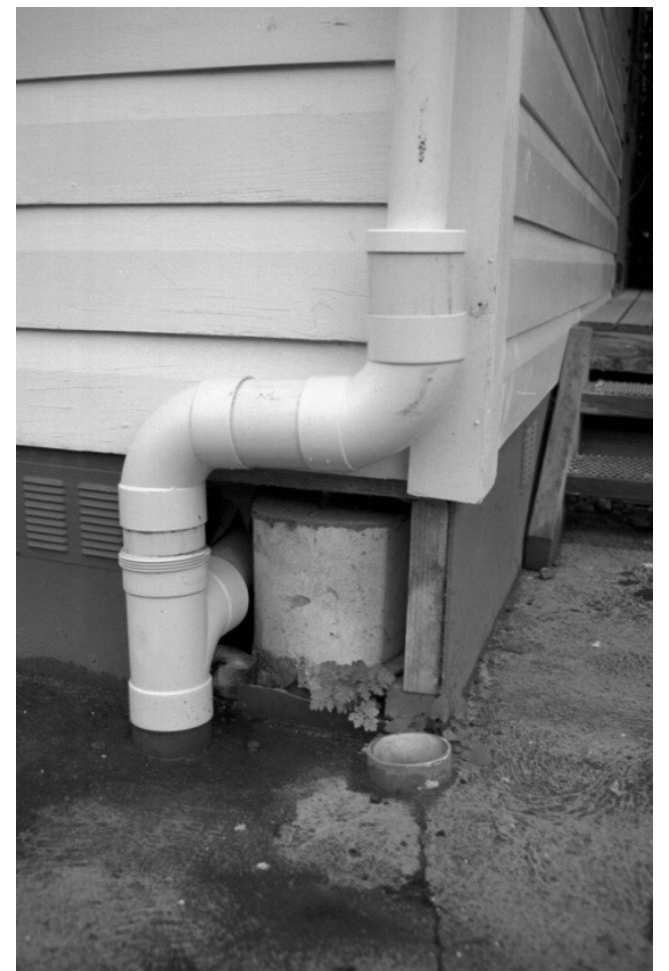

E13: 1MTT hostel relocated to Te Anau Holiday Park (Photo by the author)

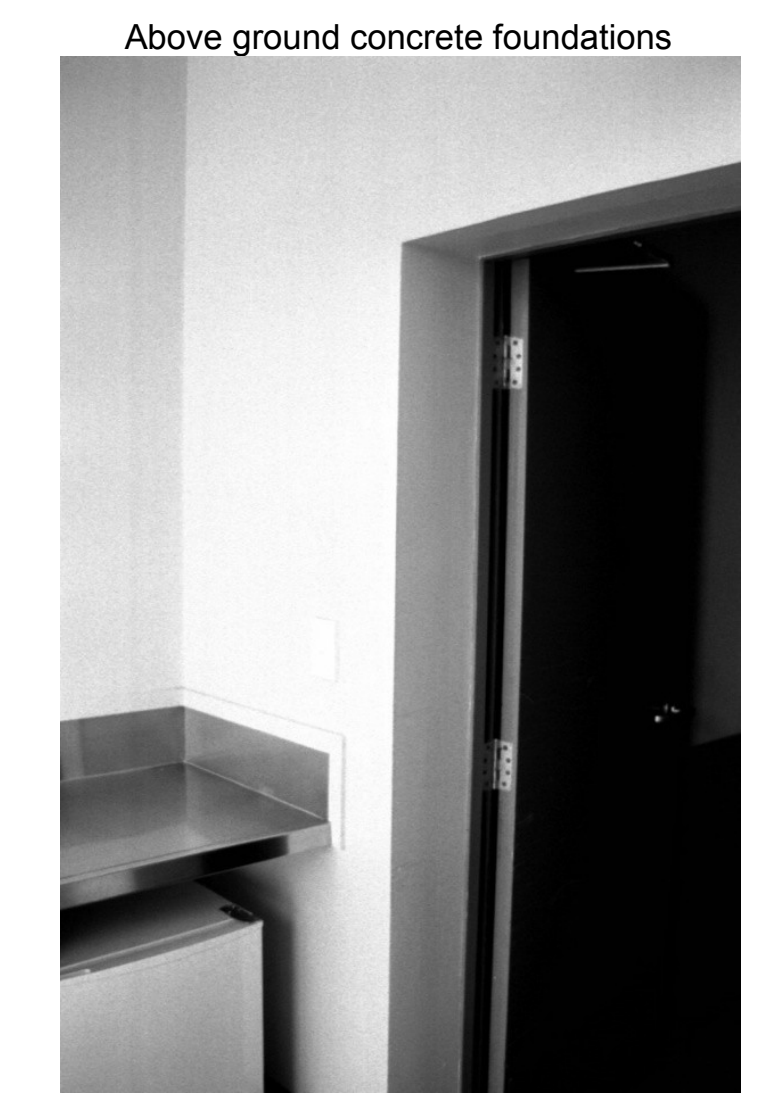

E14: 1MTT West Arm hostel at Te Anau Holiday Park (Photo by the author)

The thickness of the walls at the join of transportable hostel modules is visible here. A fire door has been fitted at the join and the double wall has been utilized to create fire and acoustic separation. 


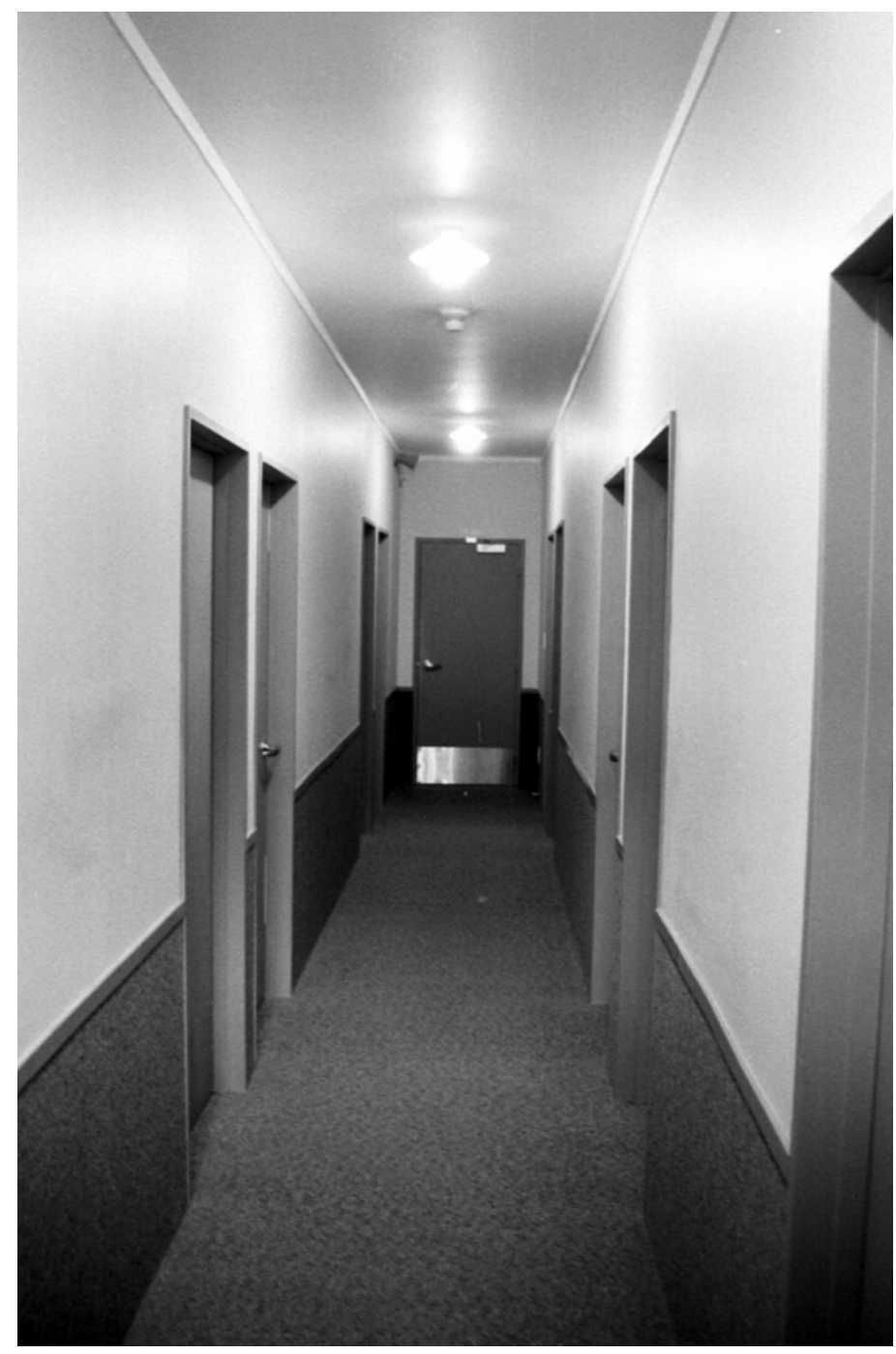

E15: 1MTT West Arm hostel at Te Anau Holiday Park (Photo by the author)

Sleeping quarters corridor 


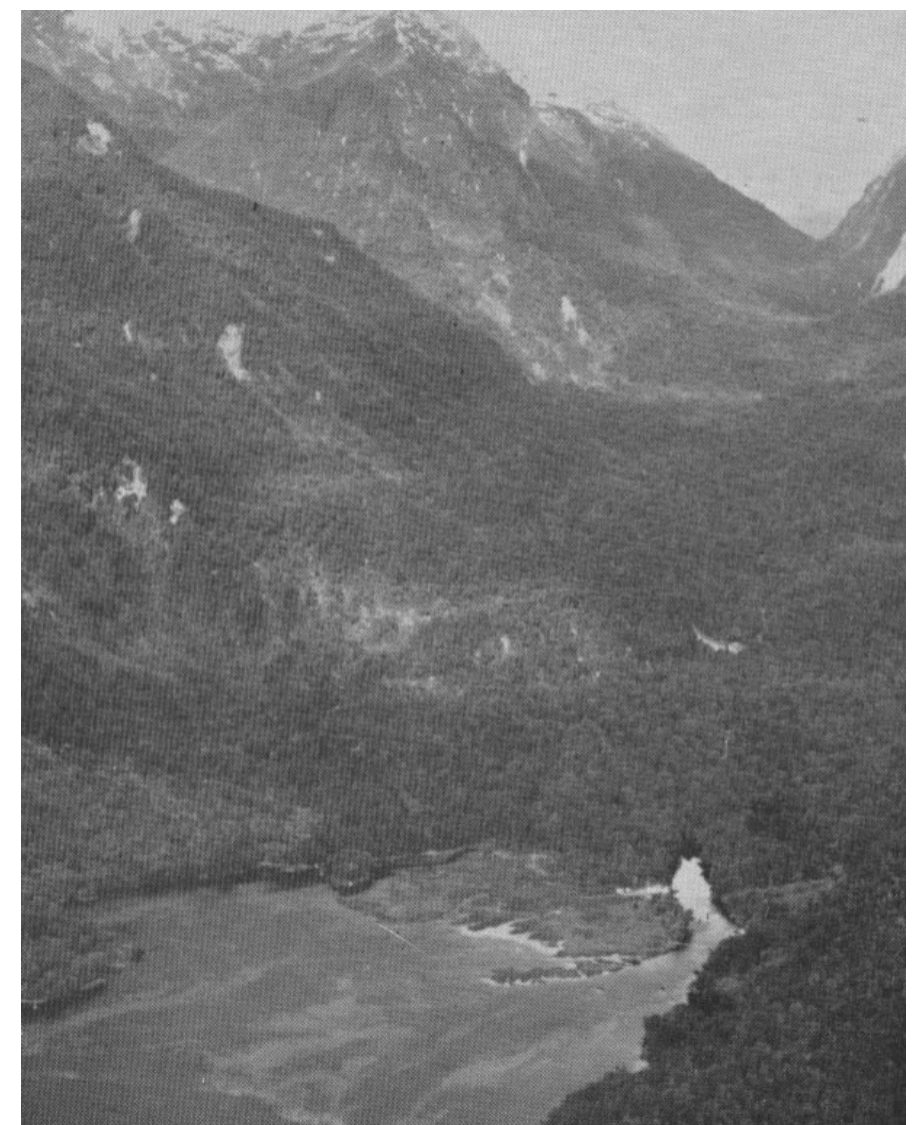

E16: Deep Cove prior to the beginning of construction (Photo by Ministry of Works and Development)

The vegetation here is very thick and the site is very damp (with up to 6 metres of rain per year). Run off comes straight down the steep slopes surrounding the bay on three sides and access was only possible via the fiord until the Wilmot Pass Road was constructed over the pass at right of the picture. 


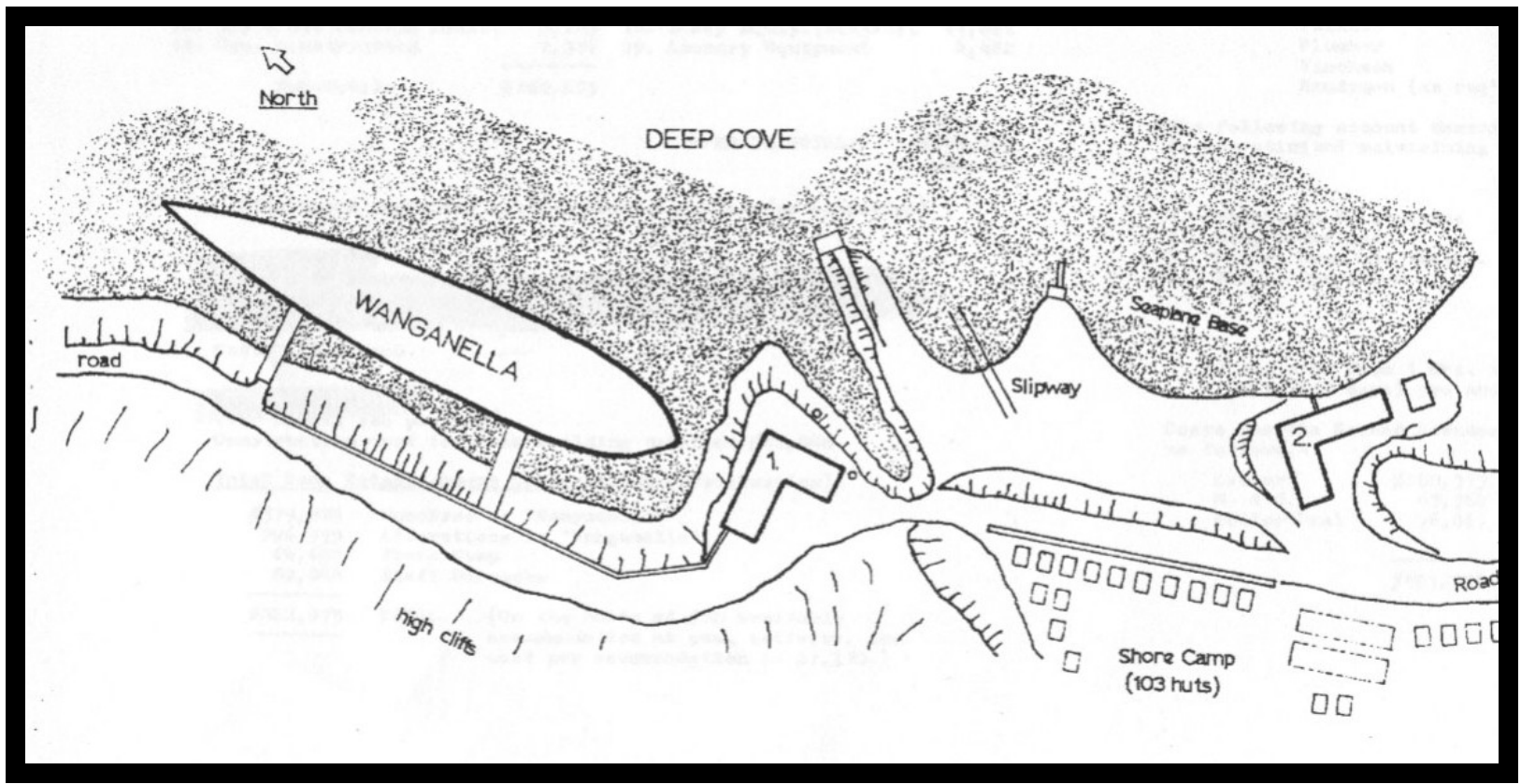

E17: Plan of Wanganella at permanent berth, Deep Cove

(Plan courtesy of Meridian Energy)

1.Change House

2.Staff hostel

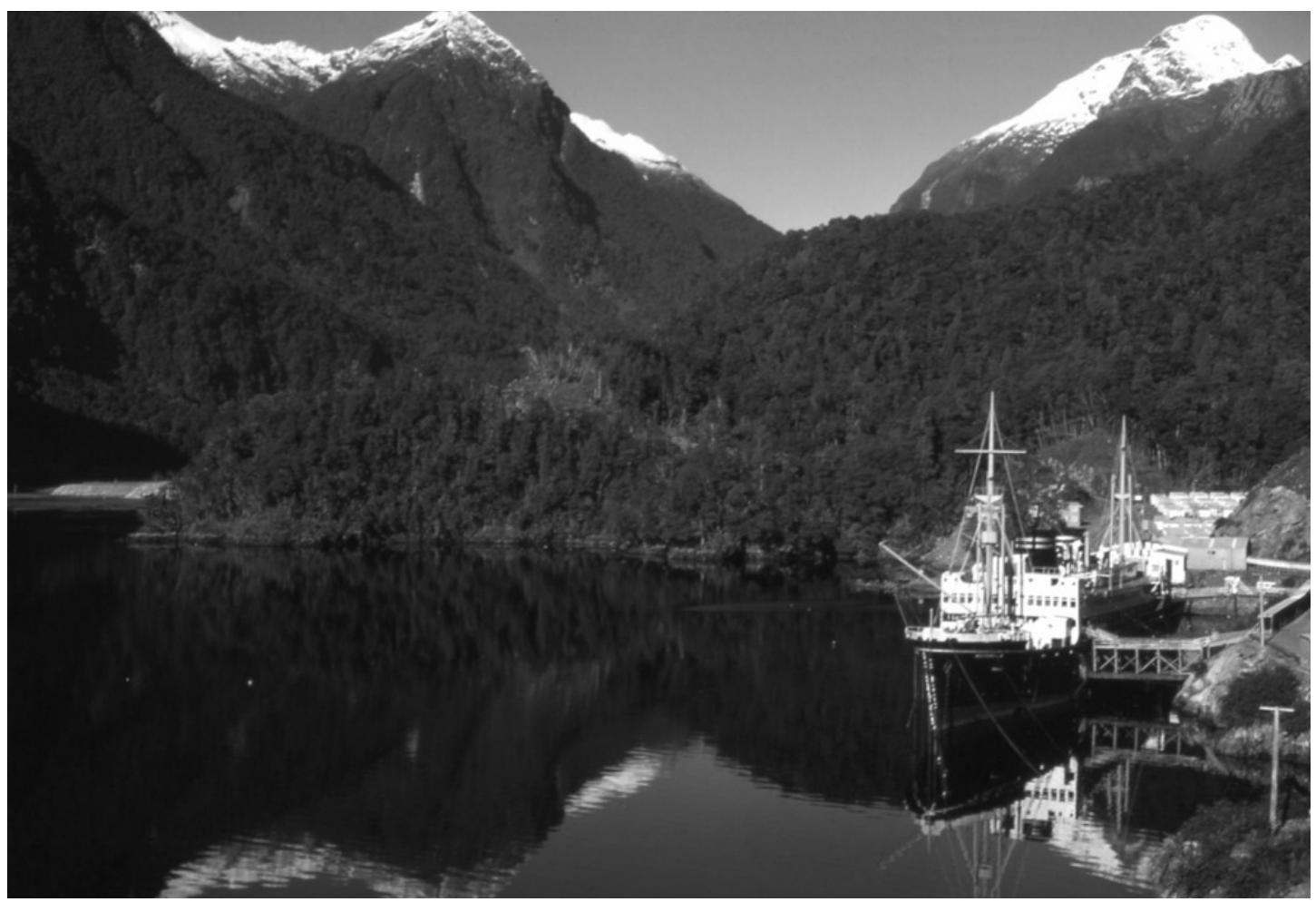

E18: 1MTT project at Deep Cove

(Photo by Ministry of Works and Development, courtesy of Meridian Energy)

This photo shows the Wanganella in place with the 1MTT project site to the far left. The Shore Camp huts are visible behind the Wanganella - note that all accommodations are for singles only, with no allowance made for accompanying families.

Directly behind the Wanganella the change house is just visible.

This photo clearly shows the thickness of vegetation and the snow on the peaks. The pass around the centre of the photo is where the Wilmot Pass Road is to eventually be constructed. 


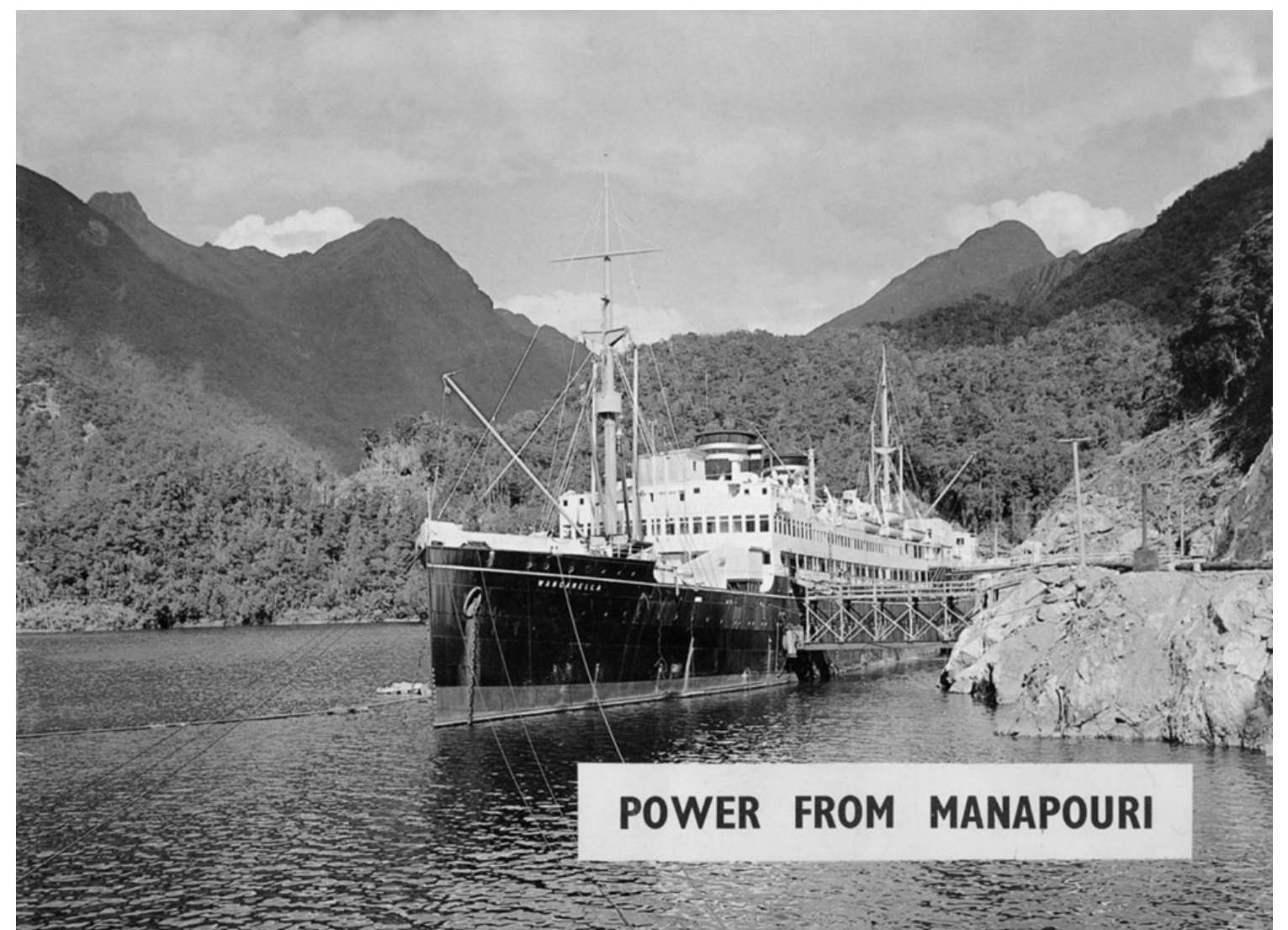

E19: Wanaganella at permanent berth in Deep Cove

(Photo by Ministry of Works and Development, courtesy of Meridian Energy)

This is self-contained transportable accommodation, but there were some problems - the only access (prior to the Wilmot Pass Road) was via water, making access difficult during bad weather; bad weather also made the accommodations uncomfortable in large swells; the metal structure required a lot of heating from the ship's generator to keep the occupants warm, particularly when they had spent their shifts working in wet conditions; creating the permanent berth had required significant earthworks in a National Park. 


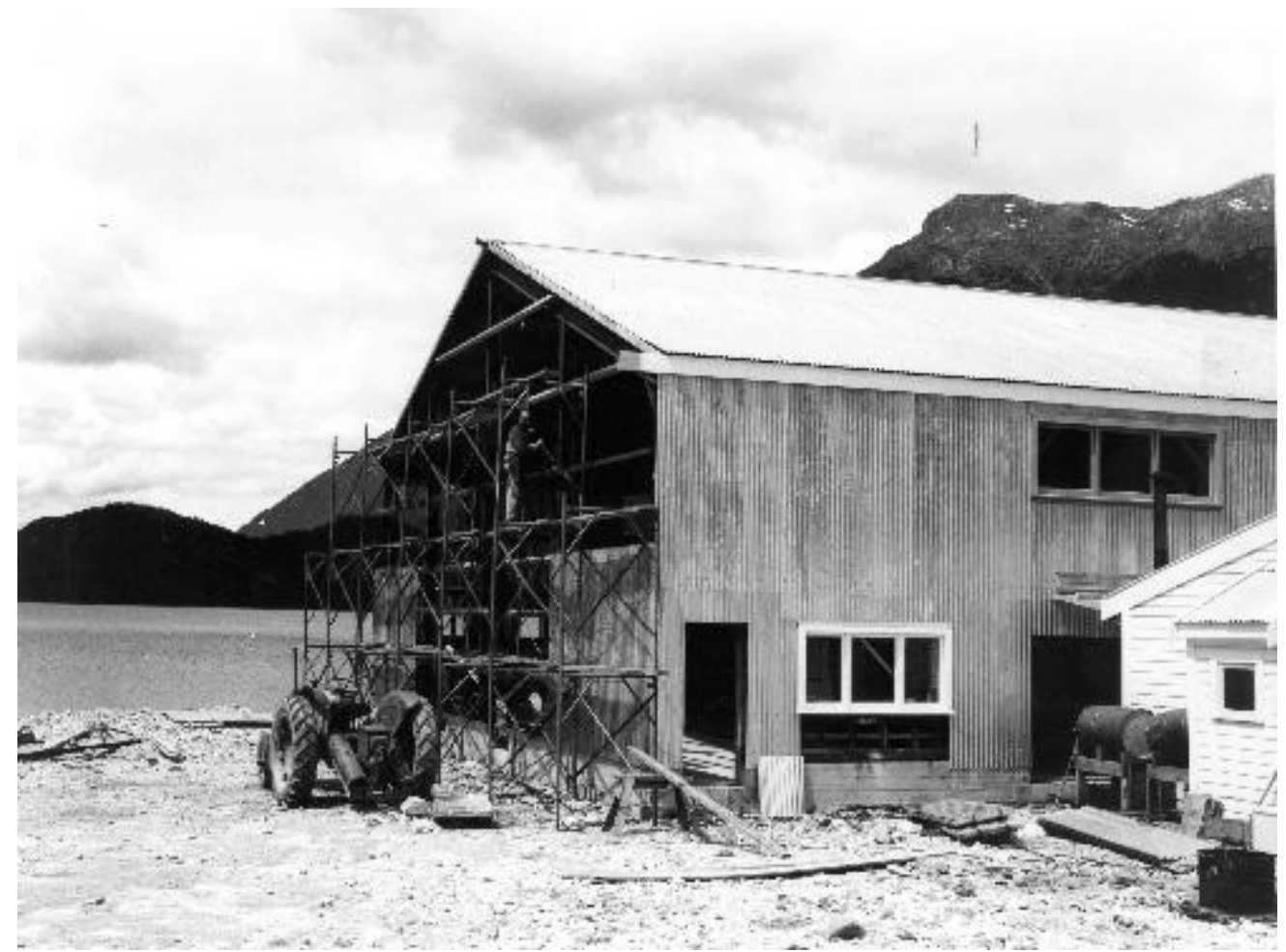

E20: 1MTT staff hostel at Deep Cove under construction

(Photo by Ministry of Works and Development, courtesy of Meridian Energy)

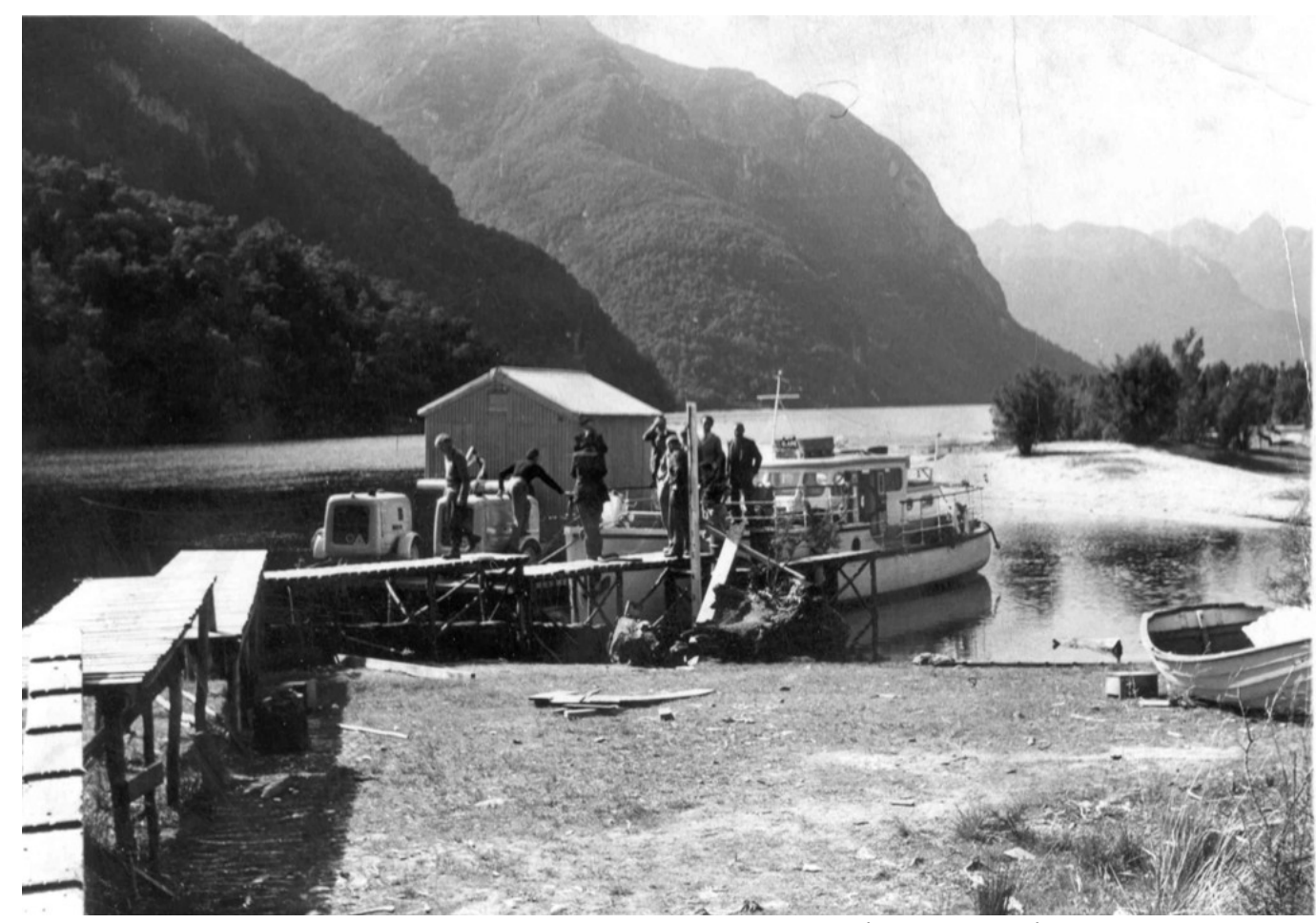

E21: 1MTT Deep Cove Shore Camp hut being barged in

(Photo by Ministry of Works and Development, courtesy of Meridian Energy) 


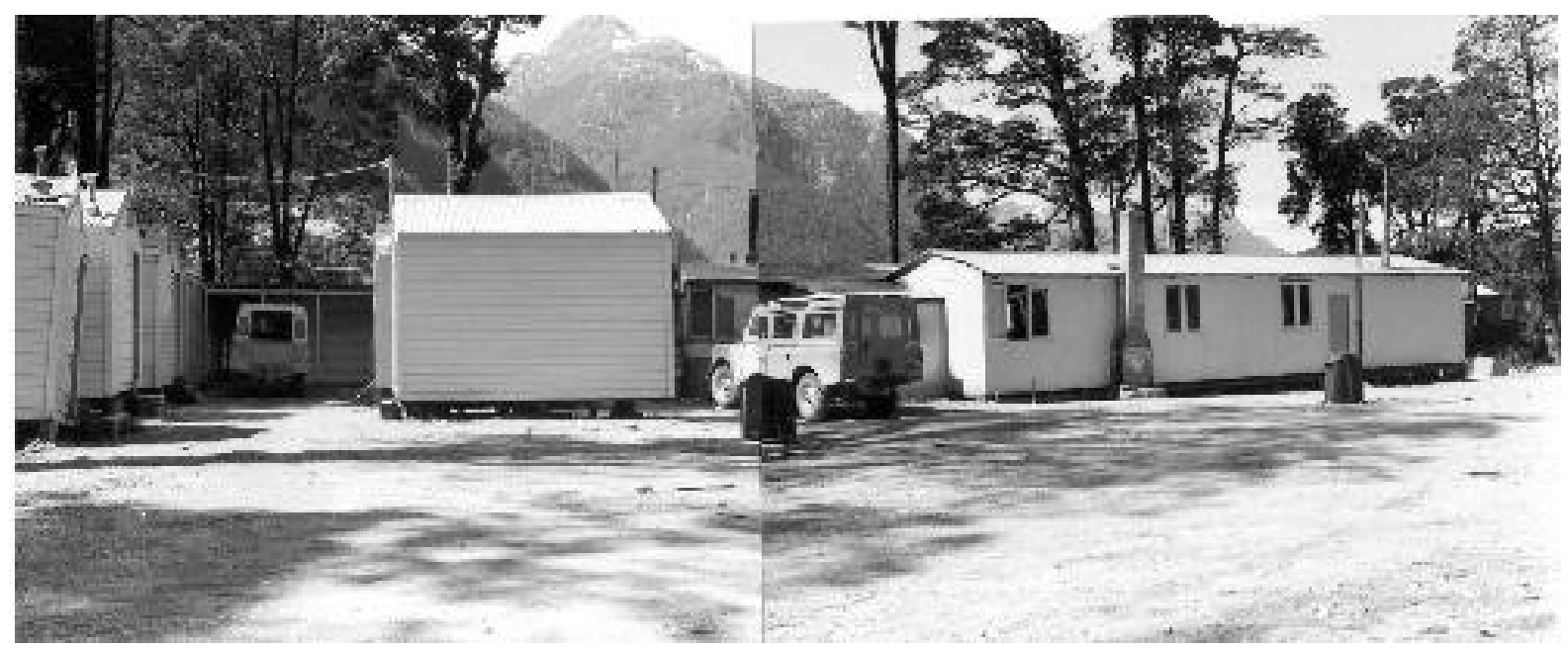

E22: 1MTT Shore camp at Deep Cove

(Photo by Ministry of Works and Development, courtesy of Meridian Energy)

Note the brick chimneys on the staff building to the right

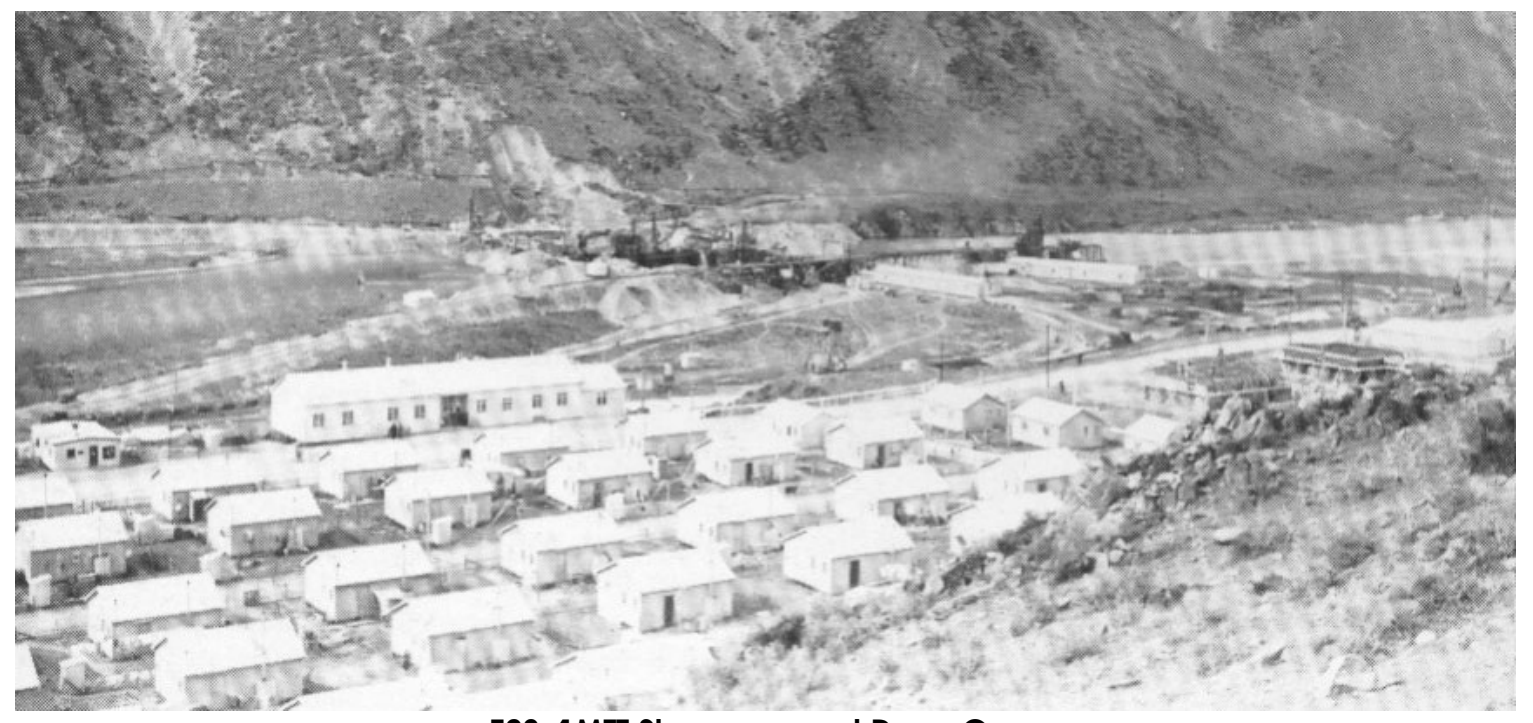

E23: 1MTT Shore camp at Deep Cove

(Photo by Ministry of Works and Development, courtesy of Meridian Energy) 


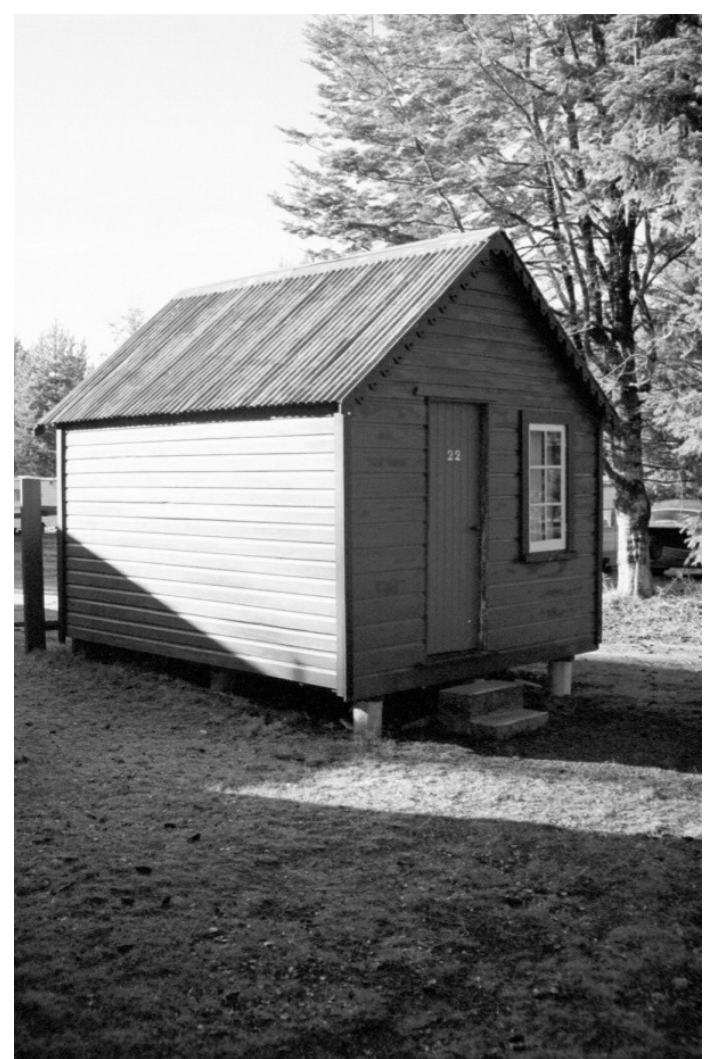

E24: 1MTT hut at Manapouri Holiday Park (Photo by the author)

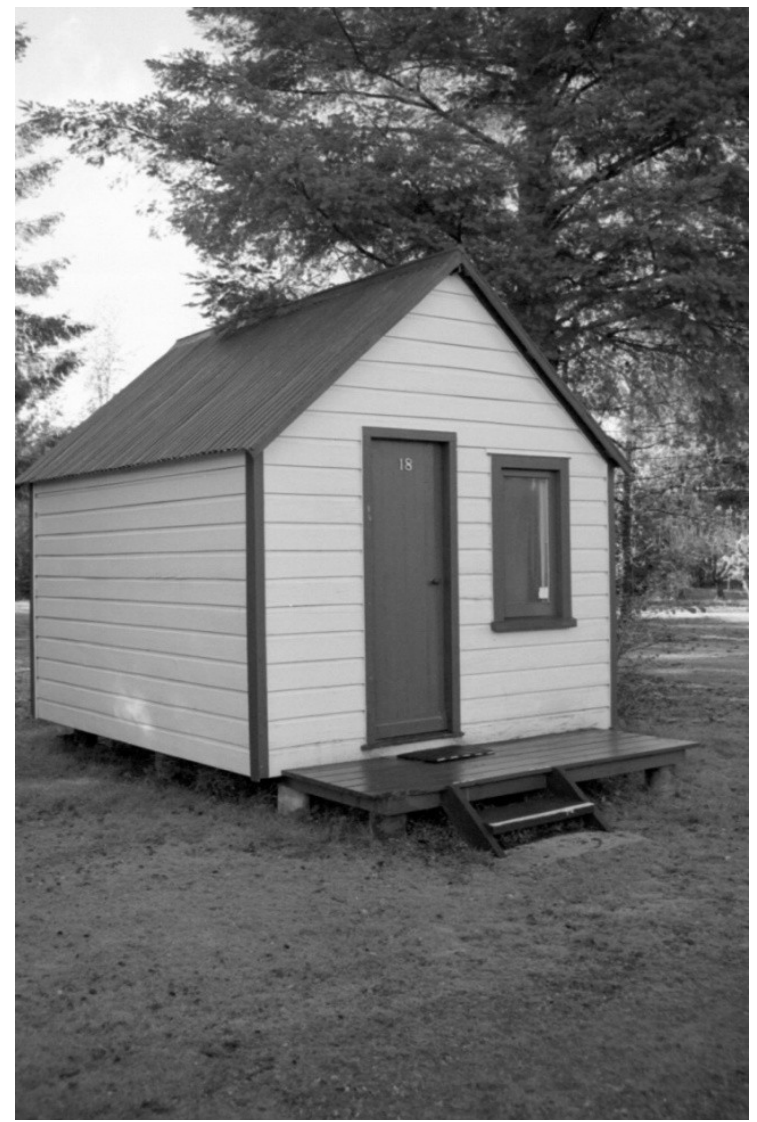

E25: 1MTT hut at Manapouri Holiday Park (Photo by the author) 


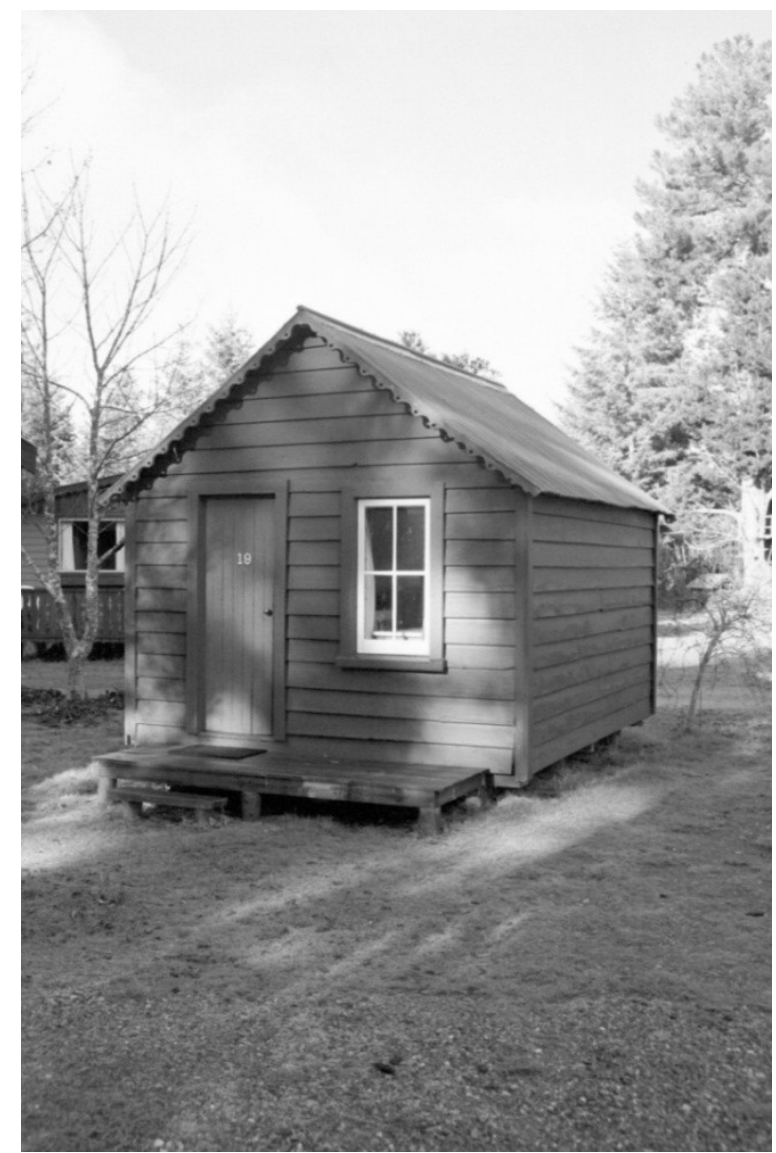

E26: 1MTT hut at Manapouri Holiday Park

(Photo by the author)

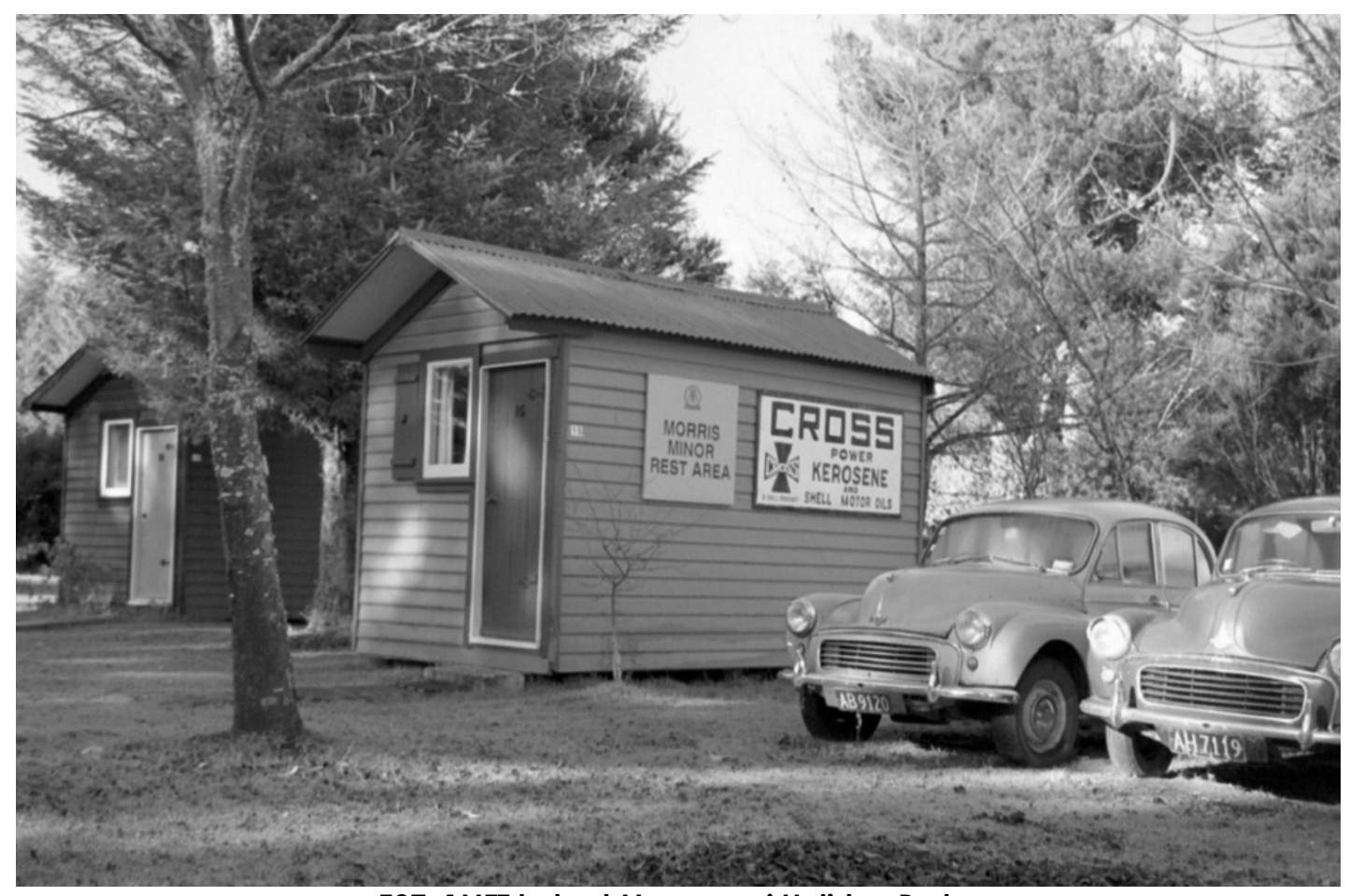

E27: 1MTT huts at Manapouri Holiday Park

(Photo by the author) 


\section{F: Twizel}

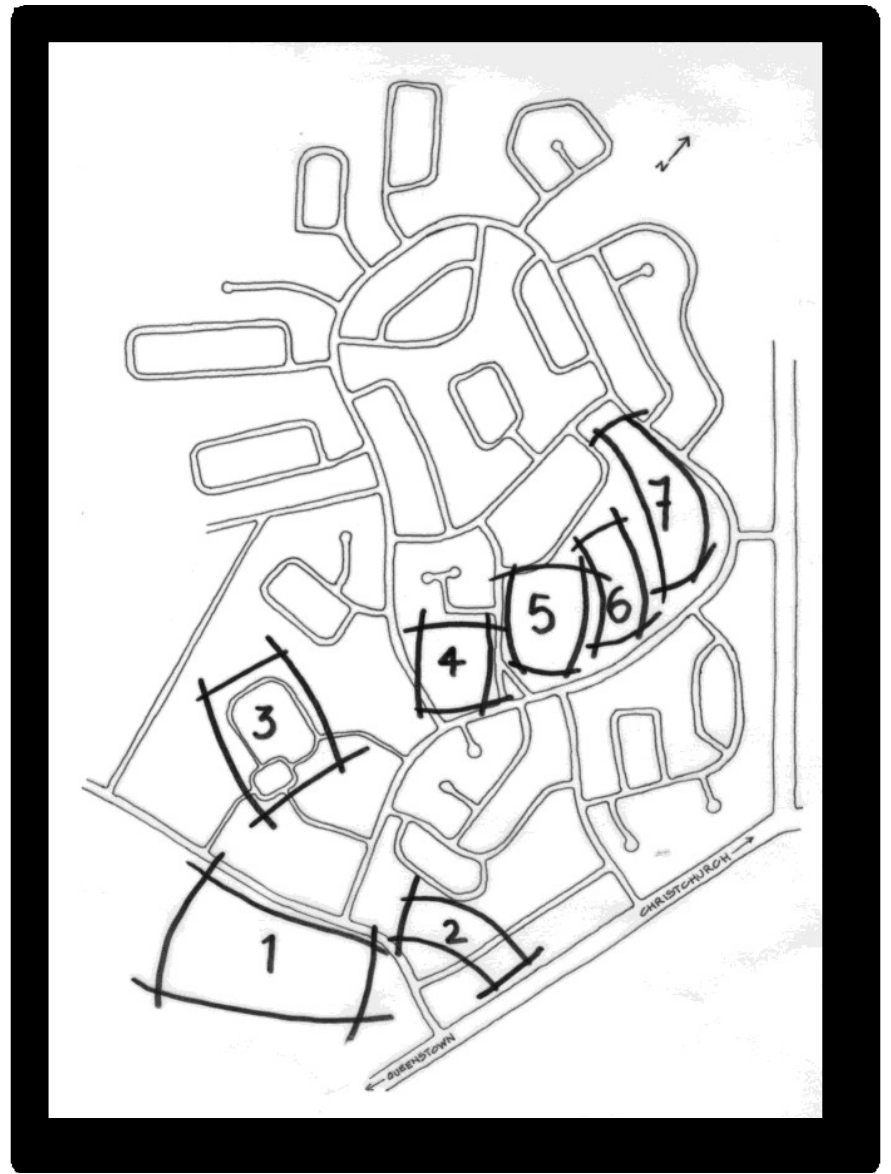

F1: Twizel town plan, 1977

1.Industrial Area

2.Tourist Facilities

3.Singlemens' Camp and Canteen

4.Staff Hostel

5.Shops and Community Services

6.Schools and Sports Facilities

7.Sports Fields

Note: the only changes to the town plan since 1977 are that the industrial area has diminished and the tourist facilities have expanded 


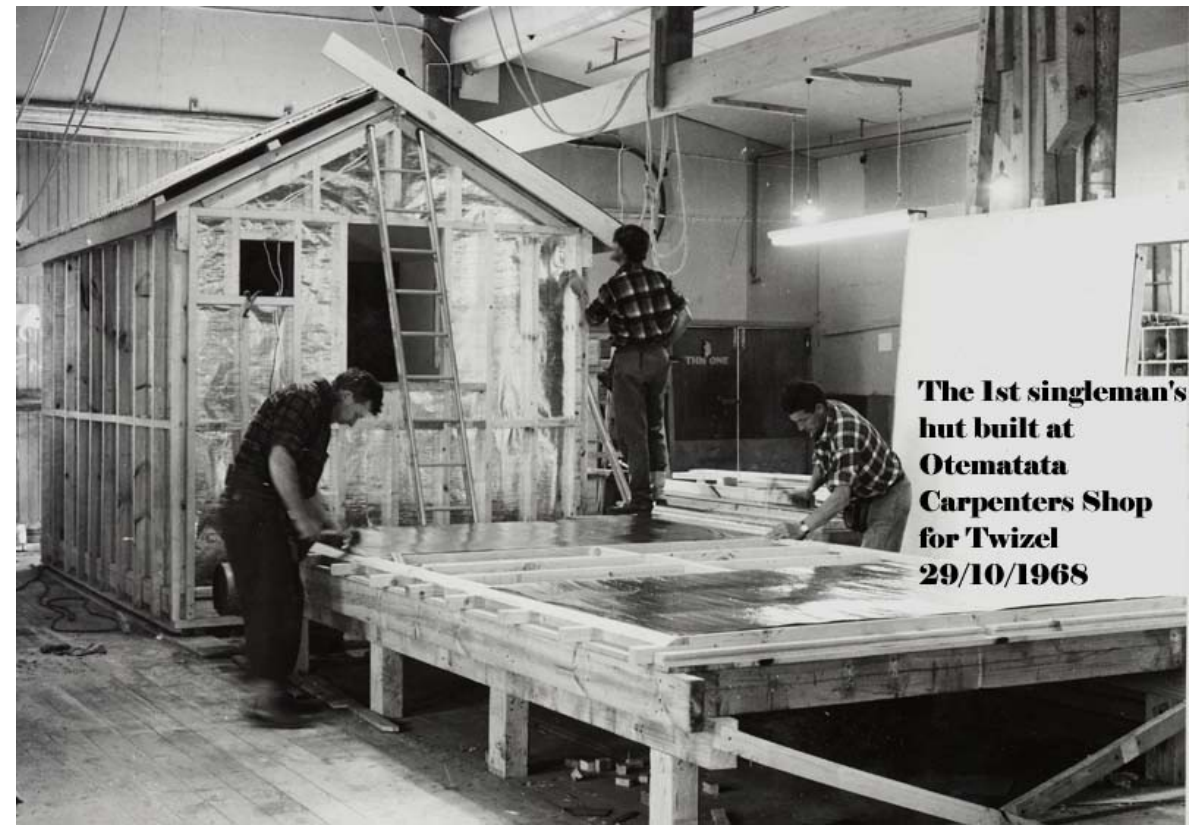

F2: (Photo courtesy of Southern Alps Photos)

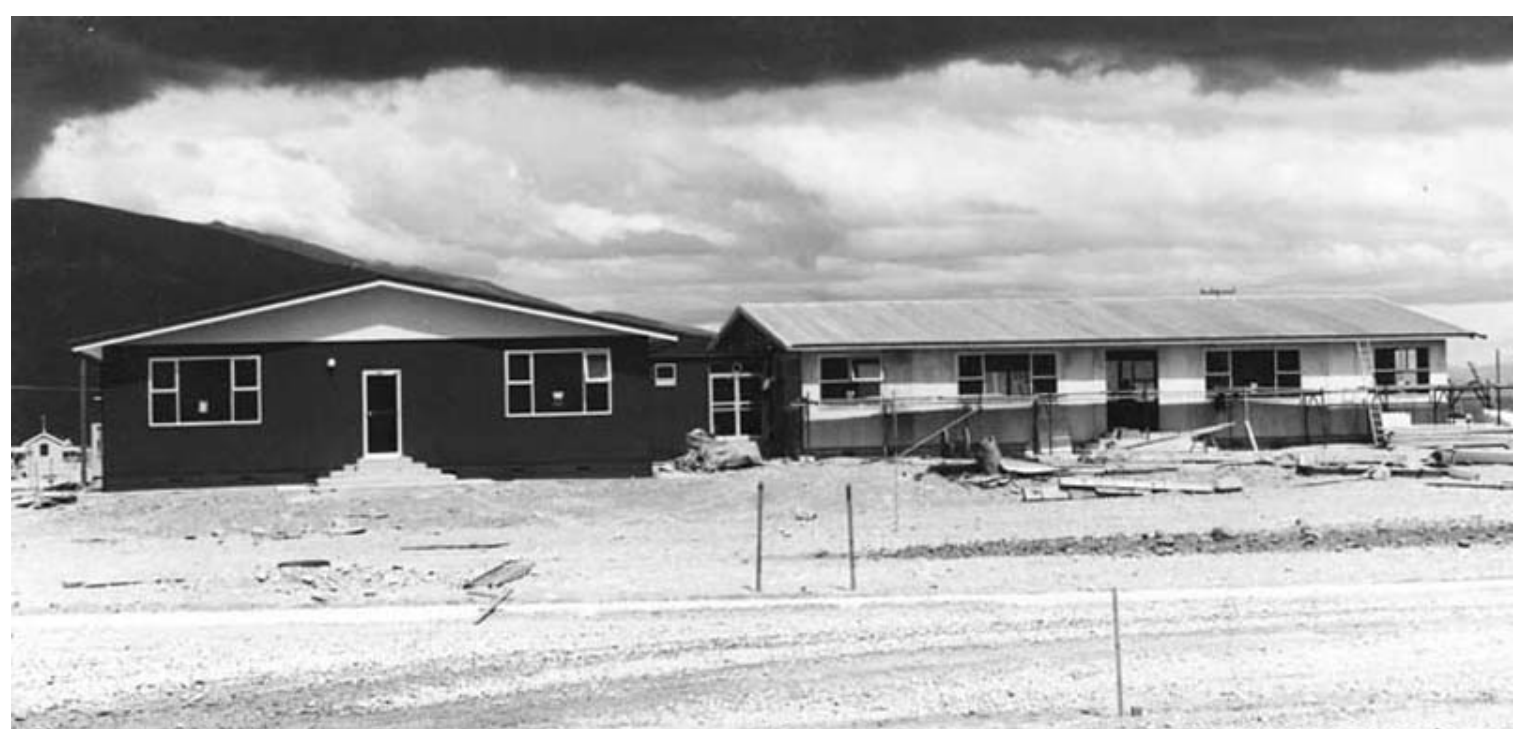

Single Men's Canteen

$13 / 02 / 1970$

(Photo courtesy of Southern Alps Photos) 


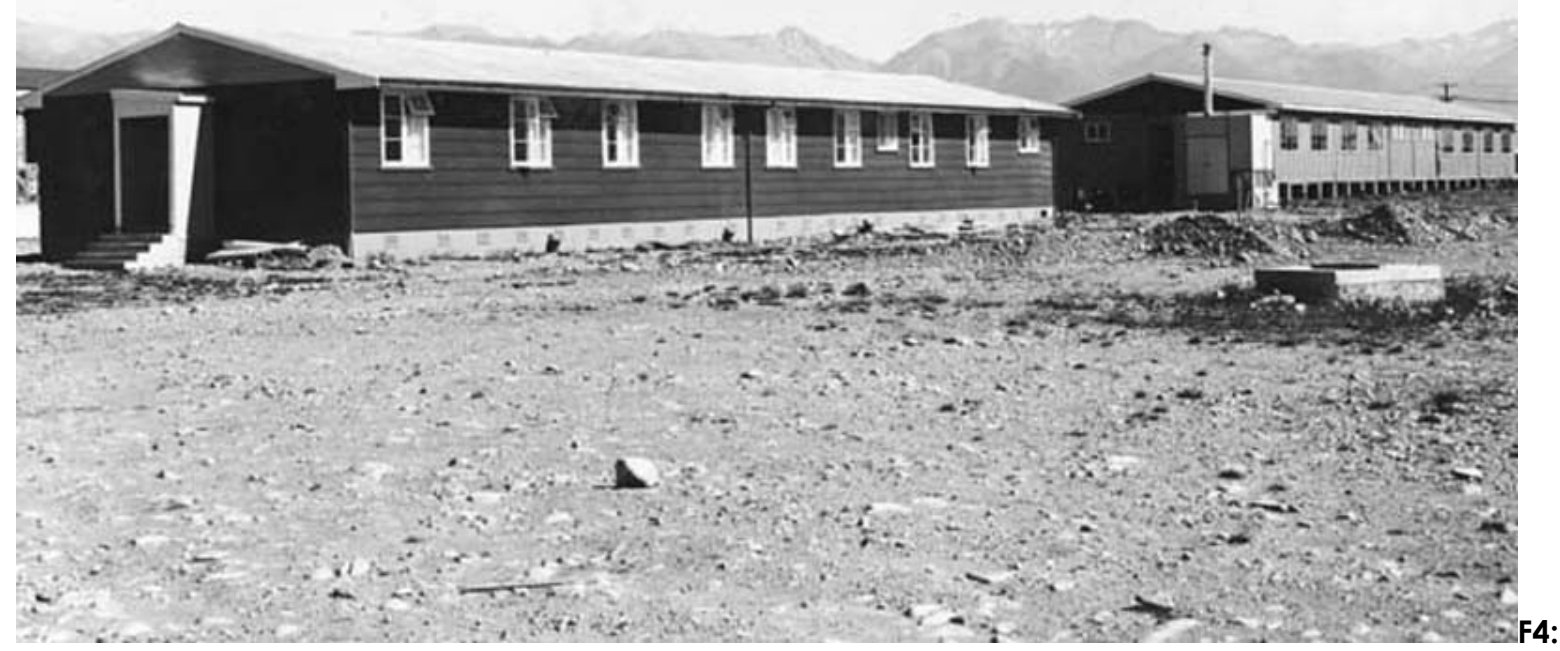

(Photo courtesy of Southern Alps Photos)

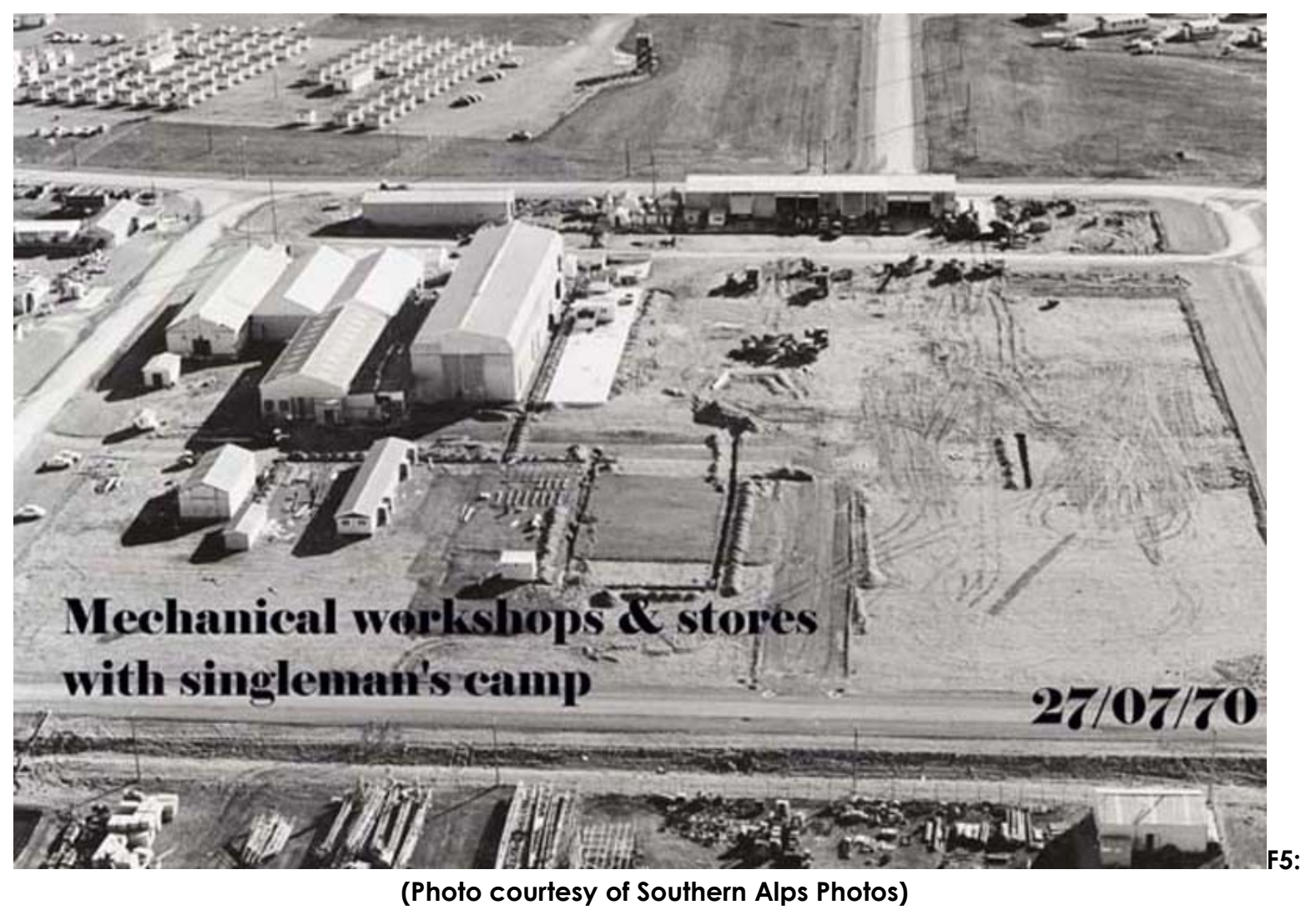




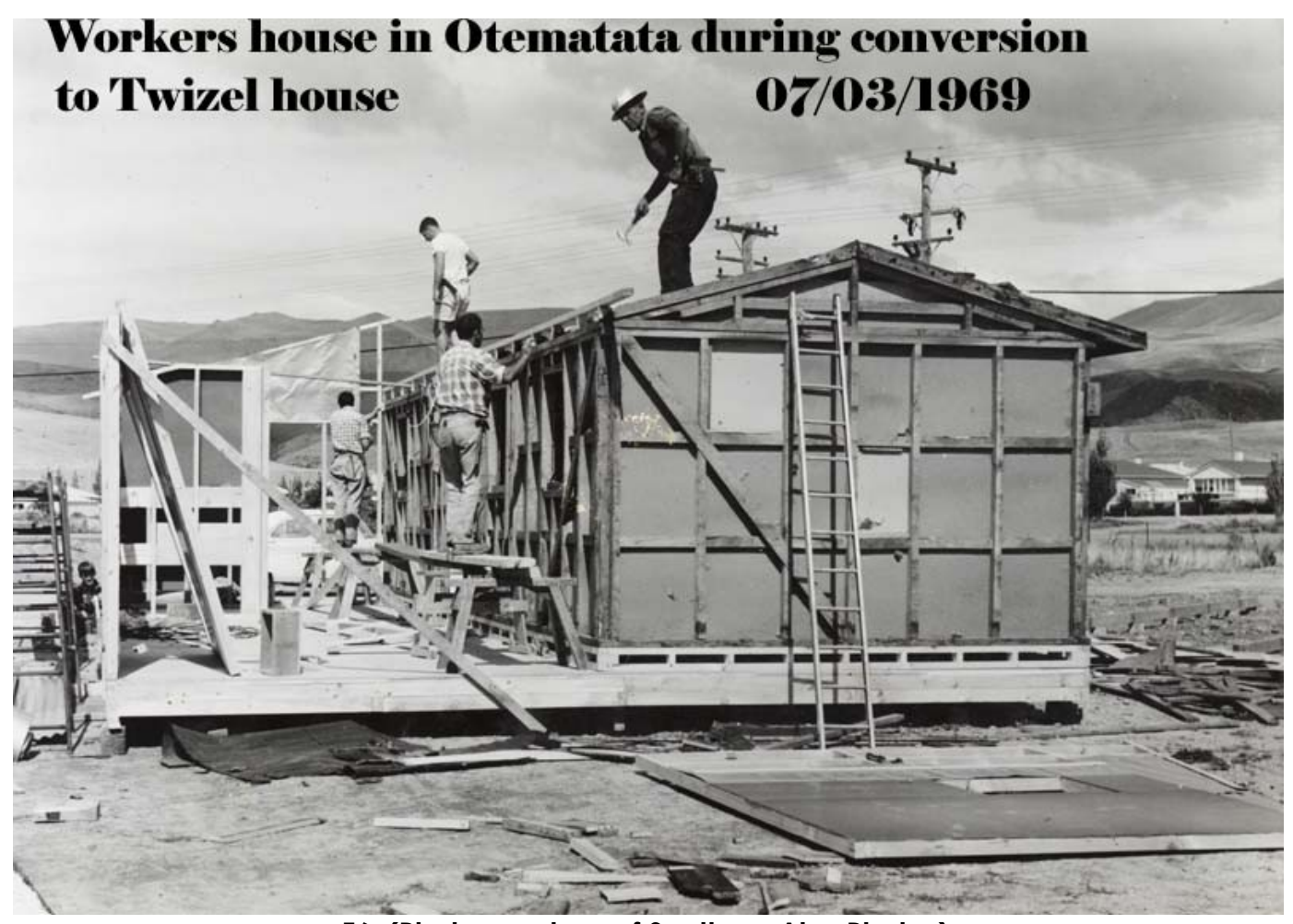

F6: (Photo courtesy of Southern Alps Photos)

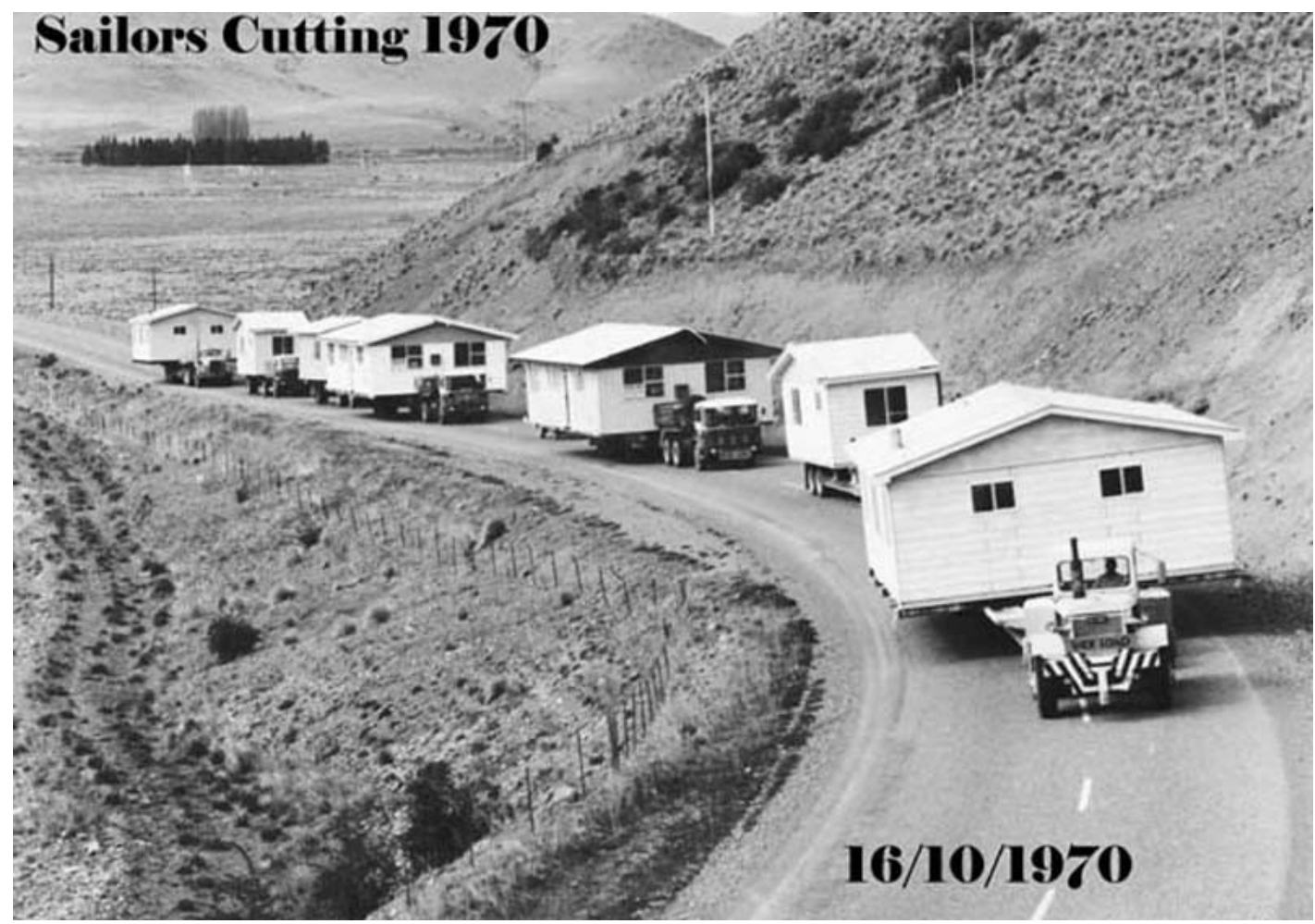

F7: (Photo courtesy of Southern Alps Photos) 


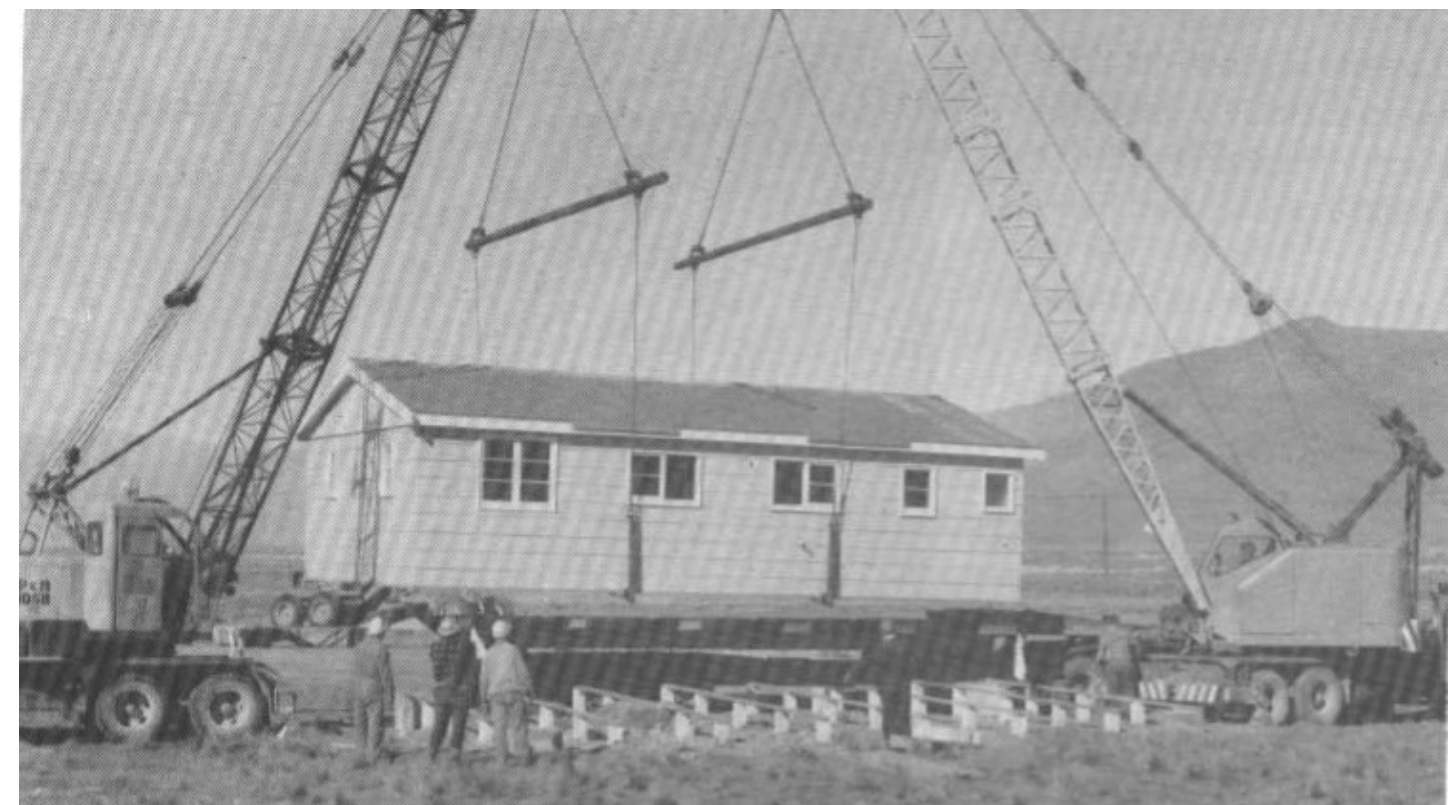

F8: First

house being lifted into place at Twizel, April 29, 1969

(Photo from Sheridan, Marion, Dam Dwellers, p 138)

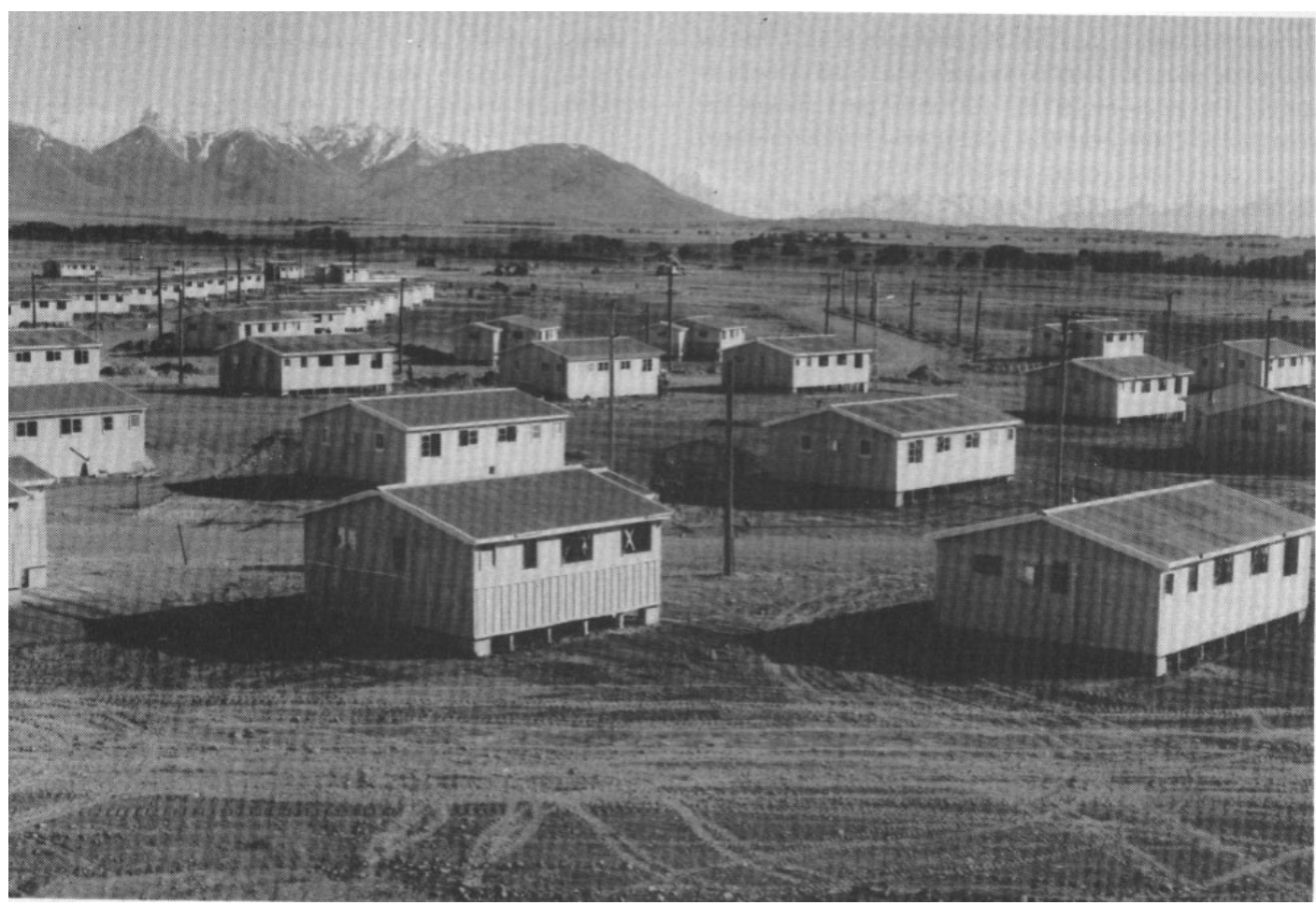

in place at Twizel

F9: Houses

(Photo courtesy of Southern Alps Photos) 


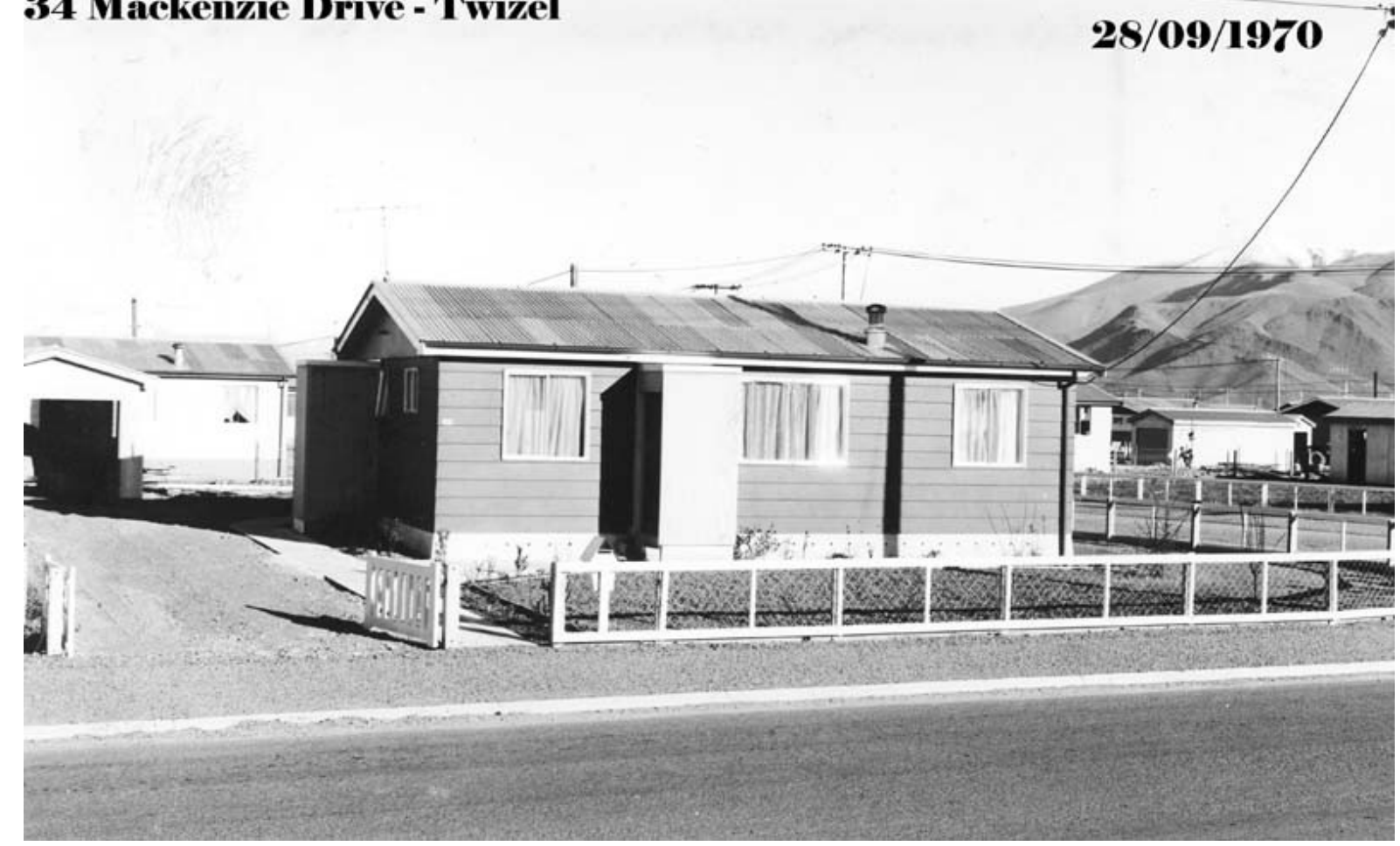

F10: (Photo courtesy of Southern Alps Photos)

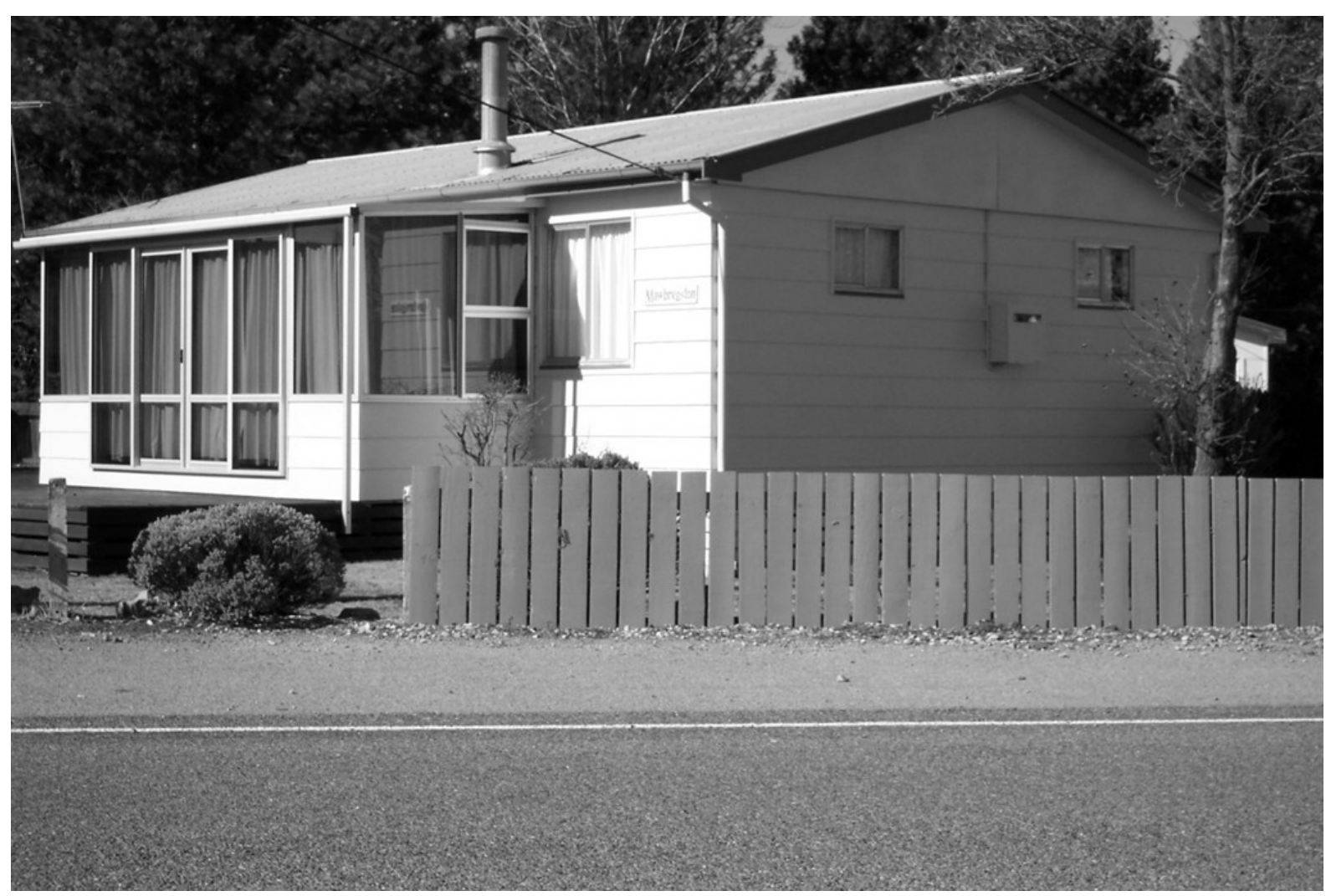

F11: House at Twizel, 2007

(Photo by the author)

A porch and aluminium windows have been added to the entry to this house 


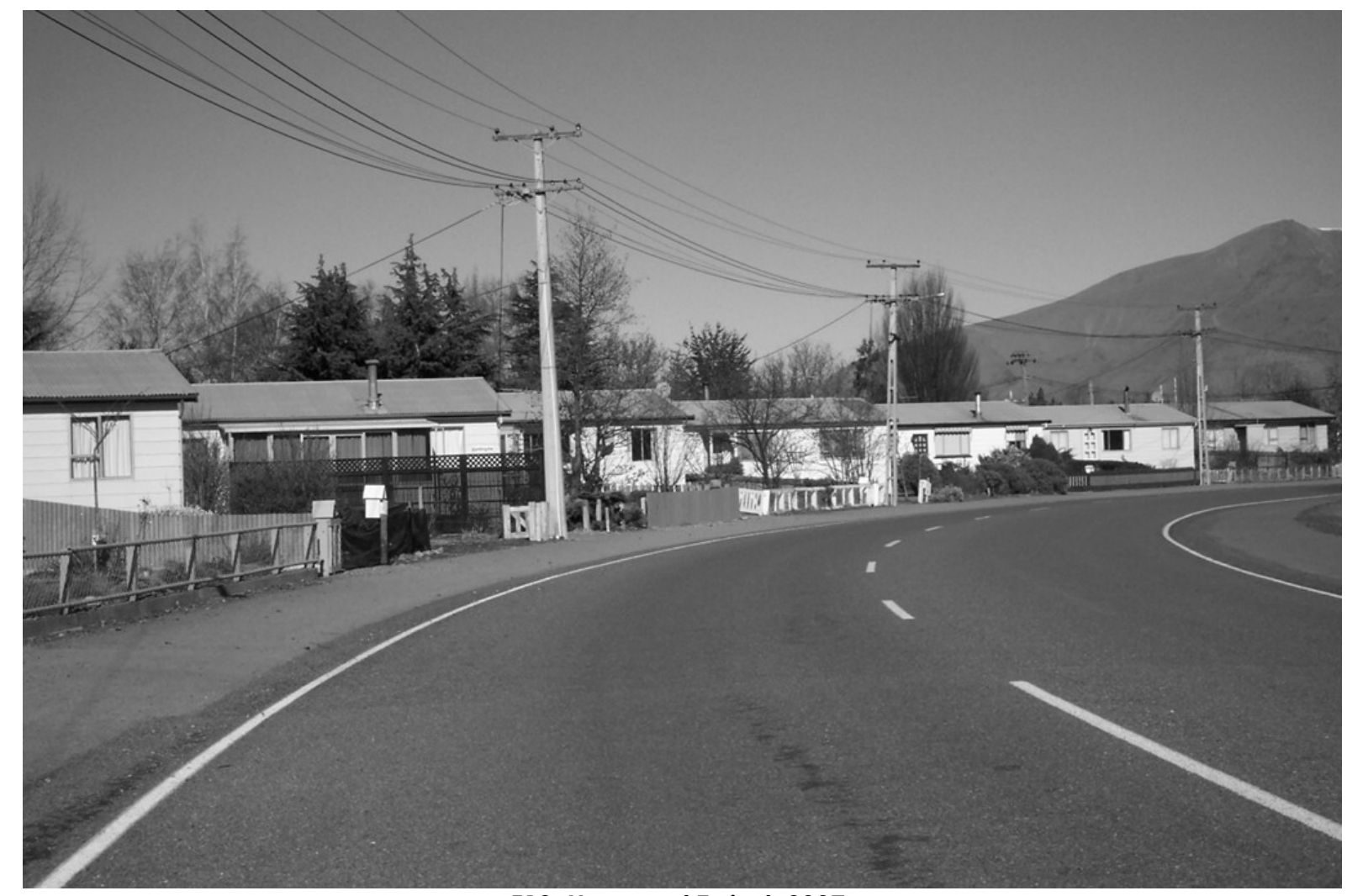

F12: Houses at Twizel, 2007

(Photo by the author)

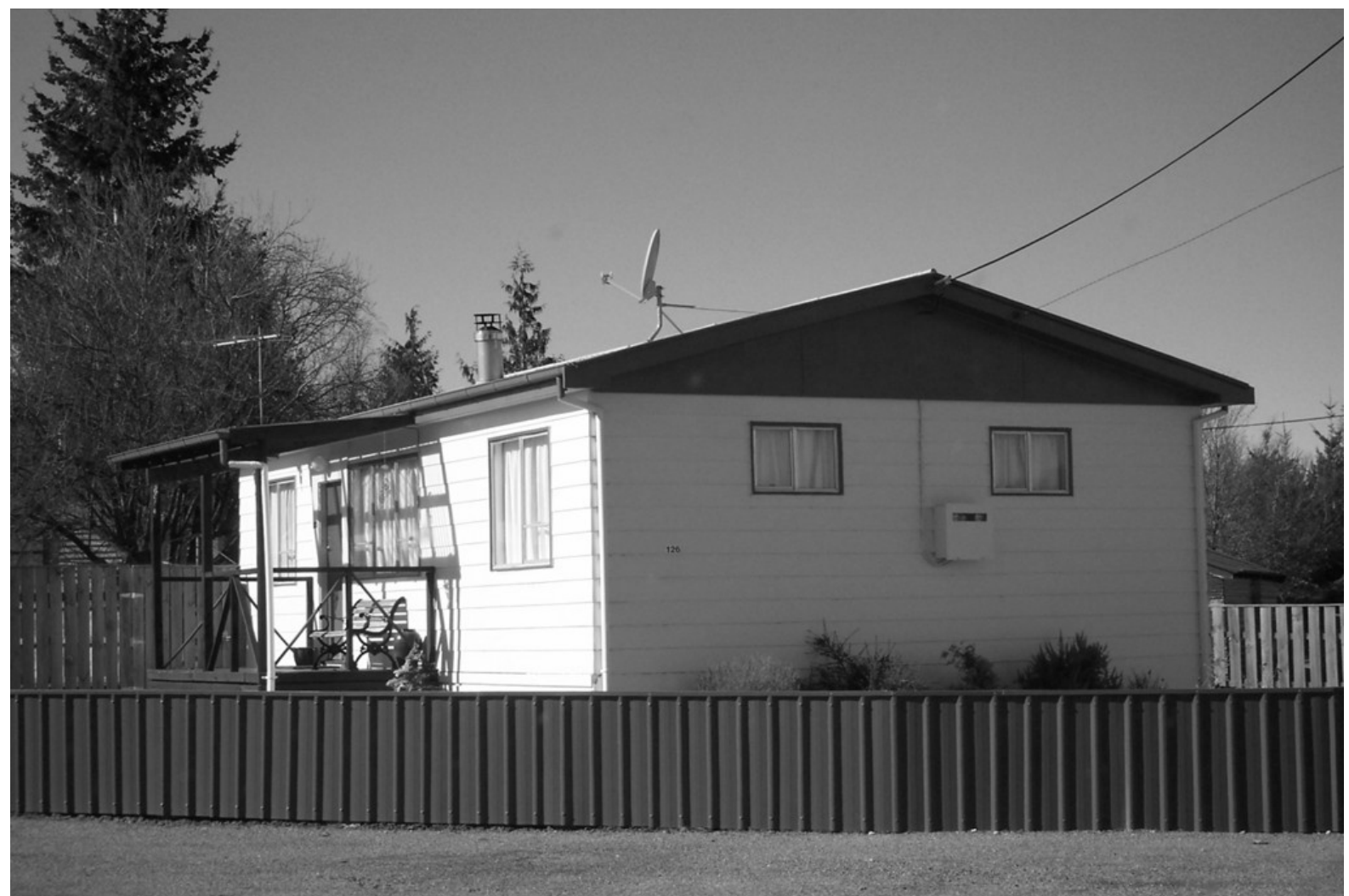

F13: House at Twizel, 2007

(Photo by the author)

A porch and aluminium windows have been added to this house 


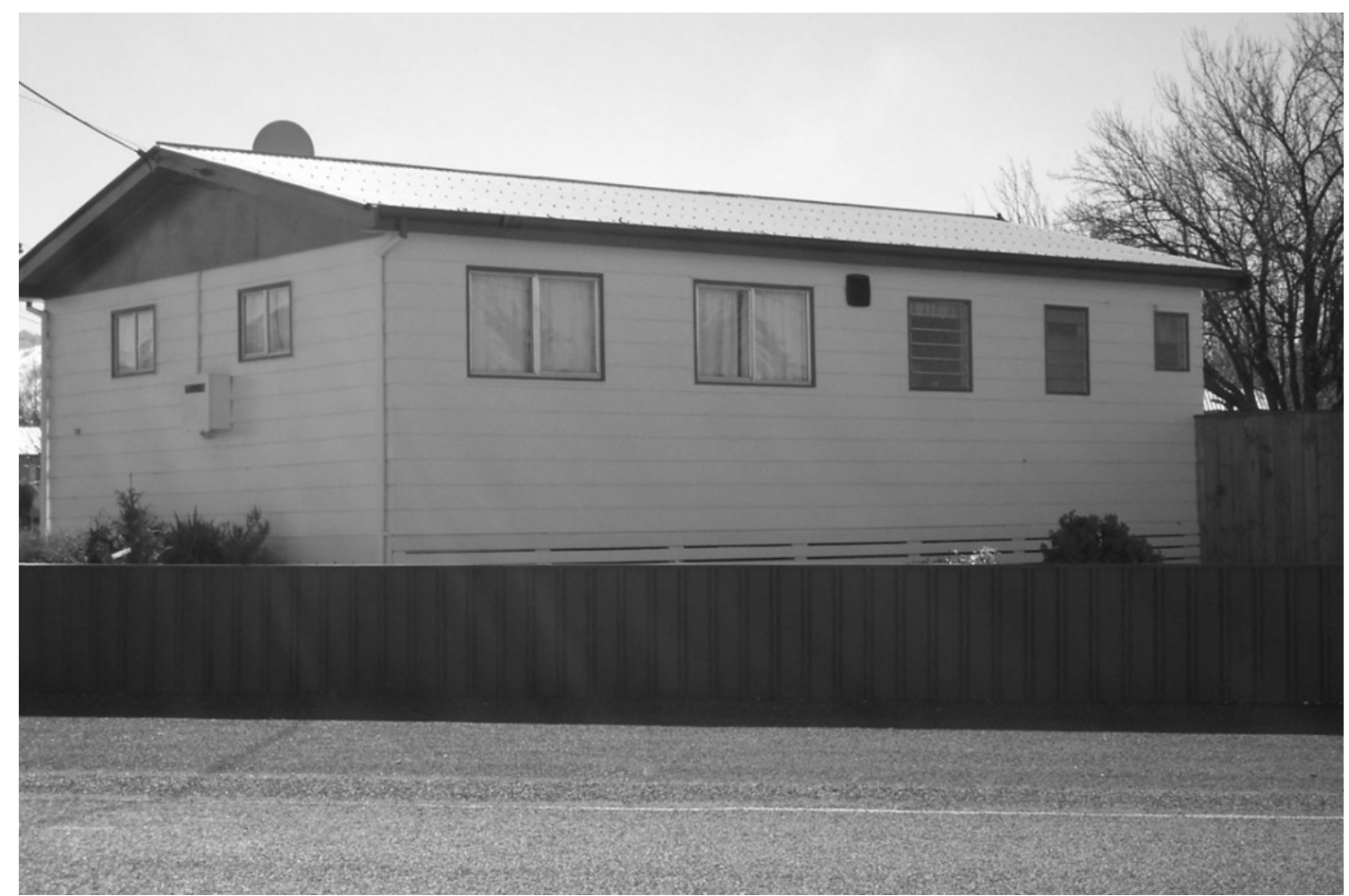

F14: House at Twizel, 2007

(Photo by the author)

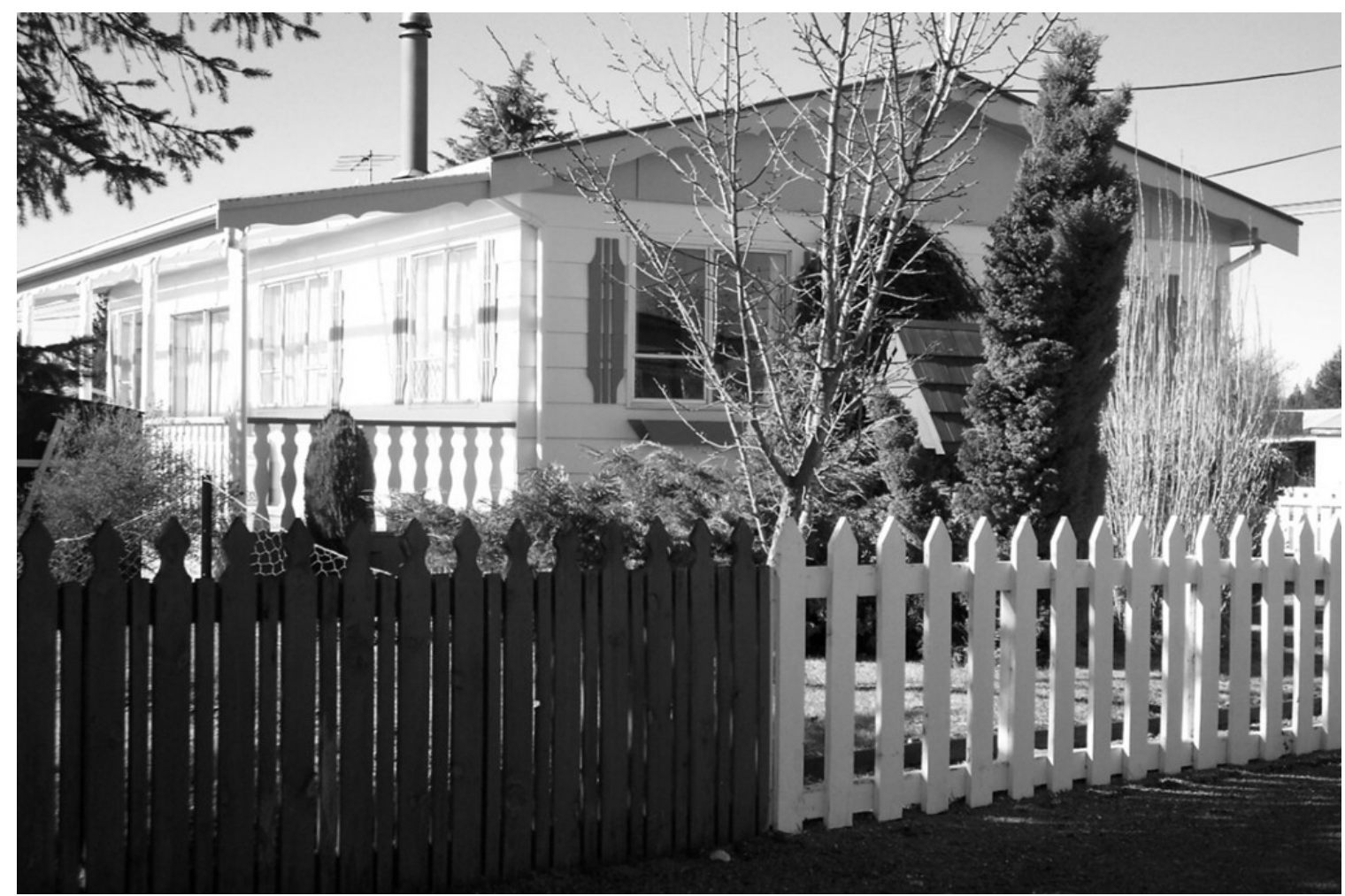

F15: House at Twizel, 2007

(Photo by the author)

A verandah has been added to this house and the windows have been changed to aluminium. Solid fuel heating has been installed and various 'stick-on' decorations have been added (such as false shutters). 


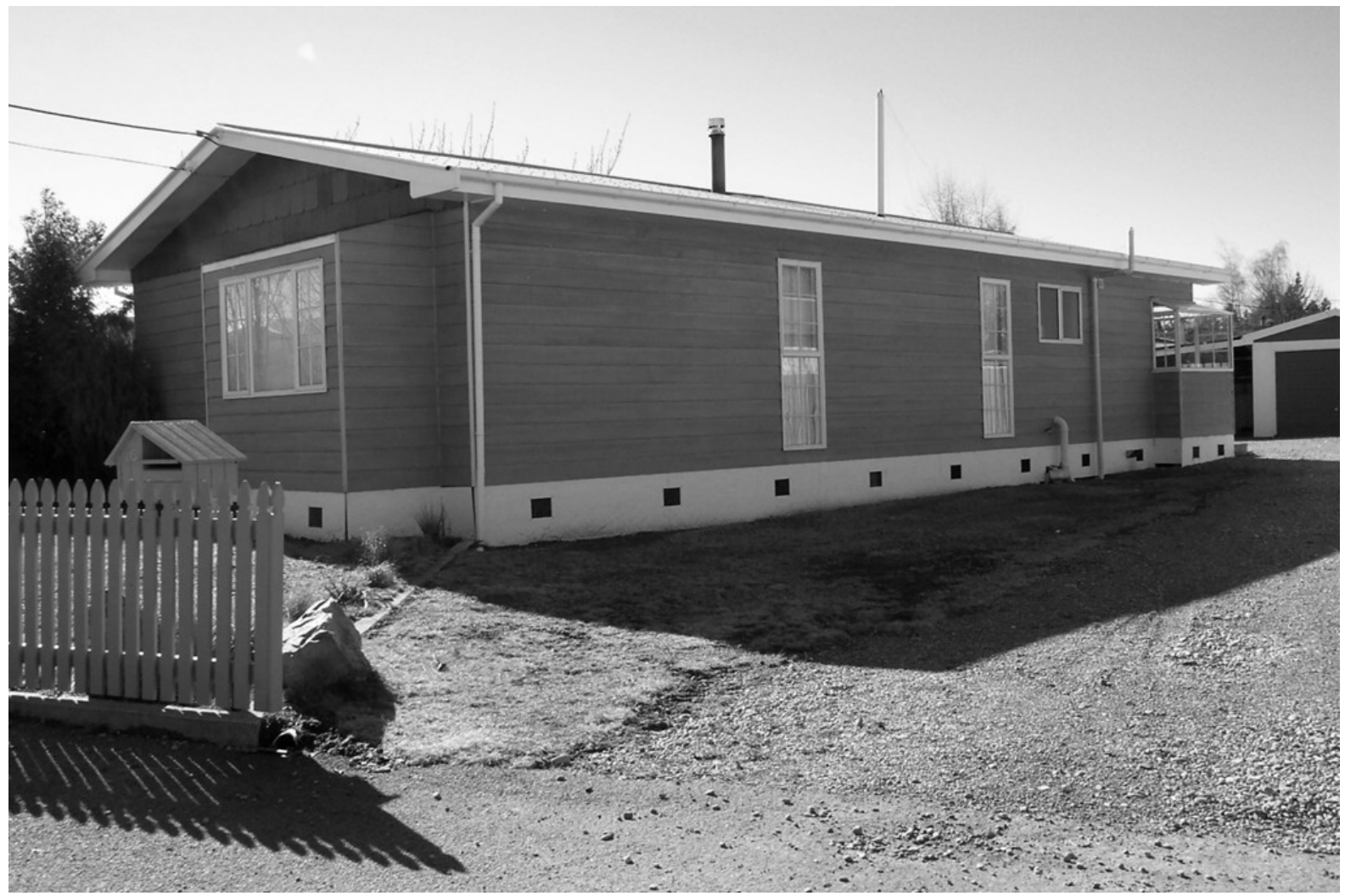

F16: House at Twizel, 2007

(Photo by the author)

This house has had the cladding changed and has had covers added to the bottom of the walls to hide the temporary nature of the foundations. The windows have been replaced with aluminium joinery and an extension has been added to each end of the house. 


\section{G: Cromwell}

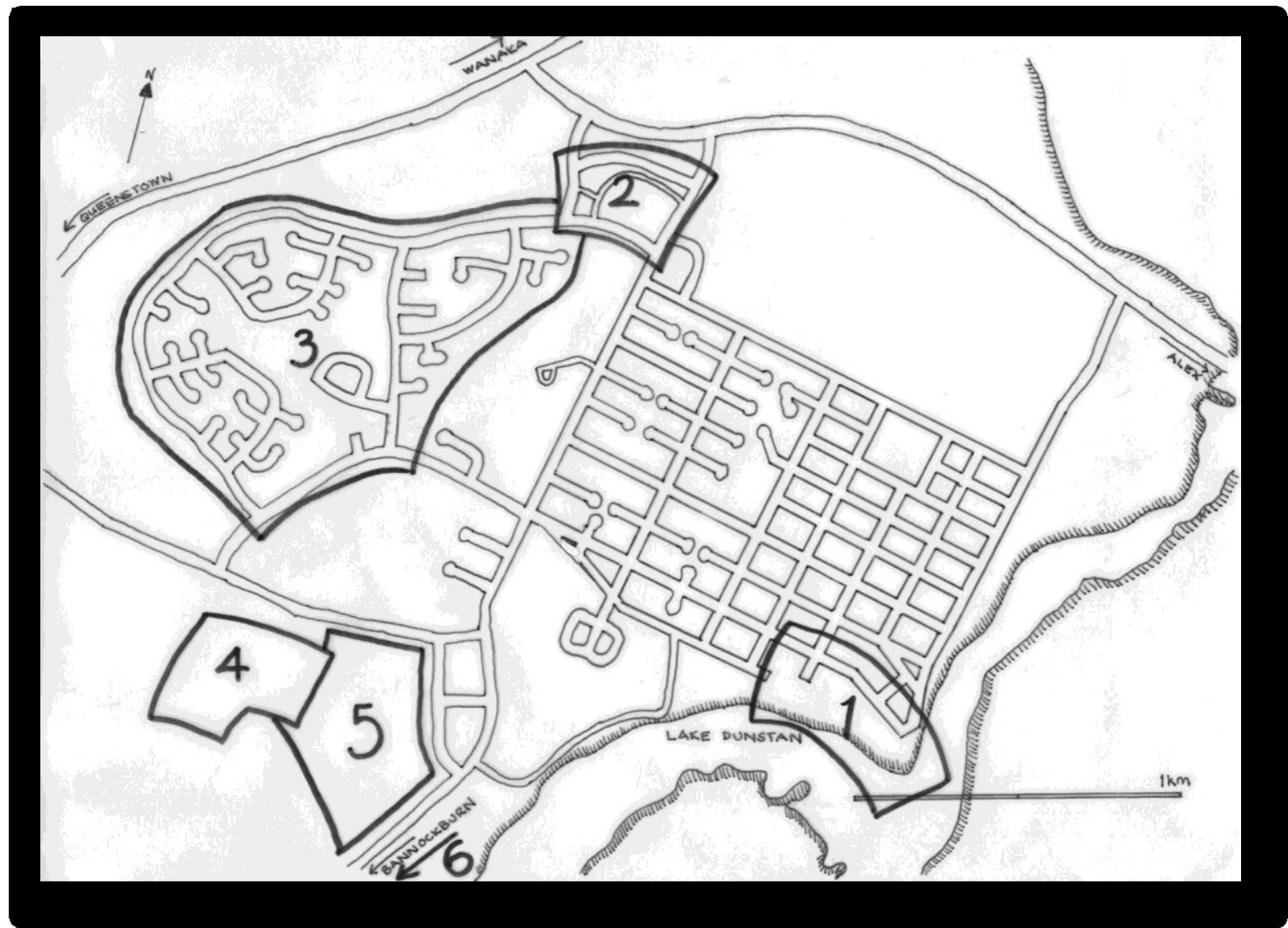

G1: Cromwell town plan

1 - old shopping area

2 - new shopping area

3 - new housing area and twizel transportable houses

4 - project office and zublins hostels

5 - project industrial area

6- singlemens' huts 


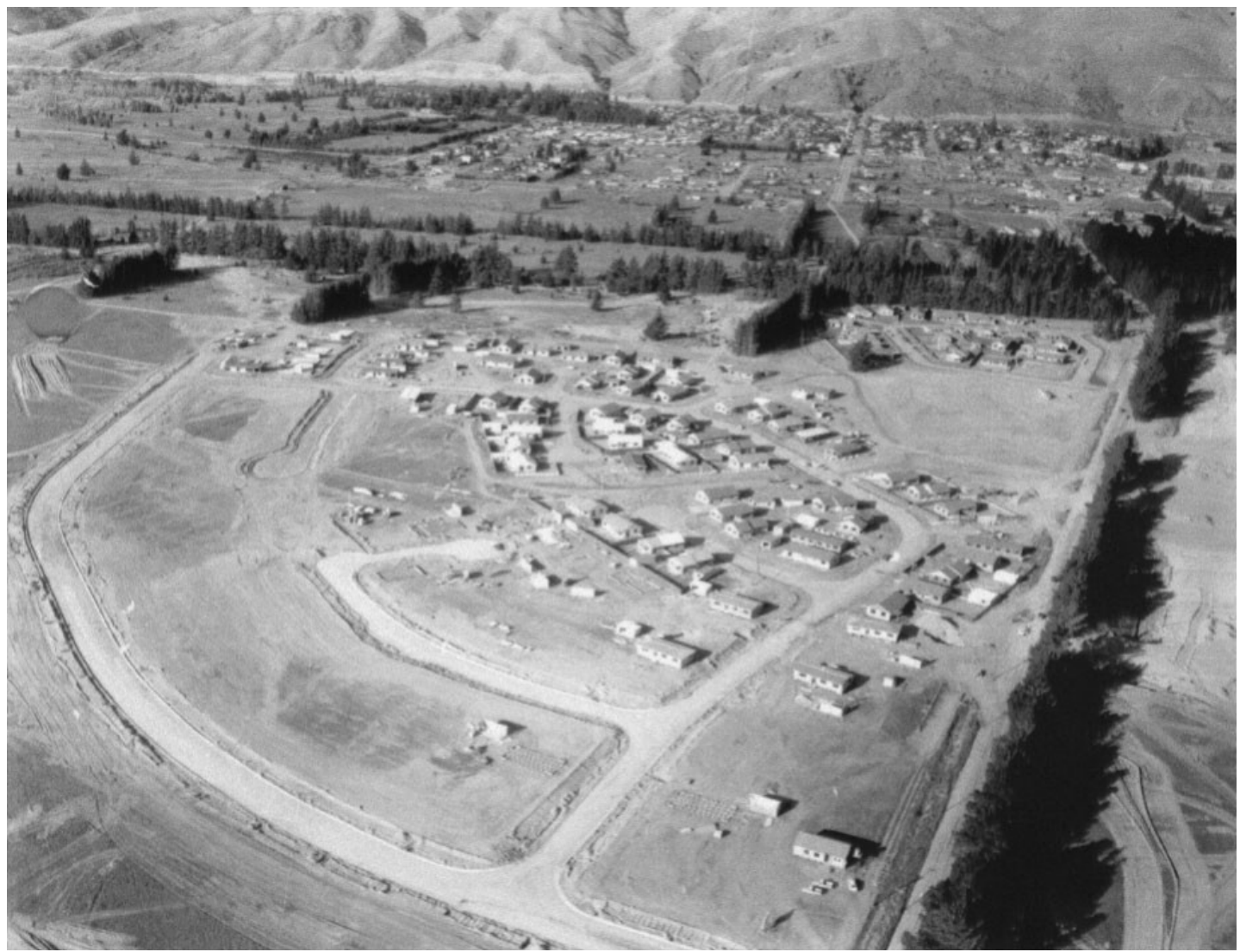

G2: Cromwell workers'subdivision 1978

(Photo courtesy of the Otago Daily Times)

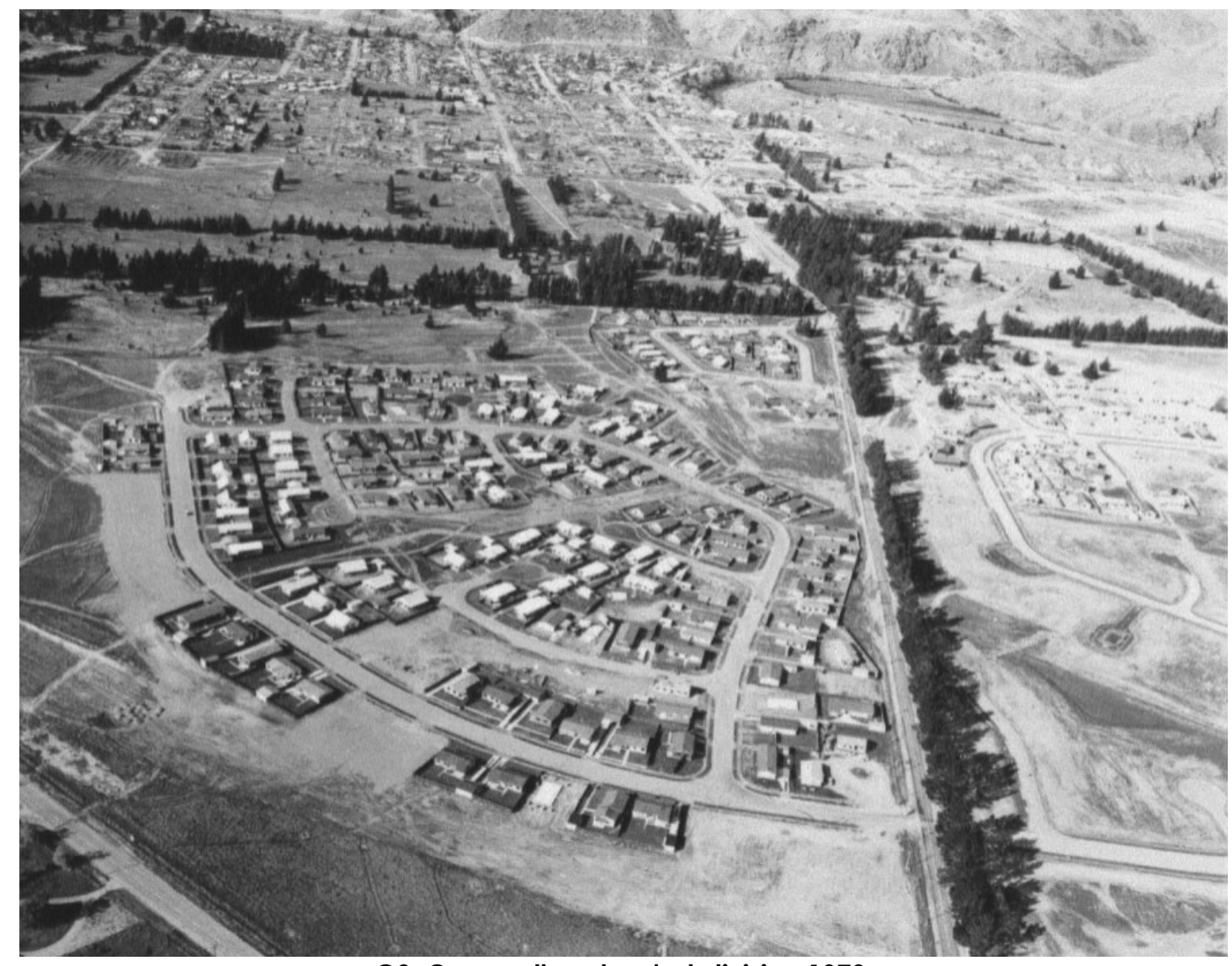

G3: Cromwell workers'subdivision 1979

(Photo courtesy of the Otago Daily Times) 


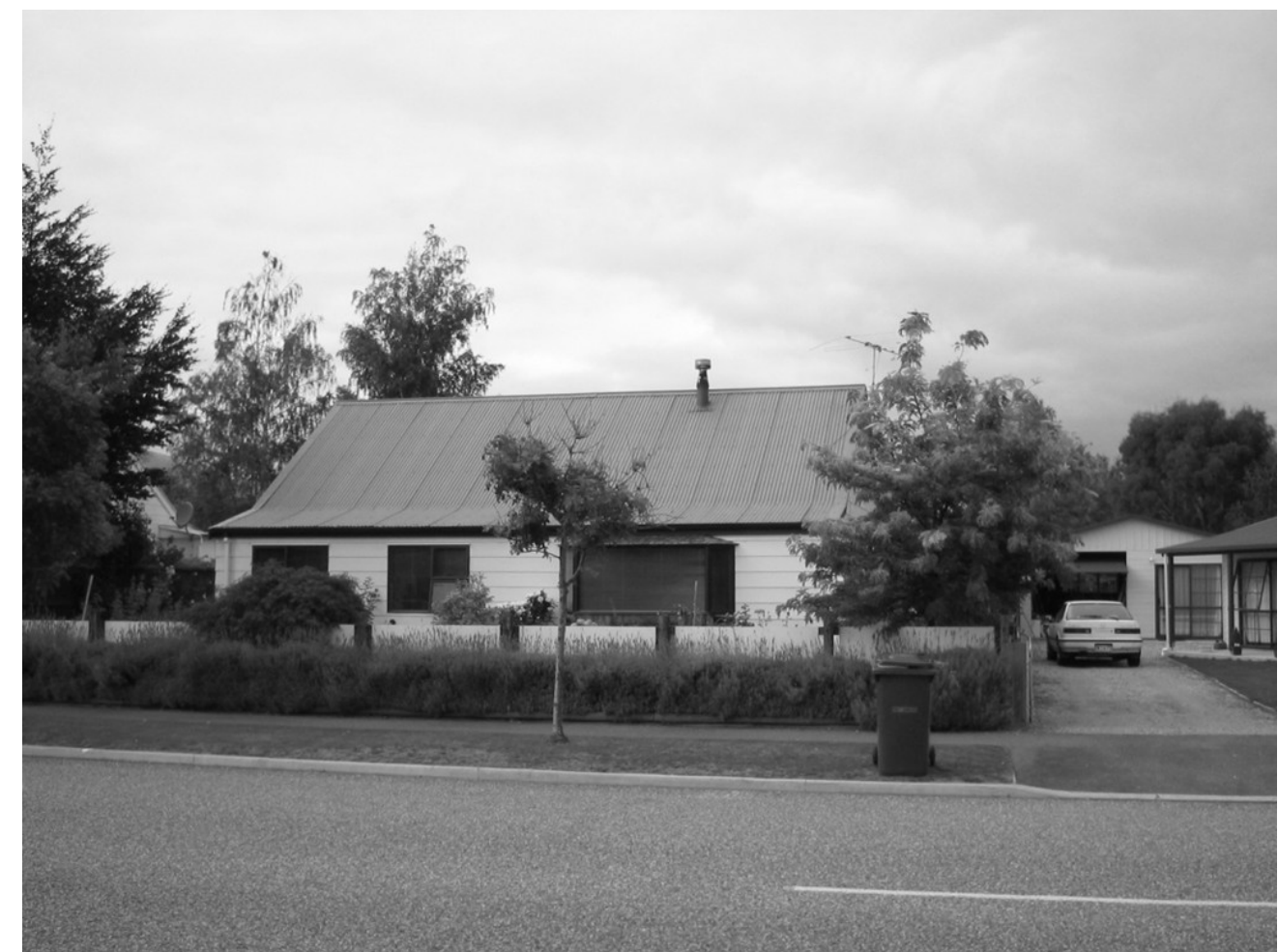

G4: Lightly clad hydro project house at Cromwell, 2007

(Photo by the author)

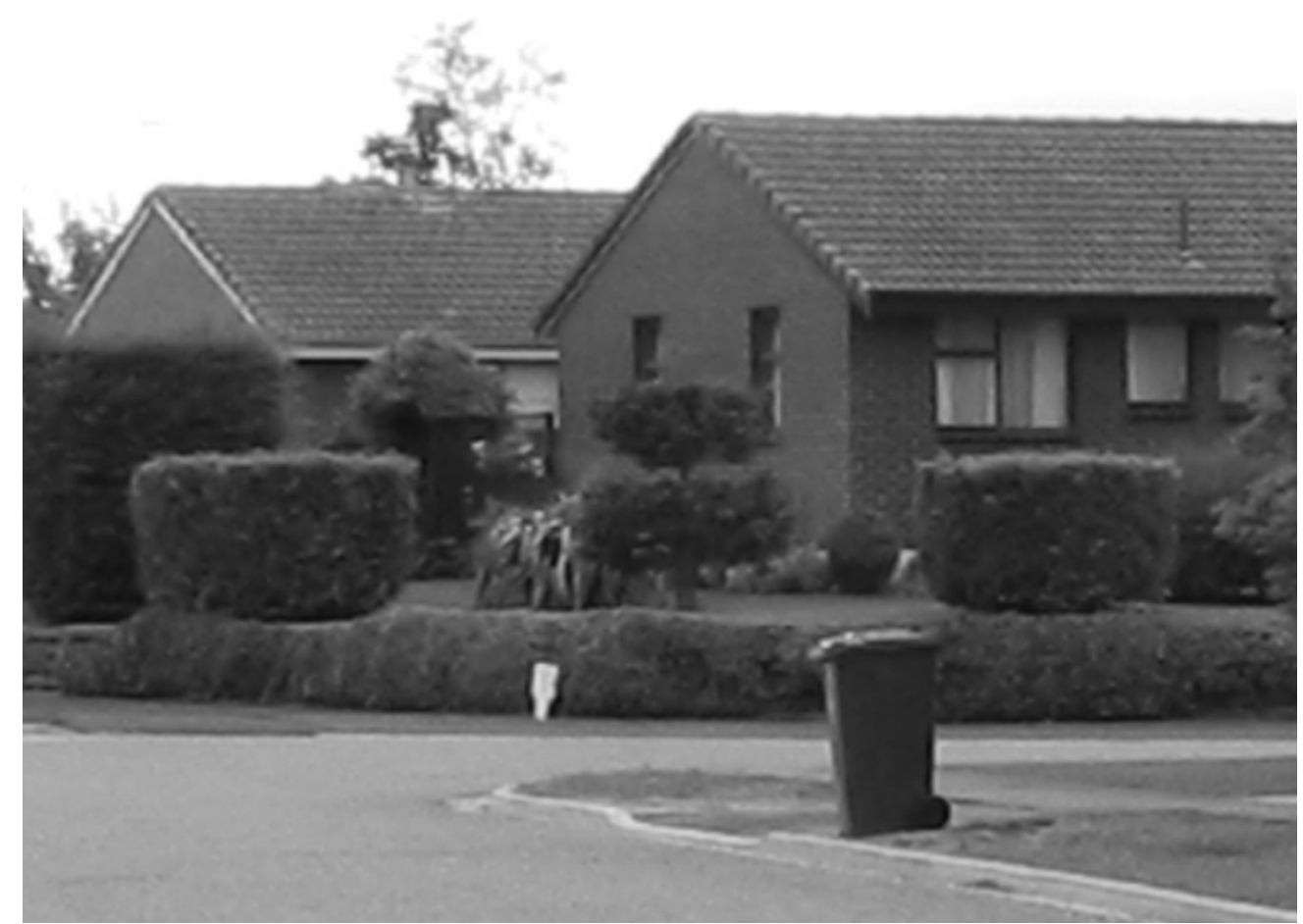

G5: Masonry clad hydro project houses at Cromwell, 2007

(Photo by the author) 


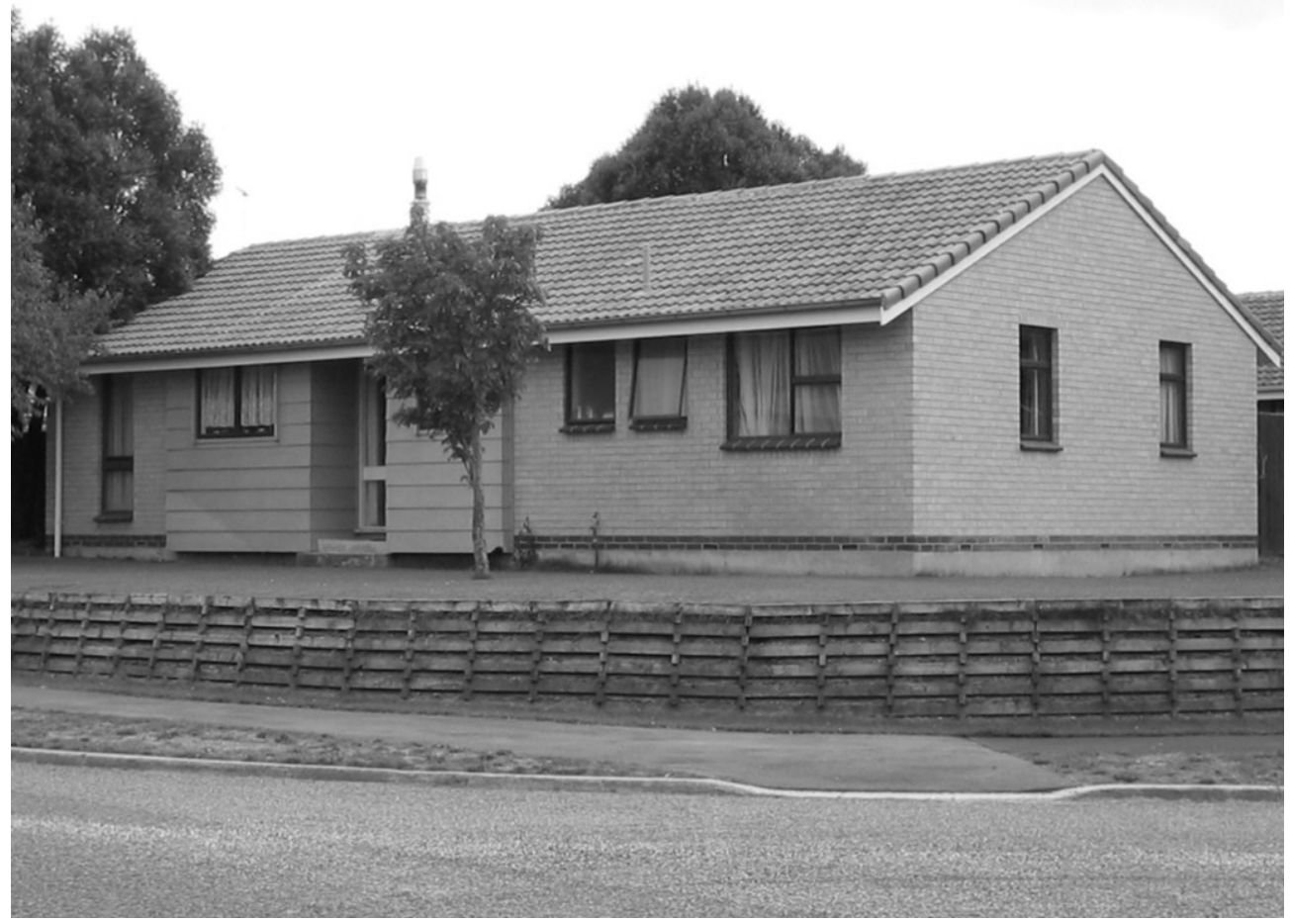

G6: Masonry clad hydro project house at Cromwell, 2007

(Photo by the author)

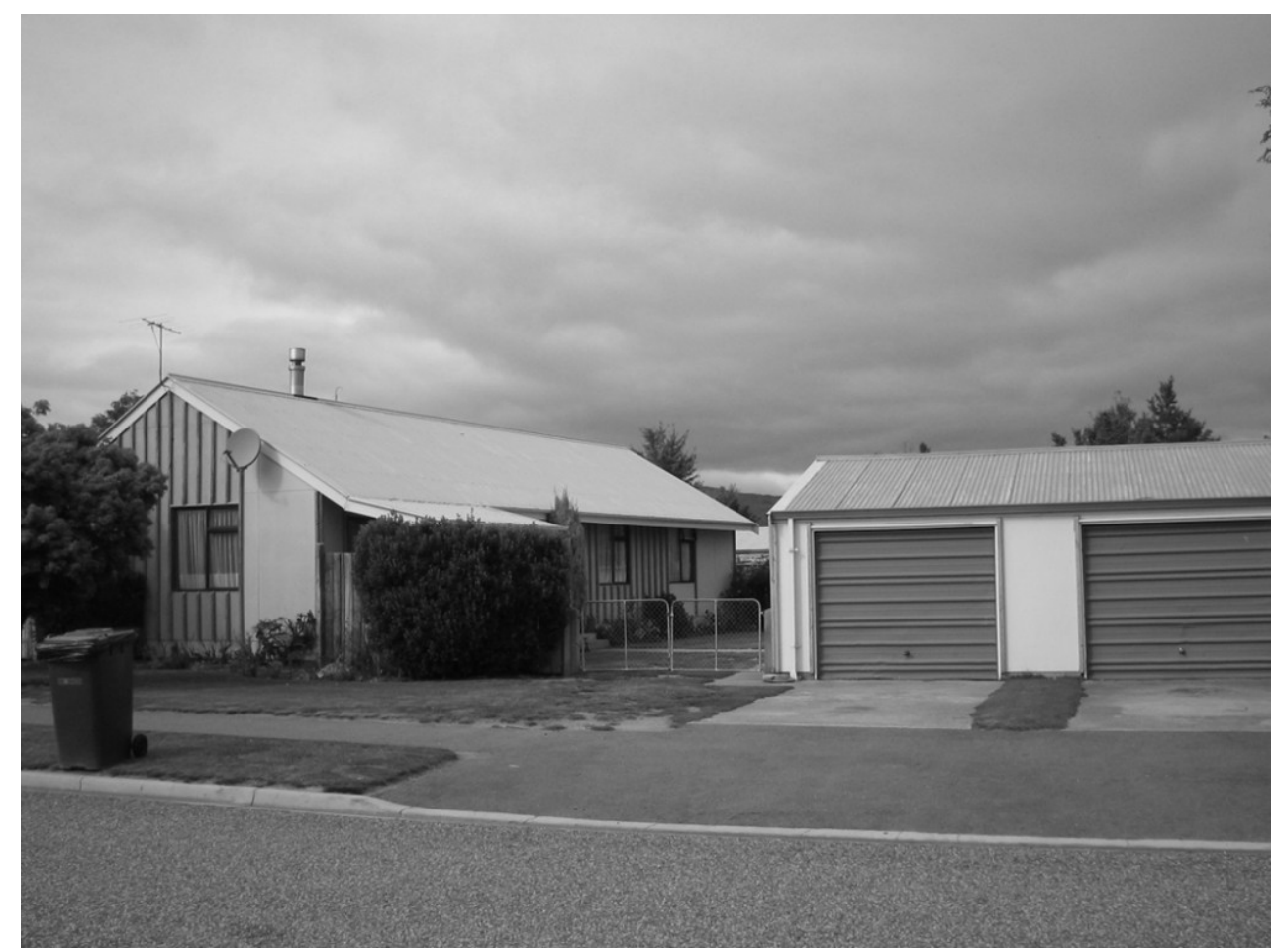

G7: Lightly clad hydro project house with garage at Cromwell, 2007

(Photo by the author) 


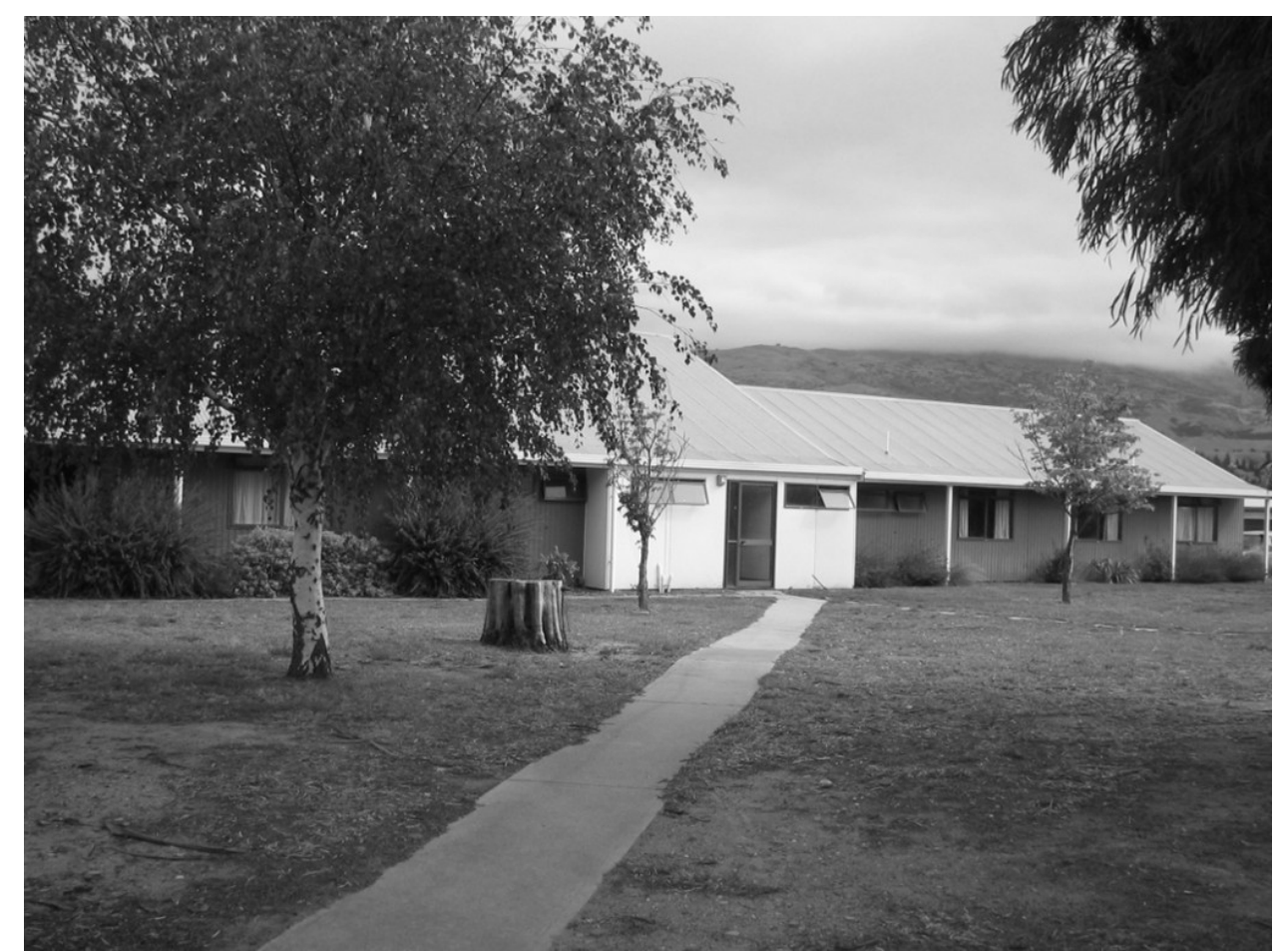

G8: A section of the Zublins' staff hostel, in use at Cromwell Holiday Park, 2007 (Photo by the author) 


\section{H: 2MTT}

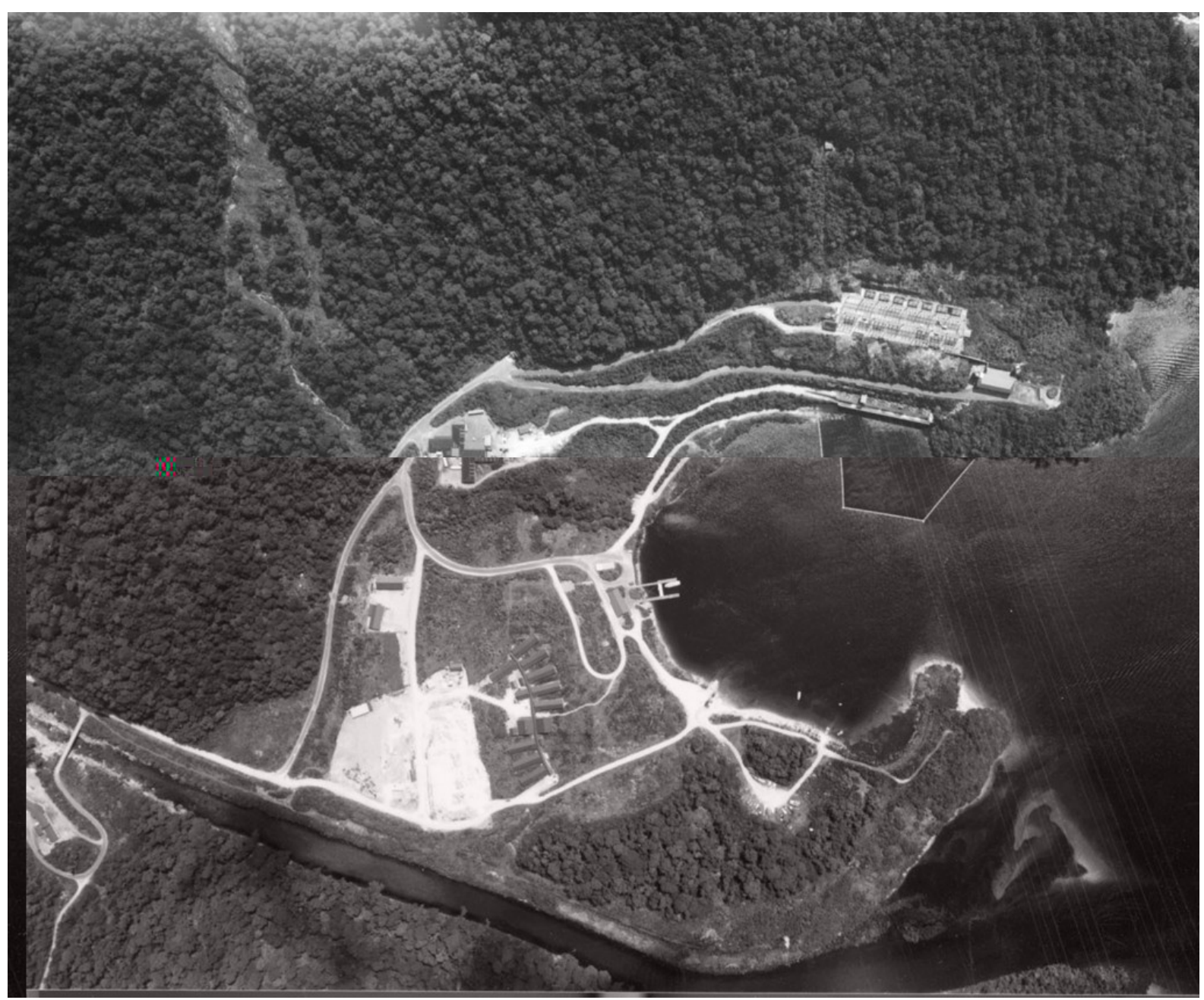

H1: 2MTT West Arm camp site

(Photo courtesy of Southland Regional Council) 


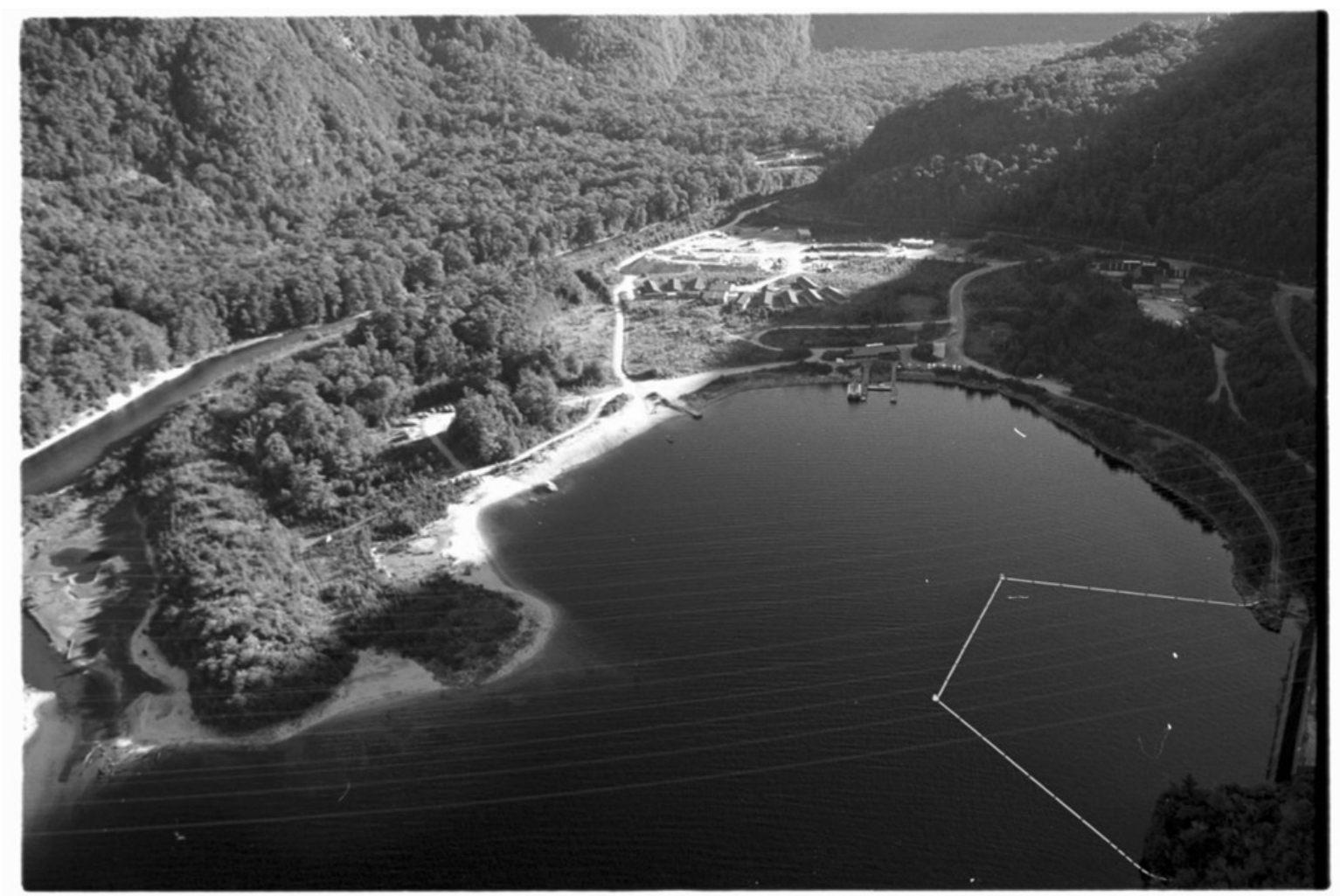

H2: 2MTT West Arm camp site

(Photo courtesy of Meridian Energy)

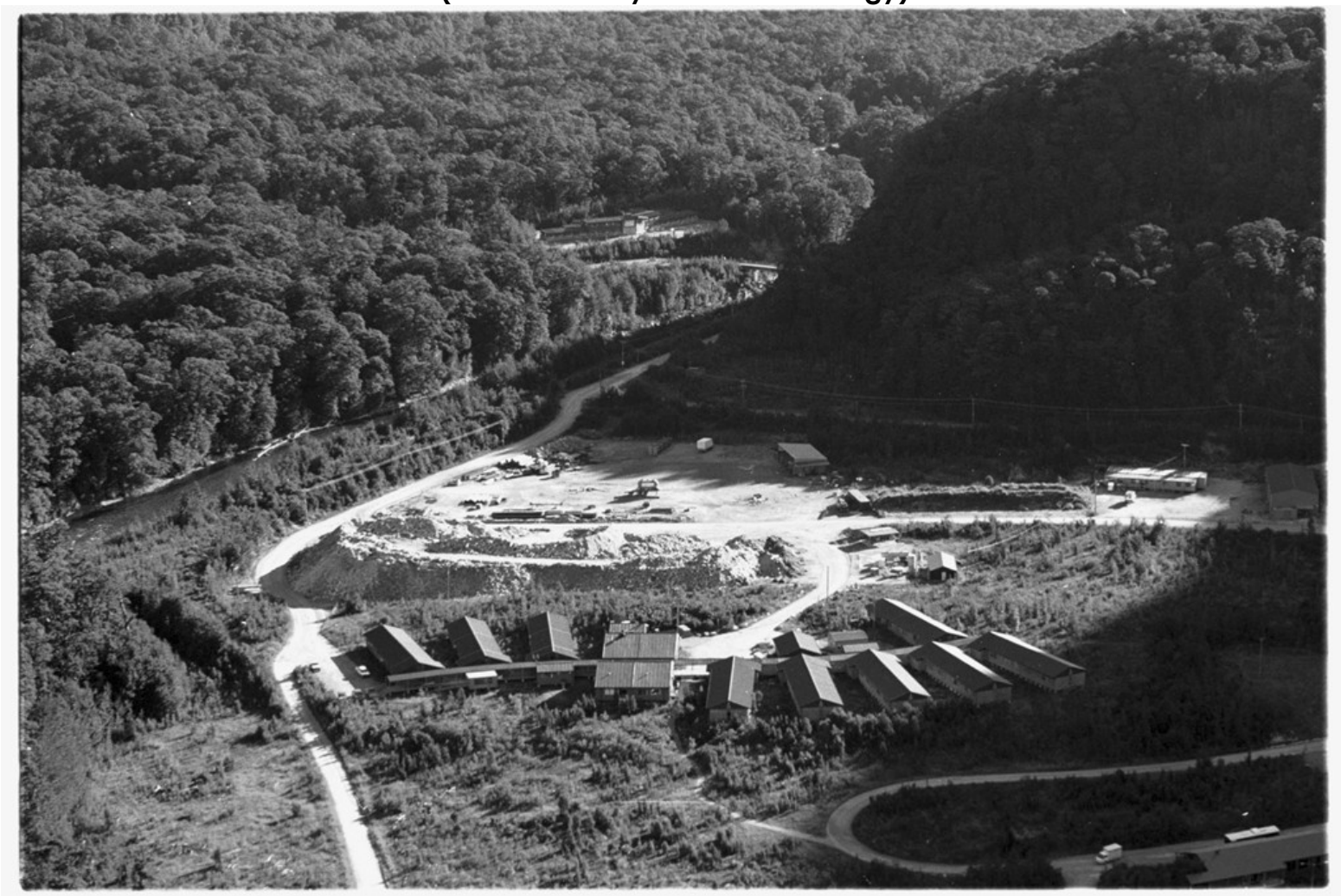

H3: 2MTT West Arm camp site

(Photo courtesy of Meridian Energy) 


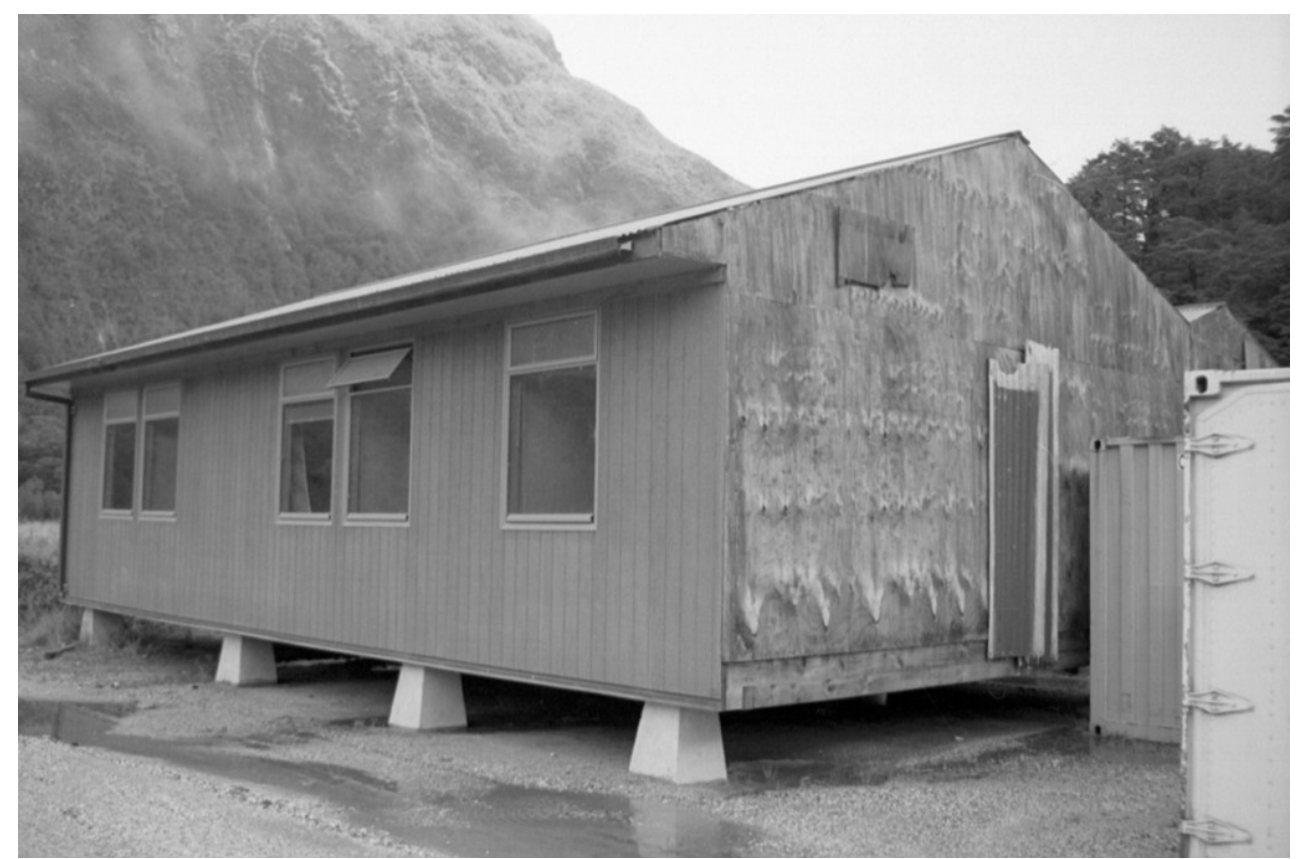

H4: 2 MTT hostel section at West Arm awaiting transportation off site, 2004 (Photo by the author)

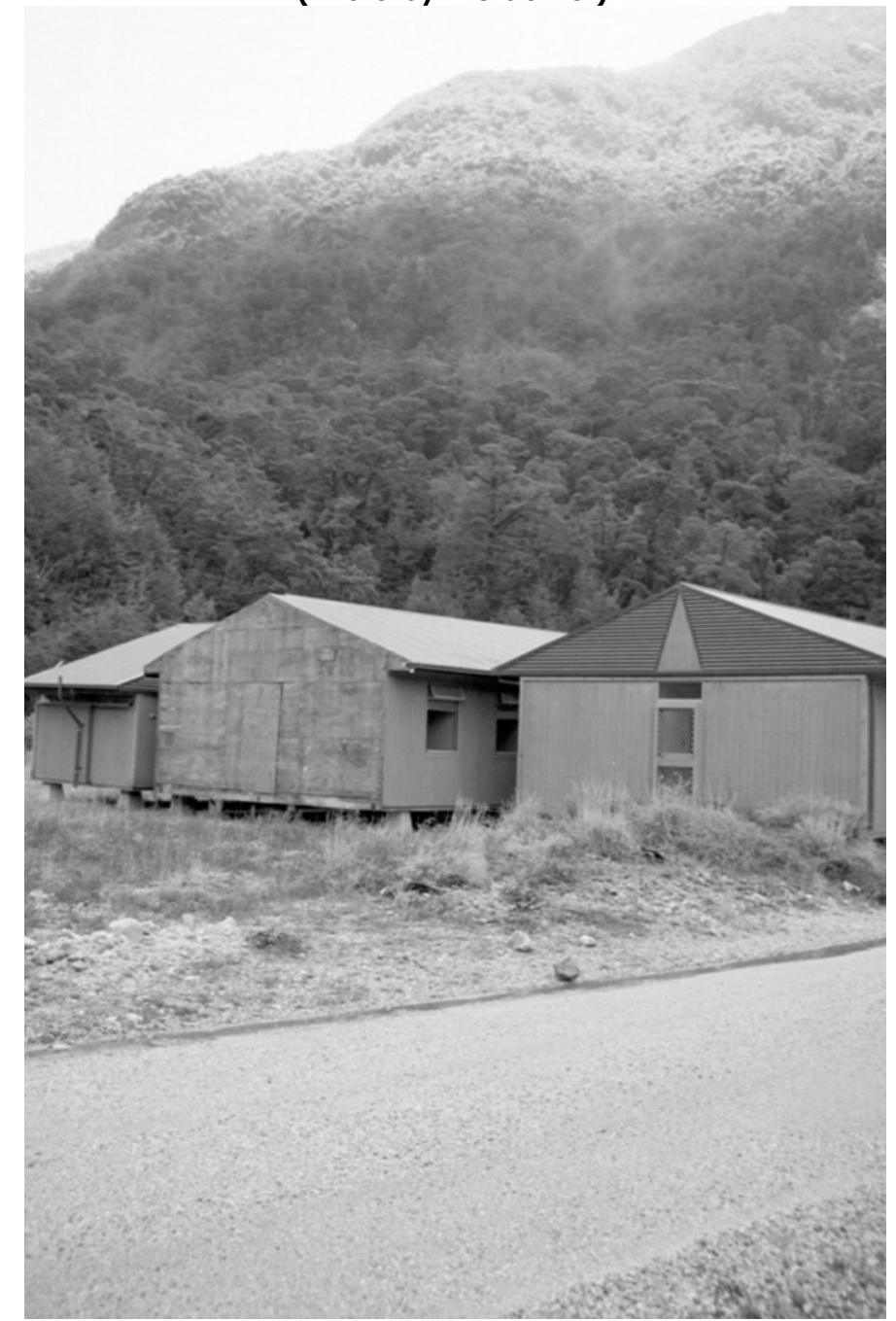

H5: 2 MTT hostel section at West Arm awaiting transportation off site, 2004 (Photo by the author) 


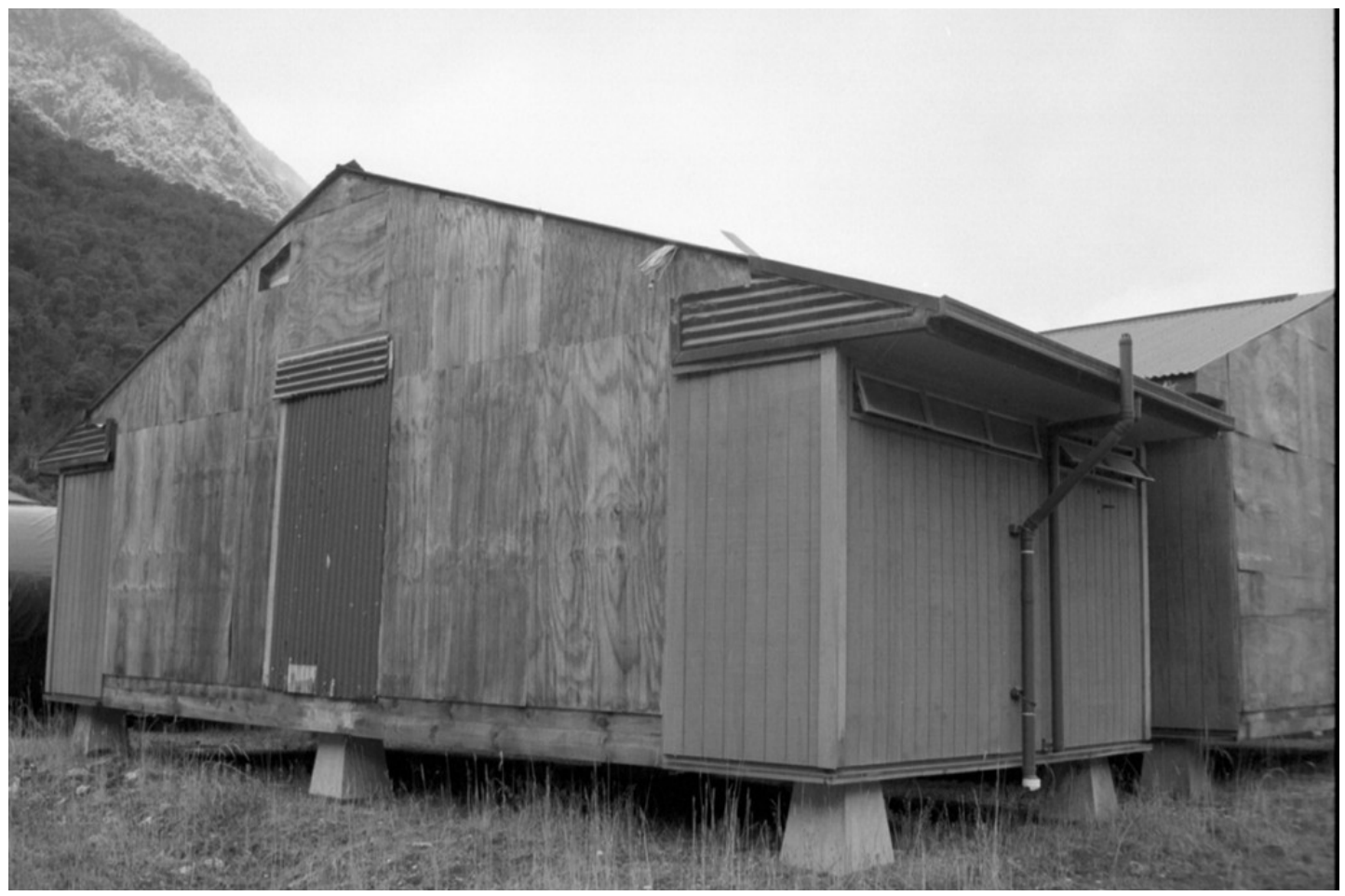

H6: 2 MTT hostel section at West Arm awaiting transportation off site, 2004

(Photo by the author)

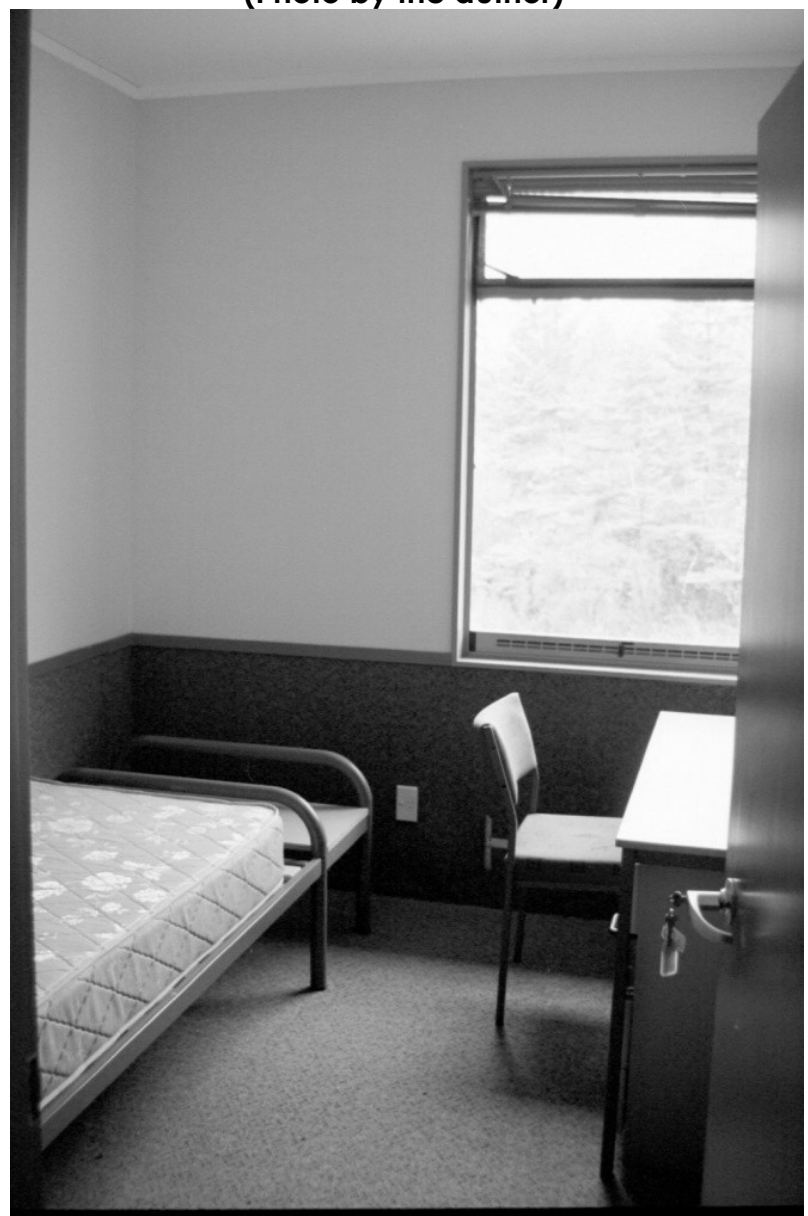

H7: 2MTT hostel bedroom at West Arm awaiting transportation off site, 2004 (Photo by the author) 


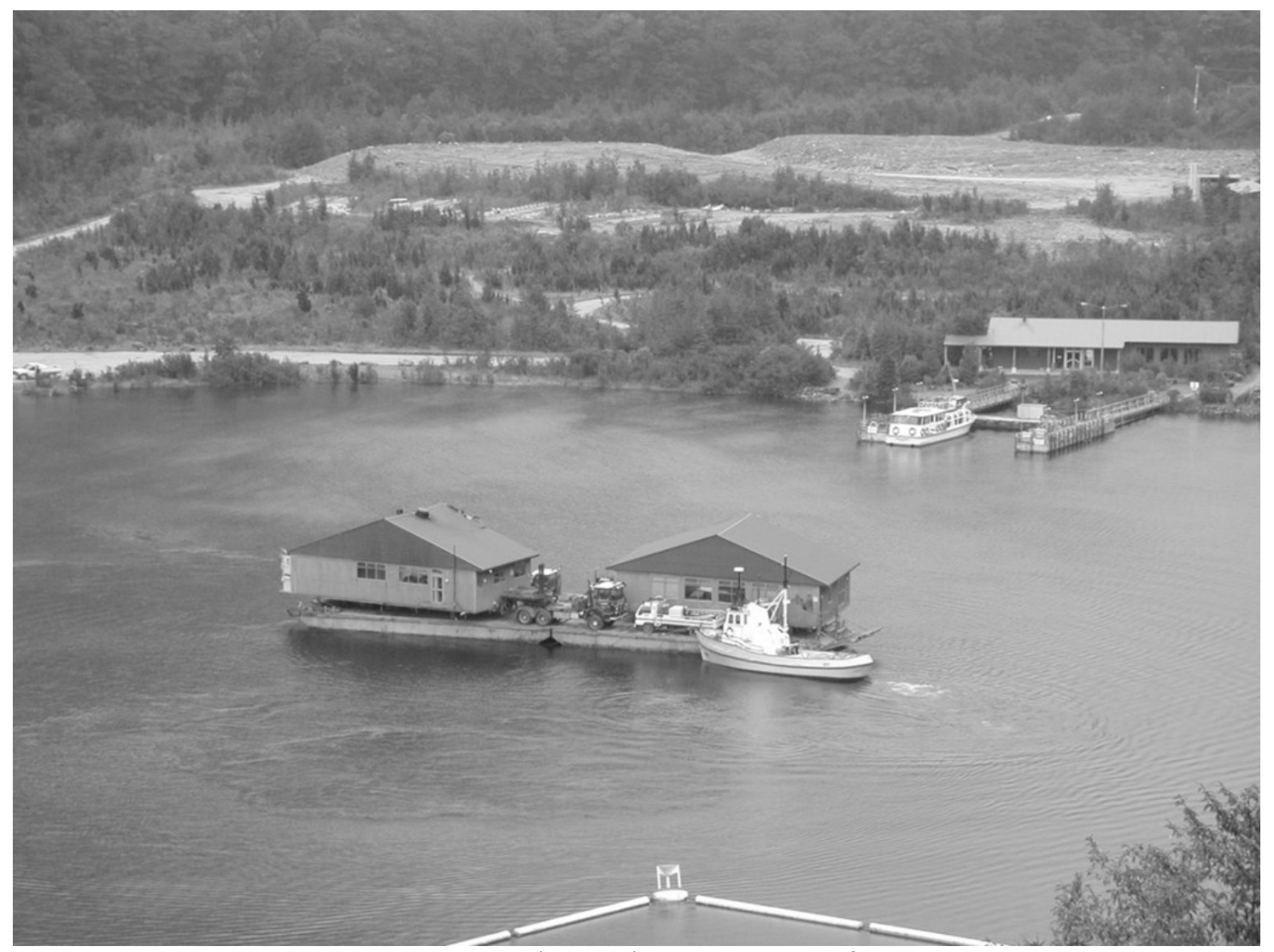

H8: 2MTT hostel sections being barged out of West Arm (Photo courtesy of Meridian Energy)

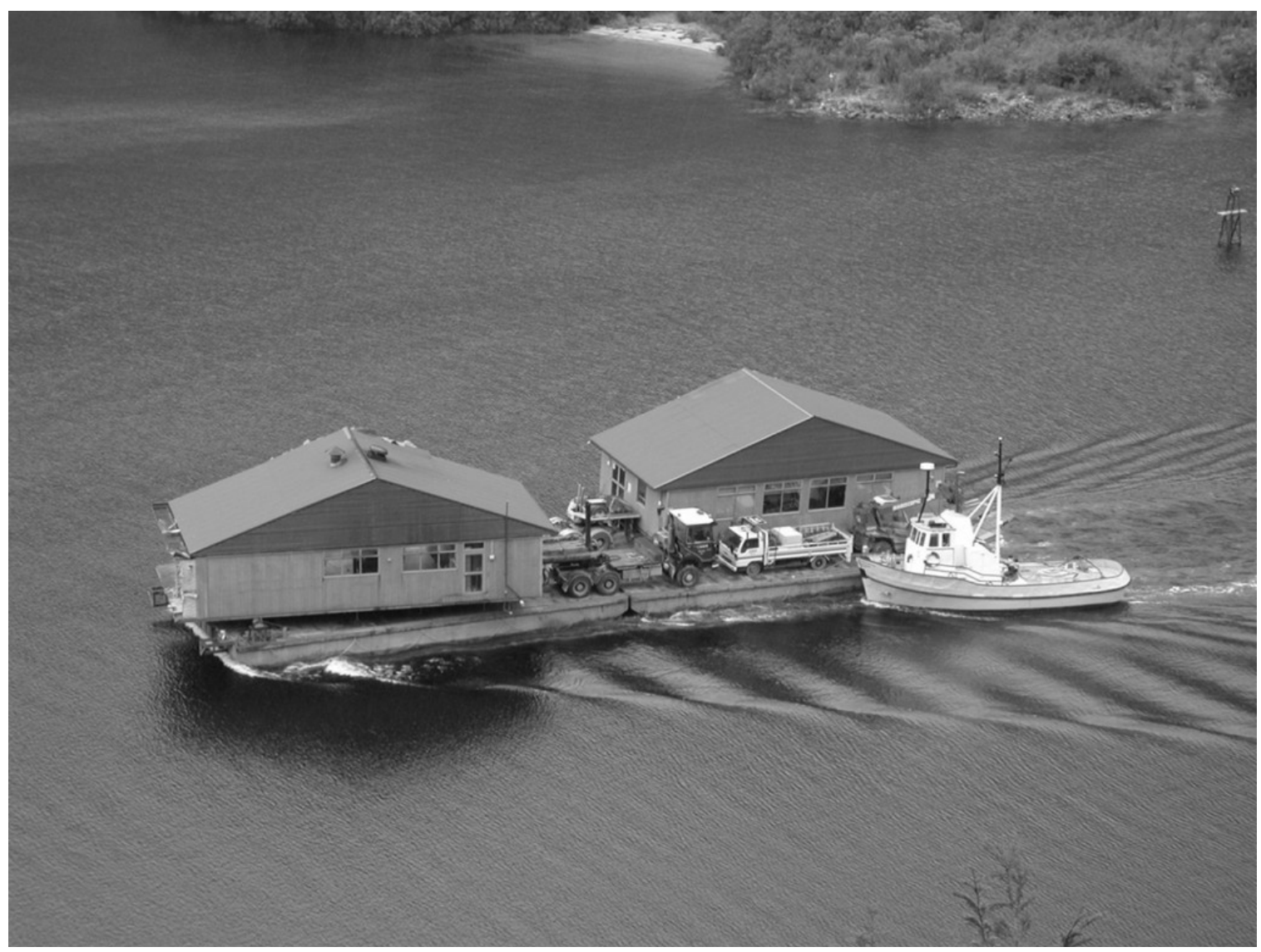

H9: 2MTT hostel sections being barged out of West Arm

(Photo courtesy of Meridian Energy) 


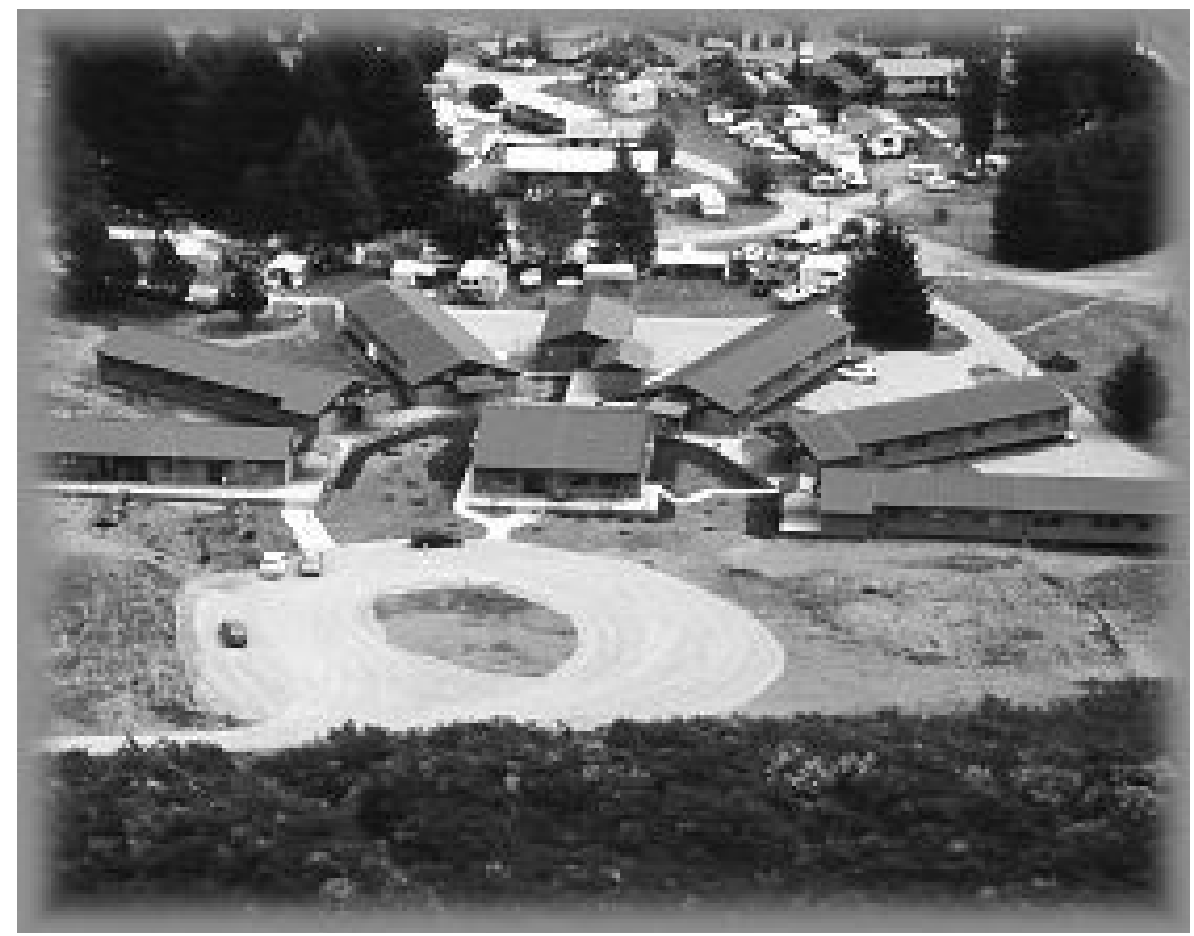

H10: West Arm hostels in place at Te Anau Holiday Park

(Photo courtesy of Te Anau Holiday Park)

The recreation facility building is in the centre

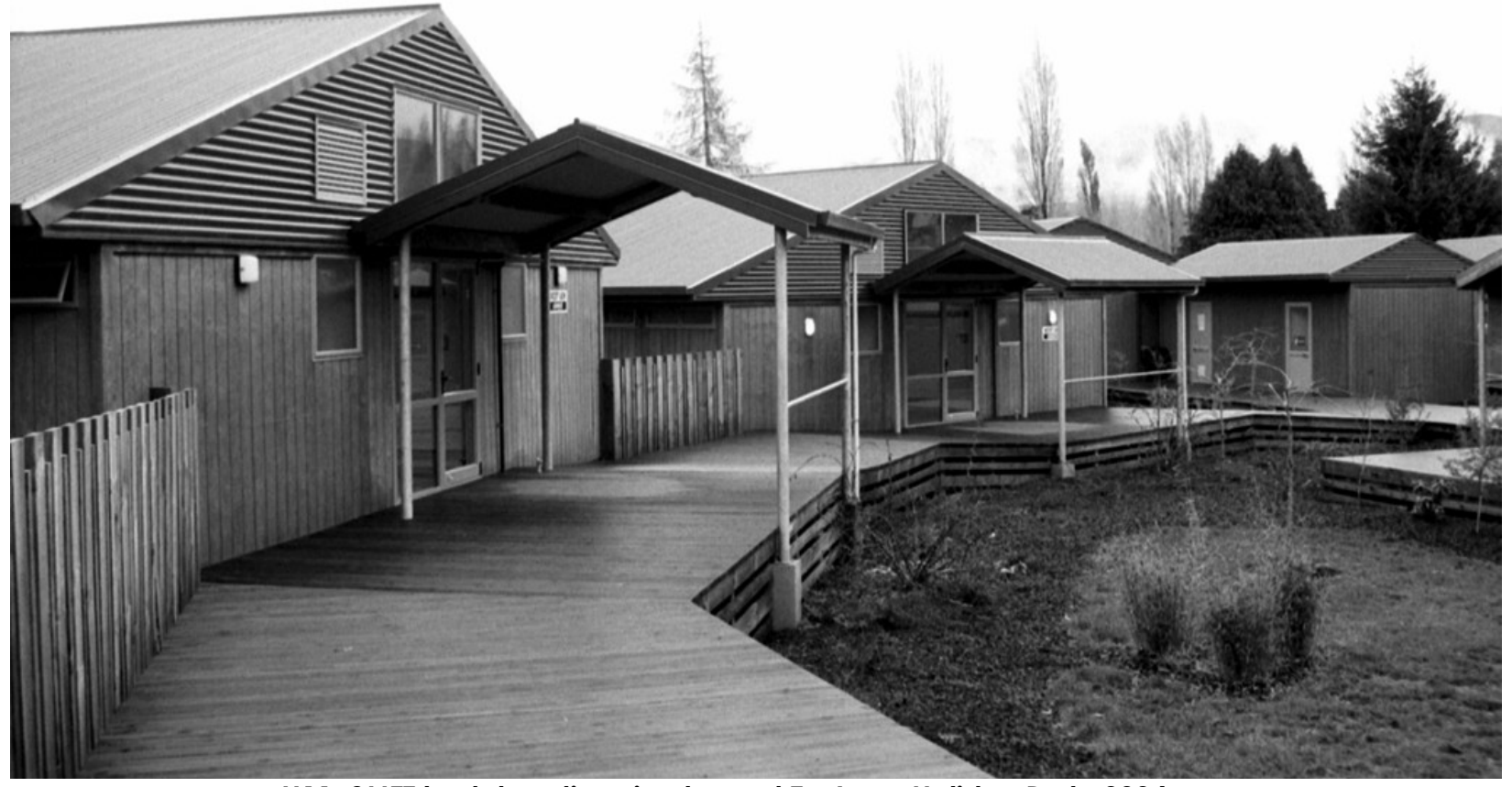

H11: 2MTT hostel sections in place at Te Anau Holiday Park, 2004

(Photo by the author) 


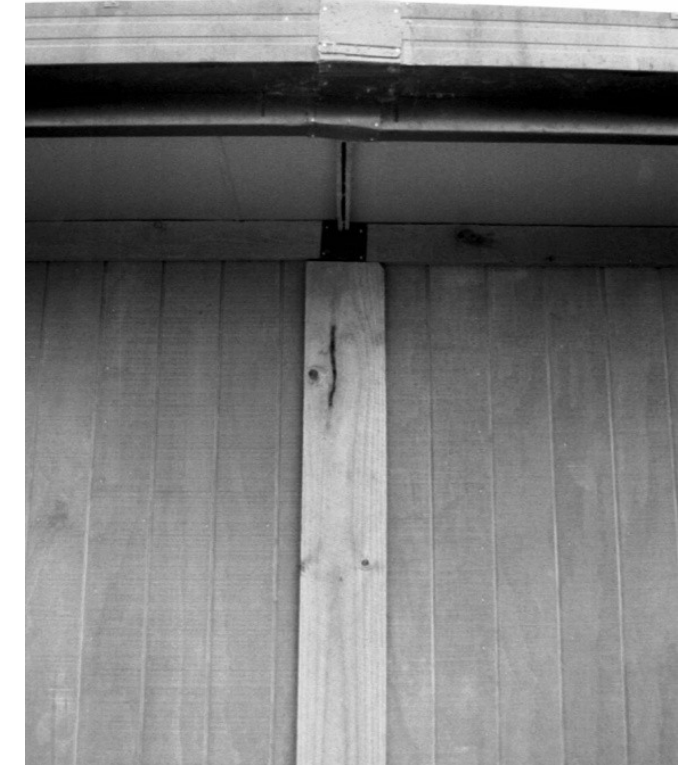

H12: 2 MTT hostel sections joined at Te Anau Holiday Park (Photo by the author)

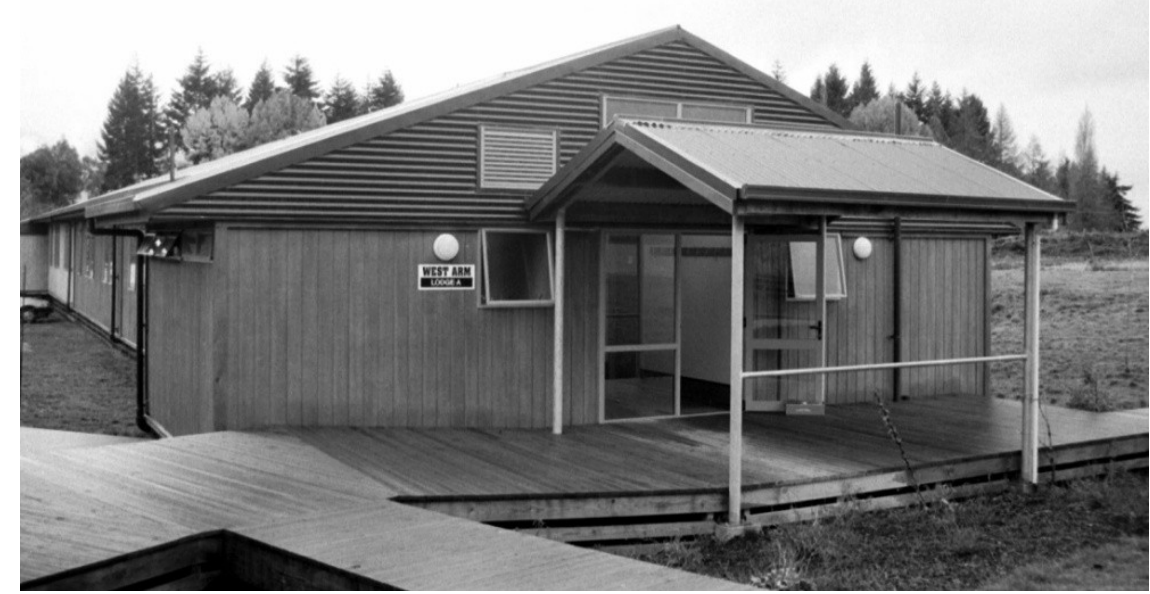

H13: 2MTT hostel sections in place at Te Anau Holiday Park, 2004 (Photo by the author) 


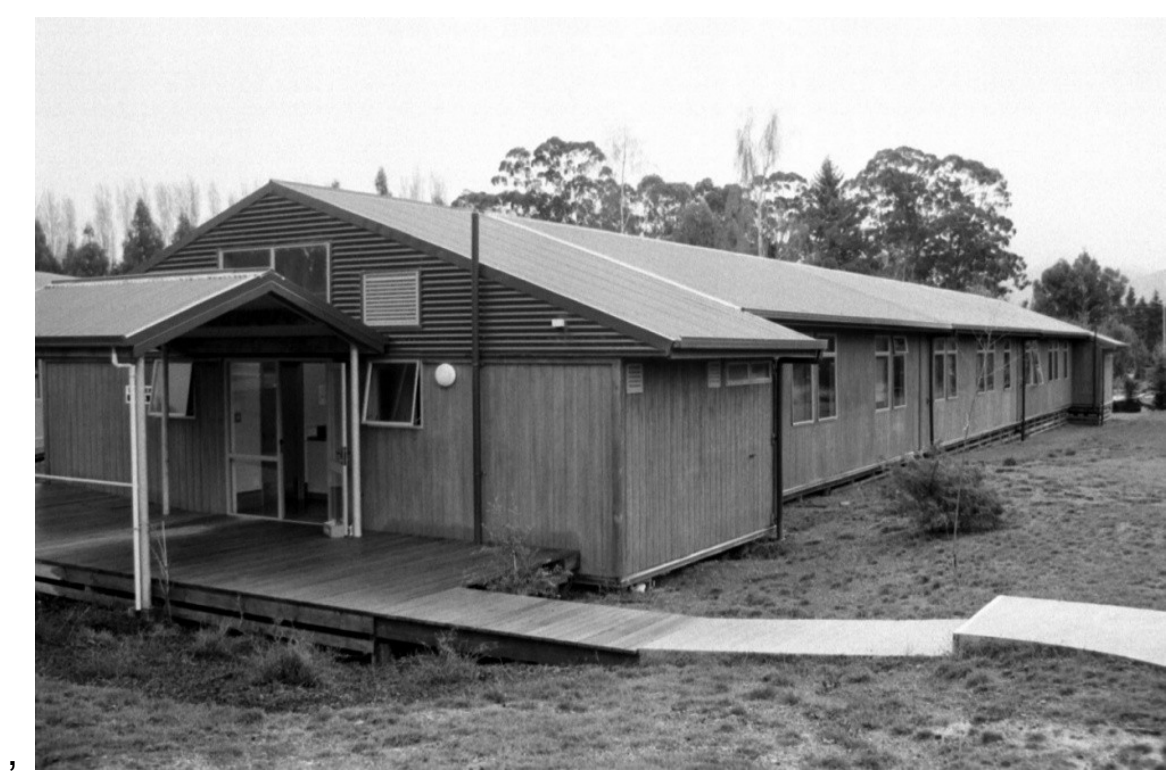

H14: 2MTT hostel sections in place at Te Anau Holiday Park, 2004 (Photo by the author)

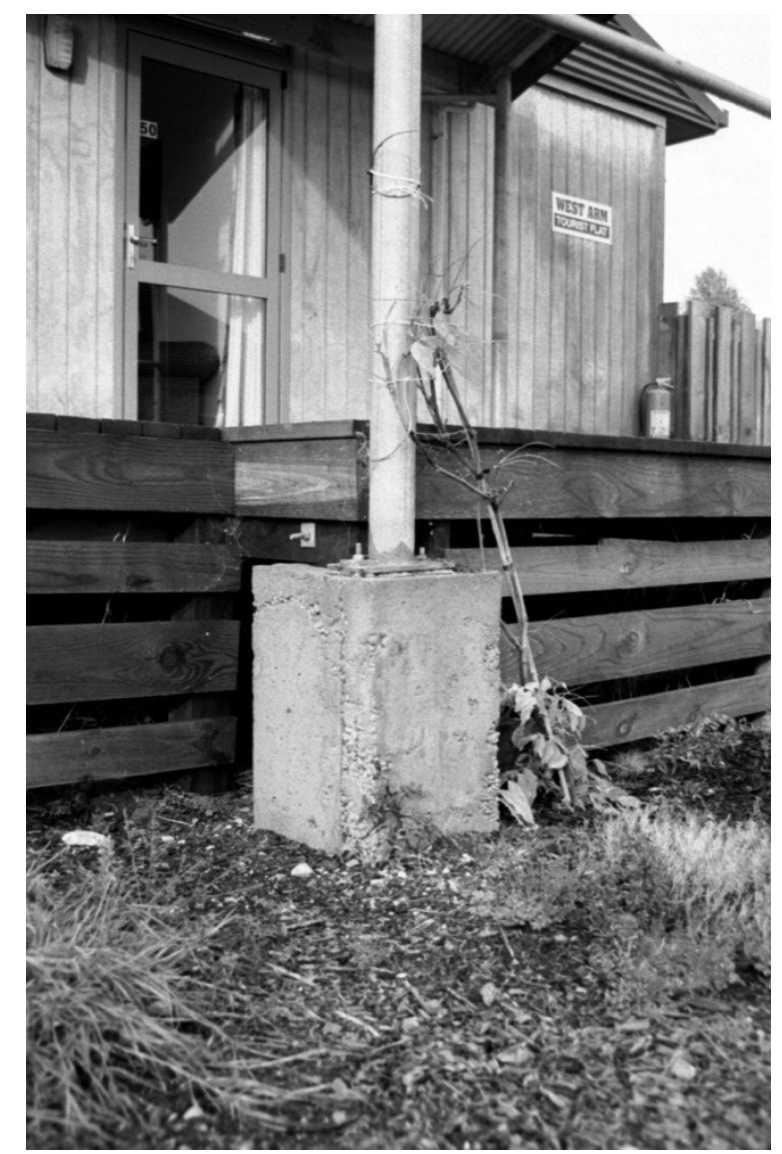

H15: 2MTT hostel sections in place at Te Anau Holiday Park, 2004

(Photo by the author) 


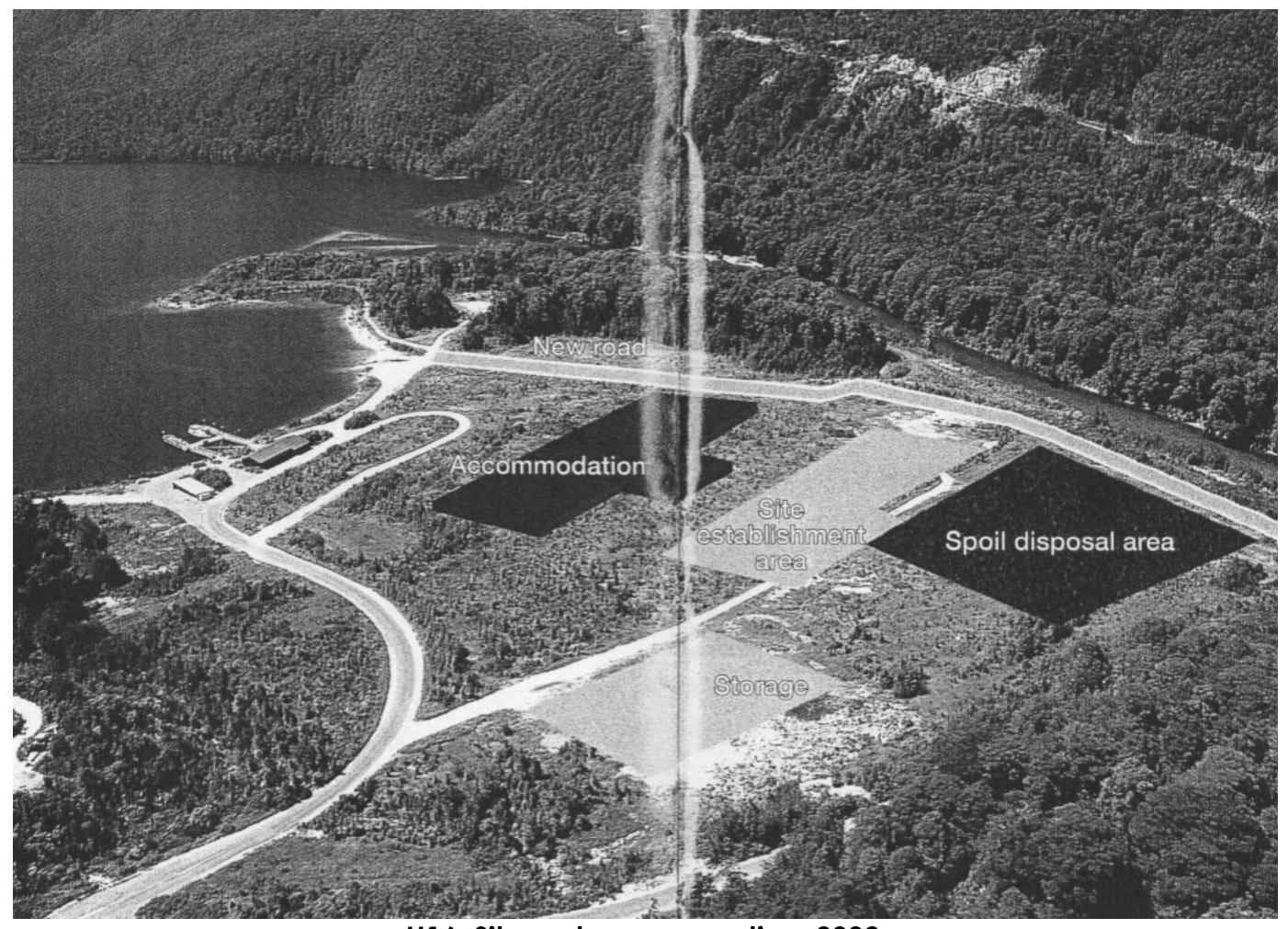

H16: Site under regeneration, 2002

(Photo courtesy of Meridian Energy)

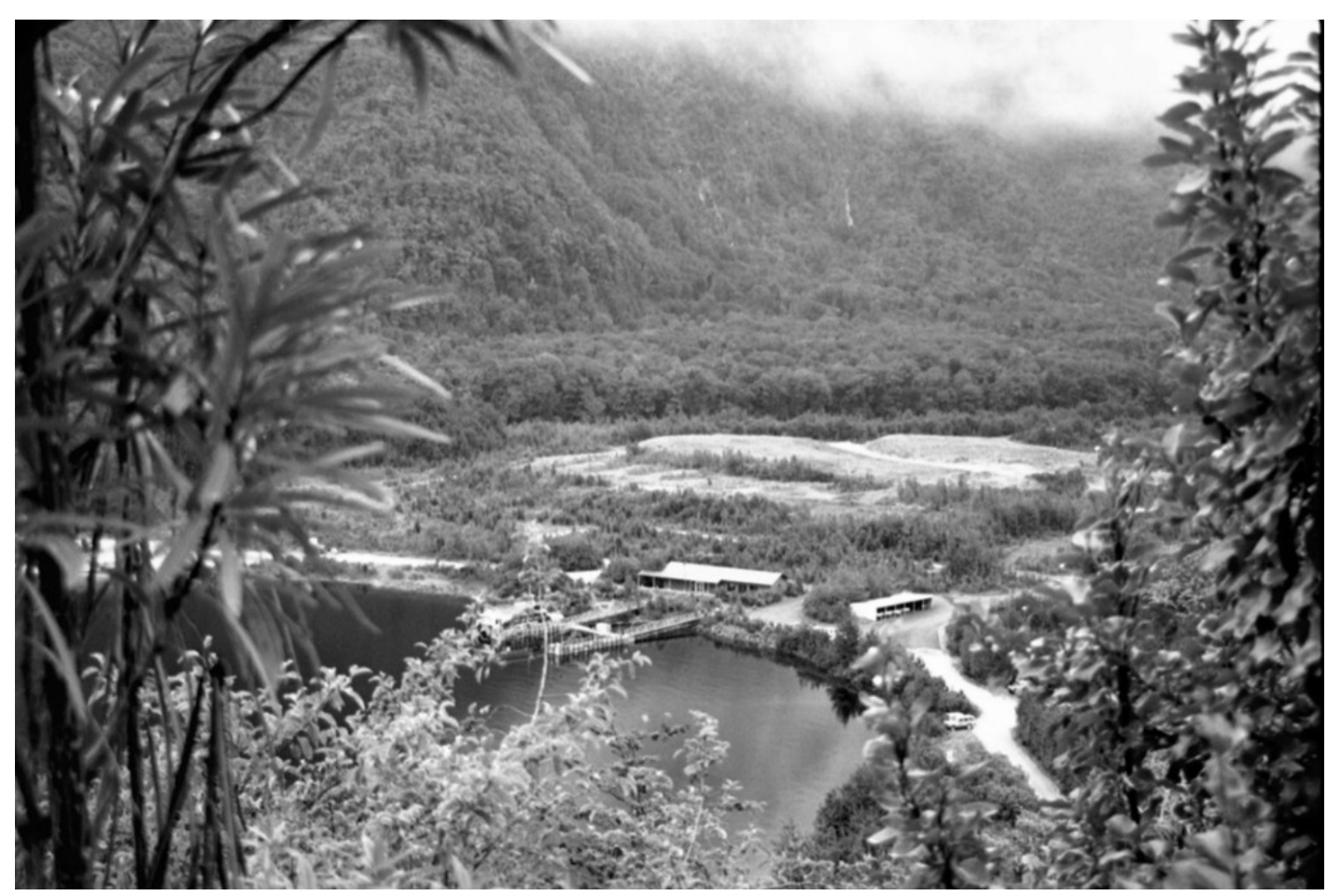

H17: West Arm site regenerating, 2004

(Photo by the author)

The building in the foreground is an information centre for visitors 


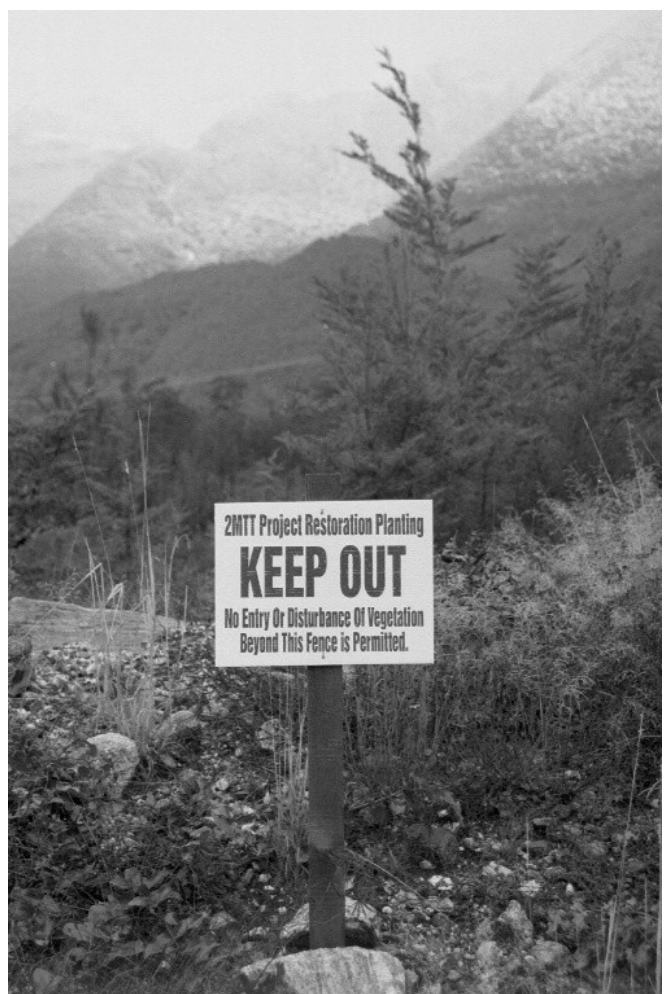

H18: (Photo by the author)

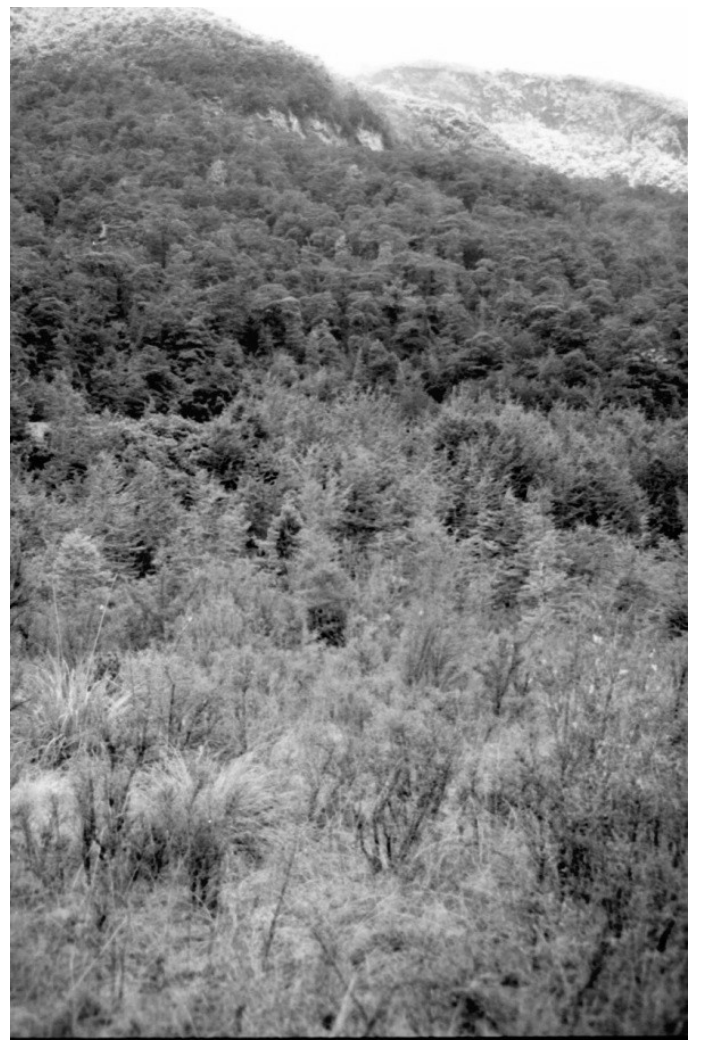

H19: 2MTT hostel site regeneration, 2004 (Photo by the author) 


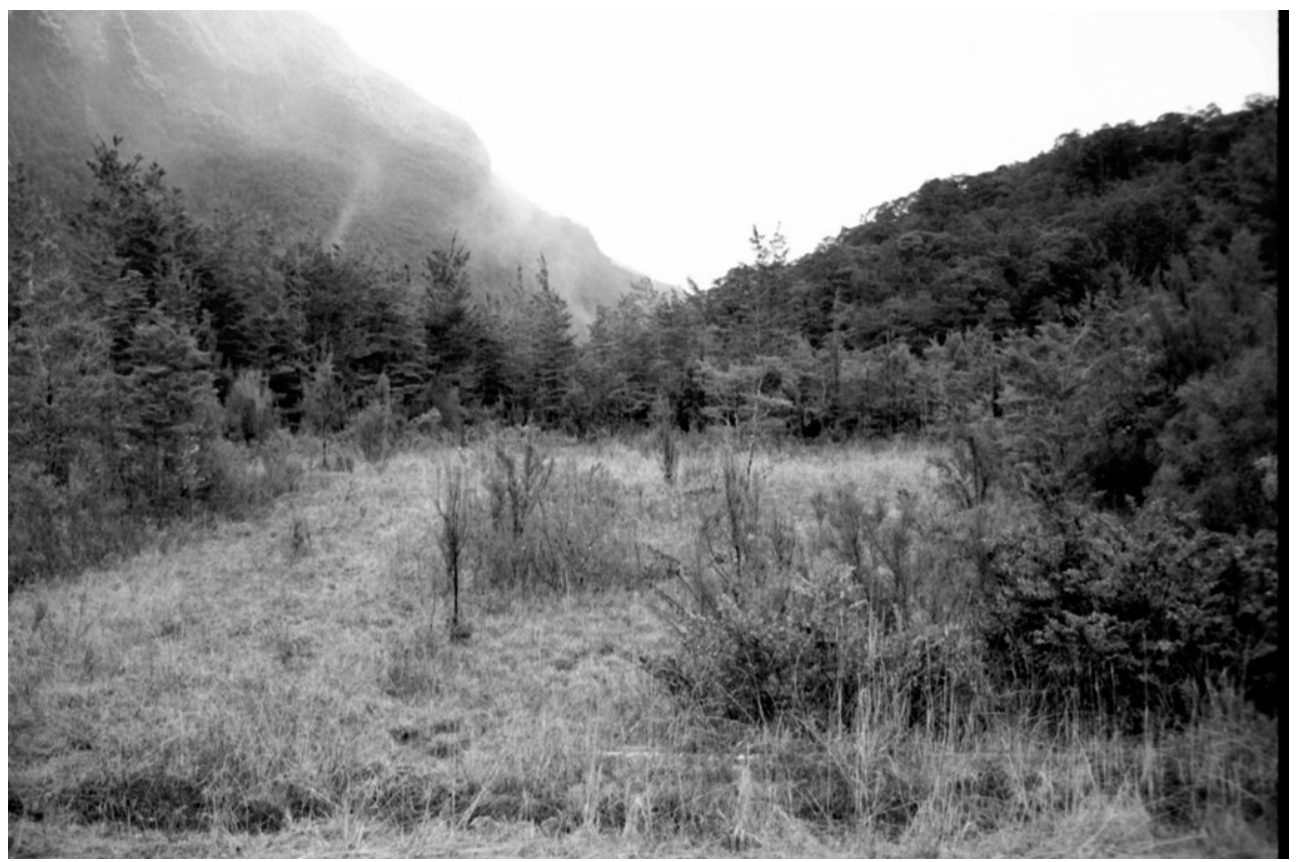

H20: 2MTT hostel site regeneration, 2004

(Photo by the author) 


\title{
I: Western Australia Construction Camp Regulations
}

\author{
As at 13 June, 2004, Version 00 b0 04
}

From www.slp.wa.gov.au, please refer to website for further information. 


\title{
Construction Camp Regulations
}

\author{
CONTENTS
}

Part I - Preliminary

1. Citation 283

4. Onus 283

Part II - General regulations for construction camps

5. Definitions 283

6. Application 284

7. Doors and light in sleeping quarters 285

8. Air space in sleeping quarters 285

9. Ventilation of sleeping quarters 285

10. Space between beds 286

11. Cooking prohibited in sleeping quarters 286

12. Ventilation of kitchen 286

13. Kitchen stoves 287

14. Kitchen protection against insects 287

15. Kitchen floor 287

16. Kitchen facilities 287

17. Kitchen cleansing 288

18. Dining room space 288

19. Ventilation of dining room 289

20. Construction and lighting of dining room 289 
21. Dining room insect protection 289

22. Tables 289

23. Sanitary and ablutionary facilities 290

24. Closets 290

25. Plumbing standards 291

26. Laundry facilities 291

27. Water supply 291

Part III - Caravans used in construction camps

28. Definitions 292

29. Floor areas in residential caravans 293

30. Ceiling heights in residential caravans 294

31. Toilet compartments in relation to food preparation 294

32. Separate sleeping compartments 294

33. Sleeping compartment dimensions 294

34. Fly wire 294

35. Dining caravans 295

36. Kitchen caravans 295

37. Office caravan 295

38. Ablutionary and sanitary caravans 295

39. Materials used in caravan construction 296

40. Internal linings 296

41. Design and construction 297

42. Artificial light 298

43. Residential caravans 298

44. Internal equipment 299

45. Fixed ventilation 300

46. Adjustable ventilation 301

Part IV — Offences and penalties 
47. Offences and penalties 301

Notes

Compilation table 302 
Western Australia

Health Act 1911

\section{Construction Camp Regulations}

\section{Part I - Preliminary}

1. Citation

These regulations may be cited as the Construction Camp Regulations ${ }^{1}$.

[2. $\quad$ Omitted under the Reprints Act 1984 s. 7(4)(d).]

[3. $\quad$ Omitted under the Reprints Act 1984 s. 7(4)(c).]

4. Onus

The onus of complying with these regulations shall unless otherwise provided rest with the occupier of the construction camp.

\section{Part II - General regulations for construction camps}

5. Definitions

In these regulations, unless the context otherwise requires artificial light means light sufficient to illuminate the entire room at 54 lumens per square metre of general illumination, measured on a horizontal plane 915 millimetres above the floor; construction camp means any camp used for a duration of more than 6 months though not necessarily in the one location, for the 
accommodation of a work force of more than 25 persons in conjunction with -

(a) the construction of a railway line or siding;

(b) the construction, structural alteration or demolition of -

(i) a building;

(ii) a dock, wharf, jetty, pier, breakwater, tunnel, dam, viaduct, reservoir, pipeline, gasholder; and

(iii) waterworks or sewerage works;

(c) the preparation of an area for mining operations; and

(d) any other work that requires a temporary resident work force,

but does not include -

(e) camps used for defence purposes; and

(f) wayside camps of drovers or teamsters;

dining room means a dining room in any construction camp to which this Part applies;

effective air conditioning means the distribution of filtered air into an enclosed space at controlled temperatures and humidity and effectively air conditioned has a corresponding meaning;

kitchen means a kitchen in any construction camp to which this Part applies;

occupier means a person having the charge, management or control of premises, and where 2 or more persons share or jointly have the charge, management or control of premises, each of those persons;

sleeping quarters means sleeping quarters in any construction camp to which this Part applies.

[Regulation 5 amended in Gazette 18 Nov 1970 p. 3586; 3 May 1974 p. 1428.$]$

\section{Application}

This Part does not apply to caravans in construction camps. 
7. Doors and light in sleeping quarters

Every sleeping quarters shall -

(a) have at least one door of at least 760 millimetres in width and 1.98 metres in height; and

(b) be provided with artificial light.

[Regulation 7 amended in Gazette 3 May 1974 p. 1428.]

8. Air space in sleeping quarters

(1) Every sleeping quarters shall contain not less than 11 cubic metres of air space calculated for each person who sleeps in the quarters, except where the sleeping quarters are transportable units which shall contain not less than 9 cubic metres of air space for each such person.

(2) Where transportable units used as sleeping quarters in any area north of the 26th parallel of latitude or in any other area specified by the Minister by notice published in the Gazette, contain less than 11 cubic metres of air space for each person who sleeps in the quarters, effective air conditioning shall be installed in those sleeping quarters.

[Regulation 8 inserted in Gazette 18 Nov 1970 p. 3586; amended in Gazette 3 May 1974 p. 1428.]

9. Ventilation of sleeping quarters

Every sleeping quarters shall be ventilated -

(a) by the provision of a window or windows, which when opened, either singly or in the aggregate, provide an open space -

(i) that has a minimum area of 0.5 square metre for every 10 square metres of floor area;

(ii) the highest part of which is within 460 millimetres of the ceiling line; and

(iii) that provides direct uncontrolled ventilation to the external air; 
or

(b) by permanent ventilation consisting of 0.015 square metre of uncontrolled ventilation for each 10 square metres of floor area; or

(c) by a system of mechanical ventilation giving not less than 6 changes of air per hour.

[Regulation 9 amended in Gazette 3 May 1974 p. 1428.]

10. Space between beds

Every sleeping quarters shall have a space of not less than 810 millimetres between each bed.

[Regulation 10 amended in Gazette 18 Nov 1970 p. 3586; 3 May 1974 p. 1428.]

11. Cooking prohibited in sleeping quarters

No person shall be permitted to prepare or partake of a meal in any sleeping quarters, except when a person is confined to those quarters by ill-health.

\section{Ventilation of kitchen}

(1) Every kitchen shall be ventilated by one of the following methods -

(a) by natural ventilation consisting of -

(i) one or more windows placed in an external wall, so constructed that portion of the windows equal to at least one-twentieth of the floor area of the room can be opened and portion of each such window extends to at least 1.98 metres above the floor level; and

(ii) by registers, vents, cowls or ducts, fixed in or near the ceiling boxed in and having a baffle of 50 millimetres clear above the boxing and extending 75 millimetres beyond it on all sides, so as to provide an effective airway of not less than 4000 square millimetres for each one square metre of floor area; 
or

(b) by a system of mechanical ventilation giving not less than 15 complete changes of air per hour.

(2) For the purposes of subregulation (1)(a)(i), where a kitchen is fitted with a door -

(a) the upper half of which moves independently of the lower half;

(b) which is fitted in an external wall; and

(c) which extends to at least 1.98 metres above floor level, the area of the upper half of that door may be regarded as the opening portion of a window.

[Regulation 12 amended in Gazette 3 May 1974 p. 1428-9; 12 Jul 1974 p. 2597.$]$

\section{Kitchen stoves}

Every stove in a kitchen shall have a hood connected to a ventilation shaft sufficient to carry away all steam and cooking odours.

\section{Kitchen protection against insects}

(1) The windows, doorways and other openings in every kitchen shall be screened with a fine mesh to exclude the ingress of flies and other insects.

(2) Food in any kitchen not being prepared and not in the refrigerator shall be kept in fly proof cupboards.

15. Kitchen floor

Every kitchen floor shall be of an impervious material.

16. Kitchen facilities

Every kitchen shall be equipped with -

(a) a stainless steel sink for dishwashing; 
(b) a stainless steel wash trough for washing pots and larger kitchen utensils;

(c) a handbasin supplied with hot and cold water, soap, nailbrush and disposable paper towels;

(d) an adequate supply of hot water available at all times;

(e) food preparation tables with a smooth impervious washable surface of a material other than lino;

(f) adequate refrigerated storage for keeping perishable foods;

(g) a sufficient number of rubbish receptacles with a smooth impervious surface and tight fitting lid, for the reception of food scraps; and

(h) artificial light.

\section{Kitchen cleansing}

(1) Every kitchen and all its facilities shall be maintained in a clean and efficient condition.

(2) To enable cleansing to be carried out in the kitchen -

(a) stoves, not sealed against a wall, shall be positioned at least 75 millimetres clear of the wall;

(b) benches and fixtures not built into the floor, shall be at least 380 millimetres clear of the floor; and

(c) all cupboards and other fixtures and all walls and ceilings shall have smooth impervious washable surfaces.

[Regulation 17 amended in Gazette 3 May 1974 p. 1429.]

18. Dining room space

Every dining room shall contain at least one square metre of space for each person it accommodates at any one time.

[Regulation 18 amended in Gazette 18 Nov 1970 p. 3586; 3 May 1974 p. 1429.] 
19. Ventilation of dining room

Every dining room shall be ventilated -

(a) by controllable ventilation and by permanent ventilation consisting of 0.015 square metre of uncontrolled ventilation for every 10 square metres of area;

(b) by a system of mechanical ventilation giving not less than 8 complete changes of air per hour; or

(c) by effective air conditioning.

[Regulation 19 amended in Gazette 18 Nov 1970 p. 3586; 3 May 1974 p. 1429.]

20. Construction and lighting of dining room

Every dining room -

(a) shall be lined and ceiled;

(b) shall have walls with a smooth impervious washable surface to a height of at least 1.8 metres;

(c) shall have floors of an impervious material;

(d) shall have window areas of one square metre for each 10 square metres of floor space, or be effectively air conditioned;

(e) shall be provided with artificial light.

[Regulation 20 amended in Gazette 18 Nov 1970 p. 3587; 3 May 1974 p. 1429.]

\section{Dining room insect protection}

The windows, doorways and other openings in the dining room shall be screened with a fine mesh or by some other physical means to exclude the ingress of flies and other insects.

[Regulation 21 amended in Gazette 18 Nov 1970 p. 3587.$]$

22. Tables

Every dining room - 
(a) shall have tables with a smooth impervious washable surface of a material other than lino; and

(b) shall have at least 610 millimetres of space at a dining table for every person it accommodates.

[Regulation 22 amended in Gazette 3 May 1974 p. 1429.]

\section{Sanitary and ablutionary facilities}

Every construction camp shall provide -

(a) for males -

(i) one closet to every 15 employees;

(ii) one urinal stall or 535 millimetres of urinal space at a urinal stall for every 20 employees;

(iii) one shower to every 15 employees; and

(iv) either one wash basin to every 15 employees or an equivalent trough with taps spaced 610 millimetres apart;

(b) for females -

(i) one closet to every 10 employees;

(ii) one shower to every 15 employees; and

(iii) either one wash basin to every 15 employees or an equivalent trough with taps spaced 610 millimetres apart.

[Regulation 23 amended in Gazette 3 May 1974 p. 1429.]

\section{Closets}

In every construction camp -

(a) closets shall be connected to the water carriage system of disposal wherever possible;

(b) where a closet is not connected to the water carriage system of disposal it shall he so constructed as to be completely fly proof. 


\section{Plumbing standards}

All plumbing fixtures and fittings at a construction camp shall be in accordance with the standards laid down in the by-laws made under the Country Towns Sewerage Act 1948.

\section{Laundry facilities}

(1) Unless industrial laundry facilities are provided, every construction camp shall be provided with washing units to the following scale:

Up to 100 persons - 1 unit to 10 persons.

Over 100 up to 200 persons - 1 unit to 12 persons.

Over 200 up to 300 persons -1 unit to 15 persons.

Over 300 up to 500 persons - 1 unit to 20 persons.

Over 500 persons -1 unit to 30 persons.

One washing unit consists of a copper and 2 troughs or a washing machine and one trough.

(2) Where a washing machine is provided it must be connected to a hot water supply or have its own element capable of heating the water.

(3) Clothes hoist or lines shall be provided in sufficient quantity to cater for the needs of the employees.

[Regulation 26 amended in Gazette 18 Nov 1970 p. 3587.]

\section{Water supply}

(1) A sufficient supply of potable water for drinking purposes shall be provided at every construction camp.

(2) All tanks and vessels used for the storage of drinking water shall be so constructed and covered as to prevent water stored therein from becoming polluted or contaminated. 


\section{Part III - Caravans used in construction camps}

\section{Definitions}

In this Part, unless the context otherwise requires -

ablutionary or sanitary caravan means a structure with either fixed or retractable wheels and axles, designed for use as an ablutionary or sanitary block, so constructed as to be movable by towing and used in a construction camp;

artificial light means light sufficient to illuminate the entire room at 54 lumens per square metre of general illumination, measured on a horizontal plane 915 millimetres above the floor;

construction camp means any camp used for a duration of more than 3 months though not necessarily in the one location, for the accommodation of a work force of more than 25 persons in conjunction with -

(a) the construction of a railway line or siding;

(b) the construction, structural alteration or demolition of -

(i) a building;

(ii) a dock, wharf, jetty, pier, breakwater, tunnel, dam, viaduct, reservoir, pipeline, gasholder; and

(iii) waterworks or sewerage works;

(c) the preparation of an area for mining operations; and

(d) any other work that requires a temporary resident work force,

but does not include -

(e) camps used for defence purposes; and

(f) wayside camps of drovers or teamsters;

dining caravan means a structure with either fixed or retractable wheels and axles, designed for use as a dining room, so constructed as to be movable by towing, and used in a construction camp; 
kitchen caravan means a structure with either fixed or retractable wheels and axles, designed for use as a kitchen, so constructed as to be movable by towing and used in a construction camp;

office caravan means a structure with either fixed or retractable wheels and axles, designed for use as an office, so constructed as to be movable by towing, and used in a construction camp;

residential caravan means a structure with either fixed or retractable wheels and axles, designed for use as a dwelling for human occupation, so constructed as to be movable by towing, and used in a construction camp;

sleeping caravan means a structure with either fixed or retractable wheels and axles, designed for use as sleeping compartments for human occupation, so constructed as to be movable by towing, and used in a construction camp;

toilet compartment means a compartment designed to accommodate a chemical closet or a water closet used in a construction camp.

[Regulation 28 erratum in Gazette 26 Jun 1970 p. 1845; amended in Gazette 3 May 1974 p. 1429.]

\section{Floor areas in residential caravans}

(1) Residential caravans shall have a floor area of not less than 7.4 square metres and the total floor area shall be ascertained from external measurements taken at a height of 460 millimetres above floor level.

(2) A floor area of 3.7 square metres per person shall be provided for each adult or child over 10 years of age.

(3) A floor area of 1.85 square metres shall be provided for each of the first 2 children under 10 years of age and 3.7 square metres each for any children under 10 years of age in excess of 2 .

[Regulation 29 amended in Gazette 16 Dec 1971 p. 5225; 3 May 1974 p. 1429.] 
30. Ceiling heights in residential caravans

The average ceiling height of a residential caravan shall not be less than 1.93 metres.

[Regulation 30 amended in Gazette 20 Apr 1971 p. 1189; 16 Dec 1971 p. 5225; 3 May 1974 p. 1429.]

31. Toilet compartments in relation to food preparation

A toilet compartment shall not open directly into that part of a caravan used for food preparation.

32. Separate sleeping compartments

(1) Except for married couples, de facto partners and children under 10 years of age, there shall be separate sleeping compartments for males and females.

(2) Every sleeping compartment for an adult shall be at least 1.9 metres in one plan dimension.

[Regulation 32 amended in Gazette 3 May 1974 p. 1429; 30 Jun 2003 p. 2598.]

33. Sleeping compartment dimensions

(1) The dimensions of each sleeping compartment shall be such that there is 5 cubic metres for each person intended to be accommodated therein.

(2) Each sleeping compartment shall have a locker or wardrobe for storage of clothes.

[Regulation 33 amended in Gazette 3 May 1974 p. 1429.]

34. Fly wire

The windows, doorways and other openings in dining and kitchen caravans shall be screened with fine mesh to exclude the ingress of flies and other insects. 
35. Dining caravans

Every dining caravan shall have -

(a) tables with a smooth impervious washable surface; and

(b) at least 560 millimetres of space at a dining table for every person it accommodates.

[Regulation 35 amended in Gazette 3 May 1974 p. 1429.$]$

\section{Kitchen caravans}

(1) Every kitchen caravan shall be equipped with -

(a) cooking facilities complying with regulation 44(d);

(b) a double bowl stainless steel sink for dish-washing;

(c) a handbasin supplied with hot and cold water, soap, nail-brush and disposable paper towels;

(d) food preparation tables or benches with a smooth impervious washable surface;

(e) adequate refrigeration storage for keeping perishable foods;

(f) a sufficient number of rubbish receptacles with a smooth impervious surface and tight fitting lid, for the reception of food scraps; and

(g) artificial light.

(2) Food in a kitchen caravan not being prepared and not in a refrigerator shall be kept in fly proof cupboards or containers.

\section{Office caravan}

In addition to office fittings, an office caravan may be fitted with a separate sleeping compartment complying with the requirements set out in regulation 33 .

\section{Ablutionary and sanitary caravans}

(1) Where no fixed ablutionary and sanitary facilities are provided in a construction camp, ablutionary and sanitary caravans shall be used. 
(2) Ablutionary and sanitary caravans shall be fitted with water closets or chemical closets, showers, and wash basins in accordance with the requirements of regulation 23 .

(3) All plumbing fixtures and fittings shall be in accordance with the standards laid down in the by-laws made under the Country Towns Sewerage Act 1948.

(4) Provision shall be made on the outlets of wash basins and showers for connection to an external method of liquid waste disposal.

[Regulation 38 amended in Gazette 18 Nov 1970 p. 3587.$]$

\section{Materials used in caravan construction}

(1) All materials used in the construction of a caravan to which these regulations apply shall be of a suitable nature and quality for the purposes for which they are used and the methods of using the materials shall be according to accepted practice in the trade.

(2) The materials used for the construction of the outer skin of a caravan used in a construction camp, shall not be inferior to those faces on which the effective spread of flames neither exceeds 305 millimetres during the first $1 \frac{1}{2} 2$ minutes, nor exceed 840 millimetres after 10 minutes.

[Regulation 39 amended in Gazette 3 May 1974 p. 1430.]

40. Internal linings

(1) In a caravan used in a construction camp, the requirements for internal linings adjacent to any appliance which gives off heat shall be in accordance with the following standards -

(a) for solid fuel appliances B.S. Code of Practice CP. 340;

(b) for butane or propane gas Australian Standard CB20-1971 S.A.A. L.P. Gas Code; and

(c) for electricity S.A.A. Code C.C.7.

(2) Linings not referred to in subregulation (1) shall be in accordance with the Code of Practice and linings outside the 
areas of the Code of Practice shall, when finished, have surfaces not inferior to that required for the outer skin by regulation 39 and finishes based on nitrocellulose shall not be used.

[Regulation 40 amended in Gazette 16 Dec 1971 p. 5225.]

\section{Design and construction}

A caravan used in a construction camp shall be so designed and constructed that -

(a) the structure shall be capable of sustaining and transmitting the dead load, imposed loads and horizontal and inclined forces to which it may be subjected in the service in which it is used;

(b) the external construction of the caravan shall adequately resist the penetration of weather and dampness;

(c) the external walls, roof and floor shall be of such materials and be so constructed, excluding glazed areas, that the thermal transmittance co-efficient to external surfaces is not more than 0.30 ;

(d) condensation on the surface of the inner walls and partitions is avoided without the necessity for lowering the inside temperature or increasing the ventilation beyond the levels required for health and comfort;

(e) every living compartment shall be provided with windows or skylights, the total area of which shall be not less than one-tenth the floor area of that compartment;

(f) the roof shall discharge rainwater clear of windows and doors;

(g) any fixed partitions separating sleeping compartments from other parts of the caravan together with hinged or sliding doors, shall for the purpose of obtaining some degree of fire protection, completely separate the 2 compartments between which they are used;

(h) each separate compartment (other than a toilet compartment, shall be provided with a satisfactory, means of escape by - 
(i) a door of not less than 560 millimetres clear opening;

(ii) an escape panel of not less than 0.4 square metre clear opening with sides of not less than 460 millimetres and with its lower edge preferably not more than 760 millimetres above floor level, but never more than 915 millimetres above floor level; or

(iii) a window which, gives direct access to the open air in the event of fire and top hinged windows shall open through at least $70^{\circ}$ and shall automatically stay full open until closed manually;

(i) where it is a residential caravan there shall be at least 2 access doors spaced well apart or one door and adequate escape hatches, the door or doors shall open outwards and be of not less than 560 millimetres clear opening and shall be on the near side of the caravan and be hinged to the front.

[Regulation 41 amended in Gazette 3 May 1974 p. 1429-30.]

\section{Artificial light}

Every caravan used in a construction camp shall have means of providing artificial light either by gas or electricity.

\section{Residential caravans}

Every residential caravan shall be equipped with -

(a) adequate cooking facilities;

(b) a fixed sink, the waste pipe of which shall discharge outside the caravan;

(c) an adequate food storage cupboard; and

(d) a refrigerator. 


\section{Internal equipment}

The installation of internal equipment in a caravan used in a construction camp shall where applicable comply with the following standards:

(a) Any electrical installations shall comply with S.A.A. Code No. C.C.7. - Wiring of Caravans and Caravan Parks.

(b) Any installation for the use of propane or butane gas shall comply with Australian Standard CB20-1971 S.A.A. L.P. Gas Code (1956).

(c) Light fittings shall comply with S.A.A. Code C.C.7. for electricity and Australian Standard CB20-1971 S.A.A. L.P. Gas Code for gas.

(d) Electrical cooking appliances shall comply with the S.A.A. Code No. C.C.7. - Wiring of Caravans and Caravan Parks and gas burning cooking appliances shall comply with Australian Standard CB20-1971 S.A.A. L.P. Gas Code.

(e) All appliances shall be heat insulated from any combustible part of the caravan in the manner required in the Australian Standard CB20-1971 S.A.A. L.P. Gas Code and a shield of non-combustible material shall be provided over the exposed vertical surface adjacent to the immediately above any hotplate to a height of not less than 305 millimetres and extending beyond the sides of the appliance to a distance of not less than 405 millimetres.

(f) Water heating appliances shall comply with Australian Standard CB20-1971 S.A.A. L.P. Gas Code for butane or propane gas S.A.A. Code C.C.7. for electricity and B.S. Code of Practice CP. 340 for solid fuel.

(g) Chemical closets shall comply with the requirements of British Standard 2081 - Portable closets for use with chemicals.

(h) Flushing water closets shall have provision on the pan outlet for connection to an external drainage system and 
shall be fed from a cold water storage cistern on the site distribution system via a flushing cistern complying with Metropolitan Water Board ${ }^{2}$ or Country Water Supply (Sewerage) Regulations.

(i) Boxed in compartments and cupboards shall be easily accessible for cleaning purposes.

[Regulation 44 amended in Gazette 16 Dec 1971 p. 5225; 3 May 1974 p. 1430.]

\section{Fixed ventilation}

Fixed ventilation shall be provided in caravans used in construction camps -

(a) at the base of cookers and hotplates to ensure complete combustion of the fuel;

(b) overhead, to remove products of combustion and cooking smells;

(c) in gas container lockers in accordance with the requirements of Australian Standard CB20-1971 S.A.A. L.P. Gas Code;

(d) in solid fuel fire installations in accordance with the requirements of B.S. Code of Practice CP. 340;

(e) in food storage cupboards and lockers equally at the bottom and the top, each vent having a nett minimum area of 450 square millimetres per cubic metre of interior volume, calculated on the open space when the vents are covered with a vermin proof shield and shelves shall be so designed as to permit the passage of a current of air from the bottom vent to the top one;

(f) in totally enclosed fold-away beds, to permit a flow of air, but vents should not communicate directly with the air outside the caravan;

(g) in wardrobes and bedlockers, to permit a flow of air from the bottom to the top, between ventilators, but vents should not communicate directly with the air outside the caravan; 
(h) in toilet compartments, at floor level near the chemical closet or water closet pan, and shall have not less than 2900 square millimetres effective opening.

[Regulation 45 amended in Gazette 16 Dec 1971 p. 5225; 3 May 1974 p. 1430.]

\section{Adjustable ventilation}

In addition to permanent ventilation, adjustable ventilation shall be installed, in caravans used in construction camps, either in the roof or at a high level, in small bedrooms, over cookers and hot plates and in the toilet compartment to cater for adverse conditions requiring windows to be shut.

\section{Part IV - Offences and penalties}

[Heading inserted in Gazette 14 Oct 1988 p. 4160.]

47. Offences and penalties

(1) A person who contravenes a provision of these regulations commits an offence and is liable to -

(a) a penalty which is not more than $\$ 1000$ and not less than -

(i) in the case of a first offence, $\$ 100$;

(ii) in the case of a second offence, \$200; and

(iii) in the case of a third or subsequent offence, $\$ 500$;

and

(b) if that offence is a continuing offence, a daily penalty which is not more than $\$ 100$ and not less than $\$ 50$.

[Regulation 47 inserted in Gazette 14 Oct 1988 p. 4160.$]$ 


\section{Notes}

1 This is a compilation of the Construction Camp Regulations and includes the amendments made by the other written laws referred to in the following table. The table also contains information about any reprint.

\section{Compilation table}

\begin{tabular}{|c|c|c|}
\hline Citation & Gazettal & Commencement \\
\hline Construction Camp Regulations & $\begin{array}{l}16 \text { Jun } 1970 \\
\text { p. } 1668-75\end{array}$ & 16 Jun 1970 \\
\hline Untitled regulations & $\begin{array}{l}18 \text { Nov } 1970 \\
\text { p. } 3586-7\end{array}$ & 18 Nov 1970 \\
\hline Untitled regulations & $\begin{array}{l}20 \text { Apr } 1971 \\
\text { p. } 1188-9\end{array}$ & 20 Apr 1971 \\
\hline Untitled regulations & $\begin{array}{l}16 \text { Dec } 1971 \\
\text { p. } 5225\end{array}$ & 16 Dec 1971 \\
\hline Untitled regulations & $\begin{array}{l}3 \text { May } 1974 \\
\text { p. } 1428-30\end{array}$ & 3 May 1974 \\
\hline Untitled Regulations & $\begin{array}{l}12 \text { Jul } 1974 \\
\text { p. } 2597\end{array}$ & 12 Jul 1974 \\
\hline
\end{tabular}

Reprint of the Construction Camp Regulations as at 11 Oct 1985 in Gazette

29 Oct 1985 p. 4167-82 (includes amendments listed above)

Health (Offences and Penalties)

14 Oct $1988 \quad 14$ Oct 1988

Amendment Regulations 1988 Pt. 2 p. 4160-3

Equality of Status Subsidiary $\quad 30$ Jun $2003 \quad 1$ Jul 2003 (see r. 2 and Gazette

Legislation Amendment

p. 2581-638 30 Jun 2003 p. 2579)

Regulations 2003 Pt. 8

Reprint 2: The Construction Camp Regulations as at 5 Dec 2003 (includes amendments listed above) (correction in Gazette 13 Jan 2004 p. 146)

2 Under the Metropolitan Water Authority Act 1982 s. 8, the Metropolitan Water Supply, Sewerage and Drainage Board was preserved and continued as the Metropolitan Water Authority. Under s. 12(1) of that Act the Authority was administered by a Board of management known as the 'Metropolitan Water Board'. Under the Acts Amendment and Repeal (Water Authorities) Act 1985 s. 36 the Metropolitan Water Authority became a component of the corporate identity of the Water Authority of Western Australia. Under the Water Agencies Restructure (Transitional and Consequential Provisions) Act 1995 certain references to the Water Authority were changed to references to the Water and Rivers Commission, the Coordinator of Water Services or the Water Corporation. 